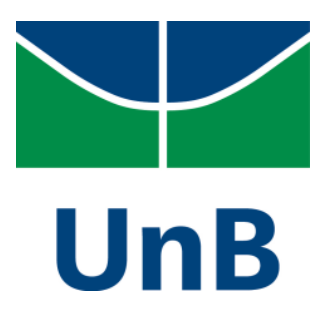

UNIVERSIDADE DE BRASÍLIA

FACULDADE DE COMUNICAÇÃO - FAC

PROGRAMA DE PÓS-GRADUAÇÃO

CURSO DE DOUTORADO

MANOEL HENRIQUE TAVARES MOREIRA

DO PARTIDARISMO À INFORMAÇÃO: AS MUDANÇAS ESTRUTURAIS NO JORNALISMO BRASILEIRO E A FORMAÇÃO DOS IMPÉRIOS MIDIÁTICOS 


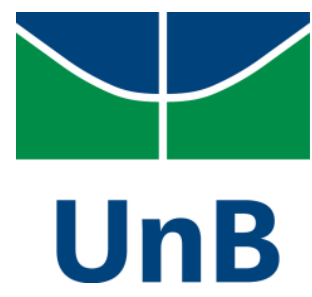

UNIVERSIDADE DE BRASÍLIA

FACULDADE DE COMUNICAÇÃO - FAC

PROGRAMA DE PÓS-GRADUAÇÃO

CURSO DE DOUTORADO

MANOEL HENRIQUE TAVARES MOREIRA

\section{DO PARTIDARISMO À INFORMAÇÃO: AS MUDANÇAS ESTRUTURAIS NO JORNALISMO BRASILEIRO E A FORMAÇÃO DOS IMPÉRIOS MIDIÁTICOS}

Tese apresentada ao Programa de Pós-Graduação em Comunicação da Universidade de Brasília (UnB) como requisito parcial para a obtenção do Título de Doutor em Comunicação.

Orientador: Prof. Dr. Luiz Martins da Silva 


\title{
DO PARTIDARISMO À INFORMAÇÃO: AS MUDANÇAS ESTRUTURAIS NO JORNALISMO BRASILEIRO E A FORMAÇÃO DOS IMPÉRIOS MIDIÁTICOS
}

Tese apresentada ao Programa de Pós-Graduação em Comunicação da Universidade de Brasília (UnB) como requisito parcial para a obtenção do Título de Doutor em Comunicação.

Orientador: Prof. Dr. Luiz Martins da Silva

Aprovado em

\author{
Prof $^{a}$. Dr ${ }^{a}$. Dione Oliveira Moura \\ MEMBRO \\ $\overline{\text { Prof. Dr. Fábio Henrique Pereira }}$ \\ MEMBRO \\ Prof. Dr. Luiz Martins da Silva. \\ ORIENTADOR

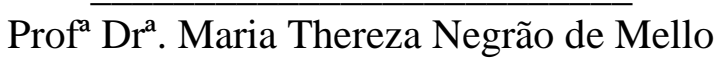 \\ MEMBRO EXTERNO \\ Prof. Dr. Sérgio Euclides Braga Leal de Sousa \\ MEMBRO EXTERNO
}


Aos cinquenta e sete anos que vivi, por terem me ensinado o que realmente importa: o abraço sincero de um amigo; o sorriso confiante de um filho; e o fogo no olhar de quem amamos. 


\section{AGRADECIMENTO}

É impossível dedicar-se ao longo de quatro anos a um trabalho de pesquisa acadêmica, com a dimensão de uma tese de doutorado, sem contar com o apoio, a compreensão e a cumplicidade de quem amamos.

Os momentos de ausência, o isolamento necessário à reflexão e a absurda fixação em levar adiante o projeto podem provocar naqueles que nos rodeiam uma sensação de que os abandonamos e de que não estamos mais disponíveis.

Peço desculpas àqueles que amo por tê-los feito passar por tudo isso. $E$ agradeço, sinceramente, pois não me faltaram apoio, incentivo, compreensão e, principalmente, amor.

Ao meu orientador e amigo, Prof. Dr. Luiz Martins da Silva, com quem convivo há tanto tempo e que tão generosamente partilhou comigo seu imenso conhecimento e seus inabaláveis valores a respeito do nosso campo profissional. Exemplo que vou guardar para sempre.

Aos meus filhos maravilhosos, orgulho maior da minha vida: Felipe (jornalista competente, sério e obstinado), Lucas (publicitário criativo, comprometido e íntegro) e Gabriel (Bielzinho), o pré-adolescente mais inquieto e perspicaz que conheço, todo o meu amor e a minha expectativa de poder inspirá-los a buscar seus sonhos e encontrar a felicidade.

Um sofrido e especial agradecimento à memória da minha mãe (Tunica), cujo sonho maior era me ver doutor. Pois é mãe, registro aqui a minha gratidão por ter me feito acreditar que nada é impossível, quando temos coragem e determinação. Pena você não estar aqui!

E um último e muito especial agradecimento àquela a quem conheci no $2^{\circ}$ semestre da graduação, há mais de 32 anos, muito jovem, mas de personalidade forte e cativante. Com quem partilhei momentos gloriosos, intensos, de profunda alegria e de imensa tristeza e que se constituiu no maior incentivo para que eu alcançasse todos os meus sonhos. A você, Valéria, meu agradecimento e meu eterno amor. 
The natural history of the press is a history of surviving species. 


\section{SUMÁRIO}

RESUMO

ABSTRACT

RESUMEN

INTRODUÇÃO

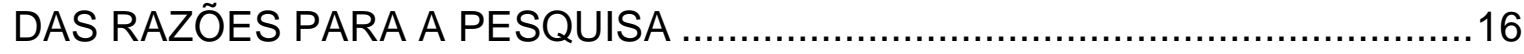

DOS PRESSUPOSTOS TEÓRICO-METODOLÓGICOS QUE NORTEIAM A

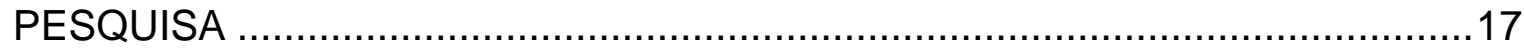

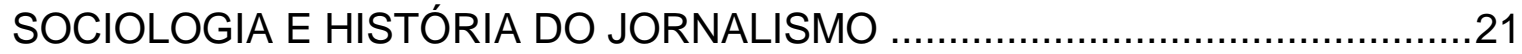

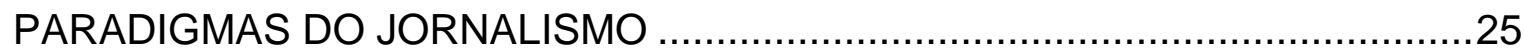

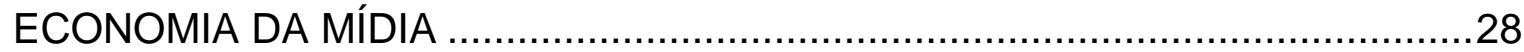

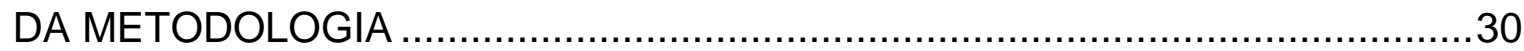

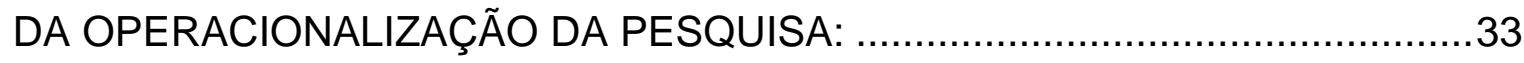

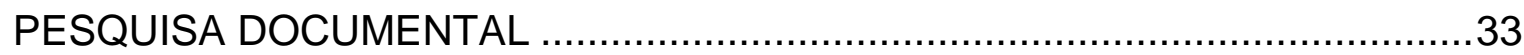

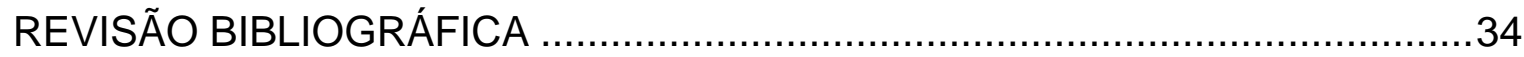

ANÁLISE DE CONTEÚDO .........................ERRO! INDICADOR NÃO DEFINIDO.

CAPÍTULO I - ACORRENTADA, DESBOCADA, APAIXONADA: ASSIM NASCE A

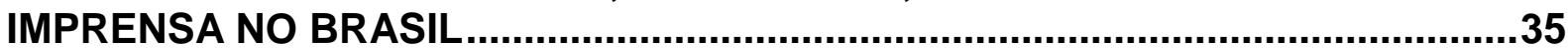

1.1 DE COMO UM PRÍNCIPE INDECISO ACABA POR ENGANAR NAPOLEÃO.

1.2 HIPÓLITO E O CORREIO BRAZILIENSE/ARMAZÉM LITERÁRIO ..............41

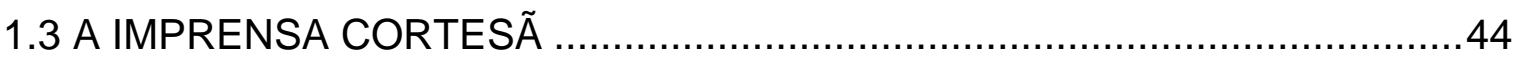

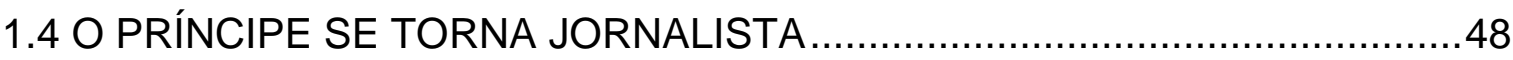

1.5 NA GUERRA PELA INDEPENDÊNCIA O JORNAL SE TRANSFORMA EM

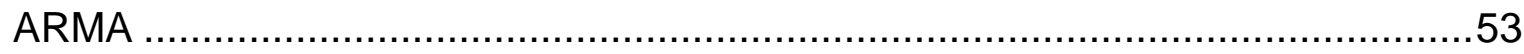

1.6 SEM O IMPERADOR O BRASIL AVANÇA E O JORNALISMO ENTRA EM

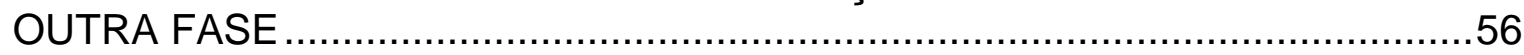

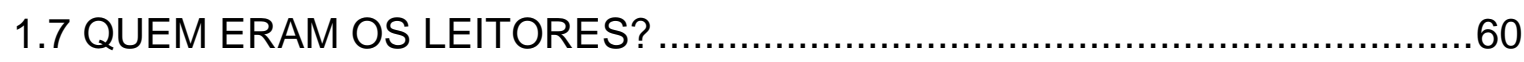

1.8 O REGIME CAI, MAS TODO O RESTO PERMANECE .............................65

CAPÍTULO II - DA SUBVENÇÃO AO LUCRO: A IMPRENSA TROCA A POLÍTICA PELO MERCADO E O JORNALISMO NORTE-AMERICANO É O MODELO..........70

2.1 O JORNALISMO NORTE-AMERICANO ………....................................76

2.2 ENTRAM EM CENA O REPÓRTER E A NOTÍCIA......................................78

2.3 A IMPRENSA AMERICANA SE TORNA MODELO PARA O JORNALISMO

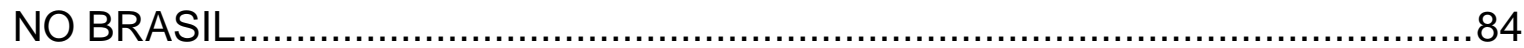

CAPÍTULO III - O BRASIL MUDA. E, COM ELE, MUDA O JORNALISMO .............92 
3.1 SÃO MUITAS AS MUDANÇAS E A REPERCUSSÃO NA IMPRENSA É IMEDIATA. .96

3.2 MUDAM OS JORNALISTAS .98

3.2.1 A Associação Brasileira de Imprensa e a construção da identidade profissional dos jornalistas brasileiros 104

3.2.2 O Sindicalismo Entre Os "Proletários Intelectuais" 109

3.2.3 A implantação dos cursos superiores de Jornalismo no Brasil. 111

3.3 AS ONDAS DO RÁDIO DEMOCRATIZAM A INFORMAÇÃO E AMPLIAM O ALCANCE DO JORNALISMO ……...........................................................118

CAPÍTULO IV - IMPÉRIO: UMA PALAVRA, MUITOS SIGNIFICADOS .................127

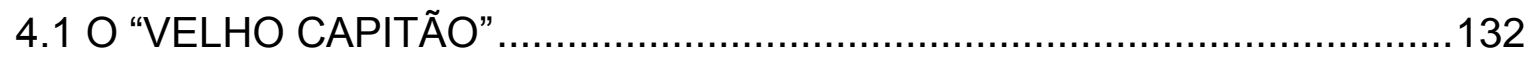

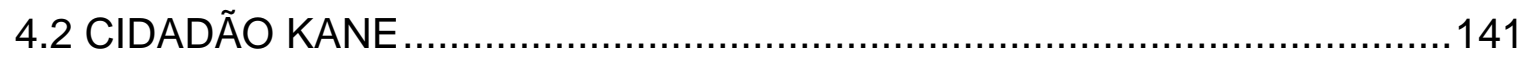

CAPÍTULO V - A TRANSIÇÃO SE COMPLETA OU NÃO ..................................153

5.1 AS EMPRESAS JORNALÍSTICAS BRASILEIRAS NESSE PERÍODO DE

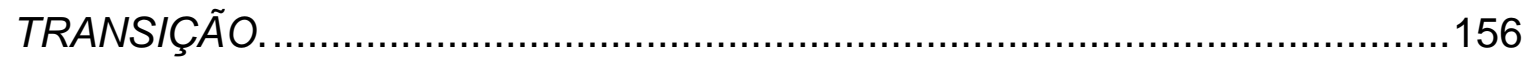

5.2 O PROFISSIONAL DO JORNALISMO DAQUELE PERÍODO. ...................156

5.3 A CONSTRUÇÃO DO DISCURSO JORNALÍSTICO.................................156

5.4 A AÇÃO EMPRESARIAL DOS PROPRIETÁRIOS DE EMPRESAS

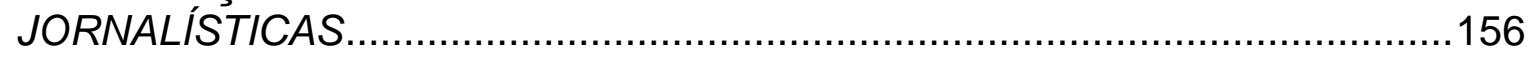

5.5 TIPIFICAÇÃO DAS AÇÕES SOCIAIS PRESENTES NA ATIVIDADE JORNALÍSTICA DURANTE A TRANSIÇÃO - TABELA 2 ...............................158

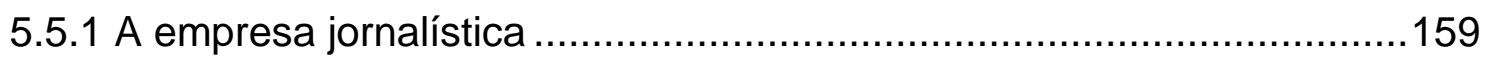

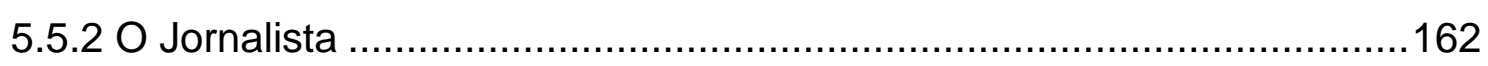

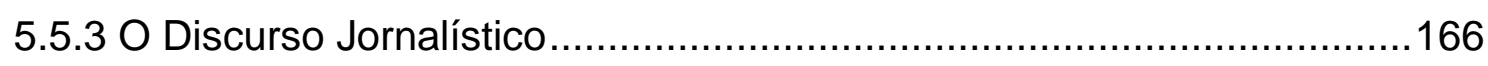

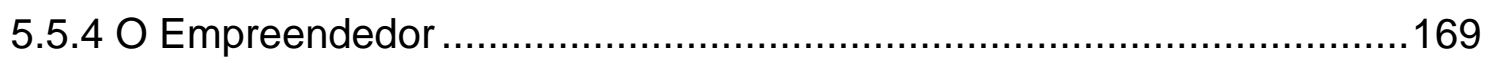

5.6 CONSEQUÊNCIAS DESSAS MUDANÇAS ...........................................170

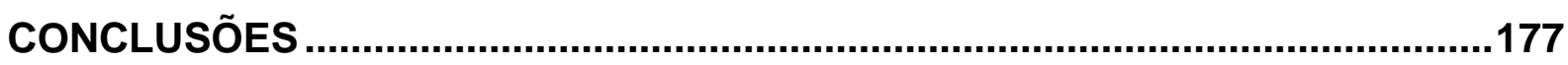

BIBLIOGRAFIA

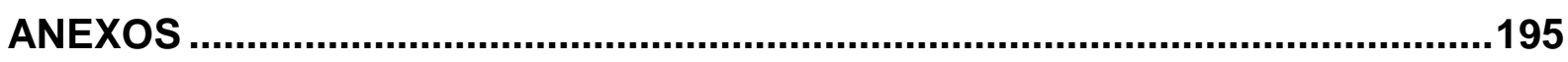

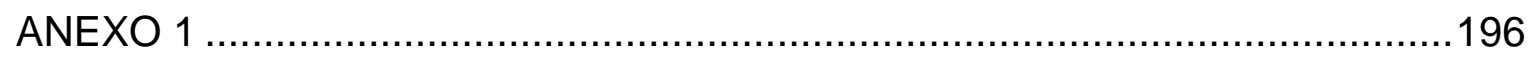

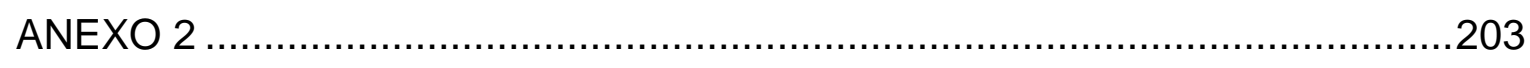

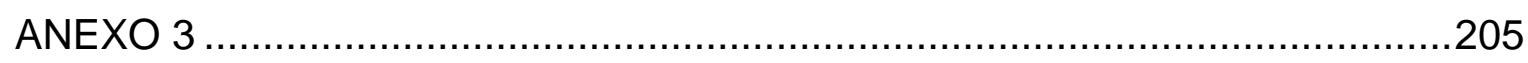

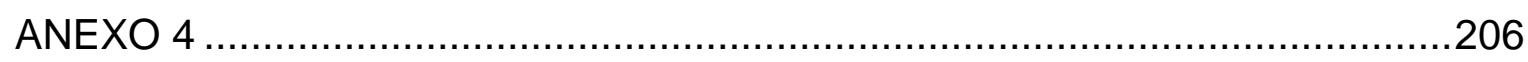

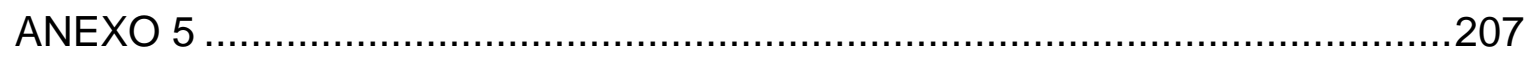

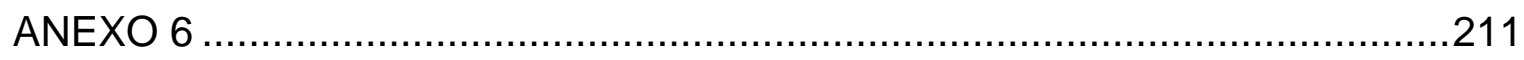




\section{RESUMO}

O que se buscou com esta tese foi analisar os fatores históricos, técnicos, econômicos, sociais e políticos que promoveram transformações importantes na atividade jornalística, aqui denominadas mudanças estruturais, presentes na transição do jornalismo partidário para o jornalismo comercial no Brasil. Essas mudanças acabaram por gerar as condições necessárias ao surgimento de empresas jornalísticas economicamente viáveis, que por sua vez respondem, do ponto de vista histórico, pela criação de grandes conglomerados midiáticos no País, na primeira metade do século XX. Com isso, pretendeu-se compreender de que maneira 0 jornalismo brasileiro evoluiu de atividade subordinada a forças políticas para empreendimento de caráter empresarial, cuja referência, nesse caso, são os dois primeiros conglomerados midiáticos brasileiros: os Diários Associados, comandados por Assis Chateaubriand e o Grupo Globo, de Roberto Marinho.

Palavras-chave: Jornalismo, História do Jornalismo, Impérios Midiáticos, Tipos Ideais, Weber, Mudanças Estruturais 


\begin{abstract}
What was sought with this thesis was to analyze the historical, technical, economic, social and political factors that promoted important changes in journalism, here termed structural changes, present in the transition from partisan journalism for commercial journalism in Brazil. These changes have generated the conditions for the emergence of economically viable newspaper companies, which account for, from a historical point of view, the creation of large media conglomerates in the country in the first half of the twentieth century. Thus, we intended to understand how the Brazilian journalism evolved from an activity subject to political forces to commercial enterprise, the reference in this case are the first two Brazilian media conglomerates: the Diários Associados, led by Assis Chateaubriand and the Roberto Marinho's Grupo Globo.
\end{abstract}

Keywords: Journalism, History of Journalism, Media Empires, Ideal Types, Weber, Structural Changes 


\section{RESUMEN}

Lo que se buscaba con esta tesis era analizar los factores históricos, técnicos, económicos, sociales y políticos que promovieron cambios importantes en el periodismo, aquí llamados cambios estructurales, vigentes en la transición del periodismo partidista para el periodismo comercial en Brasil. Estos cambios han generado las condiciones necesarias para la aparición de las compañías de periódicos económicamente viables, que a su vez representan, desde un punto de vista histórico, la creación de grandes conglomerados de medios en el país en la primera mitad del siglo XX. Nuestra intención era entender cómo el periodismo brasileño evolucionó de actividad subordinada a las fuerzas políticas a iniciativas de carácter empresarial, cuyas referencias, en este caso, son los dos primeros conglomerados de medios brasileños: Os Diários Associados, liderados por Assis Chateaubriand y el Grupo Globo, de Roberto Marinho .

Palabras clave: Periodismo, Historia del Periodismo, los Imperios de Medios de Comunicación, Tipos Ideales, Weber, Cambios Estruturales 


\section{INTRODUÇÃO}

Ao longo dos últimos duzentos anos ${ }^{1}$, o jornalismo brasileiro inseriu-se como instância fundamental na construção das instituições, da identidade e do caráter nacional. Apesar desse importante papel, o conhecimento que temos da história do jornalismo no Brasil ainda é escasso e, em grande parte, esforço dos próprios jornalistas, interessados em desvendar as origens e o processo de construção de seu campo profissional.

As pesquisas nessa área invariavelmente têm como objeto a trajetória de veículos de comunicação ou de personagens marcantes do universo midiático. Biografias e relatos de experiências pessoais são uma constante, uma espécie de "historiografia positiva e événementielle", conforme descrita por F. Simiand e P. Lacombe, apoiada em fatos, heróis, grandes personagens, objetos históricos "naturalizados". (SCHWARCZ, 2002:12)

Por reconhecer o valor do jornalismo como prática social, consideramos que tais abordagens não dão conta da sua dimensão e importância na construção de nossas instituições e dos valores que nos distinguem como Nação. Por este motivo, tratamos de buscar uma forma de nos apropriarmos da história do jornalismo brasileiro de uma maneira que nos permita contemplar as "Mudanças Estruturais" responsáveis pelas transformações a que esteve submetido ao longo desse período e assim poder estabelecer, com mais propriedade, sua importância e seu alcance.

A chave para chegar a este objetivo, no nosso ponto de vista, está na identificação e na análise das mudanças que o jornalismo experimentou, principalmente nas suas condições de produção, no perfil de seus profissionais e nas diversas formas de relacionamento que manteve com os públicos, ou seja, a partir das alterações que afetaram os seus diferentes aspectos e a maneira como foi praticado ao longo de todo esse tempo. Enfim, registrando e entendendo as chamadas "mudanças estruturais", conforme definido por ADGHIRNI e PEREIRA (2011:38).

\footnotetext{
${ }^{1}$ É possível identificar os momentos mais marcantes dessa trajetória na infografia "Linha do Tempo" construída pelo autor, constante do Anexo 6.
} 
Utilizando essa abordagem, tratamos então de identificar tais mudanças na trajetória experimentada pelo jornalismo brasileiro, em especial aquelas que ocorreram a partir do final do século XIX, momento em que surgem as condições necessárias para que, já na segunda metade do século seguinte, a atividade jornalística ampliasse sua presença e sua influência na nossa sociedade.

Para perceber mudanças estruturais presentes no jornalismo é preciso, de antemão, considerá-lo como uma prática social em constante processo de reinvenção.

O jornalismo é parte da sociedade. Ele é (re)construído a partir da participação contínua de diferentes atores sociais (indivíduos, instituições, conceitos e abstrações etc.) que interagem conforme um conjunto de normas e convenções responsáveis pela coordenação das atividades vinculadas a essa prática (PEREIRA apud ADGHIRNI, 2011:41)

Ao estudarmos a história da imprensa brasileira nessa perspectiva percebemos que uma das mudanças mais importantes observadas ao longo dos últimos dois séculos diz respeito à transição do jornalismo político (característico do início século XIX) para o jornalismo comercial (ou de informação ${ }^{2}$ ), que se firma a partir da primeira metade do século XX e que vai culminar com o surgimento dos primeiros conglomerados midiáticos no país.

Entendemos que isso só foi possível a partir do momento em que as empresas jornalísticas implantaram modelos discursivos, de produção e de gestão marcados por uma visão mercadológica. É o caso, por exemplo, da introdução da reportagem e da cobertura de temas que dizem respeito à rotina dos cidadãos ou dotados de interesse humano, como crimes e assassinatos, e a profissionalização das redações.

A partir daí, os jornais desenvolveram a capacidade de eleger os temas relevantes do debate público (agendamento), deixando de lado o papel de

\footnotetext{
${ }^{2}$ Conforme registra ADGHIRNI (2011:43), Charron e Bonville descrevem quatro modelos de jornalismo que se sucedem ao longo do tempo e que levam em consideração sua relação com a sociedade. São eles: 1 . Jornalismo de transmissão (século XVII): transmite informações das fontes diretamente ao seu público; 2 . Jornalismo de opinião (início do século XIX): coloca-se a serviço das lutas políticas; 3 . Jornalismo de informação (fim do século XIX): segue o modelo de coleta de notícias sobre a atualidade; e 4. Jornalismo de comunicação (décadas de 1970/1980): diversificação e subordinação da oferta a partir das preferências do público alvo.
} 
instrumentos político-partidários para assumir, definitivamente, a condição de protagonistas numa sociedade midiatizada. $O$ interessante é que os grandes conglomerados midiáticos, que surgem como evolução natural desse jornalismo comercial (ou de informação), vão alterar, definitivamente, não só a maneira de construir a notícia, como também passarão a interferir em outros setores da indústria cultural, respondendo por mudanças significativas na política, na arte e no entretenimento.

Para entender o alcance dessas mudanças e permanências é preciso "analisar e tipificar" os mecanismos de transformação da prática jornalística. É o que sugerem Brin, Charron e Bonville (2004). Eles utilizam o método do tipo ideal weberiano e lançam mão do conceito de paradigma, utilizado por Thomas Khun, definindo paradigma jornalístico como sendo "um sistema de regras coerentes com essa prática, com alto grau de compatibilidade, que são utilizadas consensualmente pelos participantes" (Ibidem:41).

Dentro dessa perspectiva, que permite entender as mudanças estruturais no jornalismo, é que vamos descrever (historicamente) e analisar (criticamente) a transição do jornalismo político para o jornalismo comercial e o consequente surgimento de grandes conglomerados midiáticos no Brasil, bem como as principais mudanças que eles provocaram no campo jornalístico.

Embora tardio em relação à América do Norte e à Europa, o processo de transformação experimentado pelo jornalismo brasileiro entre o final do século XIX e o início do século XX foi marcado por profundas alterações, não só de caráter técnico, mas, principalmente, em seus modelos de gestão e no alcance que passa a desfrutar junto à sociedade.

Em busca de sustentação econômica, o jornalismo no Brasil descobre, a partir daquele momento, o homem comum, o cidadão envolvido com os problemas de seu cotidiano: ruas esburacadas, transporte público deficiente, doenças e epidemias sem controle.

[...] estava em curso uma verdadeira revolução no modo de conceber e produzir jornais, que, iniciada na América do Norte e nos países mais influentes da Europa ocidental, principalmente a Grã-Bretanha, aportaria no Brasil nos últimos anos do século XIX (CARVALHO, 2013:39). 
Esse novo leitor era basicamente um curioso. Tinha interesse em saber das novidades científicas, dos avanços da tecnologia, dos confortos da vida moderna e, ao mesmo tempo, queria se inteirar dos detalhes mórbidos dos crimes violentos, dos assassinatos e dos desencontros passionais.

Naquele momento fica evidente que para ganhar dinheiro com o jornalismo era preciso, a exemplo do que ocorrera nos países centrais, afastá-lo da luta político-partidária, usar uma linguagem mais acessível e, antes de tudo, saciar a curiosidade do público. Era preciso, ainda, investir na rápida evolução da tecnologia para melhorar o processo de produção, aumentar as tiragens e ampliar os lucros.

Diante desse desafio, tornou-se imperioso aperfeiçoar os processos gerenciais, dar aos veículos uma organização que até então desconheciam, o que incluía a profissionalização da atividade, criando um quadro fixo de funcionários, promovendo a divisão e a especialização das tarefas nas redações.

Dividindo esquematicamente a empresa em variados setores, o Jornal do Brasil separa, na sua estrutura administrativa, a redação da administração geral e das oficinas. É composto das seguintes seções: a redação; as seções técnicas, onde estão a composição, a paginação, as máquinas, as oficinas de obras, a estereotipia, a fotogravura, a fotozincografia, a galvonoplastia, a encadernação e a eletricidade; e os demais serviços que englobam a revisão, a expedição, o almoxarifado e o correio. Na parte administrativa ficam a caixa, a contabilidade, a escrituração geral e as especiais, o recebimento dos anúncios e das assinaturas, o expediente do interior e do estrangeiro e o serviço especial da Revista da Semana, a partir de 1900 (BARBOSA, 2000:34).

Só assim foi possível atrair um público cada vez maior, formado em sua maioria por funcionários públicos, empregados do comércio, operários e outros integrantes das camadas populares dos centros urbanos mais importantes do País, que passam a buscar avidamente nos jornais as notícias que irão comentar nos bondes e nos cafés.

O narrador das crônicas de Amadeu Amaral, Memorial de um passageiro de bonde, Felício Trancoso, um conceituado chefe de repartição, embora prometa deixar o hábito de ler no bonde, "hábito estúpido [já que] ver o homem viver é mais interessante do que as histórias do que ele faz e pensa (ou pensa que pensa)" está sempre ocupado com a leitura de um diário da manhã ou com uma folha da tarde (AMARAL apud CRUZ, 2000:145).

Contribuem, ainda, para essa ampliação do interesse pelos jornais as mudanças técnicas introduzidas ao longo das últimas duas décadas do século XIX. São adquiridas novas e modernas máquinas de composição, novas impressoras que 
permitem melhorar a qualidade das ilustrações e o aumento da velocidade de impressão, ampliando consideravelmente as tiragens.

Do ponto de vista editorial, essas alterações foram, também, bastante significativas, com a valorização da imagem (ilustrações e fotografias), da diagramação, a introdução de entrevistas, da divisão do espaço editorial em seções e da redução da importância do "artigo de fundo", deslocado da primeira página para o interior da edição.

Foi a partir dessas mudanças sociais, técnicas e profissionais que surgiram no Brasil as condições essenciais para a implantação de um jornalismo economicamente viável, organizado em bases empresariais, com uma maior independência em relação ao poder político e que viria dar origem aos primeiros conglomerados de mídia no Brasil: os Diários Associados ${ }^{3}$ e o Grupo Globo ${ }^{4}$.

Segundo um relatório da consultoria ZenithOptimedia ${ }^{5}$, publicado em 2015, o Brasil é, atualmente, o 5 maior mercado publicitário do mundo, no qual foram investidos, apenas em 2014, U\$ 22 bilhões. Somente esses dois grupos faturaram, em 2013, mais de $R \$ 15$ bilhões e empregaram cerca de vinte e oito mil pessoas.

São números expressivos que demonstram a importância e o alcance dessas empresas, cuja atuação vai muito além da divulgação de notícias, respondendo por boa parte da produção cultural e artística do país, o que as tornam objeto de pesquisa recorrente para estudiosos do campo da comunicação.

Acreditamos que tais condições se adequam plenamente à escolha dessas empresas como referência da presente pesquisa, que tem como um dos seus objetivos compreender de que forma tais empreendimentos jornalísticos, criados a partir de capital nacional, superaram todas as dificuldades impostas pelo ambiente

\footnotetext{
${ }^{3}$ A escolha dos Diários Associados como exemplo de conglomerado midiático se deu, obviamente, por sua importância histórica, uma vez que esse grupo midiático já não tem a mesma importância econômica que experimentava na primeira metade do século XIX.

${ }^{4}$ A partir de 25/08/2014, as até então Organizações Globo passaram a denominar-se Grupo Globo. Fazem parte do grupo empresas como a Editora Globo, a Rede Globo de Televisão, a Globosat e a Infoglobo.

${ }^{5}$ ZenithOptmedia - Grupo empresarial, com sede em Londres e com escritórios em 72 países, especializado na auditagem e medição de investimentos em publicidade e marketing.
} 
empresarial e político brasileiro, ao longo de todo o século $X X$, para constituir-se no que hoje representam, em termos de formação de opinião e de influência política.

\section{DAS RAZÕES PARA A PESQUISA}

O avanço do conhecimento, na visão de Max Weber, corresponde a "um processo de desencantamento, realizado ao longo dos milênios da civilização ocidental" (WEBER, 2011:30). E é por meio desse "desencantamento" que se torna possível estabelecer, com segurança, a dimensão e o alcance dos mais diferentes fenômenos, aí incluídos os relacionados ao homem em sua ação sobre a natureza, bem como ao seu comportamento ou ao seu domínio sobre outros homens.

As transformações observadas no jornalismo brasileiro a partir do final do século XIX e o surgimento de dois grandes conglomerados midiáticos no Brasil compõem, sem dúvida, um tema relevante e que merece ser investigado por nos oferecer a oportunidade de compreender de que maneira a transformação do jornalismo repercute na transformação da própria sociedade e vice-versa.

Conhecer melhor a trajetória histórica dessas empresas de comunicação e de como foram capazes de interferir nos mais diferentes aspectos que nos distinguem como sociedade, desde a literatura, passando pela atividade política e pelo fortalecimento dos traços mais marcantes de nossa cultura (como a música popular, o cinema e a televisão) terá, certamente, um impacto positivo na pesquisa comunicacional, destacando um objeto de estudo para a Comunicação cuja percepção aumentará na medida em que esse objeto for "desnaturalizado" com a ajuda de uma análise histórico-sociológica.

É possível, ainda, perceber a importância desse trabalho pela escolha do autor em apoiar-se numa visão sociocêntrica da comunicação midiática, o que sem dúvida representa certa sofisticação para esse campo, pois amplia o interesse pela ação dos veículos jornalísticos para além de suas características formais, o que diverge da tendência que hoje prevalece nos estudos comunicacionais no Brasil.

Tomando como referência a trajetória histórica das empresas jornalísticas brasileiras, suas ações nos campos político e econômico e seus produtos jornalísticos, pretendemos, especificamente, contribuir para ampliar a percepção 
geral de como são complexas as condições sociais em que o jornalismo é produzido.

Igualmente, buscamos compreender como essas condições impactaram a implantação de um jornalismo de informação no Brasil que, em tese, faria avançar as instituições e aperfeiçoar a nossa sociedade, mas, que na verdade, em diversos momentos, teria optado pelo conservadorismo e pela legitimação de ações políticas responsáveis por ampliar os problemas e dificuldades enfrentadas pelos brasileiros.

Quanto ao seu valor social, a pesquisa buscou desvendar a maneira pela qual o jornalismo no Brasil abandona, em grande parte, suas características políticas em direção ao um jornalismo de informação, movimento essencial para o aperfeiçoamento não só do campo do jornalismo, mas de toda a sociedade. E nos levou, ainda, a entender como as grandes empresas de mídia brasileiras construíram suas estruturas e se consolidaram, estabeleceram alianças e compromissos no campo político e apontar algumas das "características fundamentais do setor, como a sua grande concentração, sua ampla e contínua expansão, o que inclui ramificações regionais e locais, e a influência que exercem na elaboração de políticas públicas para o setor" (CABRAL, 2009).

Com isso, podemos antecipar que se ampliou a compreensão do papel social desempenhado pelos veículos de comunicação, das pressões a que estão submetidos, das condições de produção do jornalismo e o impacto que essas condições produzem sobre o ambiente político e econômico.

DOS PRESSUPOSTOS TEÓRICO-METODOLÓGICOS QUE NORTEIAM A PESQUISA

A tradição da pesquisa em Comunicação tem se apoiado, ao longo de mais de um século, em diversas disciplinas ligadas às Ciências Sociais, como a Sociologia, a Psicologia e a Antropologia; relacionadas às Ciências Naturais, como a Biologia e a Física; à Matemática; às Ciências da Linguagem (Linguística e Semiótica) e a outras áreas do conhecimento. Com isso, virou lugar comum afirmar que a Comunicação constitui-se num saber interdisciplinar, ou seja, situa-se como uma "ciência encruzilhada" (MARTINO, 2006:39). 
Mesmo com essa diversidade de abordagens (ou, quem sabe, até por causa dela), a definição de um objeto específico da Comunicação encontra resistências. As diferentes aproximações utilizadas pelos teóricos na tentativa de definir um campo comunicacional esbarram, invariavelmente, na falta de um objeto de estudo com características específicas ligadas à Comunicação.

O termo "comunicação" é consensualmente aplicado ao ato de estabelecer uma relação, seja entre organismos vivos, entre objetos ou entre seres humanos. Apesar de haver uma tradição de estudos relacionados à Comunicação, que remonta ao final do século XIX, contemplando desde uma visão generalizada do fenômeno comunicacional até a troca simbólica entre seres humanos, foi com os estudos relacionados ao surgimento da sociedade de massa que o campo teórico da Comunicação avançou na sua tentativa de definir uma epistemologia própria.

Com isso, a pesquisa em Comunicação acabou por eleger a comunicação midiática (aquela em que há a intervenção de um meio tecnológico) como a que tem a melhor possibilidade de vir a se constituir no objeto de estudo específico da Comunicação. Isso colocou os meios de comunicação no centro das atenções dos pesquisadores, que passaram a analisar suas características, seus efeitos, sua organização e o seu alcance.

Essa tendência é denominada midiacêntrica (ou seja, centrada no estudo da mídia) e estuda o impacto que a Comunicação tem sobre a sociedade quando dissemina uma "visão de mundo" autoritária, cujas referências mais importantes são a cultura do campo profissional e institucional e as exigências do mercado (MOTTA, 2005:62).

Como foco dos estudos que podem vir a constituir a Comunicação como disciplina, os veículos de comunicação têm sido analisados a partir de muitos aspectos, como registra Mauro Wolf: "regulamentações legislativas (...); intrincadas operações financeiras (...); episódios retumbantes acerca da não realização de um programa considerado 'incômodo'; crises, quedas e triunfos” (WOLF, 2001:13).

Por outro lado, esses meios foram pouco estudados a partir de uma perspectiva histórica, principalmente no que concerne à sua institucionalização, aos aspectos econômicos e políticos que permitiram que avançassem e assumissem o 
papel de elementos centrais dessa sociedade complexa também chamada de sociedade midiática.

Ou seja, estudos dessa natureza constituem-se na outra face da moeda do midiacentrismo e são descritos como pertencentes ao paradigma sociocêntrico, caracterizado por considerar importantes o poder do jornalismo e o espaço privilegiado que ele ocupa em termos de socialização. Nesse sentido, constitui-se numa abordagem suscetível às contradições sociais e sujeita a inúmeras pressões por parte da sociedade civil (MOTTA, 2005:63).

Para atribuir a uma teoria o estatuto de conhecimento científico, justificado e validado, o enunciado que o representa deve permitir uma análise lógica, passível de reproduzir as condições em que foi produzido, distinguindo-o do senso comum.

Encontramos na história os traços recorrentes de um dado fenômeno, o que a legitima como uma forma de conhecimento capaz de ordenar e dar sentido aos eventos, relacionando-os criticamente a partir de suas circunstâncias sócio-culturais, permitindo constituir um enlace entre o indivíduo e o contexto social.

Mas é preciso levar em consideração que a cientificidade da prática histórica está diretamente relacionada ao método utilizado, de forma a "que participe das características da ciência e se adapte, mediante um trabalho teórico rico e suficiente, às peculiaridades de seu objeto" (ARÓSTEGUI, 2006:77).

De maneira similar ao que ocorre nas demais disciplinas ligadas às ciências sociais, o uso de métodos de pesquisa em história permite ao pesquisador partir de opções teóricas as mais diversas, o que determina uma multiplicidade de construção de modelos e de concepções distintas do conhecimento histórico (FONTES, 1997:359).

Um bom exemplo de método de análise que concebe o real como um processo histórico é o chamado método dialético, desenvolvido por Marx a partir de uma interpretação materialista da história, que atribui valor à gênese da sociedade, sua formação e sua atuação em função dessa origem histórica.

De acordo com a visão de Karl Marx, expressa no seu clássico "A Ideologia Alemã", escrito em coautoria com Friedrich Engels e publicado originalmente em 
1932, a gênese histórica está na capacidade do homem de atender às necessidades básicas, ou seja, prover as condições materiais necessárias à vida. Uma vez satisfeitas as necessidades primárias, ao produzir novas necessidades o homem estabelece o primeiro ato histórico.

Essa construção histórica do homem a partir de sua produção material, de sua dependência mútua, resultante de suas necessidades e de suas condições de produção, permite uma visão verdadeira da trajetória humana, livre dos dogmas religiosos e do que Marx e Engels chamam de "absurdos políticos".

O campo da pesquisa histórica se utiliza, ainda, em sua elaboração de outros elementos cognitivos que contribuem para o desenvolvimento de modelos baseados em pressupostos teóricos de diversos outros campos das ciências sociais, como o conceito de tipo ideal, de Max Weber, o funcionalismo e o estruturalismo.

Com isso, fica claro que o método histórico tem características que coincidem, na essência, com os métodos utilizados por outras ciências, mas é preciso levar em conta que existe uma característica única que deve ser considerada pelo historiador: não há observação direta da realidade, pois essa está confinada em um dado momento, no passado, e se apresenta ao pesquisador por meio de indícios, pistas, objetos, relatos escritos ou orais, vestígios.

E há, ainda, outro elemento que torna ainda mais complexa a observação: nenhum desses elementos indiciários são "realidades espontâneas". Na verdade, eles estão impregnados de motivações. Não há informação neutra, despojada de interesses e isso complica ainda mais o trabalho do pesquisador.

Portanto, lançar mão da história como método na construção de uma pesquisa em comunicação nos parece ser plenamente aceitável, tanto do ponto de vista da eficiência metodológica, quanto do ponto de vista da validação de seus resultados, desde que o autor da pesquisa esteja consciente de que está lidando com atos humanos singulares, inseridos num dado contexto e marcados por uma temporalidade específica.

Do ponto de vista da construção de um referencial teórico, a presente pesquisa está claramente vinculada ao paradigma sociocêntrico, buscando apoio na 
Sociologia (notadamente na análise sociológica compreensiva e no conceito de Tipos Ideais de Max Weber); nos estudos sobre as alterações paradigmáticas do campo jornalístico; e nos conceitos que destacam a importância da economia na ação midiática.

A partir dessa base conceitual, acreditamos ser possível entender o processo de evolução do jornalismo no Brasil e suas relações com os campos político, econômico e social, bem como o surgimento dos primeiros impérios midiáticos brasileiros.

Em outros termos, a pesquisa, construída a partir de uma base teóricometodológica ampla e de características interdisciplinares, propicia uma aproximação com o objeto que nos permite perceber a ação humana presente nos fenômenos históricos que estariam ligados ao avanço do jornalismo no Brasil e o que isso provocou em nossas estruturas sociais.

Toda ciência, tomada isoladamente, não significa senão um fragmento do universal movimento rumo ao conhecimento. [...] Para melhor entender e apreciar seus procedimentos de investigação, mesmo aparentemente os mais específicos, seria indispensável saber associá-los, com uma característica perfeitamente segura ao conjunto das tendências que se manifestam, no mesmo momento, nas outras ordens de disciplina $(\mathrm{BLOCH}$, 2001:50).

Desse modo, as conclusões levantadas na presente pesquisa estarão amparadas e descritas a partir das seguintes disciplinas e áreas de interesse específico:

\section{SOCIOLOGIA E HISTÓRIA DO JORNALISMO}

Por tratar-se de uma pesquisa que busca desvendar estratégias políticas e escolhas econômicas que conduziram a importantes transformações na natureza do jornalismo praticado no Brasil, nos pareceu apropriado estabelecer pressupostos teóricos que tratem das questões que envolvem as mudanças nas práticas jornalísticas ao longo do tempo, buscando os fatores que nos permitam compreender tais variações, dentre elas o impacto da ação social dos proprietários dos veículos sobre a construção da notícia, por exemplo.

Segundo Weber (2001), é possível atribuir um tratamento científico aos fenômenos históricos construindo um modelo conceitual sociológico capaz de 
destacar "tipicidade" ou "homogeneidade" nesses fenômenos e, dessa maneira, conceder-lhes um status científico. Ele não acredita que essa condição possa ser alcançada por meio de uma conceituação lógica, numa visão aristotélica de ciência (TRAGTENBERG, 1973:XXIV).

Isso representaria, certamente, uma abordagem hermenêutica, muito embora Weber jamais tenha utilizado este termo, preferindo denominar sua prática metodológica de "sociologia compreensiva", pois "busca a interpretação do sentido da ação social sintetizada no método de interpretação, no qual estão unidas a compreensão e a explicação dos fenômenos (MORAES et all, 2003:58).

Ainda preocupado em garantir a necessária qualificação científica às ciências histórico-sociais, Weber defende uma abordagem metodológica baseada no estabelecimento de "tipos ideais", por meio da integração entre compreensão e experimentação, sintetizando "o objetivo e o subjetivo, o particular e o geral". Só assim, é possível entender a singularidade do fenômeno que nos interessa, exatamente aquilo que caracteriza os fenômenos histórico-sociais (TRAGTENBERG, 1973:XXV).

Com o propósito de compreender, a partir do ponto de vista históricosociológico, como o jornalismo no Brasil alterou seu caráter de predominantemente político-partidário para um jornalismo comercial, gerando as condições econômicas, políticas, técnicas e sociais que levaram ao surgimento dos primeiros impérios midiáticos no País é que nos apoiamos no conceito weberiano de tipos ideais.

Essa opção metodológica, aqui aplicada especificamente ao estudo da evolução histórica do jornalismo, já foi utilizada por alguns autores ${ }^{6}$ em pesquisas relacionadas à Teoria Organizacional para analisar, por exemplo, como se comportam as organizações ocidentais fortemente influenciadas pela ética capitalista.

\footnotetext{
${ }^{6}$ REED, M. Teorização organizacional: um campo historicamente contestado. In: CLEGG, S. R.; HARDY, C.; NORD, W. Handbook de estudos organizacionais. São Paulo: Atlas, 1998; e SROUR, R. Poder, cultura e ética nas organizações. Rio de Janeiro: Campus, 1998
} 
Ao considerar as organizações como sistemas burocráticos, a teoria weberiana permite o estudo dessas organizações a partir de seus aparatos ideológicos que justificam a sua racionalidade e destacando o que seria uma ação social significativa a partir do indivíduo. Na visão de Moraes et all (2003), este conceito pode ser estendido "às instituições como Estado, empresa ou sociedade anônima, que se transformam em palcos onde a ação é desenvolvida", como é o caso das empresas jornalísticas.

Há também o registro do uso dessa opção metodológica por parte de pesquisadores que buscam definir mudanças estruturais e paradigmáticas no jornalismo. É o caso dos estudos sobre a natureza e a transformação do jornalismo levados a efeito por Brin, Charron e Bonville (2007:9), que se apoiam no método do tipo ideal na tentativa de formular um quadro que defina o jornalismo em certa época, comparando-o a outro quadro de outra época.

Desse modo, torna-se plenamente possível descrever uma dada realidade a partir da substituição de tal descrição por um tipo ideal weberiano, uma representação abstrata da realidade que se busca compreender, lançando mão de alguns traços que o pesquisador considere típicos.

(...) representações depuradas, simplificadas e coerentes de fenômenos, de objetos ou de processos em que a complexidade excede amplamente as capacidades analíticas do pesquisador, mas que, reduzidas às suas dimensões essenciais, tornam-se inteligíveis (BRIN; CHARRON; et BONVILLE, Ibidem:9).

Concebendo a ação humana como elemento fundamental para a compreensão dos fenômenos sociológicos e para a formação histórica da realidade e utilizando-se dos "tipos ideais", Weber nos fornece um importante mecanismo teórico que "permite distinguir as formas organizacionais concretas e tornar inteligíveis fenômenos eminentemente complexos" (BRIN; CHARRON; et BONVILLE, Ibidem:10).

Ao identificar os tipos ideais, Weber (1979) dá a conhecer e a compreender os aparatos ideológicos que perpetuam e justificam a racionalidade no capitalismo ocidental, retirando o véu que ocultava as relações e comportamentos dos indivíduos no interior das organizações (teoria da burocracia, formas de dominação, formas do protestantismo etc) (MORAES; MAESTRO; DIAS, 2003:59). 
Munidos desse referencial teórico-metodológico, buscamos a compreensão necessária a respeito das singularidades históricas que marcaram as Mudanças Estruturais ocorridas no jornalismo brasileiro num determinado período, bem como a participação nesse processo de nossos personagens principais, Chateaubriand e Marinho, o que acabou por transformá-los em figuras centrais na história do jornalismo brasileiro, responsáveis por mudanças paradigmáticas na forma como o campo do jornalismo passa a se relacionar com o campo político, na construção da notícia e no estabelecimento de estruturas de financiamento de suas empresas.

Ao nos apropriarmos do conceito de tipo ideal, acreditamos ser possível compreender as ações, muitas vezes contraditórias, dos fundadores dos primeiros impérios midiáticos brasileiros nas suas diferentes manifestações e seus efeitos sobre os processos de construção e consolidação de suas empresas, confrontandoos com os episódios da história política e econômica do país em que estiveram envolvidos.

Nessa perspectiva sócio-historiográfica, a pesquisa permite, ainda, apontar como tais manifestações se refletiram nas condições de produção do jornalismo, no ambiente profissional, nos mecanismos de sustentação econômica e nas relações que o jornalismo mantém com a política, com os partidos e como elege os temas que considera de interesse social ao longo do período de formação e consolidação desse novo paradigma jornalístico iniciado no final do século XIX.

Para evitar que cometamos alguns erros de interpretação por conta da subjetividade inerente a esse tipo de avaliação, torna-se essencial que tomemos em consideração as limitações da observação histórica, uma vez que o conhecimento que se tem do passado é sempre indireto, através de vestígios, como lembra Marc Bloch (BLOCH, 2001:72), o que não o impede de que esteja em permanente aperfeiçoamento e, portanto, sujeito a reavaliações, mudanças de opinião e, muitas vezes, a reinterpretação de fatos já documentados.

Daí nossa opção por buscar compreender o fenômeno da transformação do jornalismo praticado no país ao final do século XIX e o surgimento dos primeiros impérios midiáticos no Brasil, por meio de sua reconstrução histórica e do impacto que provocou na sociedade brasileira. 
Toda a ação humana está sempre vinculada à história e à cultura, e estes são os maiores obstáculos existentes na produção de um saber que pretenda a abrangência explicativa na forma de um saber teórico. Devido às suas próprias características, a história e a cultura devem ser consideradas como objetos de conhecimento invencíveis (POKER, 2013:241).

Dentro dessa perspectiva, é justo reconhecer o árduo trabalho de construção de uma historiografia do jornalismo brasileiro a partir do esforço de estudiosos como Carlos Rizzini, Nelson Werneck Sodré, Antônio Costella ou José Marques de Mello; ou para citar pesquisadores contemporâneos, Isabel Lustosa, Marialva Barbosa ou Maria Alice Rezende de Carvalho, que tanto têm contribuído para o avanço da pesquisa comunicacional.

Buscamos, assim, o respaldo necessário para garantir o valor científico desta pesquisa, pois é certo que esses pesquisadores forjaram as condições essenciais para que o nosso conhecimento acerca do desenvolvimento do jornalismo brasileiro avançasse, vindo a constituir-se num campo de estudos cada vez mais utilizado para dialogar com as inquietantes questões acerca da importância da imprensa numa sociedade complexa como a nossa.

E é justamente a partir desse repertório e do diálogo com outras ciências que tratamos de buscar novas interpretações para a história do jornalismo brasileiro e para nossas questões de pesquisa, tendo em mente que "a historiografia moderna distingue-se da tradicional pelo diálogo com as ciências sociais, e pela aspiração à cientificidade" (NOVAIS E FORASTIERI, 2011:15), sendo, dessa forma, capaz de atribuir validade científica à questão que aqui levantamos.

\section{PARADIGMAS DO JORNALISMO}

O surgimento do jornalista profissional e a transformação dos jornais em empresas, no final do século XIX, no Brasil, representam a superação do jornalismo amador e a alteração do padrão editorial, saindo de cena a defesa de princípios e ganhando destaque o estilo fait-divers: as denúncias e reportagens tratando de "crimes, fatos extraordinários, curiosidades científicas, fenômenos paranormais e prodígios circenses" (CARVALHO, 2012: 48).

Mudanças Estruturais no jornalismo vêm sendo sistematicamente estudadas com o objetivo de permitir a melhor compreensão de como as práticas sociais 
afetam esse campo. Na Universidade de Brasília esses estudos visam, sobretudo, analisar os jornais e os jornalistas "observando como estes elementos se entrelaçam e se cruzam para caracterizar um momento de travessia turbulenta para o jornalismo brasileiro" (ADGHIRNI, 2012:61) e têm como campo de observação a realidade brasileira a partir da década de 1990, momento em que a Internet chega às redações.

Utilizado nas ciências sociais a partir dos estudos epistemológicos e da história da ciência levados a efeito por Thomas Kuhn, o termo paradigma representaria o conjunto de instrumentos, técnicas, métodos, problemas e teorias partilhadas por um grupo de cientistas num determinado período de tempo e que se prestariam à observação e à interpretação da natureza e de seus fenômenos, constituindo um corpus a ser estudado.

À medida que esse corpus cresce e incorpora novos problemas surge, naturalmente, o que Brin, Charron e Bonville (2007) chamam de "anomalias", ou seja, observações e resultados que já não são passíveis de serem entendidos a partir do conhecimento até então acumulado, provocando, dessa forma, a necessidade de se estabelecer uma nova teoria, uma nova explicação para aquele problema. A essa nova maneira de interpretar o fenômeno e de explicá-lo se atribui o termo paradigma.

Esse constructo teórico-metodológico, aplicado ao campo dos estudos jornalísticos, originou a expressão paradigmas jornalísticos, indicando que num espaço temporal definido, prevalecem determinadas práticas e concepções acerca do jornalismo. Mas é importante salientar que a descrição de tais mudanças se aproxima, na verdade, da noção de transformações de ordem estrutural. Essas Mudanças, portanto, não implicariam no abandono total de um determinado modelo e a emergência de outro padrão e de outros valores.

(...) haveria momentos na história do jornalismo em que se cristalizam práticas distintas - quando comparadas ao paradigma anterior. Revelam-se, portanto, como períodos de aparente descontinuidade no sistema normativo que define a prática jornalística. Tais transformações, entretanto, não seriam absolutas, na medida em que alguns valores, métodos e técnicas tendem a ser reafirmados e garantem certa estabilidade cognitiva e reconhecimento social a uma atividade (PEREIRA; ADGHIRNI, 2011:43). 
No caso do presente estudo, a utilização empírica desse conceito nos permitirá determinar as mudanças na prática e na cultura jornalística que se constituíram na base para a construção de um novo modelo de jornalismo no Brasil, fazendo com que a atividade evoluísse de um "jornalismo de opinião" (característico do início do século XIX) para um "jornalismo de informação", que surge no final do século XIX e vai estabelecer as condições materiais (econômicas, tecnológicas, profissionais e outras) que levaram ao aparecimento dos primeiros veículos comercialmente viáveis e, por fim, à constituição de impérios midiáticos no Brasil.

Acreditamos que ao analisarmos os diferentes paradigmas jornalísticos ${ }^{7}$ presentes na história do jornalismo brasileiro seja possível criar condições para que futuras pesquisas possam identificar outros elementos que também influenciaram nas mudanças editoriais e no formato dos veículos, como o processo de urbanização, o aumento da escolaridade da população e a influência de modelos estrangeiros de construção da notícia.

Existiria uma série de parâmetros constitutivos do paradigma [jornalístico]
que vão do texto jornalístico à estrutura econômica, passando pela ação
dos profissionais, das organizações midiáticas, das fontes de informação,
das práticas culturais e valores, elementos que interagem num contexto de
transformação (ADGHIRNI, 2012: 63).

Tendo, portanto, como referência as Mudanças Estruturais do jornalismo entre o final do século XIX e o início do século XX, destacamos as implicações sociais e políticas da implantação do jornalismo de informação no Brasil, evidenciando a multiplicidade e a complexidade das mediações promovidas pelos grupos de mídia e a sua credibilidade (difusão das informações junto ao leitor, ouvinte ou telespectador) e com isso "dar conta da realidade de maneira satisfatória (...) ter um alcance suficientemente geral para ser aplicada (...) nas diferentes fases de mutação que o jornalismo conheceu em sua história" (BRIN; CHARRON; et BONVILLE, 2007:1).

Buscou-se, assim, atingir o objetivo a que nos propusemos e compreender como evoluiu o jornalismo no Brasil e como essa evolução levou ao surgimento dos

${ }^{7}$ Le paradigme journalistique est défini comme «une manière spécifique et singulière de concevoir et de pratiquer le journalisme» (PRICOPIE et all, 2004:2) 
dois grandes impérios midiáticos brasileiros a partir de suas estruturas de financiamento e de apoio político.

Sendo assim, nosso modelo de análise buscou ser capaz de distinguir, com certo grau de segurança, as escolhas e as iniciativas das empresas jornalísticas do período estudado no campo editorial (artigos, manchetes, notícias, fotografias, estrutura das redações, rotinas de produção e tudo o mais que compõe a produção de informação jornalística), que pudessem ser apontadas como características de um determinado paradigma e que estejam diretamente relacionadas às estratégias formuladas por elas visando garantir e reforçar suas estruturas de financiamento, suas redes de relacionamento político e a sua legitimação social.

Essas dimensões essenciais do jornalismo estão presentes desde 0 começo da imprensa e são suficientes para definir o jornalismo enquanto prática de produção, de coleta e de dar forma, num jornal ou em outra mídia, aos discursos relativos aos objetos reais de interesse público (BRIN, CHARRON; et BONVILLE, Ibidem:5). ${ }^{8}$

É importante registrar que o conceito de paradigma jornalístico é eminentemente teórico e tem como função explicar e descrever a prática jornalística de determinado período. De maneira nenhuma se constitui numa preocupação presente na rotina dos jornalistas, como apontam Brin; Charron et Bonville.

$\mathrm{Na}$ definição que nós viemos dar, paradigma jornalístico é um conceito teórico. Ele toma seu lugar numa teoria para explicar a prática jornalística e sua evolução, mas ele está ausente, como tal, da prática jornalística concreta. $\mathrm{Na}$ experiência concreta da prática jornalística, com efeito, o conceito só pode ser apreendido, construído ou inferido, a partir de traços cognitivos no intelecto dos jornalistas individuais (BRIN; CHARRON et BONVILLE, Ibidem:5).

ECONOMIA DA MÍDIA

As ações individuais, as escolhas, os limites e os objetivos dos atores envolvidos nas mudanças observadas no campo do jornalismo são determinantes para a compreensão dos fenômenos econômicos ali representados. No caso da presente pesquisa, é fundamental identificar e avaliar o impacto das questões econômicas ligadas às Mudanças Estruturais do campo do jornalismo. Para lidar

\footnotetext{
${ }^{8}$ A tradução para o português do texto original em francês do qual foram extraídas as citações relativas a esses autores é de Márcia Marques e Rogério Dy La Fuente em 2008, material impresso e distribuído no âmbito do Programa de Pós-graduação da Faculdade de Comunicação da Universidade de Brasília.
} 
com questões dessa natureza os economistas desenvolveram modelos de análise baseados no comportamento.

Daí surgiu uma disciplina, a princípio denominada "economia da informação" e que nos últimos 20 anos ganhou fôlego a partir dos estudos desenvolvidos principalmente nos Estados Unidos e que Augey e Rebillard (2009) preferem chamar de "economia das mídias".

E quais são os problemas relacionados ao campo midiático que interessam a essa disciplina e que nos permitiram discutir conceitos e definir variáveis ligadas à história da mídia no Brasil? Basicamente, a economia das mídias compõe o referencial teórico para estudos relativos à concentração, condição que limita a diversidade, o pluralismo e o alcance do discurso midiático; ou ainda, sobre a existência de uma tendência ideológica nos mídias e qual a maneira de apontar essa tendência.

O estudo da economia das mídias permite, ainda, investigar que tipo de influência elas exercem sobre os processos decisórios utilizados pela sociedade. Por exemplo: podemos relacionar liberdade midiática ao crescimento econômico. Ou podemos investigar de que maneira a liberdade das mídias se constitui num fator inibidor da corrupção.

Se avançarmos na avaliação dos campos teóricos presentes no âmbito das ciências da informação e da comunicação perceberemos que a economia do jornalismo constitui-se num objeto situado na fronteira entre as abordagens socioeconômicas e as abordagens sociológicas, semiológicas ou históricas, que confrontam as mutações - concentração industrial, capitalização dos grupos de comunicação, diversificação - que influenciam o trabalho jornalístico. Justamente, questões fundamentais na busca de uma explicação para as mudanças observadas na estrutura econômica e editorial dos jornais brasileiros no século passado.

Ao mesmo tempo, o interesse da pesquisa não estaria plenamente atendido sem que o pesquisador procurasse entender a importância da dimensão econômica da mídia nos processos sociais em que se acha envolvida. Por isso, nos parece natural (e até mesmo imprescindível) que o trabalho lance mão de uma abordagem teórica que contemple os aspectos econômicos da ação social da mídia. 
Entender a relação entre a imprensa e o capitalismo como forma de organização econômica é essencial para pesquisas que tenham o jornalismo como objeto. Por isso vamos buscar apoio na visão de Weber sobre o capitalismo. (...) Ao estabelecer que a imprensa (em termos sociológicos) é necessariamente uma empresa capitalista Weber indica que não é possível compreender o papel e a ação da imprensa sem levar em conta sua natureza econômica, sua organização e suas estratégias para alcançar o lucro (MOREIRA, 2013:67).

Ao apoiar a presente pesquisa num referencial teórico-metodológico baseado na análise histórico-sociológica, usando o conceito de tipo ideal, levando ainda em consideração as alterações paradigmáticas do campo jornalístico e de sua economia é possível definir algumas categorias que permitam descrever e interpretar as mudanças porque passou o jornalismo brasileiro nas primeiras décadas do século $X X$ que resultaram no surgimento das empresas capitaneadas por Chateaubriand $e$ Marinho.

Só assim estarão delineados "marcos conceituais" que possam "acumular uma teoria de mudança aplicável ao jornalismo e traduzível dentro dos conceitos operatórios" (Brin; Charron; Bonville, 2007:1), constituindo-se num modelo explicativo para as mudanças que se observam nas estruturas de sustentação econômica dos veículos de comunicação brasileiros, no início do século $X X$, bem como para compreender como se dão as relações entre a política, a economia e a mídia nesse contexto.

Dessa forma esta tese encontrou o necessário respaldo teórico que nos ajudou a entender a complexidade do fenômeno que vimos estudando, ordenando o conhecimento obtido a partir de critérios de descrição e explicação dotados de consistência lógica, enfim, inspirando novas investigações a respeito do objeto, cumprindo dessa forma o importante papel de ampliar o interesse pelo assunto, mobilizando outros pesquisadores.

\section{DA METODOLOGIA}

O método científico é o caminho seguro para buscar uma aproximação com o objeto de estudo, seja por meio da identificação de regularidades no fenômeno observado, seja pela tentativa de isolar os elementos que caracterizam e distinguem tal fenômeno. 
Apesar do papel fundamental que o método desempenha no processo da construção do conhecimento científico, é possível afirmar que não há consenso sobre a metodologia a ser empregada no desenvolvimento e na dedução de uma teoria, "particularmente nas ciências sociais e humanidades" (SANTAELLA, 2001:131).

Na pesquisa científica, o método é a garantia de que o papel social da ciência prevalecerá sobre os interesses ou visões de mundo dos pesquisadores. Um método coerente e claro é condição fundamental para que se possa atribuir valor científico a qualquer estudo ou observação da realidade.

Compete à metodologia criar conceitos úteis e específicos que nos orientem e nos auxiliem em nossa investigação sobre os fenômenos pelos quais temos interesse. No caso de nossa pesquisa, estamos lidando com eventos influenciados pela convivência social e pelas configurações culturais e que devem ser considerados a partir de sua historicidade.

Por conta de seu caráter interdisciplinar, a comunicação, na condição de objeto de pesquisa e de formulação teórica, prescinde de metodologias específicas, estritas e que tenham prescrições técnicas claras. A metodologia a ser aplicada a uma pesquisa no campo comunicacional é, antes de tudo, uma escolha arbitrária do pesquisador, fruto de sua relação com o objeto e sua experiência na área.

Por lidarmos com a história do jornalismo é preciso cuidado com as limitações que este campo do conhecimento nos impõe. Não nos parece possível buscarmos a compreensão de fenômenos e de atores que estão distantes de nós no tempo sem que recorramos à teoria da história e aí surge um problema que afeta os estudos históricos do jornalismo.

Dentre as disciplinas das Ciências Sociais, constatamos que a História tem participação reduzida, discreta mesmo, na teorização dos fenômenos ligados à comunicação humana, limitando-se a listar correntes, teorias, estabelecendo uma cronologia relativa ao surgimento das teorias ou instituições (MOREIRA, 2011:26).

Segundo Barbosa (2013), mesmo tendo se formado a partir da interação com outros campos do conhecimento, os estudos comunicacionais trazem a marca indelével do "presentismo", o que faz do passado um locus inexplorado, pois a 
maioria dos pesquisadores em comunicação não percebem seus objetos "como inseridos num longo processo de construção" (BARBOSA, 2013:4).

E justamente por conta dessa característica recorrente nos estudos do campo da comunicação que nos preocupamos em não perder de vista o caráter processual dos fenômenos históricos e dos personagens que nos interessam, tendo o cuidado de não destacá-los do contexto em que se acham inseridos, olhando para o fato em todo o seu dinamismo, suas relações e implicações.

Assim, ao invés de nos determos exclusivamente nas materialidades (as
páginas dos jornais), nas gramáticas (o discurso que profere) e na
organicidade (as estruturas empresariais, gerenciais e processos
produtivos) há que visualizar, sobretudo, os sujeitos envolvidos diretamente
nessa história. A história do jornalismo deve ser também uma história das
ações humanas (Ibidem:7).

Mas é preciso tomar alguns cuidados. Uma armadilha metodológica comum quando lidamos com a história é olharmos para o passado com os olhos do presente, ou seja, analisarmos os fatos históricos tomando como referência nossos valores, nosso conhecimento, um conhecimento que não havia no passado, o que faz de nossa atitude metodológica o que Paul Ricoeur chamou de anacronismo.

A história é o passado ausente, o outro. (...) como nomear e dar a entender
com linguagem contemporânea algo que já ocorreu senão através de
similitudes funcionais: "tirania", "vassalagem", "feudalidade", "Estado", etc. O
historiador tenta vencer a distância temporal recorrendo à imaginação, que
lhe permite transportar-se para um outro presente que é o passado. A
imaginação histórica intervém, então, como meio heurístico essencial da
compreensão, abrindo uma fenda entre a história e as outras ciências
(SOARES, 2010:38).

E Ricoeur garante que cometemos um anacronismo ainda maior quando atribuímos aos homens do passado o conhecimento que temos da sequência posterior dos acontecimentos. Com isso, chegamos a conclusões e estabelecemos relações de causa e efeito que a eles (os homens do passado) seria improvável, ou até mesmo impossível, que ocorressem (RICOEUR apud BARBOSA, 2013:5).

Dessa maneira, tendo em vista nossos objetivos, foi preciso construir uma abordagem metodológica que garantisse, ao mesmo tempo, que fôssemos capazes de reduzir a realidade empírica a certas leis sem deixar de distinguir o essencial do secundário, relacionando os elementos da realidade a valores culturais universais, destacando as conexões que se mostram significativas. 
Na teoria de Weber constata-se a aposta na subjetividade do cientista para delimitar racionalmente um objeto e envolvê-lo por um método cuja lógica possa ser demonstrada objetivamente. Nesse caso, a objetividade seria, em última instância, tributária do grau de convicção do cientista em alcançar a necessária neutralidade axiológica no conhecimento que se dedica a produzir (POKER, 2013:242).

\section{DA OPERACIONALIZAÇÃO DA PESQUISA:}

Os estudos metodológicos oferecem uma variedade de opções quanto ao tipo de pesquisa a ser construído, o que depende, fundamentalmente, do objeto, do problema de pesquisa e da corrente de pensamento em que se insere o problema.

A escolha do pesquisador irá determinar procedimentos e atitudes envolvidas no processo de investigação, notadamente no que se refere às técnicas de manuseio de documentos, o que inclui a classificação, a organização dos dados e a construção de categorias que se prestem à análise do objeto.

Construir um arcabouço metodológico para estudar aspectos históricos do jornalismo significa, em primeiro lugar considerar as especificidades dos estudos de comunicação em sua longa trajetória. Em segundo, utilizar algumas premissas fundamentais da teoria da história, que podem fornecer pressupostos indispensáveis para se lidar com algo que chamamos passado. E, em terceiro, direcionar o nosso olhar para pensar o jornalismo como um lugar de evidência de uma pesquisa que trata de práticas e processos de homens inseridos em relações de comunicação (BARBOSA, 2013:2).

Diante dessas exigências e condições, lançamos mão das seguintes técnicas e práticas metodológicas, todas já testadas como possibilidades válidas de serem aplicadas na investigação científica:

\section{PESQUISA DOCUMENTAL}

Por conta da natureza do presente trabalho, do seu objeto e de seus objetivos, optamos pela pesquisa documental, procedimento metodológico que lança mão de métodos e técnicas visando à apreensão da realidade a partir da pesquisa dos mais variados tipos de documento.

[...] o conceito de documento ultrapassa a ideia de textos escritos e/ou impressos. O documento como fonte de pesquisa pode ser escrito e não escrito, tais como filmes, vídeos, slides, fotografias ou pôsteres. Esses 
documentos são utilizados como fontes de informações, indicações e esclarecimentos que trazem seu conteúdo para elucidar determinadas questões e servir de prova para outras, de acordo com o interesse do pesquisador (FIGUEIREDO apud Á-SILVA, 2009:5).

Nesse caso, foi necessário todo o cuidado para que não incorrêssemos no erro de "enxergar" numa ação apenas uma relação de causa e efeito e deixássemos de lado uma relação perfeitamente mensurável, onde se pudesse distinguir o sentido objetivo-funcional (WINCKELMANN, 1976:26).

\section{REVISÃO BIBLIOGRÁFICA}

Para a construção da variável de estudo relacionada à contextualização histórica e para a construção dos perfis biográficos das personagens foi conduzida uma revisão da bibliografia disponível (em português ou em qualquer outro idioma), além de utilizadas as informações obtidas nos periódicos, filmes, documentários e produtos audiovisuais relacionados aos personagens, suas empresas e aos eventos destacados na periodização.

Foram considerados, ainda, para a contextualização histórica e para a construção dos perfis biográficos dos personagens entrevistas concedidas por pessoas que conviveram ou participaram, de alguma forma, dos eventos estudados. 


\section{CAPÍTULO I - ACORRENTADA, DESBOCADA, APAIXONADA: ASSIM NASCE A IMPRENSA NO BRASIL}

A imprensa não surgiu antes no Brasil porque não fazia falta, não tinha a menor utilidade. O modelo de colonização e exploração imaginado e posto em prática pelos portugueses prescindia de qualquer tipo de transmissão periódica de informação. Éramos uma terra de analfabetos, de escravos e de aventureiros em busca da riqueza fácil. Como e por que implantar nessas terras, e sob tais condições, "a livre publicação regular e contínua de informações”? (MELO, 2003:48). Não fazia o menor sentido.

No prefácio que escreveu para a 1ạ edição do livro História Social da Imprensa. Fatores socioculturais que retardaram a implantação da imprensa no Brasil, de José Marques de Melo, Luiz Beltrão assinala que o atraso na chegada dos tipos e do prelo ao Brasil "não é uma implicância de Portugal com as suas colônias, pois não só não há disposições legais taxativamente proibitivas da implementação da imprensa como, em outras possessões lusas, a tipografia é logo introduzida" (Ibidem:16).

Werneck Sodré (1999) argumenta que Portugal não se preocupou em introduzir logo a imprensa na sua colônia americana por não ter encontrado aqui as mesmas condições com que se defrontaram os castelhanos em outras partes do continente, onde se bateram contra culturas avançadas e, portanto, tiveram de implantar os instrumentos de sua própria cultura para suplantá-las e substituí-las. "Essa necessidade não ocorreu no Brasil, que não conheceu, por isso, nem a Universidade nem a imprensa, no período colonial” (SODRÉ, 1999:11). ${ }^{9}$

\footnotetext{
${ }^{9}$ Nesta pesquisa, utilizamos a Edição de 1999, da Editora Mauad, porém, esta obra, considerada um clássico da História da Imprensa brasileira teve sua 1a Edição publicada em 1966, pela Editora Civilização Brasileira, do Rio de Janeiro.
} 
Parece-nos bastante razoável imaginar que num intervalo de tempo tão grande, que vai do início da colonização no século XVI até a chegada da família real portuguesa em 1808 (marco oficial da introdução da imprensa no Brasil), certamente houve tentativas de burlar a vigilância da metrópole produzindo-se, clandestinamente, algum tipo de impresso no Brasil.

Durante o domínio holandês em Pernambuco, por exemplo, que durou cerca de seis décadas, há registros de que a Companhia das Índias Ocidentais, por mais de uma vez, tentou obter junto a Amsterdã um prelo que permitisse agilizar as suas atividades burocráticas na região explorada, imprimido formulários diversos e letras de câmbio. Tal pedido jamais mereceu resposta da sede europeia, como registrado por Costella:

(...) O Conde de Nassau, administrador de decantado descortino, insistiu junto à direção da Companhia das Índias Ocidentais para que Ihe remetessem tipos e um artífice do prelo. O único tipógrafo que conseguiram contratar morreu antes de iniciar a empreitada. Depois, não encontraram mais ninguém, na Holanda, que se aventurasse a vir cá ao Brasil para exercer o mister. Com isso, não foi furtada aos lusos a primazia da impressão no Brasil (COSTELLA, 1970:18).

Ainda segundo este mesmo autor, a primeira tipografia a funcionar em terras brasileiras foi em Recife, em 1706. Mas não se sabe o que nela se imprimiu, se é que chegou mesmo a imprimir algo. O que se tem como certo é que uma Carta Régia (uma espécie de decreto Real), expedida em 8 de junho de 1706, mandava sequestrar as letras de câmbio e as orações que ali eram impressas, notificando seus proprietários que não "imprimissem livros ou papéis avulsos" (Ibidem:19).

Há, ainda, o registro de outra tipografia instalada no Rio de Janeiro, em 1746, por Antônio Isidoro da Fonseca, que também foi alcançada por uma ordem real que a mandou fechar, sequestrando os seus tipos e remetendo-os ao Reino. Portugal procurava justificar a proibição para a instalação de tipografias no Brasil por serem as despesas de impressão no Brasil maiores que na metrópole.

Mesmo por ocasião das tentativas de levante contra a coroa portuguesa, no período colonial, não se registra o uso de impressos ou publicações em apoio a esses movimentos. $O$ que se tem por certo é que durante a Inconfidência Mineira foram utilizados panfletos anônimos, que eram afixados em locais públicos, 
denunciando, sob a forma de sátira, os desmandos do capitão-general de Minas, Luís da Cunha Meneses, as famosas Cartas Chilenas.

Todavia, constituem as Cartas documento histórico de segunda plana. Carecem de alvo político e amplitude filosófica. A rigor, formam um requisitório moral e judicial, fundado na excelência do sistema governativo, magnitude da Coroa e santidade das leis. Não há, em nenhum dos seus quatro mil decassílabos, o mais leve desacordo com as instituições civis e religiosas, então francamente deterioradas. Seguisse-as, em vez de violálas, e Cunha Meneses teria sido governante benfazejo e benquisto (RIZZINI, 1968:121).

\subsection{DE COMO UM PRÍNCIPE INDECISO ACABA POR ENGANAR NAPOLEÃO.}

A vinda da corte portuguesa para o Brasil foi uma fuga apressada e mal planejada ou uma mudança estratégica, capaz de enganar o sagaz imperador francês Napoleão Bonaparte?

Enquanto esteve preso em Santa Helena, Napoleão ditou suas memórias, nas quais fez um balanço da vida e da carreira militar, com suas conquistas e derrotas. Para D. João VI reservou uma só frase, lacônica: "Foi o único que me enganou" (GOMES, 2007:326).

Nos primeiros anos do século XIX, a Coroa portuguesa vinha experimentando dificuldades políticas e financeiras, tendo perdido, já há algum tempo, grande parte do esplendor e poder que gozara no início do século XVI. A Revolução Francesa havia despertado temores num reino marcado pelo absolutismo, pela influência exacerbada da Igreja, pela ignorância da população, pela carência de indústrias, pela falta de um modelo econômico que fosse capaz de romper a dependência em relação às grandes potências europeias.

Inserido numa Europa dividida entre a força dos exércitos napoleônicos e a ganância dos financistas ingleses, Portugal tentava manter-se equidistante, preocupado em garantir sua integridade, assegurar seu império colonial ultramarino e as riquezas que de lá fluíam há quase trezentos anos.

A posição de Portugal neste período conturbado da história da Europa napoleônica era muito melindrosa. Apesar do país ser uma potência de importância marginal na guerra que alastrava pelo continente, não deixou contudo de assumir importância à medida que os acontecimentos relacionados com o conflito evoluíam (SCHEDEL, 2010:121).

A mudança da corte para o Brasil constitui-se num dos temas mais instigantes da História brasileira. Além de representar um fato inédito, envolvendo a transferência de uma corte europeia para uma colônia distante, dotada de um 
exuberante cenário natural, mas carente dos recursos mínimos para abrigar nobres, funcionários públicos, agregados, clérigos, serviçais e todo o universo de tipos e personagens que gravitavam em torno do rei, a chegada da família real portuguesa ao Rio de Janeiro abriu caminho para que o Brasil se tornasse, duas décadas depois, um país independente.

Apesar da ideia de mudar a corte para o Brasil já viesse sendo cogitada há certo tempo (FREITAS, 2006:78), do ponto de vista do planejamento e da organização, a partida (ou a fuga) foi quase um caos. A decisão da viagem foi tomada numa reunião do Conselho de Estado que se estendeu até a madrugada do dia 25 de novembro de 1807, ou seja, apenas quatro dias antes do embarque.

Além da dificuldade em escolher quem iria enfrentar a travessia do Atlântico, com seus perigos e incertezas, e quem ficaria à mercê da fúria do exército napoleônico, que rapidamente se aproximava de Lisboa, muitas medidas de caráter prático sofreram o impacto do estado emocional, dos interesses pessoais e, também, da incompetência dos que estavam encarregados da mudança.

\begin{abstract}
A situação era totalmente mesclada de desespero, desencontros e incidentes fatais com pessoas (entre elas senhoras distintas) que se lançavam ao mar na tentativa de alcançar alguma embarcação para se porem a salvo dos franceses, conforme registrou o tenente irlandês Thomas O'Neil, que estava em um dos navios da esquadra inglesa nas portas do mar (Ibidem:80).
\end{abstract}

Assim, a falta de critérios claros sobre o que levar para o Brasil provocou erros absurdos: equipamentos importantes e objetos valiosos foram abandonados, enquanto quinquilharias e coisas sem utilidade alguma ocupavam espaço nos porões dos navios que fariam a travessia.

A pressa foi tanta que, na confusão da partida, centenas de caixas repletas de prata das igrejas e milhares de volumes da preciosa Biblioteca Real, entre outras coisas, ficaram esquecidos no cais de Belém, em Lisboa. A prata seria derretida pelos invasores franceses e recuperada pelos ingleses alguns meses mais tarde. Os livros só chegariam ao Brasil em 1811 (GOMES, 2007:22).

Em tais condições, não se pode afirmar que o embarque de um prelo e de um conjunto de caixas de tipos na nau Medusa, um dos navios da frota, tenha ocorrido porque alguém se lembrou de que aquele equipamento era imprescindível para o funcionamento da nova corte, ou, se a exemplo de boa parte dos itens enviados ao Rio de Janeiro, foi simplesmente porque ninguém percebeu do que se tratava. 
De qualquer modo, a presença da família real no Rio de Janeiro criou as condições materiais para que no Brasil se passasse a imprimir regularmente livros, notas de câmbio, formulários e, também, periódicos. Mas no que diz respeito às condições políticas, essas ainda estavam longe de terem sido construídas.

Num cenário instável como o que vivia Portugal, fica claro porque o governo controlava com mão firme a imprensa tanto na metrópole quanto em suas colônias. Uma lei de 1768, durante o período pombalino, havia criado a Real Mesa Censória, que fazia do Estado a única autoridade sobre publicação e circulação de impressos (COSTELLA, 1970:12).

Os empecilhos à atuação da imprensa em Portugal eram maiores do que os existentes nos demais países da Europa Ocidental. O Estado português sempre buscou estabelecer uma série de restrições às publicações, sujeitas aos olhos atentos da censura exercida pelos membros do Tribunal do Santo Ofício. Essa situação decorria do grande poder exercido pela mentalidade religiosa que estava diretamente ligada à estrutura governamental (MACHADO, 2010:35).

Não havia, portanto, do ponto de vista político a possibilidade de desenvolvimento em Portugal da imprensa nos moldes já experimentados em outros países europeus, como a Inglaterra, a Holanda ou a Alemanha. Quanto ao Brasil, a situação era ainda pior. O receio da cobiça das demais potências europeias fazia com que Portugal mantivesse um controle extremamente rígido sobre qualquer tentativa de se imprimir periódicos, ou outros veículos de comunicação, que pudessem de alguma forma divulgar as suas riquezas.

As condições sociais encontradas pela corte portuguesa ao chegar ao Rio de Janeiro facilitavam muito o controle sobre a circulação de informações e notícias. A população, em grande parte analfabeta, pobre e carente, era mantida na ignorância pela metrópole, como forma de perpetuar a dependência e os vínculos comerciais entre Brasil e Portugal.

A ignorância e o isolamento eram resultados de uma política deliberada do governo português, que tinha como objetivo manter o Brasil, uma joia extrativista e sem vontade própria, longe dos olhos e da cobiça dos estrangeiros. Era uma política tão antiga quanto a própria colônia (GOMES, 2007:125).

Num primeiro momento, a imprensa surge no Brasil sob o império da censura, do controle da informação, da bajulação oficial e do silêncio imposto pelo governo português, principal motivo alegado por Hipólito José da Costa para imprimir o seu 
Correio Braziliense em Londres, longe do poder do Conde de Linhares, que revisava, avaliava e definia tudo o que se publicava na Gazeta do Rio de Janeiro, uma espécie de diário oficial da corte joanina no Rio e que circulou pela primeira vez em 10 de setembro de 1808.

É interessante notar que, apesar de sua aparência de "diário oficial”, a Gazeta do Rio de Janeiro era, na verdade, um empreendimento privado, uma concessão, um privilégio outorgado por D. João VI a um grupo de funcionários da Secretaria dos Negócios Estrangeiros e da Guerra, exatamente como o que existia em relação à Gazeta de Lisboa. Os recursos obtidos com a impressão do periódico (boa parte advindo, inicialmente, de assinaturas e de vendas avulsas; posteriormente, da publicação de pequenos anúncios e avisos) eram partilhados por esse grupo de oficiais, dentre os quais fazia parte frei Tibúrcio José da Rocha, primeiro redator da folha (DINIZ, 2014:3).

Esta Gazeta, ainda que pertença por privilégio aos Oficiais da Secretaria de Estado dos Negócios Estrangeiros e da Guerra, não é, contudo Oficial; e o Governo somente responde por aqueles papeis que nela mandar imprimir (BAHIA, 1990:13).

Mas o fato de ser controlada por funcionários da coroa portuguesa não significava que a vigilância sobre o que era publicado fosse de alguma maneira negligenciada por parte das autoridades lusas. Poucos dias após o decreto que estabeleceu sua criação, a Gazeta do Rio de Janeiro já era objeto de preocupações quanto ao que iria difundir na nova corte. Um Aviso, datado de 24 de junho de 1808 e assinado pelo próprio Rodrigo de Sousa Coutinho, responsável pela instalação do periódico, determinava a maneira como seria exercida a censura do conteúdo publicado pelo jornal.

A Direção terá o encargo de examinar os papeis e livros que se mandarem imprimir, e de vigiar que nada se imprima contra a religião, governo e bons costumes; e que sempre seja informada a Secretaria d'Estado, a cujo cargo está este estabelecimento (COSTELLA, 1970:20).

Durante todo o período em que a corte portuguesa permaneceu no Rio de Janeiro, a Gazeta do Rio de Janeiro teve como principal função reproduzir o que era publicado na Gazeta de Lisboa ou nos jornais ingleses, como se a dura realidade experimentada pelos cidadãos, brasileiros e portugueses, que aqui viviam simplesmente não se revestisse de interesse ou merecesse divulgação. 
Por meio dela [da Gazeta do Rio de Janeiro] só se informava ao público, com toda a fidelidade, do estado de saúde de todos os príncipes da Europa e, de quando em quando, as suas páginas eram ilustradas com alguns documentos de ofício, notícias dos dias natalícios, odes e panegíricos da família reinante. Não se manchavam essas páginas com as efervescências da democracia, nem com a exposição de agravos. A julgar-se do Brasil pelo seu único periódico, devia ser considerado um paraíso terrestre, onde nunca se tinha expressado um só queixume (SODRÉ, 1999:20).

Alguns estudiosos, porém, argumentam que mesmo considerando todos esses entraves e os objetivos atribuídos aos periódicos da época, a Gazeta do Rio de Janeiro terminava por oferecer mais do que simples informação oficial. Em suas páginas eram registradas as entradas e saídas dos navios que aportavam no Rio de Janeiro, as oportunidades de negócios e outras atividades mercantis.

Os primeiros números destacavam a invasão napoleônica e a resistência de portugueses e espanhóis: o "perigo francês" e a "guerra europeia" ocuparam inúmeras páginas da Gazeta. Inicialmente, tratava-se de um jornal semanal, publicado aos sábados, e depois terças, quintas e sábados, com vários números extraordinários (MACHADO, 2010:37).

A Gazeta do Rio de Janeiro circulou até dezembro de 1821, quando passou a denominar-se simplesmente Gazeta do Rio, até deixar de ser impressa em setembro de 1822, substituída pelo Diário Fluminense, órgão oficial do Império, que por sua vez daria lugar ao Diário do Governo, já no reinado de D. Pedro II.

\subsection{HIPÓLITO E O CORREIO BRAZILIENSE/ARMAZÉM LITERÁRIO}

As referências ao Correio Braziliense (ou Armazém Literário) na historiografia da imprensa brasileira convergem no sentido de atribuir-lhe a condição de primeiro periódico brasileiro, levando em conta o fato de que seu número inicial circulou, em Londres, no dia $1^{\circ}$ de junho de 1808 (portanto, três meses antes da Gazeta do Rio de Janeiro), o que garantiria a seu redator, Hipólito José da Costa, o título de primeiro jornalista brasileiro.

No entanto, há algumas vozes dissonantes entre os historiadores. Dentre elas a de Werneck Sodré. Segundo ele, a influência que o Correio Braziliense teria exercido sobre a opinião pública brasileira da época é, no mínimo discutível.

A influência do Correio Brasiliense, pois, foi muito relativa. Nada teve de extraordinário. Quando as circunstâncias exigiram, apareceu aqui a imprensa adequada. Por isso é que só por exagero se pode enquadrar o Correio Brasiliense no conjunto da imprensa brasileira (SODRÉ, 1999:28). 
Ainda segundo Sodré, Correio e Gazeta do Rio de Janeiro eram totalmente diversos quanto ao formato e as intenções. O Correio buscava "pesar na opinião pública", muito embora sua pregação estivesse muito mais ligada às questões de economia política (o fim do monopólio português em relação ao comércio brasileiro, por exemplo) do que à defesa da independência. E essa postura editorial se devia, certamente, à formação, à experiência e aos interesses defendidos por Hipólito.

Nascido em uma família influente, proprietária de terras na então Colônia do Sacramento (território tomado aos castelhanos pelos portugueses no que hoje é o Uruguai), em 25 de março de 1774, Hipólito percorreu, inicialmente, os mesmos caminhos dos jovens bem nascidos naquele período no Brasil. Foi educado por tios clérigos que o prepararam para o ingresso na Faculdade de Direito de Coimbra,em Portugal, onde se formou em meados de 1798.

Por conta do seu desempenho em Coimbra e da influência de sua família, tornou-se protegido de D. Rodrigo de Souza Coutinho, o Conde de Linhares, à época Ministro da Fazenda de Portugal e que defendia o imediato investimento científico-tecnológico em Portugal e no Brasil, visando aproveitar melhor o potencial econômico da colônia (LARANGEIRA, 2010:22). Isso fez com que Hipólito criasse um interesse especial pelas questões econômicas que envolviam as relações entre Portugal e o Brasil, principalmente a questão do monopólio comercial, assunto sempre presente nas páginas do Correio Braziliense.

Em 1798, na condição de funcionário do Ministério da Marinha e Domínios Ultramarinos, Hipólito foi enviado numa viagem de estudos à América do Norte (Estados Unidos e México). Na verdade, ele havia sido incumbido, secretamente, de obter informações valiosas sobre práticas agrícolas e industriais, bem como de produtos específicos encontrados naqueles países.

[viajou com] a determinação de fazer um diário com todas as observações e as recomendações para prestar atenção no território norte-americano principalmente no issin glass, ou cola fina, feita das vesículas de peixe de água doce e utilizada para depurar vinho e cervejas; na cola feita com bacalhau; na domesticação de búfalos e criação de cavalos; em todos os tipos de mineração; nas espécies de pinheiros e das novas gramas comestíveis desconhecidas na Europa; e nas culturas do tabaco, algodão, índigo, chás, cânhamo e vinhas (Ibidem:23). 
E segundo seus biógrafos, Hipólito estava devidamente preparado para essa missão, pois havia algum tempo que se dedicava, além da Filosofia e do Direito, ao estudo da Botânica, da Agricultura, da Zoologia, da Mineralogia, da Física e da Química (ALMEIDA, 2001:2).

No prefácio do seu livro Antologia do Correio Braziliense, o jornalista e historiador Barbosa Lima Sobrinho destaca a capacidade intelectual de Hipólito da Costa, o que se refletia nos artigos escritos para o jornal.

\begin{abstract}
O que mais nos surpreende no Correio Braziliense é a extrema variedade de temas que o compõem e a extensão de cultura que nele nos revela Hipólito da Costa. Conhece e discute tudo, desde a questão do tráfico e da escravidão até o problema da mudança da capital do Brasil. Mesmo em paralelo com os periódicos que surgem no Brasil, é o melhor informado de todos eles, o que melhor conhece e discute os problemas brasileiros (SOBRINHO, 1977).
\end{abstract}

Pesa contra Hipólito, porém, a acusação de que pouco fez ou que nem mesmo se interessava pela independência do Brasil e de que para manter o Correio circulando teria aceitado suborno.

\begin{abstract}
A tecla do suborno foi freneticamente batida por quantos na Inglaterra e Portugal, por conta do oficialismo, combateram o Braziliense. "O Correio tem por costume vender aqueles mesmos que o compram" (Padre Amaro, $\mathrm{V}, 234$. V. no $\mathrm{n}^{01}$ os elogios desse mesmo periódico a Hipólito). "Os armazéns de Hipólito se compram, como se compra o pão, e ali se aprende a governar o mundo de uma pocilga, onde a trolha é livro". (Pe. Agostinho, Os Burros, 212). "O editor do C.B. não tinha probidade alguma política, e indiferentemente vendia a sua opinião a quem melhor the pagava." (Liberato, Memórias, 194). "... estava vendido ao partido do conde da Barca" (Idem, 138) (RIZZINI, 1957:31).
\end{abstract}

O que podemos dizer com segurança em relação a Hipólito é o que inferimos a partir da leitura dos seus artigos: era um monarquista constitucional, que se inspirava no modelo britânico de governo e que temia as tendências democráticas propugnadas pela revolução francesa. As reformas que considerava essenciais ao Brasil deveriam ser feitas pela coroa e não pelo povo, o que para ele se constituía num risco sem precedentes.

Reconhecemos as más consequências desse modo de reformar. Desejamos as reformas, mas feitas pelo governo, e urgimos que o governo as deve fazer enquanto é tempo, para se evite serem feitas pelo povo (HIPÓLITO apud RIZZINI, 1946:352).

Bethania Sampaio Corrêa Mariani destaca, em artigo sobre os primórdios da imprensa no Brasil, que apesar da referência nominal à colônia, boa parte das 
notícias que o Correio Braziliense divulgava dizia respeito ao que ocorria na Europa e que Hipólito só fala do Brasil quando comenta documentos portugueses. A autora destaca que no seu primeiro ano de funcionamento o Correio publicou um total de dez artigos sobre o Brasil.

Uma primeira leitura a se fazer sobre o conjunto de textos diz respeito ao
espaço ocupado pelo Brasil no noticiário. Como se pode observar, as
poucas notícias, quando aparecem não encontram lugar fixo no jornal. Ora
na seção "Miscellanea", ora na "Literatura e Sciencias", ora na "Política", o
Brasil, enquanto acontecimento, vagueia pelas páginas do jornal e da
história. Tal falta de lugar corresponde a uma falta de definição do status
político do país perante as nações europeias (MARIANI, 2001:36).

Ao longo de sua história, o Correio Braziliense mostrou-se contrário ao absolutismo, contra a escravidão, pregou o livre comércio e o aperfeiçoamento do modelo de intervenção governamental no Brasil. Defendeu, ainda, a permanência de D. João VI no Brasil (publicou cerca de dezessete artigos a respeito do tema), mantendo-se longe das pressões que sofreria na Europa e garantindo a unidade do Brasil (LUSTOSA, 2000:77).

O último número do Correio (expressão do pensamento e da vontade de Hipólito da Costa) foi editado em janeiro de 1823. Em 11 de setembro daquele mesmo ano, Hipólito morre na Inglaterra, onde ainda esperava pela nomeação ao posto de Cônsul Geral do Império naquele país, ato que foi finalmente assinado pelo Imperador, no Rio de Janeiro, no dia 19 daquele mesmo mês de setembro de 1823 , ou seja, nove dias depois de morto o jornalista (RIZZINI, 1957:310).

\subsection{A IMPRENSA CORTESÃ}

No seu clássico História da Imprensa no Brasil (1999), Nelson Werneck Sodré estabelece a seguinte divisão temporal ou fases para a história da imprensa no Brasil $^{10}$ :

\footnotetext{
${ }^{10}$ Outros autores importantes estabelecem diferentes divisões temporais para a história da imprensa brasileira. Juarez Bahia (1990) considera as seguintes fases: Fase Inicial; Fase da Consolidação; Fase Moderna; e Jornalismo Contemporâneo. Já Carlos Rizzini (1946) prefere estabelecer uma cronologia de implantação da imprensa no Brasil, dividindo-a em três fases: 1808-1811, 1821, 1824-1852, tomando por referência a data em que as atividades de impressão tipográfica passaram a funcionar regularmente em cada região do país. Para Roberto Seabra (2002), são cinco as fases para o desenvolvimento do jornalismo brasileiro: jornalismo literário; jornalismo informativo estético; jornalismo informativo utilitário; jornalismo interpretativo; e jornalismo plural.
} 
1. A imprensa colonial

2. A imprensa da independência

3. O Pasquim

4. A imprensa do Império; e

5. A grande imprensa.

No período por ele denominado de Imprensa Colonial, Sodré destaca o controle da informação e as dificuldades que a imprensa vivia mesmo em Portugal. Os impressos tinham de passar por diferentes instâncias responsáveis pela censura, como a Inquisição e a Censura Régia. A mudança da corte para o Rio de Janeiro não altera em nada essa realidade. O diário que passa a ser publicado aqui permanece submetido às mesmas condições impostas pela censura.

As demais publicações que vão surgir ainda nesse período, como $A$ ldade de Ouro do Brasil, em Salvador e outros títulos de vida efêmera, vão formar o que Sodré chama de Imprensa Áulica. Segundo esse autor, esse período se constitui na proto-história do jornalismo brasileiro, relevante unicamente do ponto de vista cronológico e que tinha como motivação apoiar o absolutismo como forma de governo, que em declínio precisava "ver proclamadas as suas virtudes, de difundir os seus benefícios, de, principalmente, combater as ideias que the eram contrárias" (SODRÉ, 1999:29).

Esses periódicos do elogio e da louvação ao rei têm como principal motivação para suas existências opor-se ao Correio Braziliense, de Hipólito da Costa. Ainda segundo Sodré (1999:30), surgem como "folhetos de tipo panfletário e completandose, logo depois, como órgãos específicos de jornalismo". Alguns eram impressos nas oficinas da Impressão Régia e chegavam a ser enviados a Lisboa, onde passaram a circular depois da expulsão dos franceses. 
É o próprio Sodré quem resiste em reconhecer este tipo de periódico como imprensa. Para ele, o único critério possível para enquadrá-los nesta categoria é o cronológico. E conclui: "a fase serve, entretanto, para caracterizar a adversidade de condições políticas para o estabelecimento da imprensa. Porque, na verdade, as condições materiais começavam a surgir" (Ibidem:34), referindo-se à proliferação das oficinas artesanais de impressão que se verifica na colônia.

Entretanto, os números levantados por Marques de Mello indicam que durante o período em que a corte portuguesa esteve no Rio de Janeiro, somente duas cidades, Rio de Janeiro e Salvador, contavam com tipografias que funcionavam regularmente. Nas demais cidades, apenas depois de 1821, ou seja, após a Revolução do Porto, foram instaladas oficinas tipográficas. Mesmo assim, em algumas regiões mais remotas, levou mais de trinta anos para que os serviços de impressão estivessem disponíveis, como em Manaus, por exemplo, que só foi contar com esse tipo de atividade em 1852.

(...) a dinamização da imprensa em terras brasileiras só vai ocorrer depois da abolição da censura prévia no Reino. Se, até 1821, funcionaram regularmente tipografias em apenas 2 cidades (Rio e Salvador), a partir daquele ano mais quatro receberiam os seus benefícios (Recife, S. Luís, Belém, Vila Rica) (MELO, 1973:91).

Mas as tais condições políticas surgiriam sob a forma de um movimento revolucionário que se dá na cidade do Porto, em 1820. Uma das consequências mais importantes deste levante (que envolve não só os cidadãos, mas também parte da guarnição militar) é a discussão sobre a liberdade de expressão em Portugal e, por fim, o próprio processo de independência do Brasil.

Inicialmente, a revolta não pugnava por mudanças radicais. Nem mesmo pretendia estabelecer um regime republicano. $O$ objetivo era transformar Portugal de monarquia absolutista em monarquia constitucional, obrigando o rei a jurar uma constituição que ainda estava para ser escrita.

Os revolucionários liberais eram, de qualquer modo, moderados. Não cogitaram da instauração de um regime republicano. Queriam, apenas, criar uma monarquia constitucional, mantendo a casa reinante e preservando, se possível, a maior parte das instituições. 
Vedavam os revolucionários excessos ou abusos para não assustar, talvez,
o Soberano, que queriam de volta à Metrópole, e para não afastar certos
grupos moderados, cujo apoio era indispensável. Os liberais do Porto, em
suma, lutavam pela instauração de um regime, no qual a constituição
assegurasse que El'Rei ouviria seu bem-amado povo nas coisas da
governação pública (COSTELLA, 1970:27).

Com relação à imprensa, o governo provisório que se instalou em Portugal estabelece que "aos redatores dos periódicos e papeis que se imprimam nestes reinos, serão responsáveis à Justiça pelos ataques e insultos feitos a pessoas particulares", isso quando ficasse comprovado que os periódicos haviam inserido cartas, notas ou comunicações anônimas. Assim, o jornalismo português toma grande impulso, com o surgimento de várias publicações e o aumento exponencial do número de leitores. "Sente-se que em Portugal não mais havia censura" (Ibidem:29).

A questão da liberdade de imprensa tomou grande vulto e ocupou boa parte das discussões da assembleia constituinte portuguesa. $O$ projeto apresentado em 5 de fevereiro de 1821, e que tratava da liberdade de expressão em Portugal, tinha como inspiração a legislação espanhola sobre o assunto.

Assim, a liberdade de imprensa ganhava a condição de "salvaguarda da constituição", que no seu artigo $1^{\circ}$ estabelecia que "todo português tem direito de publicar os seus pensamentos sem necessidade de censura prévia".

Mesmo prevalecendo a ideia de que a liberdade de imprensa era uma questão fundamental para o fim do absolutismo em Portugal, a assembleia constituinte achava-se dividida quanto ao controle que o Estado deveria exercer sobre jornais, livros, panfletos e outras formas de expressão política.

Parte da assembleia pleiteava a completa liberdade de imprensa, sem nenhum mecanismo de controle ou de coerção. Outro grupo aceitava, de forma genérica, a liberdade de imprensa, admitindo, porém, a censura nos escritos que atacassem os dogmas e a moral católica (chamada de "censura dos bispos") e havia, ainda, outra parcela que pretendia a censura prévia a toda e qualquer forma de expressão escrita.

D. João VI protelou o quanto pode responder aos liberais do Porto, o que os levou a criar um governo provisório tendo como referência a constituição espanhola 
de Cádiz. Este documento faz alusão direta à liberdade de imprensa, garantindo que todos os cidadãos tinham a liberdade de escrever, imprimir e publicar suas ideias políticas, sem necessitar de licença ou autorização prévia (Ibidem:29).

No Brasil, o movimento do Porto repercutiu imediatamente. D. João questionou a legalidade das medidas tomadas pelo governo provisório, principalmente a convocação de uma assembleia constituinte. A questão maior girava em torno da volta do rei a Portugal, condição apresentada pelo governo provisório como fundamental para que o processo de transformação do país numa monarquia constitucional se desse sem maiores conflitos.

Ao hesitar, D. João deixava claro que seu desejo era o de permanecer no Brasil, mas sabia dos riscos que corria se tal decisão prevalecesse, com a muito provável perda dos privilégios da nobreza portuguesa. Foi nessas condições que começaram a circular no Rio de Janeiro e em Lisboa panfletos que reproduziam a correspondência de conselheiros e membros do gabinete português com argumentos contra e a favor da volta do rei a Portugal.

Segundo Isabel Lustosa (2000), foram esses panfletos que deram início, no Brasil, à prática de utilização de impressos para discutir os problemas do país, aproveitando-se do fim da censura prévia.

\footnotetext{
O que tornaria bastante comum após a liberação da imprensa e seria adotado tanto por personalidades como José da Silva Lisboa, quanto por gente de extração mais simples, como João Soares Lisboa e Stephano Grondona, entre outros. Era nesse tipo de prática que [o Visconde de] Cairu, um dos mais próximos colaboradores do rei, localizaria justamente 0 perigo da liberdade de imprensa (LUSTOSA, 2000:91).
}

\subsection{O PRÍNCIPE SE TORNA JORNALISTA}

O rumor das ideias liberais surgidas no Porto, em 1820, finalmente chegara ao Brasil. Algumas províncias, entre elas o Pará e a Bahia, aderiram à revolta, exigindo que se ampliassem os direitos dos cidadãos portugueses e brasileiros, o que deixou D. João VI numa situação bastante delicada.

Como era do seu feitio, o rei deixou-se levar pela ilusão de que tudo afinal se arranjaria. Quando resolveu agir, o fez de maneira inadequada, que teve como único mérito desagradar a todos: brasileiros e portugueses. Determinava, por meio de 
decreto, que D. Pedro retornasse sozinho a Portugal, porém sem poderes para jurar a constituição, ao mesmo tempo em que convocava uma assembleia no Brasil e nas ilhas portuguesas com o objetivo de protelar qualquer outra decisão (COSTELLA, 1970:37).

Vencido pela pressão do movimento revolucionário, D. João VI finalmente decide voltar a Portugal e jurar a constituição que se preparava. Partiu descontente, certo de que a independência do Brasil era uma questão de tempo. Não havia como evitá-la. No dia 26 de abril de 1821 o rei abandona o Brasil, convencido de que jamais voltaria a ser tão feliz quanto o fora naqueles tempos em que vivera na "mui leal e heroica cidade de São Sebastião do Rio de Janeiro."

Deixava para trás um país completamente mudado, que o acolhera com tanta alegria treze anos antes e no qual o processo de independência era já previsível e inevitável. Tão certa era essa possibilidade que (...) chamou o filho mais velho e herdeiro da coroa, então com 22 anos, para uma última recomendação: "Pedro, se o Brasil se separar, antes seja para ti, que me hás de respeitar, que para algum desses aventureiros" (GOMES, 2007:319).

Em pouco mais de uma década o Brasil havia mudado tão profundamente que jamais aceitaria voltar à condição de colônia de Portugal. E o responsável por grande parte dessa mudança foi, sem dúvida, o Rei D. João VI.

A maioria dos historiadores registra a importância que o período joanino teve para $\circ$ Brasil, principalmente para 0 processo de independência. Sem ele, provavelmente o país teria se fragmentado, a exemplo do que ocorreu na América espanhola, mantendo como único elemento de ligação a língua comum (Ibidem:326).

Investido ainda nos poderes de príncipe regente, em 28 de agosto de 1821, D. Pedro de Alcântara liberou totalmente a imprensa da censura, colocando em plena vigência os artigos específicos votados pela assembleia portuguesa.

Tomando S.A. Real em consideração quanto é injusto que, depois do que se acha regulado pelas Cortes Gerais Extraordinárias da Nação Portuguesa sobre a liberdade de imprensa, encontrem os autores ou editores inesperados estorvos à publicação de escritos que pretenderem imprimir, é o mesmo Senhor servido mandar se não embarace por pretexto algum a impressão que se quiser fazer de qualquer texto escrito, devendo somente 
servir de regra o que as mesmas Cortes têm determinado sobre este objeto. ${ }^{11}$

Apesar de todas as iniciativas no sentido de estabelecer a liberdade de imprensa no Brasil, D. Pedro não conseguiu livrar-se de suas tendências políticas, filho que era de uma família de absolutistas que temiam qualquer tipo de liberdade, principalmente a liberdade de expressão.

O historiador Hélio Vianna registra que, por conta das mudanças institucionais levadas a efeito em Portugal durante a Revolução do Porto, a imprensa política no Brasil surge, de fato, em 1821, apesar de haver jornais impressos e circulando no país desde 1808. Pela primeira vez em nossa história não há nenhuma restrição legal à expressão do pensamento (BAHIA, 1990:17).

A expansão do periodismo no mundo luso-brasileiro em 1821, o seu ano áureo, pode ser considerada semelhante àquela a que a França assistiu no período da Revolução de 1789 (...) Em Portugal, naquele ano [1821], surgiram cerca de 39 novos jornais, quase sempre publicados em Lisboa, Porto e Coimbra (NEVES, 2002:49).

A partida de D. João VI e a elevação do príncipe D. Pedro à condição de Príncipe Regente vão provocar uma inquietação política e um intenso debate público que se traduzirá no surgimento de periódicos brasileiros, que livres da censura prévia darão voz às diferentes correntes políticas que começam a se organizar no país. É o jornalismo participando da formação política do país.

A consciência de emancipação nacional mobiliza o Brasil de ponta a ponta. A imprensa é o elemento que faltava na composição de forças, de anseios e de aspirações voltados para a independência, para um ato de afirmação da autonomia. Nela o jornal político se projeta, seja em veículos efêmeros, alternativos, seja nos estáveis, regulares (BAHIA, 1990:35).

Geralmente esses periódicos eram redigidos por funcionários públicos ou por pessoas ligadas, de alguma maneira, ao governo e pregavam a continuidade dos laços entre Portugal e Brasil. Tiravam poucos exemplares e se atribuíam a missão de educar o povo para um novo momento político que surgia com a instauração de um regime constitucional.

Além da Gazeta do Rio de Janeiro e do Correio Braziliense, passam a circular na corte outros periódicos, como O Conciliador do Reino Unido, O Bem da Ordem, O

\footnotetext{
${ }^{11}$ Aviso publicado em 28/08/1821, por ordem do Príncipe Regente, D. Pedro de Alcântara
} 
Amigo do Rei e da Nação, que vão constituir o que Antônio Cândido denominou de "o ciclo literário de preito ao Rei", em que a figura de D. João VI e os demais membros da família real eram constantemente homenageados (CANDIDO apud LUSTOSA, 2000:102).

E com essas publicações surgem os primeiros jornalistas brasileiros, que além de redigir preocupavam-se com a impressão e a distribuição dos jornais. Nessa primeira geração de jornalistas brasileiros destaca-se a figura de José da Silva Lisboa, a quem José Bonifácio (o "Patriarca da Independência") só chamava de "fração de gente", por conta de sua compleição franzina e frágil, mas que passaria à história do Brasil como o "Visconde de Cairu", um dedicado servidor da Coroa portuguesa e do Império brasileiro.

Nascido em Salvador em 1756, Cairu era filho de um arquiteto português e de uma brasileira. Estudou em Coimbra, onde se formou em direito canônico e filosófico. Lecionou hebraico, grego e filosofia moral na Bahia, sendo indicado para o cargo de deputado da Mesa de Inspeção da Agricultura e Comércio da Bahia, o que Ihe fazia responsável pela aplicação da política econômica portuguesa na colônia (MONTEIRO, 2008:1).

Cairu teve papel fundamental no episódio de abertura dos portos quando da passagem de D. João VI por Salvador, na viagem que o levaria até o Rio de Janeiro, em 1808. Publicou livros importantes como Princípios de Direito Mercantil e Princípios de Economia Política. Foi o primeiro brasileiro a redigir e publicar um jornal de sua propriedade, O Conciliador do Reino Unido, cujo primeiro número saiu em $1^{\circ}$ de março de 1821 , no Rio de Janeiro. O que chama a atenção para este fato é que, à ocasião, Cairu era um dos responsáveis pela censura da Impressão Régia (LUSTOSA, 2000:101).

E no período que antecede à declaração de independência - e mesmo depois, já na condição de imperador do Brasil, o próprio príncipe se envolverá na publicação de vários desses periódicos, tornando-se um panfletário apaixonado, que procura defender suas posições esgrimindo a pena em artigos de linguagem forte, sem nenhum tipo de malabarismo retórico, sem nenhuma piedade de seus inimigos. 
Coube, assim, à Regência do Príncipe Real D. Pedro de Alcântara, iniciar, no Rio de Janeiro, as relações de nosso governo com os primeiros periódicos políticos aqui fundados e que tanta importância tiveram na preparação do movimento de opinião de que resultou a separação dos Reinos de Portugal e Brasil, com a nossa independência e a instauração do Império (VIANNA, 1967:33).

O futuro imperador tornou-se um polemista que não perdia oportunidade de criticar e ridicularizar seus desafetos, respondendo com veemência os ataques e opiniões contrárias publicadas nos jornais da corte. E o fazia utilizando-se de vários pseudônimos, como "P. Patriota", "Ultra-Brasileiro" e "O Inimigo dos Marotos"; ou simplesmente o fazia de forma anônima, como no panfleto Carta escrita pelo Sacristão da Freguesia de São João de Itaboraí ao Reverendo Vigário da mesma Freguesia, narrando os acontecimentos dos dias 9 e 12 de janeiro deste ano, no qual dava sua versão para o episódio do "Fico".

As incursões de D. Pedro pelo jornalismo político demonstram bem as dificuldades que Portugal enfrentava para manter unidos os dois reinos. Se os próprios portugueses se achavam divididos, como esperar que mantivessem o controle sobre o Brasil tão diverso e ávido por liberdade. Para Sérgio Buarque de Holanda, o processo de independência do Brasil pode ser atribuído muito mais a uma verdadeira guerra civil entre os portugueses do que à mobilização de brasileiros por sua liberdade (HOLANDA apud GOMES, 2007:331).

A declaração de independência em setembro de 1822 não extingue a agitação política. Ao contrário: apesar de se declarar um amante da liberdade (criticando, em algumas ocasiões, o racismo e a escravidão) ${ }^{12}$, o novo imperador não lidava bem com a crítica e com a oposição às suas ideias.

O jovem príncipe que se rebela contra Portugal e assegura a independência do Brasil é o mesmo imperador que logo depois dá um golpe dissolvendo a Assembleia Constituinte, permitindo que o absolutismo ainda encontrasse abrigo em nosso país. Antonio Costella transcreveu a justificativa do imperador para a dissolução da Assembleia:

\footnotetext{
${ }^{12}$ O historiador Hélio Vianna reproduz a narrativa do próprio D. Pedro sobre os festejos relativos ao Dia do Fico. “(...) eu aflijo-me de ver os meus semelhantes dando, a um homem, tributos próprios à Divindade. Eu sei que o meu sangue é da mesma cor que o dos negros." (VIANNA, 1967:18)
} 
Havendo eu convocado, como tinha direito de convocar, a Assembleia Geral Constituinte e Legislativa, por decreto de 3 de junho do ano próximo passado; afim de salvar o Brasil dos perigos que lhe estavam iminentes: e havendo esta Assembleia perjurado ao tão solene juramento que prestou à nação de defender a integridade do Império, sua independência e a minha dinastia. Hei por bem, como imperador e defensor perpétuo do Brasil, dissolver a mesma Assembléia (COSTELLA, 1970:53).

E coerente com esse comportamento próprio dos Bragança, ele traria de volta, mais tarde, a censura prévia, numa tentativa de conter seus opositores que utilizavam a imprensa para censurá-lo e questionar suas ações políticas.

\subsection{NA GUERRA PELA INDEPENDÊNCIA O JORNAL SE TRANSFORMA EM ARMA}

Como fato histórico, a independência do Brasil tem sido exaustivamente estudada e discutida a partir de seus aspectos políticos, econômicos, sociais e militares. Aos historiadores do Jornalismo brasileiro, no entanto, sempre interessou desvendar como se deu a mobilização popular para esse evento e que papel tiveram os jornais nessa mobilização.

A ainda incipiente imprensa brasileira foi responsável por fazer com que a questão da independência ganhasse importância fundamental entre a elite da época, polemizando, doutrinando e elegendo os temas que deveriam merecer a atenção dos brasileiros diante do iminente e inevitável rompimento com Portugal.

O fim da censura prévia decretada pelo governo provisório instaurado pelos constitucionalistas do Porto, em 1820, fez surgir uma quantidade razoável de publicações, principalmente no Rio de Janeiro. Jornais e panfletos passaram a circular livremente, apoiando ou combatendo as medidas que garantiam ao Brasil manter sua condição de Reino Unido a Portugal ou de tornar-se independente.

Nesses veículos, prevalecia o caráter ideológico, extremamente combativo, numa linguagem que muitas vezes beirava a agitação, virulenta e despudorada. Xingamentos, calúnias, ofensas pessoais e até mesmo o deboche por conta de defeitos físicos ou de caráter dos adversários eram comuns e faziam a alegria dos leitores.

A linguagem, tanto dos jornais de oposição quanto dos governistas, era em geral extremamente agressiva e virulenta, marcada que estava pela paixão dos debates e das polêmicas. A agressividade da imprensa - seja 
oposicionista ou governista, liberal ou conservadora - era reflexo do clima de exaltação e luta que marcou o processo da independência e o primeiro reinado (RIBEIRO, 2007:2).

Mas a garantia da liberdade de expressão era ainda muito precária, pois à medida que as discussões em torno da nova constituição avançavam ficava claro que esse era um tema em que não haveria solução consensual.

A relação tumultuada que se estabeleceu entre o príncipe regente e as cortes constituintes portuguesas acabou por ampliar a inquietação política no Brasil. Em resposta às insistentes tentativas de Lisboa em fazer com que D. Pedro acatasse as decisões ali tomadas, o príncipe convocou uma assembleia constituinte e legislativa para o Reino do Brasil. Esta iniciativa gerou enorme comoção e acirrou os ânimos entre os que defendiam as medidas do príncipe e aqueles que queriam manter os privilégios de Portugal.

E foi por meio da imprensa que esse confronto ganhou dimensões até então inimagináveis. O caráter artesanal e o modelo de produção dos jornais que se multiplicaram no Brasil exigiam pouco investimento. Além disso, tinham periodicidade bastante irregular. Não havia, portanto, grandes empecilhos a que se publicassem jornais com os mais diferentes propósitos e seguindo as mais diversas tendências políticas.

A irregularidade e efemeridade da imprensa desse período dizem respeito
ao seu próprio papel social. Como estavam ligados às lutas do seu tempo,
os jornais seguiam a dinâmica dessas lutas. Eram guiados, portanto, por
uma lógica conjuntural. Os periódicos apareciam e desapareciam conforme
os conflitos nos quais estavam envolvidos iam se configurando ou
reconfigurando (RIBEIRO, 2007:2).

Apesar de tais condições, a imprensa cumpriu um papel decisivo no processo de independência, abrindo um espaço para a discussão das relevantes questões que envolviam o futuro das relações entre Brasil e Portugal. Destacam-se nesse universo os periódicos O Conciliador do Reino Unido, de Cairu (que inicialmente pregava a manutenção do Reino Unido e dos laços entre Brasil e Portugal); 0 Espelho (criado em outubro de 1821) do qual era colaborador o próprio príncipe regente, cujos textos eram pontuados por palavrões, acusações e deboches; o Revérbero Constitucional Fluminense (de setembro de 1821); A Malagueta, cujo primeiro número circulou em dezembro de 1821 e que tinha como redator o 
português Luiz Augusto May, um feroz oposicionista ao príncipe regente e que acabou com a mão esquerda deformada num atentado de que foi vitima.

Depois de ganhar espaço na corte, no Rio de Janeiro, a imprensa alcança outras províncias importantes, dentre elas Bahia, Pernambuco, São Paulo, Maranhão, Pará e Rio Grande do Sul. Em Minas Gerais, O Compilador passa a ser publicado em 1823, seguido, algum tempo depois pelo Precursor das Eleições, ambos circulando em Ouro Preto, então capital da Província.

Em 7 de novembro de 1825 nasce aquele que viria se transformar no mais antigo jornal diário em circulação no país e na América Latina: O Diário de Pernambuco. Fundado pelo tipógrafo Antonino José de Miranda Falcão, começou a circular divulgando anúncios sobre venda e locação de imóveis, achados e perdidos e leilões. Com o tempo, o Diário de Pernambuco passa a publicar atos oficiais e ganha, assim, equilíbrio financeiro e certa independência editorial.

Em 1827, no Rio de Janeiro, surge outro jornal que tinha por objetivo manterse equidistante das diversas correntes políticas e, assim, assegurar sua independência editorial. Em pouco tempo o Jornal do Commercio torna-se o mais importante periódico do país e, pela primeira vez, temos um jornal próximo ao modelo do jornalismo comercial, independente, lucrativo, que já predominava nos Estados Unidos e nos países centrais da Europa.

O Jornal do Commercio do Rio de Janeiro é de $1^{\circ}$ de outubro de 1827 e mais um exemplo de imprensa independente que encontra espaço em meio às publicações predominantemente oficiosas, e provisórias, dessa fase. Sucede o Diário Mercantil e o Spectador Brasileiro, como resultado de uma manobra política e comercial do seu fundador, o impressor Pierre PlancherSeignot (BAHIA, 1990:39).

Muitos outros jornais vão surgir e desaparecer nesse período. A maioria absoluta mantendo as características de veículos políticos, ideológicos, instrumentos de divulgação de facções políticas. Quase todos acreditavam que tinham uma missão iluminista, educativa e que participavam da construção de uma nova sociedade.

Os jornais surgidos no Brasil entre 1821 e 1823, período de intenso debate político, de radical transformação das instituições, com mais razão ainda nasciam impulsionados por esse espírito [instruir e influenciar]. Seu propósito, segundo declaram quase sempre no editorial de estreia, seria o 
de preparar o povo para o regime liberal que se inaugurava (LUSTOSA, 2000:29).

E que impacto causaram esses jornais numa população que até então vivera dominada pelo absolutismo político legitimado pelo dogmatismo religioso. Foram esses periódicos efêmeros, precários, quase artesanais e seus redatores que familiarizaram o cidadão comum com as ideias e os conceitos iluministas, fundamentais para que participasse do debate político que se desenvolveria a seguir, com a assembleia responsável por redigir a primeira constituição brasileira.

E assim, nesse mesmo momento histórico, estabelece-se na cultura política brasileira o papel do intelectual, do homem de letras, aqueles que acabariam por constituir uma nova aristocracia que se sentia obrigada a participar e a interferir no processo político. Jornalistas que acreditavam estar destinados a cumprir uma missão.

(...) permeando todo o debate sobre o liberalismo, nesse novo momento em que a política se tornava pública, evidencia-se a preocupação de formar uma opinião pública, por parte da elite intelectual, especialmente dos autores dos folhetos e jornais. Nesses escritos, surgia como "dever do cidadão", isto é, daquele que escrevia, "dirigir a opinião pública, e levá-la, como pela mão, ao verdadeiro fim da felicidade social" (NEVES, 2002:56).

Citando Antônio Candido, Lustosa (2000) observa que "o intelectual considerado como artista cede lugar ao intelectual considerado como mentor da sociedade, voltado para a aplicação prática das ideias. A imprensa foi o meio privilegiado de sua ação" (LUSTOSA, 2000:33).

Durante o reinado de Pedro I imprensa e jornalistas viveram sob constante ameaça, vítimas de perseguições e de atentados, a exemplo do que feriu Luis Augusto May e matou Líbero Badaró, assassinado em São Paulo, em 1830. Esse cenário só se altera quando o imperador começa a perder o controle da situação.

\subsection{SEM O IMPERADOR O BRASIL AVANÇA E O JORNALISMO ENTRA EM} OUTRA FASE

O reinado de $D$. Pedro I foi marcado pela efervescência política. $E$ nem poderia ser diferente. O Brasil apenas começava a sua existência como nação soberana e suas instituições ainda não dispunham da força necessária para canalizar e dar vazão às notáveis divergências entre os grupos políticos que se 
organizavam. Além disso, o jovem imperador era voluntarioso e impaciente, pouco propenso a negociar e sempre pronto a responder, muitas vezes de forma desproporcional, aos ataques de seus opositores.

No cenário político, além de visões de mundo bastante diferentes, havia uma enorme diversidade de grupos de interesses que tentavam garantir espaço de representação política e a manutenção de privilégios econômicos. O embate era constante e os jornais, panfletos e outros impressos eram o campo de batalha mais comum, acessível e permanentemente disponível.

A produção da notícia obedecia a rotinas que envolviam um número reduzido de pessoas. O mais comum era que o jornal fosse redigido por apenas uma pessoa, que definia a pauta e produzia os artigos. E ainda, cabia a esse indivíduo buscar o financiamento que garantisse a impressão e a distribuição.

Eram, portanto, veículos artesanais, limitados em seu alcance e, por isso mesmo, de duração efêmera.

O próprio Hipólito se queixaria nas páginas do Correio do enorme trabalho que tinha para publicá-lo, das despesas e da necessidade de desenvolver, paralela à atividade jornalística, alguma outra que lhe garantisse o sustento da família (LUSTOSA, 2003:55).

Isso fazia com que a imprensa brasileira tivesse características que já não se viam nos jornais europeus do mesmo período. A precariedade técnica e financeira eram aspectos comuns a quase todos os impressos. E a ação e a atitude dos que produziam esses jornais eram muito parecidas, variando tão somente os interesses que se achavam envolvidos. A figura e a ação do jornalista eram, quase sempre, resultado de um engajamento político. Suas origens e formação obedeciam a um determinado padrão, que incluía funcionários públicos e religiosos.

Muitos padres acumulariam a condição de eclesiásticos e de funcionários
públicos e de jornalistas. A redação da Gazeta do Rio de Janeiro era uma
mistura de redação propriamente dita com repartição pública e claustro, não
só por conta do grande número de funcionários públicos e padres que nela
escreviam como por, apesar de se classificar como um empreendimento de
particulares, funcionar numa secretaria de governo (LUSTOSA, 2003:57).

Com raríssimas exceções, esse era o quadro representativo da imprensa e dos jornalistas logo após a independência e durante os anos tumultuados que marcariam o reinado de Pedro I. 
Em maio de 1822, quase quatro meses antes da declaração de independência, o então príncipe regente, D. Pedro, convocou uma Assembleia Constituinte, a primeira da nossa história, com o objetivo de elaborar e aprovar o documento que faria do Brasil uma monarquia constitucional.

Os eventos que se seguiram à declaração da independência fizeram com que os constituintes, representando 14 das 19 províncias, só tomassem posse em 1823. Era uma assembleia formada, unicamente, por representantes mais abastados da sociedade brasileira da época.

Na composição da Assembleia entraram as pessoas das classes sociais
mais elevadas da sociedade da época: bacharéis, padres, magistrados,
grandes proprietários de terras, funcionários públicos, militares, médicos,
etc. (...) Os nomes de maior prestígio eram os de Antônio Carlos Ribeiro de
Andrada, seus irmãos José Bonifácio e Martim Francisco, seguidos de José
da Silva Lisboa, Francisco Jê Acaiaba Montezuma, o marquês de
Barbacena, José Martiniano de Alencar, Muniz Tavares, Carneiro da Cunha,
Nicolau de Campos Vergueiro e outros (DEIRÓ, 2006:13).

Desde o início, as tendências absolutistas do imperador foram responsáveis por uma tensão constante entre os constituintes. Os jornais, principalmente os que estavam ligados à família Andrada, O Tamoio e $A$ Sentinela da Liberdade à BeiraMar na Praia Grande, denunciavam o envolvimento de Pedro I com grupos de portugueses, acusando-os de planejar a volta do Brasil à condição de colônia de Portugal.

Fiel ao seu temperamento, o imperador dissolveu a Assembleia em novembro de 1823, prendendo muitos de seus membros e impondo a censura aos jornais ligados ao grupo político dos Andradas. Convocado por D. Pedro, um grupo de notáveis elabora um projeto de constituição que é promulgada pelo imperador em 25 de março de 1824 e que traz, como elemento marcante, a instauração do Poder Moderador.

A constituição de 1824, a primeira do Brasil, refletiu o ambiente político instável que se observava no país logo depois de proclamada a independência. $\mathrm{Na}$ condição de figura central desse processo, e por conta de sua visão de mundo construída num ambiente político marcado pelo absolutismo, D. Pedro I não poderia deixar de interferir e de procurar fazer valer seus interesses na institucionalização do Estado brasileiro. 
A influência da cultura europeia junto à elite brasileira levaria, naturalmente, ao estabelecimento de uma carta constitucional que se amparasse na independência e no equilíbrio entre os poderes, o que completaria a transição do Estado absolutista para o Estado liberal. Mas não foi exatamente assim que as coisas ocorreram.

A insistência do imperador em garantir a prevalência do Poder Moderador sobre os demais poderes (Legislativo, Executivo e Judiciário), levaria a uma profunda crise política, que somada às dificuldades econômicas que assolaram o país logo após a independência gerariam a primeira grande crise institucional, culminando com a abdicação de D. Pedro I, em 7 de abril de 1831.

\begin{abstract}
Assim, nascida nesse período da história marcado pela transição do Estado absolutista para o Estado liberal e pela constitucionalização de direitos, e, principalmente, elaborada em período imediatamente subsequente à independência do Brasil, a Constituição do Império revelou um enorme progresso em termos de direitos fundamentais e demais garantias, mas também foi marcada por profundos antagonismos, (...) podendo-se afirmar que a nossa primeira Carta Magna era ao mesmo tempo antiga e moderna. De fato, a primeira Constituição brasileira era antiga porque constitucionalizou a chamado Poder Moderador, que se situava acima dos demais Poderes e conferia ao Imperador capacidade de agir quase que ilimitadamente, seguindo o modelo absolutista do qual a Europa tentava se libertar (VAINER, 2010:162/163).
\end{abstract}

O jornalismo, apesar de todos os problemas estruturais que experimentava naquele momento (atraso tecnológico, carência de recursos financeiros, subordinação aos interesses políticos), teve papel fundamental nesse processo de transição, contribuindo com a proposição dos temas mais importantes para a consolidação do país, dando origem a uma nova dimensão para a luta política: uma opinião pública que se pretendia capaz de interferir na construção do poder.

E são os próprios jornais, em sua ação didática, iluminista, que passam a se preocupar em definir o que seria esse conceito de opinião pública, seus efeitos e sua importância para os destinos do país. Morel e Barros (2003:30) reproduziram a definição de opinião pública apresentada pelo jornal oposicionista Nova Luz Brasileira, no seu nำ 21, de 19 de fevereiro de 1830 :

O que é - opinião pública - é o modo de pensar expresso e uniforme de mais da metade de um Povo sobre qualquer objeto: daqui vem a influência, poder e direção que dá a todos os negócios: sua vitória é sempre certa: desgraçado daquele que lhe faz oposição. 
O período imediatamente posterior à abdicação de Pedro I registraria um aumento exponencial no número de periódicos (jornais e revistas), além de panfletos, folhas volantes, cartazes e todo e qualquer veículo capaz de exprimir opinião, fenômeno relacionado ao aumento da luta pelo espaço político. É possível perceber nesse caso a importância que o jornalismo ganha num país de estruturas ainda arcaicas, no qual a maior parte da população se achava alijada das discussões e decisões políticas.

\subsection{QUEM ERAM OS LEITORES?}

Uma questão crucial quando buscamos compreender a ação da imprensa e sua capacidade de influenciar no debate público é conhecer, com a maior clareza possível, quem são os seus leitores. Na primeira metade do século XIX, no Brasil, o público leitor tinha características muito peculiares e que limitavam o alcance das publicações.

Os jornais, folhetos, avisos e panfletos impressos naquele período eram geralmente escritos por homens esclarecidos, membros de uma elite intelectual e política que buscavam atingir um determinado público na expectativa de que esse fosse capaz não só de ler, mas também de produzir sentido sobre aquilo que se discutia nessas publicações. E, com isso, estabelecer uma corrente de opinião apta a interferir na ação política.

É evidente que o potencial de leitura depende do número de habitantes. Os dados disponíveis sobre a população brasileira naquele período são extremamente precários. Ainda assim, a partir de uma Memória Estatística do Império, é possível afirmar, com certa segurança, que por ocasião da independência, a população brasileira livre girava em torno de 2 milhões e 800 mil pessoas, sendo que a população do Rio de Janeiro chegava perto de 43 mil habitantes (NEVES, 2002:54).

Mas qual seria o percentual de alfabetizados, aqueles a quem, evidentemente, essas publicações eram dirigidas? Além do país não contar com uma estrutura educacional que permitisse uma inclusão significativa da população no universo de leitores, somente aqueles que pertenciam às classes sociais mais abastadas tinham acesso ao ensino. 
$\mathrm{Na}$ ausência de dados estatísticos confiáveis, a pesquisadora Lúcia Maria Bastos P. Neves, do Departamento de História da Universidade Estadual do Rio de Janeiro (UERJ) utilizou, para estimar a população letrada do Rio de |Janeiro durante o Primeiro Reinado, alguns recursos que, segundo ela, podem ajudar a esclarecer a questão. Ela cita o procedimento utilizado pelo historiador Roderick Barman (1988), que analisou o Manifesto do Fico, assinado por um grande número de pessoas no Rio de Janeiro, em 1821.

Depois de considerar o número de habitantes e o número de assinaturas constantes do documento, Barman concluiu que cerca de $56 \%$ da população masculina, adulta, do Rio de Janeiro eram alfabetizados, o que não deveria, certamente, repetir-se em outras cidades, pois esses números equivaliam à porcentagem de alfabetizados em cidades francesas do século XVIII (Ibidem:55).

(...) o estranhamento e a perplexidade com os quase $80 \%$ de analfabetos são uma reação pública posterior ao final do século XIX. Em uma sociedade basicamente rural - mais de $80 \%$ da população -, comandada pelos grupos oligárquicos, com precários sistemas de comunicação, a demanda social de educação era também muito baixa (BONEMY, 2003:2).

Com relação ao restante do País, usamos como referência os dados obtidos durante o censo de 1872 (levantados decorridos cerca de cinquenta anos do período de agitação dos panfletos e periódicos publicados logo após a independência), que apontam, com absoluta clareza, que mais de $70 \%$ da população eram formados por pessoas incapazes de ler e escrever. 
TABELA 1- Número de pessoas livres que sabiam ler e escrever no Brasil em 1872

\begin{tabular}{|c|c|c|}
\hline PROVÍNCIA & SABEM LER E ESCREVER & ANALFABETOS \\
\hline ALAGOAS & 41.860 & 270.408 \\
\hline AMAZONAS & 7.613 & 49.018 \\
\hline $\mathrm{BAHIA}$ & 249.072 & 962.720 \\
\hline CEARÁ & 79.560 & 610.213 \\
\hline ESPÍRITO SANTO & 9.732 & 49.746 \\
\hline GOIÁS & 22.656 & 127.087 \\
\hline MARANHÃO & 68.571 & 215.530 \\
\hline MATO GROSSO & 10.922 & 42.828 \\
\hline MINAS GERAIS & 224.539 & 1.444 .737 \\
\hline MUNICÍPIO DA CORTE & 97.956 & 124.924 \\
\hline PARÁ & 60.395 & 187.384 \\
\hline PARAÍBA & 41.212 & 313.488 \\
\hline PARANÁ & 31.816 & 84.346 \\
\hline PERNAMBUCO & 147.325 & 605.186 \\
\hline PIAUÍ & 27.770 & 150.657 \\
\hline RIO DE JANEIRO & 114.600 & 375.487 \\
\hline RIO GRANDE DO NORTE & 39.822 & 181.137 \\
\hline RIO GRANDE DO SUL & 95.303 & 271.719 \\
\hline SANTA CATARINA & 21.926 & 122.892 \\
\hline SÃO PAULO & 141.067 & 539.675 \\
\hline SERGIPE & 29.134 & 124.486 \\
\hline TOTAL & $1.562 .851(22,8 \%)$ & $6.853 .668(77,2 \%)$ \\
\hline
\end{tabular}

Fonte: Censo de 1872. Dados ajustados a partir das pesquisas do Núcleo de História Econômica e Demográfica - UFMG -

Observação: a tabela não contempla o percentual da instrução escolar (06 a 15 anos). 
Mas quantos desses potenciais leitores estariam plenamente qualificados para participar do processo de esclarecimento político promovido pelos jornais? Essa é outra questão importante a ser respondida, se pretendemos definir o perfil dos leitores daquela época. Novamente nos deparamos com a dificuldade em obter dados a respeito dessa questão. E a resposta pode ser encontrada na própria imprensa, utilizando como referência os redatores e a maneira como avaliavam seus leitores.

Foi exatamente isso o que fizeram os pesquisadores Marco Morel e Mariana Monteiro de Barros (MOREL; BARROS, 2003), que conseguiram definir alguns aspectos quantitativos sobre o perfil socioprofissional dos leitores do início do século XIX. Os próprios pesquisadores admitem que são dados escassos e nãosistematizados, e culpam a precariedade dos arquivos brasileiros sobre o assunto.

Ainda segundo eles, um primeiro vislumbre sobre o perfil dos leitores pode ser obtido pela divulgação que alguns jornais faziam da quantidade de seus assinantes. Por meio desses dados, publicados nos próprios periódicos, foi possível definir um quadro que classifica os leitores dentro de categorias socioprofissionais.

Os comerciantes formavam o maior contingente, com 35\% dos leitores. Em seguida, vinham os militares, $22 \%$. Os clérigos ficavam em terceiro lugar, com $15 \%$. Com isso, essas três categorias formavam a maioria dos leitores dos jornais no Rio de Janeiro, no início do século XIX (MOREL; BARROS, 2003:36).

É interessante registrar que nos dados levantados pelos pesquisadores, aparecem, ainda, senadores, deputados, diplomatas, médicos e cirurgiões, empregados da alfândega e secretarias de estado, ou seja, segmentos profissionais que acabaram por construir um espaço público para o debate político no Brasil (Ibidem:36).

Outro fator importante para determinarmos o alcance do discurso jornalístico naquele período diz respeito ao preço dos jornais. Quanto custava a leitura de um diário? Quanto representava esse tipo de gasto para o cidadão da época? Neves (2002) faz uma comparação interessante entre os preços cobrados pelos jornais e os preços cobrados por outros produtos disponíveis no comércio do Rio de Janeiro, 
chegando à conclusão que esses periódicos não eram inacessíveis a grande parte do público.

\begin{abstract}
Numa época em que uma empada de recheio de ave custava 100 réis; um arrátel de linguiça, 280; um quartilho de tinta para escrever, 320; a aguardente de cana, 80 réis a garrafa; um sabão inglês, 120 réis a libra, os periódicos custavam, por número, em 1821, entre 80 e 120 réis. Os panfletos, segundo os catálogos do livreiro Paulo Martim, vendiam-se por um valor entre 80 e 320 réis. Chegava-se a afirmar na época que o povo, por faltar condições de ir ao teatro, divertia-se com os "bufões [os periodiqueiros] por pouco dinheiro" (NEVES, 2002:55/56).
\end{abstract}

Além do custo das publicações e do alto índice de analfabetismo entre os cidadãos das classes mais baixas, a forma como a sociedade brasileira estava organizada não contribuía para que houvesse uma maior participação política por uma significativa parcela da sociedade. Havia um contingente de excluídos, formado por escravos e despossuídos de toda a sorte. A esses, os jornais nem sequer mencionavam.

\footnotetext{
O redator do jornal $A$ Malagueta, em seu primeiro número, reconhecia que seu objetivo era o de provocar a análise crítica e justa de todos os cidadãos, isto é, "proprietários, gentes de guerra, diplomatas, legistas, comerciantes, lavradores, artistas, e de todos os que aqui compõem a grande família de homens livres" (Ibidem:57).
}

A renúncia de Pedro I ao trono do Brasil dá início a um novo período na história política do país, com o surgimento e a consolidação de instituições até então inexistentes (como os partidos políticos), a consequente ampliação do campo de luta político e de suas práticas.

Essas mudanças, aos poucos, irão se refletir também na imprensa, definindo novas configurações para o jornalismo no Brasil, sem, no entanto, provocar alterações essenciais no modelo que perdurou até o final do século XIX, mantendo-o "a serviço das lutas políticas” (ADGHIRNI, 2012:62).

Os pasquins praticamente desaparecem durante a "Conciliação", período que ocorre logo após a chegada ao poder de Pedro II, em que liberais e conservadores firmaram um pacto político com o objetivo de dar governabilidade ao País. O ministério formado pelo Marquês do Paraná, em 1853, o primeiro que reuniu "saquaremas" (conservadores) e "luzias" (liberais) foi uma tentativa de reduzir a tensão política e fazer avançar reformas econômicas necessárias às mudanças provocadas pelo avanço da cultura cafeeira e o fim do tráfico de escravos. 
Esse ambiente de aparente entendimento teve reflexos interessantes para a atividade jornalística, que viveu um período de liberdade plena que se prolongou por seis décadas. Conservadores e liberais alternavam-se no poder pacificamente, garantindo a manutenção das políticas e ações do governo que atendiam à elite rural e a manutenção dos inúmeros privilégios por ela conquistados.

[...] o segundo reinado, passados os seus primeiros anos, seria um longo e remansoso período de grande liberdade de imprensa. Basta dizer que durante quase 60 anos o direito substantivo não sofreu, no tangente à imprensa, qualquer alteração (COSTELLA,1970:66).

E os jornais, de uma maneira geral, aproveitaram essas condições favoráveis para ampliar as mudanças que fariam com que a imprensa viesse a se tornar uma atividade comercial lucrativa, melhor organizada, ainda presente nas lutas políticas, mas cada vez mais preocupada em manter-se distante da paixão partidária.

\subsection{O REGIME CAI, MAS TODO O RESTO PERMANECE}

Inicialmente, a Proclamação da República, em 1889, pouco mudou no jornalismo brasileiro. Aliás, as primeiras três décadas do novo regime em quase nada alteraram a vida do país. As instituições republicanas ainda traziam certo ranço do período monárquico. Muitos dos privilégios do velho regime continuavam em vigor e para o cidadão as coisas praticamente não mudaram.

A Proclamação da República não trouxe transformações econômicas,
sociais ou políticas radicais, nem marcou o ingresso do Brasil no concerto
das nações civilizadas. Ela não foi, como frequentemente se afirma, o
desfecho das questões religiosa e militar do fim do Império, dos excessos
cometidos pela Coroa ou da insatisfação dos fazendeiros com a abolição da
escravatura; não foi também fruto de uma antiga e irreprimível aspiração
republicana nacional, que se teria manifestado desde os movimentos
revolucionários ocorridos depois da Independência; muito menos,
expressão do desejo libertário de segmentos oprimidos das classes
populares ou dos anseios liberais de uma nascente classe média urbana,
que os militares representariam (PATTO, 1999:2).

Ainda éramos um país rural, com a economia baseada numa agricultura pouco diversificada e nas mãos de uma "aristocracia" que lutava desesperadamente para manter o que the restava de poder e de dignidade.

De qualquer maneira, a chegada de um novo século traz consigo ventos de mudança, tanto para a sociedade quanto para o jornalismo. O Rio de Janeiro, capital da República e cidade mais importante do país, busca se modernizar, derrubando, 
literalmente, os entraves urbanos que the impediam de crescer, de se tornar cosmopolita.

Os jornalistas acompanham, com muito interesse, essa metamorfose desregrada e apontam as incoerências e os absurdos cometidos em nome do progresso e da civilização.

De olho na rua e, ao mesmo tempo, nos salões, João do Rio se mostrava atento aos contrastes de uma reurbanização eufórica, que perseguia, a partir do modelo francês de civilização, o caminho para o progresso a qualquer custo e desconsiderava uma parcela marginalizada da população, compulsoriamente expulsa do centro, rumo aos subúrbios e aos morros, onde ia construir sua habitação, formando o gérmen das atuais favelas cariocas (LEVIN, 2010:13).

Essa aproximação do jornalismo com os problemas do cidadão, reduzindo o espaço dedicado às intrigas palacianas e aos conchavos políticos, levando o repórter a "mergulhar com uma incrível curiosidade investigativa nas misérias e nos prazeres palpitantes da vida comum" (Ibidem:14), revela que os ventos de mudança que sopraram na Europa e nos Estados Unidos, ainda no início do século XIX, finalmente chegavam (ainda que como uma suave brisa) às redações da Avenida Central e da Rua do Ouvidor.

\begin{abstract}
A literatura internacional dedicada à história da imprensa costuma sublinhar fatores demográficos e sociais para justificar tal mudança. A urbanização acelerada, o crescimento e a pauperização da população residente em cidades, a concentração de homens pobres e pouco escolarizados em transportes coletivos morosos, o interesse dessa população por notícias sensacionalistas seriam, enfim, fatores que justificariam a emergência de um tipo novo de jornal - mais barato, redigido de forma simples e recheado de informações sobre crimes e esportes (CARVALHO, 2012:39).
\end{abstract}

Apesar dos novos cenários político e social ainda estávamos longe das condições que fizeram com que o jornalismo se constituísse numa atividade lucrativa, a exemplo do que já ocorrera na Europa e na América do Norte, fazendo com que "a imprensa opinativa 'de partido', progressivamente, deixasse de ter expressão mercadológica" (SOUSA, 2008:144).

O objetivo dos novos veículos nos países centrais passa a ser, claramente, ganhar dinheiro. $\mathrm{E}$ isso implicava em aproximar-se do cidadão comum, afastar-se da luta político-partidária, usar uma linguagem mais acessível, saciar a curiosidade do homem simples, pouco letrado, sobre o avanço da ciência, explorar o interesse pelas aberrações, pelos crimes e por outros assuntos sensacionais, além de 
melhorar o processo de produção e aumentar as tiragens para ganhar com o aumento da venda avulsa.

Northclliffe [Lord] é uma das grandes figuras da história. Seu império é o primeiro da mídia populista. Tem o toque (ajuda Joseph Pulitzer a criar a famosa versão tabloide do World, que surge em 1 de janeiro de 1901, e alguns anos mais tarde lança o tabloide Iondrino Daily Mirror) e o modelo de negócios: jornalismo de massa. "Um jornal deve ser feito para se pagar. Deixe-o tratar do que interessa às massas. Deixe-o dar ao público o que ele deseja", pronuncia Northcliffe, para a grande e abrangente condenação de intelectuais (WOLFF, 2009:59).

No Brasil, a inexistência de uma classe média letrada, capaz de consumir regularmente as notícias produzidas; a falta de estabilidade das instituições políticas; e uma economia incipiente, na qual a geração de renda era insuficiente para manter um comércio de notícias regular e competitivo, são fatores apontados como causadores do atraso da transição do jornalismo brasileiro no final do século XIX.

Ainda na primeira metade do século XIX, o jornalismo norte-americano passou a servir de modelo para a imprensa em boa parte do mundo. E o Brasil não ficou imune a essa influência. A solidez das instituições políticas, a garantia da liberdade de expressão sustentada pela primeira emenda constitucional ${ }^{13}$ e as condições econômicas favoráveis, com o surgimento de uma classe média interessada em notícias e novidades, abririam caminho para uma imprensa comercial nos Estados Unidos.

Esse tipo de empresa está nitidamente preocupada com o lucro, equidistante das correntes ideológicas e pronta a incorporar toda e qualquer novidade tecnológica que the garanta tiragens maiores com melhor qualidade de impressão.

Nos Estados Unidos [...] logo na década de trinta do século XIX surgiram jornais predominantemente noticiosos, baratos, politicamente independentes, com um discurso acessível, direcionados para as pessoas comuns, encarados essencialmente como negócio empresarial, que começaram a competir com os jornais de elite dominantes. Esses jornais são a primeira geração de jornais populares. Eles recuperaram e reformataram as ideias originais das folhas volantes, dos livros noticiosos e das gazetas, que, entre os séculos XVI e XVII, geraram o jornalismo

${ }^{13}$ O texto da Primeira Emenda da Constituição dos Estados Unidos da América, ratificada em 1791, estabelece: Congress shall make no Law respecting an establishment of religion, or prohibiting the free exercise thereof; or abridging the freedom of speech, or of the press; or the right of the people peaceably to assemble, and to petition the Government for a redress of grievances. 
moderno, configurando-o como um negócio de produção e difusão de notícias (SOUZA, 2008:105).

Quase um século separa os momentos em que o jornalismo norte-americano e o jornalismo brasileiro buscam se firmar como atividade econômica. Enquanto nos Estados Unidos os jornais populares já haviam consolidado um novo modelo de informação lançando mão de notícias centradas no interesse humano, construídas numa linguagem mais clara e objetiva, no Brasil nossos veículos ainda estavam presos aos interesses político-partidários, mergulhados nos conchavos, nos ataques pessoais anônimos, onde o que prevalecia era o desejo dos que mantinham o jornal.

Coube a um francês, Max Leclerc, correspondente de um jornal parisiense que veio ao Brasil acompanhar os acontecimentos que se seguiram ao 11 de novembro de 1889, traçar um perfil da imprensa brasileira naqueles últimos anos do século XIX, conforme reproduz Werneck Sodré:

\begin{abstract}
A imprensa em conjunto não procura orientar a opinião por um caminho bom ou mau; ela não é um guia, nem compreende sua função educativa; ela abandona o povo à sua ignorância e à sua apatia. Os dois maiores jornais brasileiros, o Jornal do Comércio e a Gazeta de Notícias, realizam excelentes negócios: têm tantos anúncios que, não lhes bastando a terceira e quarta páginas, dedicam-lhes um suplemento (LECLERC apud SODRÉ, 1999:253).
\end{abstract}

Há, ainda, uma diferença significativa entre a imprensa brasileira e a norteamericana naquele período: a tiragem. Enquanto os cinco mais importantes jornais do Rio de Janeiro (capital do país), reunidos, imprimiam cerca de 150 mil exemplares, apenas o New York Journal chegou, no final do século XIX, a tirar cerca de um milhão de exemplares (CARVALHO, 2012:46).

Apesar de tais dificuldades, nosso jornalismo avança ao longo das últimas duas décadas do século XIX. Nos veículos que surgem nesse período já é possível perceber mudanças importantes, como a valorização de denúncias e de reportagens que buscavam aproximar-se da realidade do leitor.

Outra mudança significativa, ocorrida nesse período, diz respeito à profissionalização da atividade. O trabalho nos jornais deixa de ser um "bico", um segundo emprego e passa a exigir dedicação integral. Repórteres e redatores compõem um quadro fixo de funcionários e, assim, dedicam mais tempo às atividades que desempenham junto aos veículos. 
A divisão e a especialização de tarefas se ampliam e as redações e oficinas passam a abrigar um contingente de funcionários mais heterogêneo: repórteres, editores, revisores, tipógrafos, cada segmento dotado de uma cultura própria, marcada por rotinas diferentes, mas constituindo um universo extremamente rico e estimulante.

Há, ainda, uma alteração importante no que diz respeito aos investimentos feitos na modernização dos recursos gráficos. Era preciso aumentar as tiragens, imprimir, com maior rapidez, um número cada vez maior de exemplares, reduzir os custos, a fim de tornar o jornal um empreendimento economicamente viável.

As inovações técnicas na imprensa prosseguirão em 1895, já os jornais definindo-se com estrutura empresarial: aquelas inovações e esta estrutura estão intimamente ligadas. O primeiro prelo Derriey, italiano, para impressão de 5000 exemplares por hora, aparece nesse ano; nesse ano aparecem também os primeiros clichês obtidos por zincogravura, com os gravadores Antônio Freitas e Antônio José Gamarra, do Jornal do Brasil. A produção do jornal (porque, agora, já se pode falar assim) compreende várias operações (SODRÉ, 1999:266).

Com todas essas alterações foi possível atrair um número crescente de novos leitores que passam a buscar, avidamente, nas páginas desses jornais as notícias sobre crimes, esportes e tudo aquilo que compunha o universo popular das cidades brasileiras, que cresciam vertiginosamente, marcadas por problemas cada vez mais complexos.

Os primeiros trabalhos [de João do Rio] que despertaram a atenção dos leitores foram reportagens publicadas na Gazeta de Notícias [1904] dedicadas a fazer o mapeamento das práticas religiosas e crenças da população fluminense, com as quais o repórter desvendou os aspectos encobertos da espiritualidade popular. Em um primeiro conjunto de artigos tratou das seitas e rituais de origem africana. Fez visitas a terreiros e centros de candomblés, travou contato com mães de santo, orixás e líderes espirituais. [...] abordou seitas satânicas, fazendo a apresentação de práticas de exorcismo e de missa negra. Trouxe a público relatos sobre a igreja positivista e sobre as sinagogas israelitas, realizou reportagens a respeito das cartomantes, quiromantes, cultos evangélicos e rituais espíritas (LEVIN, 2010:13).

Essas mudanças importantes, envolvendo não só a construção da notícia, mas todo o universo em que o jornalismo opera, lançam as condições essenciais para o surgimento, no Brasil, de grandes grupos empresariais que têm origem em empreendimentos jornalísticos economicamente viáveis e bem administrados, ponto de partida para o que denominamos de impérios midiáticos brasileiros. 


\section{CAPÍTULO II - DA SUBVENÇÃO AO LUCRO: A IMPRENSA TROCA A POLÍTICA PELO MERCADO E O JORNALISMO NORTE-AMERICANO É O MODELO}

Se levarmos em consideração as estruturas de sustentação econômica do jornalismo brasileiro a partir da segunda metade do século XIX é possível afirmar que algo de essencial mudou em relação ao período anterior, que se inicia com a guerra da independência, atravessa todo o conturbado momento da regência, terminando com a conciliação e o golpe da maioridade de D. Pedro II.

O Imperador, ainda menino, foi entronizado como ato final de um grande arranjo político. Liberais e conservadores finalmente chegaram a um acordo e promoveram o "golpe da maioridade", com o objetivo de criar condições favoráveis ao desenvolvimento econômico.

E o jornalismo tem participação ativa nesse processo de construção de um modelo político que privilegia a economia, ajudando a restringir as possibilidades de influência dos demais atores políticos.

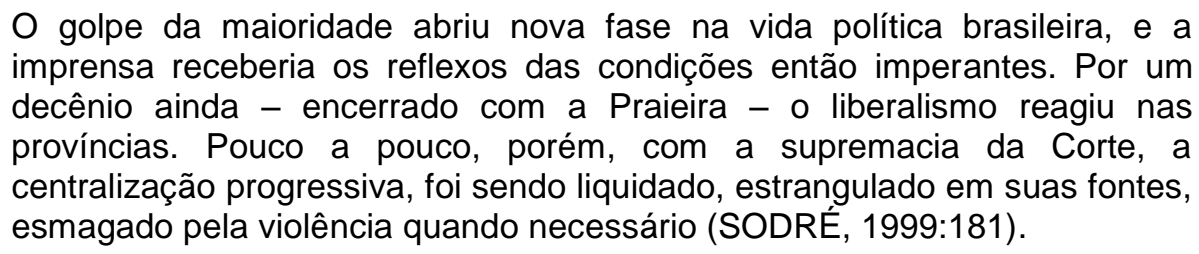

O que realmente mudou durante essa fase da história do nosso jornalismo? Mudaram a tecnologia empregada na impressão dos jornais e o formato; também mudaram os jornalistas e a maneira como construíam a notícia; mudaram, ainda, os leitores, as fontes de financiamento que mantinham os jornais funcionando e, principalmente, mudou o País.

Essas mudanças de alguma forma contribuíram, com maior ou menor importância, para esse momento de transição de um jornalismo "periodiqueiro", iluminista, doutrinário, centrado na luta política para um jornalismo em que os fatos começam a ser mais importantes; em que as alterações na economia e na política passam a ter um impacto mais perceptível na vida das pessoas; em que a estrutura 
social começa a se sofisticar e fica cada vez mais difícil "encaixar" os membros dessa sociedade em grupos homogêneos e determinados, defender ideias que pregam a manutenção de diferenças entre as classes sociais. Ou, então, manter fora da discussão política questões que surgem a todo o momento, como o novo papel da mulher ${ }^{14}$, as relações entre o poder político e o poder econômico, a escravidão, etc.

Do ponto de vista econômico, o fim do ciclo do ouro disponibilizou uma grande quantidade de mão-de-obra escrava, transferida imediatamente para a lavoura do café. A estabilidade política e o crescimento das exportações cafeeiras permitiram o aumento do controle político sobre a sociedade. E a corte, o Rio de Janeiro, passa a ter importância fundamental, centralizando as ações e definindo o destino do restante do país.

E os novos donos do poder ${ }^{15}$ tinham muito claro a importância do jornalismo e tomam as medidas necessárias para tê-lo sob controle, servindo aos seus interesses, garantindo a manutenção de uma sociedade escravocrata, sustentada pelo latifúndio do café (Ibidem:182).

A segunda metade do século XIX vai encontrar o Brasil com uma população de cerca de 7,5 milhões de habitantes, dos quais 1/3 ainda eram escravos (FURTADO, 2003:115). O Rio de Janeiro aparece no censo de 1872 como a maior cidade do país, com 266 mil habitantes, dos quais, 59 mil eram escravos. No total de habitantes da Província do Rio de Janeiro (782.000), o índice de analfabetismo chegava a $85 \%$. Das profissões listadas pelo censo não constam jornalistas, sendo que entre as profissões liberais, o maior contingente era de médicos, com 394 estabelecidos na cidade. ${ }^{16 .}$

$\mathrm{Na}$ década de 1870, as tiragens dos principais jornais do Rio de Janeiro aumentariam de forma significativa. Só o Diário de Notícias circulava com três mil

${ }^{14}$ Mesmo não tendo o direito de voto, o que as tornava, efetivamente, cidadãs de segunda-classe, os jornais começam a prestar a atenção e a discutir a importância da participação feminina na construção de um novo modelo político. (NEVES, 2002:58)

${ }^{15}$ A elite formada pelos maiores cafeicultores, principalmente os que possuíam grandes propriedades próximas ao Rio de Janeiro, chegando até o Vale do Paraíba, na região Nordeste da Província de São Paulo.

16 Fonte: DGE Recenseamento do Império de 1872, http://www.nphed.cedeplar.ufmg.br/pop72/index.html, acessado em 11/08/2014. Ver Tabela 1, pág. 53 
exemplares diários ${ }^{17}$. Este crescimento na circulação dos jornais e revistas foi impulsionado, principalmente, pela publicação de folhetins, fenômeno que já havia sido registrado na Europa e que os jornais brasileiros passaram a utilizar como recurso para ampliar o número de leitores e garantir sustentação econômica, distanciando-se da luta político-partidária.

É possível encontrar manifestações literárias nos jornais europeus desde 0 século XVII dividindo espaço com os textos políticos. A partir do século XIX a presença da literatura no jornalismo europeu se consolida e se espalha por quase todo o mundo. Inicialmente, o folhetim (feuilleton) referia-se ao espaço localizado no rodapé da primeira página, onde eram inseridas piadas, charges, receitas, curiosidades, informações úteis e, por fim, pequenas estórias e cartas de leitores.

Esse espaço foi sendo alterado até atingir um formato que o destacava do restante do jornal, no qual se passou a publicar obras ficcionais em capítulos. Os primeiros registros desse tipo de publicação vêm da França, em 1836, e tinham como objetivo a redução dos custos de impressão e o aumento das tiragens a fim de atender a um número crescente de leitores.

No Brasil, a publicação de folhetins nos jornais contendo traduções de obras literárias estrangeiras (sem qualquer tipo de autorização de seus autores) torna-se comum e desperta grande interesse nos leitores que, finalmente, passam a ter acesso a uma literatura de qualidade por preços razoáveis.

Entre 1830 e 1854, a partir do levantamento de J. M. Vaz Pinto Coelho, foram publicadas em periódicos brasileiros 74 traduções de obras de ficção, um número elevado em relação à produção nacional. (...) Foram traduzidos romances como $O$ conde de Monte Cristo, de Alexandre Dumas, e Os trabalhadores do mar, de Victor Hugo (com tradução de Machado de Assis para o Diário do Rio de Janeiro), concomitantemente à sua publicação em Paris (MOREL; BARROS, 2003:55).

Tornaram-se comuns os suplementos dominicais contendo obras literárias em capítulos, o que acabou por incentivar autores brasileiros a buscar esse meio para divulgar seus romances. O primeiro grande sucesso veio com O Guarani, de José de

17 Fonte: Biblioteca Nacional, http://bndigital.bn.br/artigos/diario-de-noticias/, acessado em $29 / 05 / 2015$ 
Alencar, publicado em 1857, no Diário do Rio de Janeiro e reproduzido em jornais de outras províncias (lbidem:56).

Outros nomes importantes da história literária brasileira usaram do mesmo artifício para tornarem-se conhecidos e alcançar um público maior: Joaquim Manuel de Macedo, Gonçalves Dias, Saldanha Marinho, Bernardo Guimarães e Machado de Assis foram alguns dos nomes presentes em jornais e revistas a partir da segunda metade do século XIX no Brasil.

Sodré (1999) registra que aquela foi uma época de grandes mudanças, não só para o jornalismo, que lado a lado com os temas políticos passa a promover o entretenimento, mas para a sociedade brasileira de uma maneira geral. Ele destaca a busca de novas atividades por parte dos capitais, o surgimento de bancos, das sociedades colonizadoras, das sociedades anônimas, das estradas de ferro. Tudo isso abre espaço para "a especulação, a agiotagem e o falso luxo" (SODRÉ, 1999:190).

Os jornais publicam avidamente essas novidades, que incluíam o surgimento da crítica teatral e a divulgação dos espetáculos em cartaz, as corridas de cavalo e as descobertas tecnológicas, além do noticiário internacional. A diversificação dos conteúdos jornalísticos coincidiu com a profissionalização da atividade e com a incorporação de novas técnicas de impressão, conforme registra Juarez Bahia:

Itens de escala técnica incorporam-se a uma tipografia que antes dependia
exclusivamente da habilidade manual. Inovações mecânicas, a divisão do
trabalho, a especialização, a racionalização dos custos, a conquista de
mercados pouco a pouco transformam a velha tipografia, aposentam
superados prelos, ampliam a indústria gráfica (BAHIA, 1990:106).

As mudanças econômicas, apesar de ainda serem insuficientes para acelerar o desenvolvimento do país e atender às demandas crescentes geradas pelo rápido crescimento da população, irão ampliar o trabalho assalariado e permitir uma maior diversificação da atividade empresarial.

Ao controlar mais da metade da oferta mundial de café, nas últimas três décadas do século XIX, a economia brasileira passa a reunir as condições necessárias à expansão do consumo, o que acaba incluindo o aumento no número de leitores de jornais e o consequente aumento de receita das empresas 
jornalísticas, representada pelas vendas avulsas, as assinaturas e a venda de espaço publicitário.

Essa nova realidade teve impacto importante no modelo de organização dos veículos, exigindo investimentos em máquinas e equipamentos, na manutenção de um contingente de trabalhadores cada vez mais especializados e nas estratégias de divulgação e distribuição de seus produtos.

As empresas jornalísticas passam, então, a oferecer serviços tipográficos, constituindo-se em organizações mais complexas, que necessitam de um fluxo cada vez maior de capitais. Na última década do século XIX, no Rio de Janeiro, então capital da recém-proclamada República, é possível encontrar jornais que já atuam como empreendimentos, tocados por profissionais especialmente dedicados às atividades inerentes à imprensa.

$\mathrm{Na}$ cidade do Rio de Janeiro [em 1891] jornalistas, cronistas, repórteres, revisores, chargistas, anunciantes, gráficos, vendedores e todos os demais elos da cadeia de produção e circulação de notícias compunham, por aquela época, o primeiro esboço de um campo jornalístico no Brasil (CARVALHO, 2013:39).

São inúmeras as inovações trazidas por esses veículos. Dentre eles, o Jornal do Brasil, "montado como empresa, com estrutura sólida. Vinha para durar". (SODRÉ, 1999:257). Ele introduziu a distribuição em carroças e espalhou correspondentes por vários países europeus e pelos Estados Unidos.

Fundado em 1887, por um dos personagens mais destacados do movimento abolicionista, José do Patrocínio, o vespertino Cidade do Rio inspira-se no americano New York Herald, e se apresenta como um novo modelo de empresa jornalística, onde a notícia se sobrepõe à informação.

Organizado em seções, impresso em quatro páginas, traz na capa notícias internacionais fornecidas pela Agência Havas. Não há grande destaque para os títulos e a linguagem é simples e direta, comparados com os jornais da época. Consegue, inicialmente, atrair um número considerável de anúncios publicitários.

O Cidade do Rio foi o primeiro jornal brasileiro "a pretender seguir o padrão americano de informação" (BAHIA, 1990:143), acompanhando uma tendência que já 
se espalhava pelo mundo e que tinha como inspiração os grandes jornais norteamericanos.

Mesmo contando com os melhores jornalistas da época e introduzindo uma série de novidades, o jornal não consegue sobrepujar as dificuldades estruturais que atingem a imprensa daquele período, principalmente a falta de um mercado consumidor, capaz de garantir retorno aos pesados investimentos necessários à sua modernização.

Ao contrário do que ocorreu na América do Norte, o fluxo migratório das últimas décadas do século XIX não criou as condições para o surgimento, no Brasil, de uma classe média capaz de sustentar um mercado consumidor de notícias.

O processo de urbanização no Brasil, principalmente no Rio de Janeiro, não se constituiu num elemento de estímulo ao crescimento da imprensa com a mesma intensidade observada nos Estados Unidos. A maioria dos moradores da então capital federal era formada por pessoas pobres, analfabetas, subempregadas, habitando moradias precárias nos cortiços espalhados pelo centro da cidade. Impossível pensar que essa parcela majoritária da população fosse capaz de garantir solidez econômica aos jornais da época.

Essa realidade se reflete nas tiragens dos diários. No final do século XIX, os cinco jornais mais importantes do Rio de Janeiro, Jornal do Brasil, Jornal do Commercio, Gazeta de Notícias, Correio da Manhã e O Paiz, juntos, tiravam cerca de 150 mil exemplares. Apenas o New York Journal vendia, diariamente, algo em torno dos 600 mil exemplares, chegando, a tirar mais de 1 milhão de exemplares durante a Guerra Hispano-Americana, em 1898 (CARVALHO, 2013:46).

A Rua do Ouvidor, no centro do Rio de Janeiro, sediava grande parte dos jornais que compunham a chamada "grande imprensa" da época, na maioria, matutinos que buscavam novas formas de construir a notícia, copiando modelos e fórmulas já consagradas na Europa e, principalmente, nos Estados Unidos.

O Jornal do Commercio é o mais antigo [...] com opiniões conservadoras. 0 Jornal do Brasil é o mais popular. Igualmente conservador, alinhado à política católica [...] O Paiz, tido como o mais fisiológico dos grandes [...] $A$ Gazeta de Notícias, favorita da elite cultural, tem uma tendência mais liberal. [...] A renovação da imprensa brasileira começou no Jornal do Brasil e na Gazeta de Notícias. A última, notadamente, divulgou as principais 
novidades surgidas em Paris e Londres: manchetes, subtítulos, reportagens, entrevistas, caricaturas (RODRIGUES, 2010:42).

Esse período corresponde, ainda, a uma considerável alteração das condições técnicas em que são produzidos os grandes jornais. Com isso, passa a ser comum a reprodução de fotos e ilustrações e o uso de novos recursos gráficos. Há, ainda, um aumento expressivo das tiragens (com o uso de novas impressoras, capazes de imprimir 20 mil exemplares por hora e movidas a energia elétrica) impulsionado pela busca de novos assuntos e pela aproximação com o universo dos leitores.

O jornal passa a ser usado como arma polêmica e também através das novas técnicas tenta se popularizar. E popularizar significava valorizar 0 grotesco, o violento, as matérias policiais. Essa valorização, muitas vezes levada ao extremo, faz com que os fatos policiais, as tragédias do quotidiano, as catástrofes sejam, de fato, o assunto principal. Popularizar também significa se transformar no intermediário entre o público leitor e 0 poder (BARBOSA, 2000:14).

Do ponto de vista da organização do trabalho, os jornais se esforçam por construir estruturas mais dinâmicas, que contam com a participação de diferentes profissionais, distribuídos segundo uma lógica produtiva baseada nos então recentes modelos tayloristas de gestão científica, que pregavam a divisão de tarefas e a especialização.

\footnotetext{
Novos processos de produção são introduzidos, com o trabalho da redação separado definitivamente das oficinas e com uma divisão de trabalho também nas redações. A criação da figura do repórter, um produto direto dessa divisão realizada por essas "fábricas de notícias", mostra claramente que agora não era mais possível a existência apenas dos redatores de banca, que escreviam sobre todos os assuntos (Ibidem:15).
}

Ao assumir esse novo modelo de construção da notícia e de organização, os principais jornais brasileiros do final do século XIX simplesmente têm no jornalismo norte-americano a referência maior para as alterações que naquele momento passam a implantar.

\subsection{O JORNALISMO NORTE-AMERICANO}

Os primeiros jornais apareceram nas colônias britânicas da América do Norte no início do século XVIII. Por volta de 1775, a imprensa já ocupava um papel central no debate público, vista como essencial para a liberdade, difundindo informações e opinião entre os "cidadãos livres" (KAPLAN, 2002:2). 
O The Boston News-Letter foi o primeiro jornal publicado regularmente na América do Norte. A sua tiragem era de trezentos exemplares e tinha muita dificuldade em conseguir assinantes e anunciantes. De acordo com a política da metrópole de controle de publicações, o jornal necessitava de uma licença para circular e seus editores respondiam, perante a justiça colonial, pelo conteúdo publicado.

Logo depois da guerra da independência, os jornais norte-americanos passaram a ser vistos como essenciais para a manutenção da democracia, assumindo a condição de instituição pública necessária para unir uma América do Norte culturalmente dividida e geograficamente dispersa (Ibidem:5).

Até o final da década de 1820, a imprensa dos Estados Unidos mantinha características muito similares às que se encontrava nos jornais brasileiros da mesma época, a chamada "imprensa da independência", como a define Isabel Lustosa (2000).

Geralmente semanários, os jornais americanos naquele período eram impressos com quatro páginas, sendo a primeira página reservada para a publicidade. As demais reuniam o editorial (invariavelmente sobre um tema político), avisos e anúncios sobre a movimentação de cargas e navios nos portos e, em alguns casos, pequenos artigos reproduzidos de outros jornais.

Normalmente, esses jornais (a exemplo do que ocorria no Brasil à mesma época) eram empreendimentos individuais, nos quais uma única pessoa respondia pelas atividades de edição, administração e impressão. Além disso, eram caros, se considerarmos o poder de compra dos cidadãos àquela altura.

\footnotetext{
Um jornal normalmente custava ao leitor seis centavos por edição, numa época em que o salário médio diário para não trabalhadores rurais era inferior a 85 centavos. Mas não se podia comprar um número de cada vez, exceto na sede das impressoras. Os jornais eram geralmente vendidos apenas por assinatura - e uma assinatura anual variava de 8 a 10 dólares. Não surpreendentemente, sua circulação era baixa, geralmente de um a dois mil exemplares, mesmo no caso dos mais importantes jornais metropolitanos. O leitor reduzia-se às elites comerciais e políticas; não era de se admirar, então, que o conteúdo dos jornais estivesse limitado ao comércio e à política (SCHUDSON, 2010:26).
}

Até 1830, o jornalismo norte-americano reproduzia exatamente o que se via nos jornais ingleses, imitando-os em praticamente tudo: formato, linguagem, pauta, 
etc. O que, então, teria levado os jornais dos Estados Unidos a mudarem tão radicalmente ainda bem antes da metade do século XIX?

Alguns estudiosos da história da imprensa norte-americana, dentre eles Linda e Robert Lichter e Stanley Rothman (1986), apontam como elementos fundamentais dessa mudança: o liberalismo norte-americano (de certo modo diferente do liberalismo inglês) fruto de estruturas sociais menos definidas, o que acarretava uma divisão de classes menos rígida daquela observada na Inglaterra; o rápido desenvolvimento de uma tecnologia gráfica, que propiciou o aumento das tiragens e o surgimento de uma imprensa de massa; e o comportamento dos jornalistas norteamericanos, que procuravam afastar-se de posições políticas ideologicamente arraigadas.

Esse conjunto de fatores fez com que os jornais se desenvolvessem "menos como porta-vozes de posições ideológicas conflitantes e mais como intérpretes desse conflito" (SILVA, 1991:59), o que abriu espaço para a valorização da notícia e para a verdadeira revolução que seguiu ao surgimento dos primeiros jornais da chamada "penny press".

[O] "jornalismo de centavos" corresponderia a uma tradução livre, para os dias de hoje, do que um dia foi a penny press, ou seja, uma modalidade de jornalismo que surgiu nos Estados Unidos na década de 1830 para atender a demanda, o gosto e o poder aquisitivo da classe trabalhadora (working class) e imigrantes, por iniciativa de empresários que viam nessa prática um achado mercadológico e auto-sustentável, isto é, de forma a não depender, financeira e editorialmente - como o fazia a "grande imprensa" da época -, de partidos políticos (party press) (DA SILVA; PAULINO, 2014:1).

\subsection{ENTRAM EM CENA O REPÓRTER E A NOTÍCIA}

No final da década de 1820, havia uma percepção, entre os jornalistas norteamericanos, que o editorial estava morrendo e só a notícia era o "ponto de rivalidade" entre os jornais. O sucesso de um jornal dependia "total e absolutamente de seu êxito em obter - e de sua habilidade em exibir - a notícia" (PARTON apud SCHUDSON, 2010:37).

E competia ao repórter ir buscar, nas ruas, a notícia, moldando-a ao gosto, aos interesses e às habilidades linguísticas de seus leitores, grande parte deles imigrantes com pouco domínio da língua inglesa. 
Os repórteres eram distribuídos entre a polícia, os tribunais, o distrito comercial, as igrejas, a alta sociedade e os esportes. Os penny papers fizeram da "narrativa de interesse humano" não somente uma parte importante do jornalismo diário, mas seu aspecto característico (SCHUDSON, 2010:39).

Ao oferecer a notícia como um "produto", os jornais passam a permitir aos leitores a comparação entre eles e a partir de critérios encontrados na própria notícia, acontecimentos singulares em que se destacava o aspecto humano, a vida cotidiana, fatos com os quais os leitores se identificavam protagonizados por personagens nos quais se reconheciam.

No início da década de 1830, circulavam nos Estados Unidos 650 jornais semanais e 65 diários. Esses últimos tiravam, em média, 1.200 exemplares, o que elevava a circulação diária próxima a 78 mil exemplares. Dez anos depois, os jornais semanais haviam saltado para 1.141 e os diários para 138, com uma circulação média de 2.200 exemplares e uma tiragem diária total de cerca de 300 mil exemplares. ${ }^{18}$

Schudson (2010) acrescenta um elemento sociológico às explicações para esse aumento vertiginoso no número de jornais nos Estados Unidos naquela época. Segundo ele, além da evolução da tecnologia gráfica e de impressão e do aumento do número de cidadãos alfabetizados, as substanciais alterações ocorridas na imprensa norte-americana, ainda no início do século XIX, dizem respeito a um percurso histórico natural de evolução do próprio jornalismo, apoiando-se num conceito desenvolvido por Walter Lippmann:

\footnotetext{
Num primeiro estágio, a imprensa é um monopólio controlado pelo governo. Ela passa, então, para um estágio em que os partidos políticos, e não o governo, controlam a publicação. No terceiro estágio, rompe com ambos, governo e partidos, "ao atrair o suporte comercialmente rentável de uma grande massa de leitores". Nos Estados Unidos, naturalmente este estágio tem início com os penny papers (Ibidem:53).
}

O primeiro jornal do tipo penny paper, o New York Sun, começou a circular em setembro de 1833 e em apenas dois anos já vendia mais de 15 mil exemplares

${ }^{18}$ Os dados relativos à circulação dos jornais americanos entre 1830 e 1840 foram retirados de SCHUDSON, 2010:24, que por sua vez utilizou como referência LEE, A.M. The Daily Newspaper in America. Nova York: Macmillan, 1937, p. 705-753. 
diários. Dois anos depois, em maio de 1835, a circulação conjunta de apenas três desses jornais chegava a 44 mil exemplares.

Invariavelmente, o conteúdo publicado pelos penny papers destacava notícias locais, deixando pouquíssimo espaço para as notícias políticas. Muitas de suas páginas eram preenchidas com relatos de intenso apelo humano, violência sexual, crimes e curiosidades científicas.

\begin{abstract}
Os jornais de massa, baratos, surgiram concomitantemente a uma nova "sociedade de mercado democrática", a qual se definia como uma nova e igualitária sociedade urbana, apartada das disputas políticas a respeito do bem comum, estimulada por uma economia de mercado que se expandia enormemente e que estava interessadíssima em histórias relacionadas à quebra das normas sociais e de elevado "apelo humano" (KAPLAN, 2012:5) ${ }^{19}$.
\end{abstract}

Ao aumentar a circulação, esses novos veículos garantiram, também, um aumento significativo no espaço publicitário, o que lhes permitiu investir em novas tecnologias de impressão, além de obrigá-los a racionalizar seus métodos de gestão. A publicidade passa, então, a fazer referência direta ao cidadão comum e os maiores anunciantes são os fabricantes de medicamentos.

Uma nova fonte de receita surge por meio dos anúncios classificados (os Want Ads), reflexo de uma urbanização acelerada que criava novas necessidades materiais e novas formas de relacionamento, num espaço social marcado pela perspectiva da igualdade democrática e da possibilidade de ascensão social.

Os Estados Unidos, até então um país agrícola, passam por mudanças substanciais que rapidamente atingem sua população. O desenvolvimento dos transportes e a perspectiva de prosperidade econômica marcaram o cidadão americano naquelas primeiras décadas do século XIX.

O florescimento da manufatura no leste e o rápido povoamento do oeste preencheram largamente o espírito de empresa. $\mathrm{O}$ americano típico era um promissor capitalista, um duro trabalhador, uma pessoa ambiciosa para quem a empresa era uma espécie de religião e por toda parte ele encontrava estímulos para ampliar o seu negócio (HOFSTADTER, 1948:55).

${ }^{19}$ Tradução do original em inglês feita pelo autor 
Esse período da história americana é conhecido como a "Era Jacksoniana", em referência ao Presidente Andrew Jackson (7ํㅜㄹ Presidente dos Estados Unidos) cuja doutrina estava assentada sobre os ideais de democracia participativa, de igualdade de oportunidades, no combate a todo o tipo de monopólio e às formas de privilégios.

Esse novo ambiente político e social foi, em grande parte, responsável pela mudança observada no jornalismo norte-americano, que se propugnava independente dos segmentos políticos e que tinha como objetivo "colocar diante do público, a um preço ao alcance de qualquer um todas as notícias do dia e, ao mesmo tempo, oferecer um vantajoso meio de publicidade", conforme nota publicada no New York Sun em dezembro de 1833.

Encontramos na literatura especializada relativa à história do jornalismo norteamericano algumas explicações para a chamada revolução do penny press. Autores como McClung Lee (The Daily Newspaper in America, New York. MacMillan, 1937), Schudson (2010) e Kaplan (2012) enxergam nos fatores tecnológicos (avanços nos processos de impressão, o desenvolvimento do transporte ferroviário, seguido pelo surgimento das comunicações telegráficas) e na ampliação da alfabetização elementos fundamentais para o desenvolvimento de um jornalismo industrial nos Estados Unidos, ainda na primeira metade do século XIX.

Há, ainda, outro fator muito importante no processo de transformação da imprensa americana nos anos de 1800, num movimento que a afastou do discurso partidário e a consolidou como fonte de informação factual: o surgimento das agências de notícias.

Kaplan (2012) atribui ao noticiário imparcial e padronizado produzido pelas agências um papel fundamental na construção de uma imprensa comercial, de massa. Um crescente mercado de notícias exigia a utilização de fontes de informação acessíveis e confiáveis. O noticiário produzido e distribuído pelas agências (e Kaplan aponta a Associated Press como o melhor exemplo) acabou por enfraquecer as diferentes manifestações de jornalismo político-partidário.

Criada em 1848, a AP tinha como missão fornecer, a preços razoáveis, informação factual, livre de controvérsias, de modo a garantir que seus associados 
economizassem dinheiro e evitassem o risco de serem "furados" por seus concorrentes.

Nesse sentido, a Associated Press (AP) cobria todos os eventos importantes da política nacional da época e os relatava despidos de qualquer interpretação, julgamento ou avaliação partidária. Cada jornal estava livre para publicar as notícias a partir dos elementos que melhor retratavam seus partidos favoritos e ignorar a cobertura a respeito dos seus adversários políticos (KAPLAN, 2002:14).

No que diz respeito à democratização da imprensa nos Estados Unidos, Kaplan considera que ela teve início a partir da década de 1870, quando a circulação diária atingiu a marca de quatro exemplares para cada dez domicílios, passando a incorporar mais cidadãos à sua audiência, fazendo com que a circulação da informação assumisse um papel fundamental para a sociedade americana (Ibidem:10).

É nesse período que surge o que Schudson (2010) chama de "ideais profissionais dos jornalistas", nos quais se inserem questões importantes do ponto de vista da prática dessa profissão, com a valorização dos fatos e da imposição de modelos de obtenção e tratamento da notícia. Os jornalistas passam a receber treinamento para que possam relatar os fatos conforme eles acontecessem, a partir de uma sequencia lógica, considerando seus aspectos mais significativos: Quem ou o quê? Como? Quando? Onde? Os editores cobravam rapidez, objetividade e precisão.

Em 1910 os jornais americanos exibiam, em grande parte, uma estrutura administrativa mais elaborada, tendo se transformado em empreendimentos corporativos lucrativos, pagando dividendos a seus acionistas e dando início a grandes conglomerados midiáticos, que acabariam por impor a cultura e o modo de vida americano ao resto do mundo.

Os jornais tinham se tornado grandes negócios, com prédios muito altos no centro da cidade, dúzias de repórteres, grandes patrocínios de celebrações públicas e páginas de publicidade de estabelecimentos comerciais recémcriados. Os jornais expandiram imensamente seu público-alvo neste mercado em crescimento; cada vez mais jornais contavam com uma circulação de centenas de milhares. Consequentemente, os repórteres que escreviam notícias concentravam-se escrever histórias e não em promover partidos (SCHUDSON, 2007:121). 
Ao longo do século XX, notadamente entre os anos 1950 e 1960, a profissionalização no jornalismo norte americano ganhou uma dimensão nunca vista. Segundo Hallin (1994) aquele momento deveria ser considerado como o "alto modernismo" do jornalismo nos Estados Unidos. Os veículos e grupos de mídia passaram por importantes transformações em suas estruturas econômicas, efeito das mudanças que ocorriam na sociedade americana. Nos anos de 1970, a maioria das grandes cidades americanas contava com um único jornal diário. Essa concentração resultou, em parte, do crescimento das cadeias de jornais e de suas políticas de aquisições e fusões, visando, principalmente, ampliar a economia de escala e reduzir a competição.

Já são bastante conhecidas e discutidas as mudanças observadas no jornalismo norte-americano ao longo desses primeiros anos do século XXI, principalmente a constante preocupação em oferecer ao leitor/ouvinte/telespectador a possibilidade de compreender melhor os acontecimentos a partir de uma postura analítica/interpretativa claramente desvinculada de posições partidárias.

O jornalismo mudou significativamente, com uma mistura mais
despreocupada de distanciamento profissional, de diligência analítica - e,
portanto, interpretativa - e de considerações guiadas pelo mercado das
paixões e dos interesses do público, do que no passado imediato. Porém, a
ligação a uma visão em particular do jornalismo - centrado em fatos,
agressivo, enérgico e não-partidário - continua poderosa, praticamente
sagrada, entre a maioria dos jornalistas americanos (lbidem:125).

Da mesma forma, as novas mídias passaram a competir com os jornais diários por leitores e anunciantes, fazendo com que o jornalismo impresso perdesse ainda mais seu status de principal meio de informação e entretenimento junto aos consumidores americanos (o que já havia ocorrido em relação à televisão), apesar de continuar gerando lucros razoáveis às suas empresas.

Atualmente, um novo modelo de jornalismo, chamado de "jornalismo colaborativo" ou "jornalismo cidadão" 20 toma espaço ao jornalismo tradicional,

${ }^{20}$ É o modelo de jornalismo em que o leitor ou usuário deixa de ser um mero receptor e participa, parcial ou integralmente, do processo de produção de determinado conteúdo jornalístico. Nele, o receptor de conteúdo passou a produzir material para as plataformas dos veículos tradicionais. São indivíduos sem formação jornalística que, engajados na ideia de reconhecimento como parte integrante do jornal, passam a participar dos processos de produção e construção da informação. (DORNELLES; LAUX, 2012:236) 
acrescentando novas funcionalidades às plataformas multidimensionais em que se converteram boa parcela dos mais importantes veículos impressos americanos.

\title{
2.3 A IMPRENSA AMERICANA SE TORNA MODELO PARA O JORNALISMO NO BRASIL
}

Se considerarmos que as mudanças estruturais no jornalismo americano que - afastaram da política partidária, transformando-o em atividade nitidamente comercial se iniciaram por volta de 1830, verificaremos que foi necessário mais de meio século para que os jornais brasileiros se aproximassem, ainda que de forma tímida, desse modelo industrial de jornalismo.

\begin{abstract}
O processo de constituição do moderno jornalismo no Brasil se deu em um contexto de sobressaltos e de redefinições político-institucionais, de grandes campanhas, de denúncias plantadas por facções políticas rivais, de rixas, calúnias e escândalos. Foi "popular", no sentido norte-americano do termo, alimentando um primeiro e ainda incipiente empuxo cívico, ao tempo em que consolidava sua face mercantil (CARVALHO, 2012:43).
\end{abstract}

É importante registrar que alguns pesquisadores brasileiros não percebem a influência do jornalismo americano sobre o jornalismo brasileiro antes da metade do século XX, estabelecendo como marco inicial dessa influência a reforma do Diário Carioca, comandada por Pompeu de Souza, em 1950, que teria introduzido naquele jornal novidades importantes como o uso do lead e a adoção de um manual de redação, alterações logo incorporadas pelos demais diários brasileiros.

Mas há indicações bastante precisas de que tanto o lead quanto o manual de redação já eram conhecidos dos jornalistas brasileiros bem antes da reforma promovida por Pompeu de Souza.

No que diz respeito, especificamente, ao manual de redação, Alfredo Vizeu (2007) esclarece que a primazia de sua utilização coube a Gilberto Freyre, no final da década de 1920, logo depois de uma temporada de estudos na Universidade de Baylor (EUA).

Preocupado com a qualidade do jornalismo, [Freire] procura orientar os jornalistas sobre como escrever com correção e clareza, num estilo simples e coloquial. Para isso, usava o placard - uma pequena folha de papel que afixava no mural da redação do jornal $A$ Província, em Pernambuco, em 1929, estabelecendo regras e cuidados no redigir. Esse é o nosso primeiro manual de redação (VIZEU, 2007:1). 
O autor reconhece que, apesar da simplicidade, o documento elaborado por Gilberto Freyre reunia um conjunto de normas que orientavam os jornalistas na produção de seus textos e na relação com os leitores, funções fundamentais de um manual de redação (Ibidem:1).

Quanto ao lead, Nóbrega da Cunha, ainda no início da década de 1940, expõe seus princípios básicos, ressaltando a diferença entre o modelo de construção da notícia utilizado pelos jornalistas americanos, do qual o lead é o elemento fundamental, e a prática adotada até então pelos jornalistas brasileiros que lançavam mão do chamado nariz de cera. E descreve cada um dos elementos que compõem o lead - a regra dos cinco W e um H. (CUNHA, 1941:27)

Portanto, é possível identificar nesses dois casos o interesse que o modelo e as técnicas presentes no jornalismo norte-americano, e que se constituíam em elementos distintivos daquele tipo de jornalismo, já despertavam junto aos jornalistas brasileiros bem antes da reforma do Diário Carioca.

É óbvio que entre a atenção, o interesse e a curiosidade por determinadas soluções e a efetiva utilização desses artifícios há uma enorme distância, circunstância apontada por muitos pesquisadores como suficiente para garantir que o modelo norte-americano só passa a verdadeiramente influenciar os jornais brasileiros depois de 1950.

Ao analisar essa questão, o professor Afonso Albuquerque, da Universidade Federal Fluminense (UFF), destaca a ausência de uma compreensão mais adequada do que teria sido o desenvolvimento histórico do jornalismo americano, o que, segundo ele, leva os estudiosos brasileiros a fazer "inferências simplistas sobre a sua natureza e sua influência sobre o jornalismo brasileiro" (ALBUQUERQUE, 2010:102).

Ele chama a atenção, ainda, para o que considera um papel ativo dos jornalistas brasileiros - e aí ele se refere especificamente aos que trabalhavam no Diário Carioca - no processo de adoção do modelo americano, reinterpretando-o e adequando-o às circunstâncias específicas da sociedade brasileira naquele momento (Ibidem:107). 
Ora, se isso efetivamente ocorreu na década de 1950, como defendem muitos pesquisadores, o que impediria que tivesse se dado, também, no final do século XIX, com os jornalistas brasileiros buscando alternativas viáveis para seus problemas a partir do que faziam os veículos americanos, sem deixar de considerar as especificidades de nossa sociedade àquela altura.

Albuquerque (2010) argumenta que na segunda metade do século XIX o jornalismo americano ainda possuía um forte viés partidário, "ligado a partidos ou a suas facções", o que acabaria por refletir no seu conteúdo e na sua audiência. Essa situação, tomada de forma isolada, inviabilizaria, a priori, nossa tese de que o jornalismo americano serviu de modelo para o jornalismo brasileiro já a partir da segunda metade do século XIX, graças às mudanças estruturais promovidas pela penny press e pelos modelos narrativos difundidos pelas agências de notícias.

Ao defendermos tal posição, levamos em consideração que a ocorrência de mudanças estruturais num determinado modelo jornalístico não está relacionada, unicamente, às convenções textuais (artigos jornalísticos escritos em primeira pessoa e que descrevam os eventos na ordem cronológica), como aponta Albuquerque.

$\mathrm{Na}$ verdade, ao divisarmos mudanças estruturais significativas no jornalismo brasileiro no final do século XIX, levamos em conta outros fatores importantes, que certamente impactaram o campo jornalístico, como os ligados à economia das mídias, com a adoção de novos modelos de gestão e de estruturas de financiamento; a introdução de novas tecnologias; o aumento da circulação dos jornais e a profissionalização da atividade jornalística.

E devemos considerar, também, elementos específicos da construção da narrativa jornalística que certamente passam a definir um novo modelo, como o surgimento da reportagem, o recurso à entrevista, o uso intensivo da ilustração e a adoção de novas pautas, que buscavam aproximar o jornalismo do leitor comum.

Ao pensar as mudanças gráficas e editoriais - nas quais se destaca a inclusão de grandes ilustrações e fotografias, a criação das manchetes de página, a diminuição do formato dos periódicos; de novas fórmulas editoriais, com a introdução de entrevistas, o destaque às reportagens, notadamente as de caráter sensacionalista; 0 isolamento dos textos opinativos dos informativos, entre outros - buscamos, ao mesmo tempo, o sentido dessas inovações. Esse novo jornalismo significou não só a 
conquista de mais leituras, como também a introdução de uma nova leitura (BARBOSA, 1997:89)

Segundo Sodré (1999:275), no Brasil, a imprensa industrial já se achava consolidada no final do século XIX. Os veículos de caráter artesanal subsistiam, apenas, no interior, servindo aos chefes políticos locais. Já nas grandes cidades do país, o jornalismo "ingressara, efetiva e definitivamente, na fase industrial", empresa grande ou pequena, no qual se vendia a informação.

\begin{abstract}
Chega a ser patético o esforço de José do Patrocínio, por exemplo, de fazer de seu Cidade do Rio, em 1887, uma versão tropical do New York Herald. Patrocínio esperava obter dinheiro com o seu jornal, como um trecho de seu discurso de inauguração do diário revela: "um pouco de trabalho, um bocado de esforço, e acharemos o veio da mina. Porque será uma verdadeira mina. Que diabo, não basta ter talento, é preciso também um pouco de senso prático". (LINS DA SILVA, 1991:58)
\end{abstract}

Mas se do ponto de vista de sua organização técnico-administrativa a imprensa brasileira já dispunha de mecanismos e elementos que a credenciavam como uma imprensa industrial, no que diz respeito ao uso dos recursos narrativos os jornais e revistas ainda estavam longe de poderem ser descritos como veículos informativos, se comparados com os que circulavam na Europa e na América do Norte.

Mas as transformações porque passou o país acabaram contribuindo para que se estabelecessem novas formas de relacionamento do jornal com a política, com os seus anunciantes e principalmente com os seus leitores, submetidos a uma realidade que se altera rapidamente na esteira de mudanças econômicas importantes, principalmente com a ampliação da urbanização.

E a vida urbana ganha uma dimensão até então ausente das páginas dos diários e dos semanários brasileiros. As relações se sofisticam e a todo o momento surgem novidades e modismos: o footing na Avenida Central, as visitas às modistas da Rua do Ouvidor, os espetáculos com estrelas internacionais da música e da dança, a paixão pelos esportes que chegam da Europa e arrebatam os jovens da elite.

A cidade intromete-se na imprensa. $O$ crescimento da cidade, a diversificação das atividades econômicas, a ampliação do mercado e o desenvolvimento da vida mundana são incorporados às formas e conteúdos dessas publicações [a imprensa periódica]. Através de novas temáticas, personagens e linguagens, o processo social que transforma a cidade passa também a configurar as publicações (Ibidem: 80) 
O período que vai do final do século XIX até a revolução de 1930 representa uma mudança significativa da imprensa no Brasil, chamada por Sodré (1999) de fase da "grande imprensa" e que se caracteriza pelo aumento nos investimentos das empresas jornalísticas, na aquisição de equipamentos e máquinas mais modernas e no contínuo processo de profissionalização das atividades desenvolvidas pelos diversos grupos que formavam a força de trabalho do jornalismo.

E o mesmo fenômeno pode ser observado na diversidade de leitores que esses veículos passam a atrair regularmente, "além da elite masculina dos políticosdoutores-literatos, outros grupos sociais, como imigrantes, mulheres cultas da elite, camadas intermediárias letradas, professores, escrivães, caixeiros, funcionários burocráticos [..] e outros trabalhadores urbanos" (Ibidem:82).

Do ponto de vista da tecnologia, os jornais promovem uma verdadeira revolução nos equipamentos gráficos, importando máquinas impressoras da Itália, da Inglaterra e da Alemanha, incluindo as primeiras rotativas que permitiam a impressão de até 15.000 exemplares por hora. Além disso, o processo de ilustração dos jornais também se moderniza, com a introdução de novos métodos, levando a uma demanda por profissionais especializados em artes gráficas, tipógrafos e gráficos em geral.

Da mesma maneira, a publicidade se altera significativamente. A necessidade de assegurar os investimentos necessários à manutenção das novas estruturas e do novo modelo de produção da notícia faz com que os anúncios publicitários se tornem mais atraentes e estejam atentos aos interesses de um público que passa ter acesso a mais produtos.

Os antigos anúncios que ofereciam recompensa pela captura de escravos fugidos ou que proclamavam as virtudes de um mestre barbeiro, capaz de fazer sangrias e pequenas cirurgias dão lugar aos "reclames" mais elaborados e que contam, até mesmo, com o talento de poetas consagrados na composição de quadrinhas para vender xarope e fósforos.

Bilac [Olavo] receberia cem mil réis por uma quadrinha proclamando a qualidade de determinada marca de fósforos. [...] Emílio de Menezes redigia anúncios em versos para determinada marca de cerveja; Hermes Fontes forjou soneto destinado a um laboratório que fabricava xarope para a tosse (SODRÉ, 1999:281). 
A leitura diária dos jornais incorpora-se ao cotidiano dos moradores das grandes cidades brasileiras. Ofertados aos gritos por pequenos jornaleiros nas ruas centrais ou expostos em quiosques, livrarias, os jornais passam a fazer parte da paisagem urbana do Brasil no início do século XX, a exemplo do que já ocorria há algum tempo na Europa e, principalmente, nas grandes cidades norte-americanas.

Mesmo tendo ampliado substancialmente sua participação nesse novo ambiente, e assim dado início à consolidação de sua condição de atividade empresarial, os jornais brasileiros do final do século XIX e início do século XX ainda estão longe dos padrões exibidos pelos jornais da Europa e dos Estados Unidos, especialmente no que diz respeito à construção da notícia.

Os textos ainda estão impregnados de uma linguagem pseudoliterária, espalhados em poucas páginas (entre quatro e oito), começando pelo artigo de fundo. Um artigo de "cartola e pince-nez, ar imponente e austero, mas rigorosamente vazio de opinião", na definição de Luís Edmundo citada por Sodré (1999:282).

No que diz respeito à organização visual, chama a atenção a falta de movimento, as colunas alinhadas, sem subtítulos ou manchetes. Os títulos são curtos e não destacam os elementos principais da notícia.

A diagramação torna a leitura de artigos um verdadeiro exercício de paciência, levando o leitor a exasperar-se ao procurar a continuação do texto que lia na página dois e que repentinamente desaparece, tornando a aparecer no rodapé da página cinco. A qualidade da impressão e as tintas usadas deixam marcas enegrecidas nas pontas dos dedos dos leitores, sem contar a textura do papel, áspero e frágil, que se rompe com muita facilidade.

Ao analisarmos todas essas questões, envolvendo a forma e o alcance da imprensa brasileira naquele período, percebemos que, apesar de buscarem na imprensa norte-americana a inspiração para a construção de um jornalismo industrial, parcela considerável dos jornais brasileiros ainda apresentava, nos primeiros anos do século $\mathrm{XX}$, características que os mantinham atrelados aos formatos vigentes na segunda metade do século XIX. 
Isso viria a exigir um grande esforço e mais investimentos para que se alcançasse um padrão razoável tomando como modelo o que havia em outros países.

Já assimilamos, do espírito da imprensa norte-americana, muitas lições, conquanto não as estejamos praticando completamente. Desapareceu da imprensa brasileira, por efeito da influência norte-americana, o artigo de fundo. O que se encontra hoje nos nossos diários com a denominação de editorial, não mais é o clássico artigo de fundo, de sobrecasaca, que era o esteio de um jornal, e morreu, indiretamente, por sugestão da imprensa norte-americana. Foi substituído pelo editorial, mas leve, e pelo comentário ligeiro (CUNHA,1941:18).

Dentre as dificuldades a serem superadas pelo jornalismo brasileiro na virada do século XIX para o século XX a mais complicada, sem dúvida, era a questão financeira. Os veículos passaram a abrir espaço para as reportagens, gênero jornalístico bastante comum no jornalismo norte-americano e que exigia um envolvimento maior do jornalista, empenhado em investigações, pesquisas, entrevistas e levantamentos que tomavam muito tempo e custavam caro.

Eram poucos os veículos que se dispunham (ou tinham condições) de fornecer os recursos necessários à produção de uma boa reportagem. Nóbrega da Cunha (1941) registra a experiência que vivenciou ao ser enviado ao exterior, em 1929, para cobrir pela primeira vez para um veículo brasileiro um concurso internacional de beleza, pelo que recebeu a surpreendente quantia de trinta e cinco contos de réis, algo até então inédito para os profissionais brasileiros.

Tratava-se de um concurso de beleza. Um diretor de jornal, o sr. Assis Chateaubriand, fez-me ir aos Estados Unidos para realizar a reportagem da competição internacional a que comparecia, pela primeira vez, uma sulamericana, por sinal brasileira, srta. Olga Bergamini de Sá. Por esse trabalho, recebi eu trinta e cinco contos de reis, fora as despesas, e este particular é importante (CUNHA, 1941:18).

Ainda segundo Cunha, os Diários Associados gastaram cerca de cem contos de reis e ganharam algo em torno de trezentos contos com o aumento da circulação, da venda avulsa e dos anúncios de seus diversos veículos. E outro tanto, ainda na avaliação dele, pelo aumento do prestígio obtido pela reportagem que se difundiu pelo Brasil inteiro e em alguns países da América do Sul.

Mas a instabilidade econômica que se instalou no Brasil após a crise de 1929 levou as empresas jornalísticas a restringirem essas iniciativas, muito embora já 
tivessem percebido que aquele modelo representava a melhor forma de fazer o jornalismo se transformar numa atividade comercial sustentável e lucrativa.

Ainda seriam necessárias mudanças mais profundas nas estruturas econômicas e políticas do País para que o jornalismo avançasse no sentido de se transformar numa importante atividade econômica, ao mesmo tempo em que ampliava sua capacidade de influenciar nos campos político e social.

E essas mudanças começam a surgir com o novo País que emerge da revolução de 1930, sob o comando de Getúlio Vargas. Amparado numa eficientíssima estrutura de propaganda, Vargas criará boa parte das condições estruturais que vão permitir ao jornalismo brasileiro avançar em direção a um novo modelo empresarial, muito mais eficiente e dinâmico, capaz de utilizar-se de todos os recursos disponíveis para manter seu protagonismo e sua capacidade de influenciar nas mais importantes questões que se colocavam diante de nossa sociedade. 


\section{CAPÍTULO III - O BRASIL MUDA. E, COM ELE, MUDA O JORNALISMO}

Quando os revolucionários gaúchos amarraram seus cavalos no obelisco da Avenida Central, no Rio de Janeiro, em outubro de 1930, o Brasil dava início a uma das mais significativas fases de mudanças de sua história, que atingiram praticamente todos os setores da vida nacional, desde a ordem política, passando pela economia e chegando ao campo do jornalismo nas suas mais diferentes vertentes.

A implantação da República, em 1889, significou o deslocamento do poder (ou pelo menos da luta pelo poder) da Corte para as diferentes regiões do País. O regime federativo criado a partir da constituição de 1891 levou ao fortalecimento das lideranças políticas regionais, ao impedir a existência de partidos políticos nacionais.

Nesse contexto, os grupos políticos ligados aos setores mais fortes da economia em cada estado tornaram-se praticamente hegemônicos e passaram a conduzir a política nacional a partir de seus interesses específicos. Assim, os interesses regionais acabavam impondo-se aos interesses nacionais e que eram, na verdade, os interesses dos estados mais importantes economicamente.

Alguns autores chegam mesmo a definir e a apontar a existência de interesses oligárquicos que mantinham o controle da economia e da política. Mas Fonseca (2012) chama a atenção para o fato de que essa oligarquia não reunia, apenas, os interesses dos agricultores, como se costuma pensar.

Segundo ele, o fenômeno oligárquico pode estar associado a qualquer classe social, bem como a diferentes organizações. Por isso, ele acredita tratar-se de um equívoco quando a historiografia brasileira normalmente aponta uma relação necessária entre a oligarquia e o setor agrário, consagrando a ideia de que no Brasil da Primeira República o poder esteve nas mãos de uma "oligarquia rural". 
$\mathrm{Na}$ verdade, identificar a existência de outras formas de expressão do poder no Brasil naquela época é fundamental para que possamos entender as mudanças porque passaria o País após a revolução de 1930.

$\mathrm{Na}$ ausência de partidos nacionais, os Partidos Republicanos de cada estado tendiam a congregar os diversos segmentos de suas elites, urbanas ou rurais, amalgamando em uma mesma legenda vasta gama não de interesses econômicos, mas de lideranças intelectuais (bachareis, catedráticos, padres, militares) (FONSECA, 2012:848).

O apoio à revolução promovida pela Aliança Liberal não vem somente de uma oligarquia rural dissidente, mas também de setores ligados à produção industrial e que acabariam por trazer a questão da industrialização para o centro da discussão econômica brasileira, o que se tornaria crucial para o desenvolvimento do jornalismo informativo.

Isso é facilmente comprovado quando observamos os índices de crescimento dos diversos setores de nossa economia durante a década de 1930, notadamente o período que vai de 1933 a 1939, com grande destaque para o crescimento industrial.

A indústria de transformação cresceu 11,2\% anuais entre 1933-39. No mesmo período, a agricultura não cresceu mais do que $2 \%$ ao ano. Da mesma forma há, nesse momento, uma mudança significativa na pauta de importações, com destaque para o aumento da importação de bens de capital, insumos essenciais para a indústria, que chegou a 17,9\% (Ibidem:849).

Portanto, a revolução de 1930 e a chegada de Vargas ao poder têm uma evidente ligação com as mudanças que o País precisava fazer para ajustar-se às novas condições sociais, políticas e econômicas que se instalam no Brasil a partir da década de 1920, atingindo o máximo de tensão após a crise mundial de 1929.

O governo de Vargas rompeu a relação de forças que havia no País desde o Império, abrindo espaço para o surgimento de novos centros de poder, o que incluía uma nova classe de produtores industriais e os primeiros sinais de uma classe média urbana, ávida a consumir bens e serviços, dentre eles a notícia.

Fonseca (2012) sintetiza, assim, as principais mudanças observadas a partir da chegada de Vargas ao poder. 
[Vargas] incitou uma transformação estrutural na economia, ao deslocar seu "centro dinâmico" para a indústria e para o mercado interno, com o investimento privado e os gastos governamentais substituindo as exportações como variáveis determinantes da demanda agregada. Marcase, assim, a passagem do modelo agroexportador para o processo de substituição de importações (Ibidem:844).

O País que começa a tomar forma a partir da revolução de 1930 vai reunir as condições essenciais para que o jornalismo amplie sua capacidade de influenciar a opinião pública, o que é logo percebido pelo novo regime, preocupado em mobilizar os diferentes segmentos sociais em torno das mudanças propostas por Vargas.

Num primeiro momento, a euforia pela possibilidade de construir uma nova realidade faz com que boa parte da imprensa se alinhe aos revolucionários, divulgando as medidas emergenciais, incentivando o povo a colaborar com as novas autoridades, denunciando os desmandos do antigo regime. Ao mesmo tempo, os jornais considerados a favor do governo deposto foram depredados por populares.

$\mathrm{Na}$ edição das 17 horas do dia 24 de outubro de 1930, O Globo dedica toda a primeira página à vitória das forças rebeldes de Getúlio Vargas e à prisão do presidente deposto Washington Luís. Na descrição de $\mathrm{O}$ Globo, "a revolução empolgou o País de Norte a Sul" e registra a homenagem da população ao jornal, que compareceu à redação para comemorar a vitória da revolução.

Um detalhe interessante: a $3^{\text {a }}$ edição de $O$ Globo naquela noite (20 horas) traz na capa uma foto ampliada do Presidente deposto, Washington Luís, dentro de um carro, sendo conduzido ao Forte de Copacabana, de onde seria depois mandado ao exílio. A foto é nítida e de boa qualidade e vale pelo flagrante. Essa foto exclusiva foi fruto da obstinação e da persistência de um dos repórteres que cobriam os acontecimentos para o jornal: o jovem Roberto Marinho, que manteve vigília durante horas à porta do Palácio Guanabara até perceber a saída do presidente e atirar-se à frente do veículo, que reduziu a velocidade o suficiente para que ele fizesse o instantâneo.

Ainda nessa mesma edição, $O$ Globo noticia os ataques aos jornais $A$ Crítica, $A$ Noite, e $A$ Notícia, cujo cofre foi levado por populares e entregue, vazio, à redação de $O$ Globo. 
Para a imprensa brasileira, o movimento revolucionário de outubro de 1930 marca o início de um período especialmente turbulento, com o governo tentando, de todas as formas, controlar a influência cada vez maior que o jornalismo exercia num país que iniciava seu processo de industrialização, com todas as dificuldades que tal mudança implicava, principalmente com relação aos novos arranjos sociais e o alcance da ação política.

Desde o início da década de 1920, o País experimentara uma sequência de movimentos, tentativas de golpe, quarteladas, indicando que já há algum tempo estaria em curso um processo irreversível de confronto entre as diversas forças que compunham o cenário político brasileiro.

\begin{abstract}
O Brasil, de fato, havia mudado, enquanto mudava o jornalismo brasileiro. As aventuras de empresários e seus negócios de risco, aquilo que caracterizou o "americanismo à brasileira" nas primeiras décadas republicanas, não encontrara solução institucional adequada, e o Estado se avultava como tutor de uma sociedade que, sozinha, não conhecera a ordem e a prosperidade. Getúlio Vargas já se pusera no horizonte das alternativas modernizadoras do país (CARVALHO, 2012:210).
\end{abstract}

A proximidade da luta acelerou, na visão de Sodré (1999) as transformações que atingiriam a imprensa empresarial, preparando-a para os tempos difíceis que viriam, mas que ao final criariam as condições para a consolidação de uma nova forma de fazer jornalismo e que tinha em veículos como o Diário Carioca, O Jornal, A Noite e $O$ Globo, o seu melhor exemplo. Alguns desses veículos, já na segunda metade da década de 1920, se apresentariam como precursores dos grandes grupos midiáticos que entrariam em cena alguns anos depois.

Ao final do seu primeiro período como governante, a maior parte dele como ditador, Getúlio Vargas teria contribuído para o surgimento de uma "sociedade urbana de massas", como assinala Lira Neto (NETO, 2013:490) arranjo essencial para que a imprensa no Brasil alcançasse uma nova dimensão, transformando-se em elemento fundamental na disputa de espaço em torno do poder e atingindo a condição de importante setor produtivo, com o surgimento e o desenvolvimento de nossos primeiros conglomerados midiáticos. 


\subsection{SÃO MUITAS AS MUDANÇAS E A REPERCUSSÃO NA IMPRENSA É IMEDIATA}

O IBGE (Instituto Brasileiro de Geografia e Estatística) estima que em 1930 a população brasileira atingira a marca dos 30 milhões de habitantes. Os números exatos deveriam ser obtidos por meio do censo populacional daquele ano, que acabou não ocorrendo por conta das condições políticas enfrentadas pelo país. ${ }^{21}$

A imigração, que tinha contribuído fortemente para o aumento populacional a partir de 1887, perde importância diante do crescimento natural da população brasileira, demonstrando que no Brasil o fluxo de estrangeiros não teve, para o desenvolvimento da imprensa, o mesmo papel e a mesma importância que teve em outros países americanos, principalmente nos Estados Unidos, onde pesquisadores como Schudson identificam no movimento migratório uma das causas para a ampliação do alcance da imprensa, ainda nas primeiras décadas do século XIX ${ }^{22}$.

De qualquer forma, no Brasil dos anos de 1930, as mudanças no perfil populacional indicavam que estava em curso um acelerado processo de urbanização que responderia por alterações significativas na economia o que, por sua vez, teria reflexos importantes na atividade empresarial jornalística.

Houve também mudanças expressivas em setores e atividades consideradas essenciais para o desempenho da imprensa comercial. A educação formal avançou de forma consistente, fazendo com que um contingente considerável de novos leitores passasse a consumir regularmente as notícias e demais produtos ofertados pelos jornais.

De nação essencialmente agrária e semicolonial, o Brasil iniciara um processo de industrialização crescente, que se intensificaria nos decênios seguintes. Os setores da manufatura mais tradicional assistiram à expansão do parque industrial de base, representado em particular pela área metalmecânica. Grandes institutos de pesquisa e empresas estatais, como a Companhia Siderúrgica Nacional, a Companhia Vale do Rio Doce e a Fábrica Nacional de Motores, surgiram sob o influxo da política desenvolvimentista do Estado Novo (NETO, 2013:490).

${ }^{21}$ Estatísticas do Século XX. Instituto Brasileiro de Geografia e Estatística, 2006

${ }^{22}$ Schudson (2010) aponta os jornais como importante meio de integração cultural e de domínio da língua inglesa para os imigrantes que chegavam aos Estados Unidos no final do século XIX. 
Mas sem dúvida, a grande mudança ocorrida na sociedade brasileira a partir de 1930, e que teria repercussão na atividade jornalística seria a consolidação do Estado como protagonista do processo político, ocupando todos os espaços disponíveis, controlando a atividade das empresas do setor, distribuindo benesses e punindo aqueles que se posicionavam contrariamente aos seus interesses. No que diz respeito à imprensa, ao longo desse período específico da história política brasileira, consolida-se a implantação e a utilização da propaganda por parte do governo, prática que se observava em várias regiões do mundo naquele momento, assoladas por governos nacionalistas e ditatoriais.

Para os revolucionários de 1930, a questão da liberdade de expressão deveria ser tratada com prioridade, tendo em vista que nos últimos anos da República Velha a censura à imprensa foi um expediente comum, ao qual recorreram os governos de Artur Bernardes e Washington Luiz.

Os homens que engendravam a Revolução de 1930 eram as vozes mais
frequentes contra esse estado de coisas. Em setembro de 1926, por
exemplo, os chefes da Coluna Prestes incluíram em suas aspirações "a
revogação da Lei de Imprensa", segundo atesta uma carta tornada pública
por Batista Luzardo, porta-voz da revolução na Câmara dos Deputados
(COSTELLA, 1970:97).

Por isso mesmo, havia uma expectativa de que, vitoriosa a revolução, a imprensa pudesse atuar de maneira livre, sem qualquer tipo de interferência ou controle por parte do novo regime. Mas não foi isso o que ocorreu. O regime que se instala no País é marcado por seu caráter totalitário, sem a presença das instituições democráticas e com o uso indiscriminado da censura e da força.

Um dos primeiros jornais a sentir o peso da mão da nova ordem política foi o Diário Carioca. Fundado em 1928 com o intuito de denunciar os desmandos do governo Washington Luís, o jornal foi um dos veículos que logo viriam a aderir ao movimento revolucionário que levaria Getúlio Vargas ao poder, o que não impediu que viesse a ser alvo da truculência dos grupos que gravitavam em torno do ditador.

Em 1932, depois de insistir na defesa da volta à constitucionalidade, o jornal foi invadido por soldados do Exército, fardados, que destruíram tudo o que encontraram pela frente, agredindo jornalistas e gráficos e confiscando uma edição inteira pronta para circular. 
Suas páginas não cansavam de exigir eleições livres para uma Assembleia Constituinte, com vista à elaboração de uma nova Carta Magna para o Brasil. Por isso, os três caminhões parados em frente à sede do jornal àquela hora da noite, com soldados ostensivamente armados, não pareciam indicar uma visita de cortesia (NETO, 2013:15).

O Diário Carioca foi um jornal inovador e serve de referência quando analisamos as mudanças promovidas pelos veículos de imprensa no Brasil a partir dos anos 1920. Jornal de pequena tiragem, quando comparado aos maiores jornais da época, como o Correio da Manhã ou o Diário de Notícias, exercia, contudo, grande influência sobre a opinião pública e sobre os demais veículos.

Inovações importantes, como a modernização de sua estrutura administrativa, de suas características gráficas e de seu estilo editorial fizeram com que o Diário Carioca, ou $D C$, como ficou conhecido, se antecipasse aos demais jornais de seu tempo, estabelecendo novos parâmetros que indicavam claramente que o jornalismo brasileiro passava por importantes mudanças estruturais.

O lide e sublide estavam lá no DC [Diário Carioca]. As oito colunas. A
pirâmide invertida. Os títulos criativos, debochados, em três linhas, puro DC.
Os títulos com dois pontos. Ou sem verbo. Os títulos-legenda. As siglas JK,
J-J e Jan-Jan, criações de Pompeu de Souza. As primeiras páginas azuis.
O manual de redação, outra criação ou legado de Pompeu à imprensa
brasileira. As misses. O colunismo, o jornalismo literário, o suplemento
infantil, o suplemento feminino, o apoio ao sindicalismo nascente no país,
ao funcionalismo em sua angustiosa campanha por melhores salários, a
busca de interação com o leitor, os prêmios, os concursos, a carioquice
brincalhona, uma incipiente "cobertura de cidade". As fotos recortadas, os
filminhos, as fotos de página inteira, tudo DC. Em cores. Em dado momento,
até fileiras de quadrinhos em cores (COSTA, 2011:19).

\subsection{MUDAM OS JORNALISTAS}

Outra mudança significativa, iniciada com a virada do século e que se consolida a partir da década de 1930, a qual nos interessa enquanto indicativa de mudanças estruturais no jornalismo brasileiro, são percebidas no comportamento e na ação dos profissionais da área.

As diferentes atividades exercidas pelos jornalistas, assim como a diversidade de meios de comunicação nos quais atuam, representam uma dificuldade natural na definição, com clareza, do que venha a ser a "atividade jornalística", bem como do próprio termo "jornalista". 
A realidade social na qual se insere o jornalista responde por grande parte de sua atuação e de sua identidade, dificultando ainda mais a tarefa a que alguns pesquisadores se propõem de estabelecer os limites e o papel social da atividade.

O jornalista é, ao mesmo tempo, funcionário de uma empresa capitalista, responsável pela produção de uma mercadoria (a notícia) submetida às leis de mercado; e uma espécie de contra-poder, cuja autoridade, delegada pela sociedade, Ihe permite fiscalizar as instituições em nome do interesse público. O choque entre essas diferentes visões condiciona uma identidade profissional conflitante (PEREIRA, 2004).

Ainda no período doutrinário da imprensa brasileira, não havia o jornalista. No Brasil, a exemplo do que ocorreu no resto do mundo, o jornalismo surgiu primeiro e só muito tempo depois apareceu o jornalista. Os primeiros jornais, de duração efêmera e de ideias rígidas, eram feitos por "brasileiros amigos da nação e da pátria" como declararam Gonçalves Ledo e Januário da Cunha Barbosa, redatores do Revérbero Constitucional Fluminense, fundado em 1821 e que se tornaria, segundo Sodré (1999:53), "o órgão doutrinário da Independência brasileira”.

Ledo cursou medicina em Coimbra, sem, no entanto, concluir o curso. Regressou ao Brasil por causa da morte do pai e terminou por obter um emprego público. Barbosa foi padre, poeta e escritor, além de professor de filosofia. Eram os únicos responsáveis pelo jornal, onde se encarregavam de redigir artigos de cunho doutrinário que pregavam a independência do Brasil. Ledo e Barbosa são exemplos do perfil dos que faziam jornalismo durante a primeira fase da imprensa brasileira.

Fazer jornalismo naquele momento (nas primeiras décadas do século XIX) era, exclusivamente, um artifício usado por profissionais liberais e homens de letras para desencadear ações políticas, sem nenhum caráter de atividade profissional. A maioria dos jornalistas desse período só viria a ser reconhecida como "jornalista" muito tempo depois, quando a profissão já adquirira certo prestígio, no início do século $X X$.

O exercício do jornalismo em nosso país foi feito, durante todo o século XIX, como fonte de ascensão social por intelectuais que o utilizavam como trampolim para fazer carreira na burocracia estatal ou para influir no cenário político. O paradigma dessa simbiose entre jornalismo, política e literatura pode ser buscado em Rui Barbosa, personagem emblemático da história nacional, que atuou como jornalista no início de sua vida pública, retornando ciclicamente a essa atividade nos interregnos de seus embates políticos ou jurídicos (MARQUES DE MELO, 2003:296). 
Um jornalismo feito por literatos que se confunde com literatura. Assim Sodré (1999) descreve a atividade dos jornalistas brasileiros "na alvorada do século XX", responsáveis por uma imprensa "anêmica, clorótica e inexpressiva, (...) coisa precária, chã, vaga, morna e trivial” (SODRÉ, 1999:282).

Esses jornalistas produziam um noticiário escrito de maneira pretensiosamente difícil, "empolada", e os fatos e informações não eram de interesse geral ou não se achavam apresentados de forma objetiva. Era o jornalismo de gabinete. Poucos jornalistas se aventuravam nas ruas em busca da informação, da notícia, da novidade.

A necessidade de aproximar o jornal do público-leitor, preocupação que surge no início do século $X X$, vai repercutir na maneira como os jornalistas se comportam, determinando mudanças nas relações que mantinham com as fontes e na própria identidade profissional. Os jornalistas saem das redações e vão para as ruas, buscando as pessoas comuns e a notícia.

São, em sua maioria, segundo Barbosa (2000) jovens estudantes que encontram no jornalismo uma maneira de conseguir prestígio e algum dinheiro. Além disso, a atividade jornalística era o primeiro passo para ingressar na política e ocupar cargos na máquina estatal. A maioria absoluta é de estudantes de Direito, seguidos pelos de Medicina, pelos que cursavam a Escola Militar (responsável pela formação de novos oficiais para o Exército) e por alunos dos cursos de Engenharia, além de secundaristas que fazem o curso de Humanidades do Colégio Pedro II, no Rio de Janeiro.

Outra característica interessante desses jornalistas no início do século XX é que a maioria passa a exercer a profissão entre os 16 e os 22 anos de idade. Mais da metade dos que atuam em jornais cariocas são originários de outros estados. Iniciam-se na profissão como revisores ou repórteres trabalhando em mais de um jornal.

Ao descrever o perfil dos jovens que ingressam no jornalismo no início do século XX, Marialva Barbosa estabelece de que maneira eles constroem uma identidade de classe que acaba por, invariavelmente, reproduzir o discurso das classes dominantes. 
Independentemente de sua condição de classe, esses jovens intelectuais acadêmicos ocupam uma posição no interior da estrutura social que definirá o próprio habitus de classe do grupo: são jornalistas com o poder de nomeação que a profissão confere. Para ocupar essa posição é fundamental estar inserido no próprio academicismo, tendo adquirido a visão de mundo, o comportamento e as prerrogativas que se espera de um bacharel. Essa característica dá a eles o material simbólico necessário para veicular o pensamento da classe dominante (BARBOSA, 2000:78).

Mesmo aqueles que não fazem parte da chamada "classe dirigente" acabam legitimados para o exercício do jornalismo a partir das relações que construíram ao passar pela academia. Essa relação e essa participação no campo intelectual é que vão fazer com que os jornalistas mantenham-se, de alguma forma, próximos aos interesses dos que estão no poder (lbidem:79).

Para Traquina (2008:34) o processo de profissionalização dos jornalistas seguiu uma tendência histórica, incentivada pelo processo de industrialização e urbanização no século XIX. O que os jornalistas buscavam ao profissionalizarem-se era obter maior autonomia e liberdade e alcançar um estatuto social parecido com os de médicos e advogados. Traquina aponta, ainda, a profissionalização dos jornalistas como um dos processos fundamentais que marcaram a evolução da atividade jornalística.

O surgimento do repórter leva à construção de uma imagem que passa a ser reconhecida como típica do profissional do jornalismo. E são os próprios jornalistas que se encarregam de difundir essa visão glamourizada do repórter que está sempre atento às novidades, em busca de informações e personagens, pronto para levar às páginas dos jornais a realidade das ruas. Imagem que acaba por se estender aos demais profissionais que atuam no jornalismo.

\footnotetext{
A ideologia do profissionalismo defende que o praticante deveria não só ter independência e autoridade, mas também uma "identidade profissional" que tenha um impacto no "pensamento e comportamento através do desenvolvimento de ideologias profissionais distintas" (Philip Elliott 1972:311). Como escreve Bourdieu (1996:11): "Cada profissão produz uma ideologia profissional, uma representação mais ou menos idealista e mítica de si mesma" (TRAQUINA, 2008:22).
}

O repórter transformou-se numa "personagem singular", na descrição de Carvalho (2012), que contribuiu enormemente para fixar no imaginário popular a imagem de um novo tipo de imprensa, cujas características fundamentais seriam o profissionalismo e a modernidade. 
O repórter deveria ser atento, ágil, pronto a identificar um virtual drama urbano e transformá-lo em manchete. Deveria também moderar os rituais da boemia, as demoradas rodas nos cafés e a bebida alcóolica, que afinal, se opunham ao etos profissional em formação. Durante o dia, passara a consumir refeições ligeiras ao balcão, de costas para a rua, com o que diminuía o tempo de descanso e disfarçava a modéstia do consumo (CARVALHO, 2012:49).

Apesar de pagar pouco ${ }^{23}$, a profissão de repórter compensava porque abria outras possibilidades de ampliar os ganhos, principalmente no serviço público. Muitos desses repórteres tinham uma formação acadêmica e buscavam utilizar o prestígio da atividade nos jornais para construir relações que lhes permitissem ingressar na política ou na diplomacia.

Foi o que tentou o jovem repórter Paulo Barreto (que seria imortalizado com o pseudônimo de João do Rio): procurou o próprio Barão do Rio Branco, em Petrópolis, para pedir-Ihe uma vaga na embaixada brasileira na Colômbia, pedido educadamente negado pelo Barão.

Depois de afirmar que as vagas para a missão na Colômbia estavam preenchidas e ser "indispensável" o concurso público para a carreira diplomática, o barão despachou o jovem pretendente, que por ser gorducho e amulatado estava bem distante do tipo garboso preferido pelo chanceler para povoar o Itamaraty (RODRIGUES, 2010:41).

O modelo de organização utilizado pelos jornais da época estabelecia uma divisão de tarefas por setores que englobavam o noticiário local e as notícias que chegavam pelas agências de notícias (o chamado serviço telegráfico) e que tratavam de eventos ocorridos no exterior ou em outros estados do país.

As "notícias locais" eram obtidas por repórteres que peregrinavam por repartições públicas, delegacias de polícia, hospitais, pelo fórum, além da Câmara dos Deputados, do Senado e da Câmara de Vereadores. Esses ocupavam as posições mais baixas na hierarquia da profissão, logo abaixo dos editores, dos secretários de redação e dos diretores.

Havia, ainda, repórteres especializados em cobrir atividades esportivas e espetáculos teatrais. Assim, a partir desse contingente heterogêneo, passa a ser

${ }^{23}$ Maria Alice Carvalho (2012), ao traçar o perfil do repórter do início do século XX registra que "seu salário, afinal, não avançava além dos 150 mil réis", valor cujo poder de compra pode ser avaliado a partir da comparação com o preço de uma xícara média de café com pão torrado que custava, no Rio de Janeiro, cerca de 500 réis. 
possível construir um noticiário variado, com destaque para os fatos de maior apelo emocional, no melhor estilo do fait divers: assassinatos, crimes passionais, desastres e outros dramas do dia a dia que se transformavam em notícia pelas mãos dos repórteres.

Deslocando-se de trem ou bondes para conseguir as notas da reportagem, desempenham um trabalho que é eminentemente externo à redação. Observando o que está ao seu redor escrevem, algumas vezes, excelentes crônicas do cotidiano que reproduzem a vida da cidade. (...) Depois da peregrinação, já ao final da tarde regressam à cidade "para passar a limpo as notas e entregá-las ao secretário". No dia seguinte, na coluna "Pelos Subúrbios" aparecem as suas descrições (BARBOSA, 2000:192).

O processo de profissionalização de qualquer categoria obedeceria a uma sequência de eventos, como aponta Wilensky (WILENSKY apud TRAQUINA, 2008:21). Dentre vários outros, ele destaca o trabalho em tempo integral, o estabelecimento de procedimentos de treino e seleção, a formação de associações profissionais e a elaboração de um código de ética.

Ainda na primeira metade do século $X X$, dois desses fatores teriam contribuído para alterar, definitivamente, o perfil profissional dos jornalistas no Brasil e a percepção da sociedade a respeito dessa categoria: a fundação de uma entidade de classe, a Associação Brasileira de Imprensa (ABI) e a criação dos primeiros cursos superiores de jornalismo.

É o que defende a socióloga Alzira Alves de Abreu (1998), ao analisar o processo de profissionalização da atividade jornalística no Brasil e as mudanças que este processo provocou no próprio campo do jornalismo. Ela pontua que este fenômeno surge como uma exigência do mercado, a partir do crescimento dos meios de comunicação de massa e o desenvolvimento da indústria cultural.

E conclui dizendo que os indicadores formais de verificação do grau de profissionalização estavam preenchidos, "com a existência de uma associação $(A B I)$, regras de conduta codificadas e uma formação específica que permite controlar o acesso à profissão" (ABREU, 1998:8).

No caso da $A B I$, a contribuição para a construção de uma identidade profissional se dá na medida em que, pela primeira vez, os jornalistas buscam o consenso em torno de questões fundamentais para a sociedade, tendo a 
oportunidade de expressarem suas posições e visões de mundo livres da influência dos donos de jornal.

Por meio da $\mathrm{ABI}$, a opinião e o posicionamento político passam a ser dos jornalistas e não dos jornais. Assim, eles obtêm o reconhecimento do restante da sociedade como um grupo que desempenha uma função fundamental para a garantia e defesa da democracia, papel que os próprios jornalistas assumem como sendo a sua "missão" e que irão se esforçar para cumprir.

\subsubsection{A Associação Brasileira de Imprensa e a construção da identidade profissional dos jornalistas brasileiros}

Segundo Traquinq (2004:81), o processo de legitimação e de reconhecimento do campo profissional do jornalismo passa, necessariamente, pela formação de associações e sindicatos a partir do século XIX, principalmente nos Estados Unidos $^{24}$ e na Europa. Esse processo envolveu, ainda, o estabelecimento de cursos superiores e de códigos de ética e de outros instrumentos legais que vão regular a atividade profissional dos jornalistas.

No Brasil, as primeiras tentativas de criar uma entidade que congregasse os jornalistas ocorreram ainda na primeira década do século XX. Mas foi com a chegada de Getúlio Vargas ${ }^{25}$ ao poder que os jornalistas obtiveram os recursos necessários para consolidar a Associação Brasileira de Imprensa - ABI como uma entidade importante, não só do ponto de vista da proteção e do apoio ao exercício da profissão, bem como da projeção social da categoria e da sua capacidade de influenciar as questões mais relevantes para a sociedade da época.

Criada em 1908 (há exatos cem anos após a publicação do primeiro jornal brasileiro) a Associação Brasileira de Imprensa nasceu com o objetivo de estimular e valorizar a profissão de jornalista, num momento em que a imprensa passava por mudanças significativas, com o avanço tecnológico definindo novas formas de

${ }^{24}$ A primeira instituição destinada a congregar jornalistas nos Estados Unidos, o Washingtons's Correspondent Club, data de 1867.

${ }^{25}$ Getúlio Vargas destinou os recursos necessários à construção do edifício-sede da $A B I$ (quatro milhões de cruzeiros), no Centro do Rio de Janeiro. Por essa iniciativa, recebeu o título de sócio honorário da Associação, o que causou enorme polêmica junto aos jornalistas que consideravam Vargas indigno do título, por haver perseguido e censurado a imprensa. 
produção do jornal, valorizando a especialização e a divisão de tarefas (LENE, 2013:19).

A criação da $\mathrm{ABI}$ foi uma iniciativa do jornalista Gustavo de Lacerda, preocupado em defender a liberdade de expressão e também em garantir o mínimo de dignidade àqueles que exerciam a profissão, por ele chamados de "proletários intelectuais" e que por isso mesmo estavam sempre necessitando de ações assistencialistas, como empréstimos, pagamento de remédios, auxílio funeral.

Nascido em 1854, na cidade catarinense de Desterro, Gustavo de Lacerda era uma figura polêmica. Socialista, pregava que os jornais não deveriam constituirse em empresas lucrativas e que teriam, antes de tudo, que exercer uma missão social relevante, funcionando como cooperativas.

Apesar da saúde frágil, Lacerda mantinha uma atividade política intensa, tendo estimulado a fundação do Centro Operário Radical, cuja reivindicação principal era a implantação de uma reforma agrária e o fim de monopólios e privilégios. Além disso, foi um dos fundadores do Partido Socialista Coletivista e incentivou a criação do sindicato dos linotipistas, que viria a ser o primeiro sindicato organizado no Rio de Janeiro.

$\mathrm{Na}$ condição de jornalista, Lacerda sempre se preocupou em noticiar questões que envolviam conflitos sociais. Foi assim que cobriu manifestações e greves, como as dos carroceiros e cocheiros do Rio de Janeiro, que lutavam contra a implantação de exigências desmesuradas por parte da prefeitura da cidade.

Gustavo de Lacerda morreu poucos meses depois de fundar a Associação Brasileira de Imprensa em decorrência de complicações causadas, principalmente, pela desnutrição crônica. A versão de que ele teria sido internado num quarto particular da Santa Casa de Misericórdia do Rio de Janeiro é contestada por Moacir Pereira (PEREIRA, 2008:36), que garante que Lacerda morreu numa enfermaria daquele hospital, onde havia sido internado na condição de indigente.

Lacerda, aos 50 anos, era um homem doente. Sem trato e ganhando pouco, via chegar o fim da vida sem ter sua velhice assegurada. Meses após fundar a $A B I$, foi internado como indigente e por desnutrição na Santa Casa de Misericórdia (LENE, 2013:23). 
A morte de Lacerda, ocorrida no dia 4 de setembro de 1909, foi noticiada em quase todos os jornais da época, dos quais recebeu homenagens por seu "amor à profissão e por sua luta em torno da união dos jornalistas", principalmente pela fundação da Associação. Mesmo assim, foi enterrado em cova rasa no cemitério São João Batista o que, segundo Pereira, "revela a mais completa desumanidade dos colegas e dos diretores de O Paiz' (Ibidem:24).

Para Edgar Morel, a causa mortis de Lacerda registrada em sua certidão de óbito, arteriosclerose, não é verdadeira. Para ele, Lacerda morreu de desnutrição, fome (MOREL apud PEREIRA, 2008:36).

Por conta de suas origens ou de suas aspirações sociais, parcela considerável dos jornalistas da época mantinha um preconceito em relação às atividades associativas e aos movimentos reivindicatórios por melhores salários e condições de trabalho. Essas iniciativas eram vistas como "coisa de trabalhadores braçais" e que não ficavam bem para intelectuais. Daí a enorme dificuldade que a associação teve em mobilizar os profissionais para que unissem forças em torno dos próprios interesses.

No encontro em que foi fundada a $A B I$, no dia 7 de abril de 1908, estiveram presentes, apenas, oito jornalistas. Eles se reuniram numa acanhada sala emprestada pela Caixa Beneficente dos Empregados do jornal O Paiz e decidiram que os estatutos da nova associação teriam como modelo os estatutos da Associação Sindical Profissional dos Jornalistas Republicanos Franceses, instituição criada em 1881, e da Associação Sindical da Imprensa Estrangeira, de 1879 (PEREIRA, 2008:36).

Ao longo do século $X X$, a $A B I$ se consolida como entidade representativa dos jornalistas com o propósito de promover a união desses profissionais em torno de questões fundamentais, como a liberdade de imprensa e a luta pelo reconhecimento do importante papel social do jornalismo e que terá repercussão significativa no processo de construção de uma identidade de classe, tarefa de imensa complexidade, se considerarmos as características da atividade desempenhada pelos jornalistas e a maneira como a encaram. 
Em geral, os jornalistas atribuem, a si mesmos, o papel de "servidores do público", ou mais ainda de "cães de guarda" (watch dogs - expressão muito apreciada pelos jornalistas norte-americanos), vigiando os demais poderes (já que eles se consideram o Quarto Poder) e cumprindo um papel fundamental para a manutenção do sistema democrático e das liberdades individuais.

\begin{abstract}
Segundo a cultura profissional, essa comunidade é de crentes que cumprem o serviço em uma dedicação total à profissão, cujo lado sagrado envolve: longas e irregulares horas de trabalho em que deixa de haver uma distinção entre a esfera da vida privada e a profissional, os evidentes perigos que os profissionais possam enfrentar, incluindo o de vida, a natureza altruística (devoção ao próximo) e mesmo nobre das suas responsabilidades sociais (TRAQUINA apud LENE, 2013:22).
\end{abstract}

Em perfeita sintonia com essa imagem construída pelos próprios jornalistas em torno da profissão, a $A B I$ terá atuação destacada em momentos decisivos da nossa história ao longo do século XX, como no movimento pela criação da Petrobrás ( $O$ petróleo é nosso ${ }^{26}$ ) e durante o processo de redemocratização do país, iniciado com o projeto da lei de anistia que foi elaborado em conjunto com a Ordem dos Advogados do Brasil - OAB e promulgado em 1979. E, ainda, no pedido de impeachment do presidente Fernando Collor de Mello, em dezembro de $1992^{27}$.

Além de cumprir importante papel no cenário político-institucional do país, consolidando-se como uma instância legítima nas lutas sociais que sacudiram o Brasil ao longo do último século, a Associação Brasileira de Imprensa dedicou-se, também, a pleitear melhores condições de vida para os profissionais do setor, o que resultou, em alguns casos, em distorções e privilégios injustificáveis numa sociedade em que a maioria dos trabalhadores tinha dificuldade em obter garantias trabalhistas essenciais.

Dentre essas distorções, as mais flagrantes são as leis especiais que concediam aos jornalistas profissionais descontos (e em alguns casos a gratuidade) em transportes públicos e a isenção fiscal (prevista na Constituição Federal de 1946)

${ }^{26}$ A campanha "O petróleo é nosso", realizada entre 1947 e 1953 por grupos nacionalistas, tinha por objetivo pressionar o Congresso Nacional para que fosse aprovada a lei que estabelecia o monopólio estatal na exploração de petróleo no Brasil e criava a Petrobrás. Depois de uma longa mobilização popular que envolveu praticamente toda a imprensa da época, a lei foi aprovada em outubro de 1953.

${ }^{27}$ O documento enviado ao Congresso, que pedia a cassação do então Presidente da República, foi assinado, em primeiro lugar, pelo presidente da ABI, jornalista Barbosa Lima Sobrinho 
que os excluía do pagamento do imposto de renda e de outros tributos, como impostos prediais e de transmissão de bens.

A legislação garantia, ainda, aos jornalistas, o direito de pagar $50 \%$ do valor dos ingressos em casas de diversões e de passagens aéreas. Além de todas essas vantagens, aos jornalistas era garantido o direito à aposentadoria especial após 30 anos de serviço.

Esses privilégios usufruídos pelos jornalistas, diga-se de passagem, sem grandes crises de consciência, demonstram claramente a importância que a ABI assume junto às instâncias que controlam o poder, constituindo-se numa instituição de alcance nacional e de relevante importância no cenário político.

Apesar dessas distorções e das benesses obtidas por meio de uma ação eminentemente política, a presença permanente, nos últimos cem anos, como figura mediadora e fiscalizadora da ação do Estado e seus entes sobre a vida do cidadão comum reserva à $A B I$ um papel destacado entre as instituições que participam dos processos de socialização e de mobilização política no país.

Essa trajetória acabou repercutindo positivamente na maneira como a sociedade atribui valor à atividade dos profissionais de imprensa, garantindo-lhes o reconhecimento de sua importância social: “(...) a $A B I$ atuou como instituição simbolicamente estimuladora da profissionalização e da valorização da profissão de jornalista no País" (LENE, 2013:25).

A Associação Brasileira de Imprensa reúne 8.300 associados $^{28}$, num universo de aproximadamente 145 mil profissionais registrados ${ }^{29}$. Além de representar os jornalistas filiados e de promover atividades políticas e culturais, a ABI oferece aos seus sócios e dependentes serviços de assistência médica e de assistência jurídica.

${ }^{28}$ Dados de 2013, obtidos junto ao site oficial da instituição: www.abi.org.br, acessado em 10/04/2015

${ }^{29}$ O número de jornalistas com registro profissional no Brasil mais que dobrou na primeira década de 2000 , em relação aos 20 anos anteriores, e alcançou 145 mil em dezembro de 2011 . A estimativa é do projeto de pesquisa "Perfil profissional do jornalismo brasileiro", realizado pela UFSC em parceria com a FENAJ, que teve acesso a duas relações de registrados, fornecidas pelo Ministério do Trabalho e Emprego (MTE), com 92 mil nomes ao todo. Fonte: http://perfildojornalista.ufsc.br/2012/08/29/brasil-tem-145-mil-jornalistas-registrados/ , acessado em 18/03/2015 
Apesar de sua dimensão histórica e de sua importância na formação e consolidação de uma identidade profissional de nossos jornalistas, é nítido que a $\mathrm{ABI}$ vem perdendo espaço, ao longo dos últimos anos, no cenário político brasileiro.

Sua capacidade de propor temas a serem discutidos e de levantar questões de interesse geral da sociedade tem se reduzido consideravelmente, o que fica demonstrado a partir da constatação de que a Associação já não se faz presente, há algum tempo ${ }^{30}$, em episódios relevantes de manifestação e mobilização social.

\subsubsection{O Sindicalismo Entre Os "Proletários Intelectuais"}

A formação das elites brasileiras, do período colonial até as primeiras décadas do século XX, teve como traço marcante certa identidade ideológica, cuja origem pode ser atribuída ao predomínio absoluto de Coimbra como principal centro formador, o que levou à constituição de um "núcleo homogêneo de conhecimentos e habilidades, em consequência de sua [das elites] educação superior se concentrar na formação jurídica" (GONÇALVES, 2011:1).

Como parte da elite de juristas, os primeiros jornalistas brasileiros se enquadram, quase que sem exceção, nesse perfil: são bachareis inseridos num ambiente intelectual construído a partir das tradições mercantilistas e absolutistas portuguesas. O que faz com que se comportem de maneira muito parecida, mesmo quando divergem politicamente. Afinal, esses intelectuais formavam uma "ilha de letrados num mar de analfabetos" (CARVALHO apud GONÇALVES, 2011).

Essa condição comum aos nossos primeiros jornalistas irá, de certa forma, influenciar a construção identitária daqueles que viriam a constituir os quadros iniciais de nossas redações. Ao se considerarem, majoritariamente, "intelectuais", os jornalistas brasileiros simplesmente mantêm uma percepção que herdaram ao longo da história e que acabou por chegar até os nossos dias.

Essa percepção de que fazem parte de um grupo diferenciado de trabalhadores (alguns se julgam, além de intelectuais, profissionais liberais apesar

30 A última participação importante da $A B I$ em episódios de impacto social e político foi no processo de impeachment do presidente Fernando Collor, em 1992 
de serem empregados em empresas de comunicação) pode explicar a baixa adesão que os profissionais da imprensa sempre tiveram em relação à atividade sindical ou a qualquer outra ação associativa.

É fato que os jornalistas já possuem associações prestigiadas no contexto da federação, mas o nível de participação é tão frustrante como no final do século XIX. Se é verdade que nos períodos de repressão jornalistas e empresários da comunicação se unem nas mesmas trincheiras em defesa das liberdades de imprensa e de expressão, também é real que na democracia formal tem-se o mesmo conflito de classe registrado há um século e meio (PEREIRA, 2008:35).

Uma pesquisa realizada em 2012 pela Universidade Federal de Santa Catarina, em parceria com a Federação Nacional dos Jornalistas ${ }^{31}$, e que tinha como objetivo definir o perfil do jornalista brasileiro apontou, claramente, a tendência que esses profissionais têm de não se envolver em atividades classistas, o que sem dúvida alguma repercute na capacidade de mobilização e de representatividade dessas associações.

Mais da metade dos jornalistas entrevistados na pesquisa se consideram de esquerda, ao mesmo tempo em que cerca de um terço declaram não ter nenhuma afinidade ideológica com partidos ou correntes políticas.

Noventa por cento dos jornalistas que responderam a pesquisa disseram não ser filiados a partidos políticos e quarenta e cinco por cento deles jamais participaram de movimentos sociais, associações ou organizações.

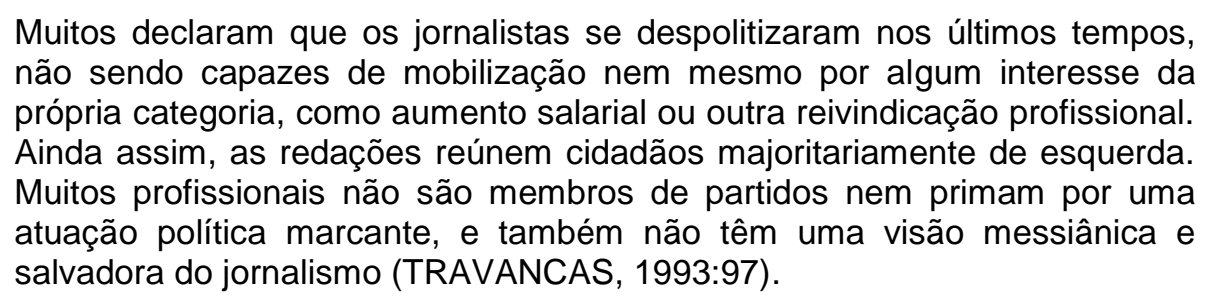

Diante desses dados, fica claro que não faz parte do processo de construção da identidade profissional dos jornalistas o engajamento sindical ou a participação em atividades associativas.

31 Bergamo, Alexandre; Mick, Jacques (Coord); e Lima, Samuel. Perfil do Jornalista Brasileiro. Características demográficas, políticas e do trabalho. Síntese dos principais resultados. UFSC - FENAJ, 2012 
O que poderia vir a ser encarado como algo paradoxal, já que o jornalismo é elemento fundamental nos processos históricos de mobilização e participação política das diversas categorias de trabalhadores, é na verdade resultado de uma opção consciente, baseada numa visão identitária que coloca o jornalista como um intelectual, distante, portanto, da realidade plena de dificuldades e de lutas que compõem o universo das demais categorias profissionais (inclusive a dos trabalhadores nas empresas jornalísticas).

Entretanto, há mudanças significativas no perfil dos jornalistas contemporâneos que têm sido estudadas e avaliadas visando entender de que maneira esses profissionais se percebem num ambiente cada vez mais dominado pela tecnologia, por novas formas e modelos de comunicação e caracterizado por relações empregatícias precárias.

Hoje, o jornalista prefere ser visto como profissional e pragmático, ao invés do personagem romântico e boêmio construído pela literatura e pelo cinema. Essa mudança na direção da profissionalização está relacionada, segundo Alzira Alves de Abreu, à ampliação das demandas do mercado, ao crescimento dos meios de comunicação de massa e à implantação da grande indústria cultural.

\footnotetext{
É nesse momento que aparecem as lógicas da diferenciação social, quando os membros do grupo que atuavam visando à organização do espaço do trabalho buscam limitar a concorrência através do estabelecimento de fronteiras, regularizando a profissão. A ela só terão acesso agora aqueles que possuírem uma formação especializada, obtida nas faculdades de jornalismo ou de comunicação (ABREU, 1998:8).
}

Nesse sentido, a oferta dos cursos superiores de formação de profissionais do jornalismo irá completar, no nosso ponto de vista, as condições que permitirão a construção de uma identidade comum, contribuindo decisivamente para o reconhecimento social dos jornalistas brasileiros, como veremos a seguir.

\subsubsection{A implantação dos cursos superiores de Jornalismo no Brasil}

Em maio de 1904, o magnata da imprensa norte-americana Joseph Pulitzer indaga num artigo se "existe alguma atividade para a qual o homem não necessite ser treinado - treinado em casa, treinado em escolas, treinado em faculdades, treinado por mestres-artesãos, ou treinado por meio de uma amarga experiência - 
por meio das chamas que fazem com que a criança tenha medo do fogo?" ${ }^{32}$ (PULITZER, 1904:642).

O objetivo de Pulitzer era contestar as críticas que havia recebido ao propor à Universidade de Colúmbia a criação de um curso específico para o ensino do Jornalismo, críticas que, segundo ele, demonstravam preconceito e ignorância dos que consideraram a ideia como o delírio de um visionário.

Segundo Marques de Melo (2004:76), as críticas à proposta de Pulitzer partiam, principalmente, do seio da corporação profissional, dos jornalistas que sem preparo prévio para o exercício da atividade, demonstravam um "afetado desprezo" pela educação formal.

Defendendo a tese da inutilidade das escolas de jornalismo, Frederic Hudson, diretor do The York Herald sentenciava: "o único lugar onde alguém pode aprender jornalismo é a redação de um grande jornal". Contudo, o discurso representativo dessa corrente foi explicitado pelo escritor John Dillon: "Nós, jornalistas, estamos firmemente convencidos de sermos como os poetas: born not made" (RIZZINI apud MELO, 2004:76).

Pulitzer insistia que uma escola para formar jornalistas deveria "exaltar os princípios, o conhecimento e a cultura", fazendo da alma do jornalista a alma do jornal, construindo ideais, porém sem se esquecer de manter a contabilidade em dia (Ibidem:77).

Toda essa controvérsia serviu de pano de fundo para o surgimento das primeiras escolas de ensino regular do Jornalismo nos Estados Unidos, nas décadas iniciais do século $X X^{33}$. Foram adotados dois modelos: o primeiro, em 1908, na Universidade do Missouri, instituiu um curso de graduação destinado a formar editores e repórteres. O curso incluía a participação dos alunos num jornallaboratório.

Já o segundo modelo, implantado em 1912 pela Universidade de Colúmbia a partir da doação feita por Pulitzer de dois milhões de dólares, consistia num curso de

32 Tradução feita pelo autor a partir do texto original, encontrado no seguinte endereço eletrônico: https://archive.org/stream/jstor-25119561/25119561\#page/n39/mode/2up, acessado em 13/03/2015

33 Há registro da criação de um curso de formação jornalística, em 1869, no Washington College, estimulado pelo general Robert E. Lee, cujo objetivo era, essencialmente, a formação e o aperfeiçoamento de tipógrafos. (MELO, 2004:75) 
pós-graduação, destinado a graduados de outras áreas (principalmente dos cursos ligados à literatura).

Mas o primeiro registro acadêmico que tem o jornalismo como objeto data do século XVII, quando o erudito alemão Tobias Peucer defendeu, em 1690, na Universidade de Leipzig, uma tese de doutorado que tratava das "relações e relatos de novidades". Peucer, que havia estudado teologia e medicina, compreendeu a importância que a ainda incipiente atividade jornalística adquiria num mundo em rápida mutação com a Reforma Protestante, a ascensão da burguesia comercial e as mudanças nos processos de relacionamento interpessoal e na política.

\begin{abstract}
A leitura do trabalho, quatro séculos depois, é surpreendente. Parece escrito no século XXI. Questões como a ética profissional, os critérios de noticiabilidade, a mercantilização da informação e a exploração sensacionalista dos fatos já eram abordadas por Peucer. (...) Há considerações até sobre os famosos "seis W's" e o "lead", que tem sido considerado como uma invenção norte-americana. O pesquisador alemão sugeriu que a origem dessa técnica de abertura do texto jornalístico pode ser encontrada na retórica cultivada nos discursos da Antiguidade Clássica (ADGHIRNI, 2006:52).
\end{abstract}

$\mathrm{Na}$ Europa, os primeiros registros sobre o ensino regular do jornalismo indicam como referência a Universidade de Breslau, na Alemanha, onde em 1806 já era oferecida uma disciplina cujo objetivo seria o de preencher a demanda pela formação específica de novos profissionais, tendo em vista que a industrialização do jornalismo gerou a necessidade de aparição de um profissional com um novo perfil (SOUSA, 2009, passim).

Ainda no início do século XIX, outras experiências bem sucedidas de implantação de cursos superiores de jornalismo ocorrem na França, na Suíça e na Alemanha. Já quase no final do século, em 1899, o jornal Le Figaro apoiou a iniciativa do jornalista francês Albert Batailer de fundar uma Escola Superior de Jornalismo, em Paris.

Um ano antes (1898), reunidos em Lisboa no primeiro congresso mundial de Jornalismo, os nomes mais importantes da profissão à época pregam a importância do ensino específico na formação dos profissionais da área e atribuem às novidades tecnológicas a necessidade de novos conhecimentos e de nova postura diante da profissão. 
Com o aperfeiçoamento das máquinas de imprimir, com o telégrafo e o telefone, com a transformação do espírito público, cada vez mais ávido de ser informado, uma metamorfose se operou no jornalismo: a polêmica foi relegada ao segundo plano e a informação passou para primeiro. No dia em que essa transformação se verificou, o jornalismo converteu-se numa carreira; (...) para chegar ao recrutamento regular, à renovação normal da imprensa, é preciso organizar os quadros de reserva e tornar menos penosos os anos de aprendizagem aos jovens que se sintam com vocação; e para isso é necessário que a educação geral se complete com a educação profissional (MELO, 2007:10).

Em relação à América Latina, as iniciativas preliminares para o ensino regular do jornalismo se dão na Argentina e no Brasil, países onde na década de 1930 já se estabelecem cursos para a capacitação de profissionais da imprensa tendo como modelo 0 viés norte-americano de formação profissional, com ênfase no desenvolvimento de habilidades e competências técnicas.

No caso específico do Brasil, a discussão sobre a implantação de cursos de ensino superior voltados à formação de jornalistas já se fazia presente nos debates e conversas que antecederam à criação da Associação Brasileira de Imprensa (ABI). Seus fundadores já defendiam a importância de uma sólida formação específica para os profissionais que atuavam nessa atividade.

Essa seria condição essencial, segundo aqueles que buscavam institucionalizar o trabalho jornalístico, para estabelecer um campo profissional legítimo, no qual todos os envolvidos tivessem reconhecidos seus méritos e sua importância, eliminando os preconceitos e a desigualdade entre repórteres e redatores, principalmente, por serem estes últimos oriundos, em sua esmagadora maioria, dos cursos de formação de bachareis em Direito.

A hegemonia desses "bachareis" no exercício de funções redacionais os
transforma numa espécie de casta dentro das nascentes empresas
jornalísticas. Cria-se um antagonismo latente entre os "redatores" e os
"repórteres", figurando estes últimos como segmento subalterno, recrutado
nas camadas médias da sociedade, mas carentes de formação superior
(MELO, 2004:79).

Durante o Primeiro Congresso de Jornalistas, promovido em 1918, pela ABI, foi discutida a criação de uma Escola de Jornalismo, cujo objetivo, segundo seus idealizadores, não seria o de formar doutores nem bachareis, mas ensinar matérias específicas, ligadas ao campo profissional. Para isso, seriam utilizadas como referência teórica disciplinas ligadas às ciências humanas e desenvolvidas habilidades práticas por meio do ensino de conteúdos eminentemente técnicos. 
Além disso, o currículo do curso previa a criação de um jornal-laboratório, no qual os alunos pudessem desenvolver suas competências em relação ao uso da linguagem e das técnicas aprendidas em sala de aula, produzindo matérias e fazendo reportagens.

[Reportagens] que poderiam ser mundanas, artísticas, policiais ou sociais, escrevendo artigos de política e finanças, com orientação própria ou ditada pelo professor, fazendo crítica de música, pintura, teatro e letras, conforme o adiantamento do curso regular da Escola (SÁ apud MELO, 2004:81).

Ao propor a Escola de Jornalismo, a ABI tinha como referência o ensino do jornalismo nos Estados Unidos, país que já dispunha, àquela altura, de cursos regulares nas Universidades do Missouri e do Arizona, além do curso de pósgraduação ofertado pela Universidade de Colúmbia.

Mas a ideia teria de esperar até 1935, ano em que o educador Anísio Teixeira, responsável pela criação da Universidade do Distrito Federal, inclui o curso de jornalismo entre os diversos e inovadores cursos que compunham a lista de ofertas da nova instituição de ensino, como administração, diplomacia, serviço social, biblioteconomia, paisagismo, cinema e publicidade.

Teixeira confiou ao jornalista Pedro Costa Rego, então editor-chefe do Correio da Manhã, a tarefa de planejar e implantar o curso, recomendando que o modelo a ser seguido valorizasse a formação humanística, a exemplo do que acontecia nos cursos europeus, em detrimento de aspectos técnicos, como enfatizavam as escolas norte-americanas (LENE, 2013:27).

Por divergências políticas com o Estado Novo de Vargas, a experiência da Universidade do Distrito Federal foi interrompida em 1939 e o curso deixou de ser oferecido.

A partir daí, a $A B I$ buscou sensibilizar o governo para a importância da existência de uma Escola de Jornalismo. Nesse sentido, tratou de vincular a ideia da criação da escola ao processo de regulamentação da profissão, o que efetivamente ocorreu com a publicação do Decreto-Lei no 910, de 30 de novembro de $1938^{34}$, que definia as relações trabalhistas entre os profissionais da imprensa e as empresas 
jornalísticas, além de criar as escolas de jornalismo e estabelecer a exigência de diploma para o exercício da profissão.

Apesar de previstas na legislação criada pelo Estado Novo, as escolas não saíram do papel, pois conforme estabelecia a Lei, a iniciativa deveria caber aos Estados, que não se interessaram em promover os cursos.

Em 1943, Vargas faz nova investida e cria pelo Decreto-Lei 5.480, de 13 de maio de $1943^{35}$, o curso superior de jornalismo da Faculdade Nacional de Filosofia e Letras. A lei previa que o curso seria realizado com a colaboração da "Associação Brasileira de Imprensa, dos sindicatos representativos das categorias de empregados e empregadores das empresas jornalísticas". Novamente, questões políticas e econômicas impediram o funcionamento do curso.

Com isso, o primeiro curso regular de ensino superior de Jornalismo no Brasil só começaria a funcionar em $1947^{36}$, numa iniciativa da Fundação Cásper Líbero ${ }^{37}$ e vinculado à Faculdade de Filosofia, Ciências e Letras da Pontifícia Universidade Católica (PUC) de São Paulo.

Em 1948, no Rio de Janeiro, é finalmente criado o primeiro curso de Jornalismo vinculado a uma instituição pública: a Faculdade Nacional de Filosofia da Universidade do Brasil (hoje, Universidade Federal do Rio de Janeiro). Os professores do curso foram inicialmente indicados pela $A B I$ e pagos com recursos da Companhia de Cigarros Souza Cruz. Dentre eles, destacavam-se os nomes de Danton Jobim, Celso Cunha, Josué de Castro, Celso Kelly, Fernando Tude de Souza e Marciel Dias Pequeno (LENE, 2013:27).

${ }^{35}$ Anexo 2

${ }^{36}$ Autorizado pelo Decreto no 23.087, de 19 de maio de 1947

${ }^{37}$ Cásper Líbero - Advogado e empresário paulista. Nasceu na cidade de Bragança Paulista (SP), no dia 2 de março de 1889. Dedicou-se ao jornalismo e construiu um sólido patrimônio por meio de suas empresas jornalísticas, como o jornal diário "A Gazeta", adquirido por ele em 1918 e que daria origem a outras empresas, como "A Gazeta Esportiva" e a "Rádio Gazeta".

Líbero morreu em 1943, num acidente de avião no Rio de Janeiro e deixou expresso em seu testamento o desejo de que fosse constituída uma fundação com o objetivo de garantir a manutenção de suas empresas e de estimular o ensino do jornalismo.

Em 1947, a Fundação Cásper Líbero oferece o primeiro curso regular de ensino do jornalismo na América Latina. 
A partir daí, o ensino regular de Jornalismo se espalha por todo o país, especialmente pelas regiões Sudeste e Sul até que, no início da década de 1980, os principais jornais do eixo Rio-São Paulo estabelecem critérios específicos de contratação e estágio tendo como alvo os estudantes dos cursos então oferecidos.

De acordo com dados estatísticos do Ministério da Educação - MEC existem atualmente no Brasil 368 cursos de Jornalismo ${ }^{38}$. Em 2009, uma decisão do Supremo Tribunal Federal (STF) revogou a Lei que dispunha sobre o exercício da profissão de jornalista ${ }^{39}$, em vigor desde o governo militar. Os Ministros do STF analisaram um recurso extraordinário interposto pelo Sindicato das Empresas de Rádio e Televisão no Estado de São Paulo e pelo Ministério Público Federal.

No recurso, o Ministério Público alegava que a legislação que então regulava o exercício da profissão, o que incluía a obrigatoriedade do diploma, era incompatível com a Constituição de 1988, pois cerceava a liberdade de expressão.

Ainda em 2009, atendendo à pressão das entidades representativas da categoria, notadamente a Federação Nacional dos Jornalistas (FENAJ), foram apresentados no Congresso Nacional Projetos de Emenda Constitucional (PEC) $)^{40}$ que reestabelecem a obrigatoriedade do diploma para o exercício da profissão de jornalista no Brasil. O assunto ainda está em discussão e tem dividido as opiniões de parlamentares e autoridades.

Independentemente do que vier a ocorrer em relação ao diploma, o certo é que a existência e a manutenção de cursos superiores especificamente voltados à formação de profissionais para a atividade jornalística constituiu-se, historicamente, num dos elementos fundamentais para que a profissão obtivesse, por parte da sociedade, o reconhecimento de sua importância na mediação, na fiscalização e na indução de mudanças essenciais para a sociedade brasileira nos últimos dois séculos.

${ }^{38}$ Fonte: Censo do Ensino Superior - e-MEC (www.mec.gov.br), acessado em 18/03/2015

${ }^{39}$ Decreto-Lei no 972, de 17 de outubro de 1969

${ }^{40}$ Foram apresentadas as PEC № 386/09 e a PEC 206/12 reestabelecendo a obrigatoriedade do diploma para o exercício da profissão de jornalista 


\subsection{AS ONDAS DO RÁDIO DEMOCRATIZAM A INFORMAÇÃO E AMPLIAM O ALCANCE DO JORNALISMO}

Às mudanças no jornalismo impresso acrescentaram-se, ainda na primeira metade do século $X X$, o surgimento e a consolidação de um novo veículo de comunicação, capaz de mobilizar a opinião pública como nunca antes ocorrera. Um veículo que passaria a fazer parte da realidade e a povoar o imaginário popular e que se tornaria fundamental para as pessoas que passaram a viver cada vez mais concentradas nas grandes cidades, carentes de informação e de entretenimento.

Muito mais que um novo veículo de comunicação, um dispositivo eletrônico capaz de levar a voz humana a longas distâncias, o rádio provoca uma considerável mudança na forma como as notícias são construídas e inaugura uma nova era e um novo modelo de comunicação: a comunicação eletrônica.

Os princípios teóricos sobre a propagação de ondas eletromagnéticas já eram bastante conhecidos desde o século XIX. Mas foi no início do século seguinte que esses conhecimentos permitiram a transmissão de sinais eletrônicos a distância, abrindo caminho para o desenvolvimento do rádio. As primeiras transmissões comerciais ocorridas por volta de 1919, nos Estados Unidos, já incluíam a divulgação de notícias e informações de interesse público.

No Brasil, o rádio chega, oficialmente, em 1922, durante as comemorações do centenário da independência, por iniciativa da empresa norte-americana Western Electric Company, que trouxe para o evento no Rio de Janeiro um transmissor de 500 watts e alguns receptores que, espalhados pelos recintos e pavilhões que compunham a festa, transmitiram música e discursos de autoridades.

Visto inicialmente como uma espécie de curiosidade científica, o rádio chama a atenção de membros da Academia Brasileira de Ciências, principalmente do médico Edgar Roquette-Pinto e do engenheiro Henrique Morize, que no ano seguinte (20 de abril de 1923) põem no ar a Rádio Sociedade do Rio de Janeiro, dando início ao processo de implantação da radiodifusão no Brasil. 
O potencial informativo do rádio não passou despercebido a Roquette-Pinto que logo começa a transmitir, regularmente, notícias, informações e comentários políticos, no que viria a ser o primeiro jornal radiofônico brasileiro.

O Jornal da Manhã não era um simples noticioso, nem um modesto relato dos acontecimentos. Era o fato comentado, esmiuçado e interpretado com a autoridade do sábio. O Jornal da Manhã, da Rádio Sociedade do Rio de Janeiro, foi iniciativa jamais igualada. Por meio dele, o comentarista apreciava os acontecimentos nos noticiários dos jornais, lendo-lhes as manchetes e oferecendo um panorama inigualável de concisão, de realidade e de objetividade (LOPES apud ORTRIWANO, 2002:69).

A instabilidade política experimentada pelo Brasil na década de 1920 induz o governo de Arthur Bernardes a tentar impedir a transmissão de informação política no rádio. O Decreto $\mathrm{n}^{-}$16.657, de 5 de novembro de 1924, que "aprova 0 regulamento dos serviços de radiotelegraphia e radiotelephonia, no território brasileiro", estabelecia que as sociedades civis envolvidas com a radiodifusão só poderiam transmitir programas com objetivos educativos, "ficando expressamente proibida a propagação de notícias internas de caráter político sem a prévia permissão do governo" (CALEBRE, 2004:16).

Foram tempos políticos difíceis, em que se originaram diversos movimentos de contestação ao governo central, como os que se seguiram ao episódio conhecido como "os dezoito do forte", em 1922. A agitação, promovida por militares de baixa patente, vai levar ao surgimento do "tenentismo" e a acontecimentos violentos, como a "revolta gaúcha" de 1923 e a "revolta paulista", em 1924, culminando com a "Coluna Prestes", em 1926, o que explica a preocupação do governo com o uso do rádio como arma política.

E o que era apenas um temor do governo se torna realidade durante a Revolução Constitucionalista de 1932, em São Paulo, quando as emissoras paulistas e cariocas - principalmente a Rádio Record (paulista) e a Rádio Phillips (do Rio de Janeiro) - tornaram-se instrumentos importantes no processo de mobilização ideológica, travando verdadeiras batalhas de informação e contrainformação.

Tanto as transmissões cariocas captadas em São Paulo quanto as mensagens paulistas captadas no Rio de Janeiro passaram a ser consideradas perigosas. As emissoras empenhavam-se em desmentir as informações dadas pelo "inimigo". (...) o rádio era em si mesmo um veículo revolucionário, com seu largo alcance e rapidez na divulgação dos fatos (CALEBRE, 2004:18). 
Ao perceber o valor do rádio como instrumento de mobilização popular, Getúlio Vargas se apressa a regulamentar o seu funcionamento, tanto no aspecto técnico (definindo regras que irão regular o uso do espectro eletromagnético e a distribuição das frequências) quanto no que diz respeito às atividades profissionais que surgem com o novo veículo.

Ao mesmo tempo em que buscou estabelecer mecanismos de controle e de regulação da atividade radiofônica, a legislação criada por Vargas iria estimular o seu crescimento ao liberar o uso de mensagens comerciais $^{41}$, o que contribuiu para o surgimento de novas emissoras e financiou o crescimento do setor dando início ao que ficaria conhecido no Brasil como a "Era do Rádio".

Mas a relação de Vargas com o rádio também teria episódios de retrocesso democrático, como a instauração da censura durante o período do "Estado Novo" e a criação do DIP (Departamento de Imprensa e Propaganda), órgão responsável pela política de promoção do governo e do seu líder.

Em 1935, Vargas reage violentamente à tentativa de golpe promovida pelo Partido Comunista, movimento que ficou conhecido como a "Intentona Comunista", decretando o estado de emergência, com base na então recém-criada Lei de Segurança Nacional, e dá início ao processo de instalação do "Estado Novo", na verdade um golpe de estado que implanta no país uma ditadura que irá perdurar até 1945.

É justamente durante a vigência do Estado Novo que os mecanismos de controle e censura do governo irão se aperfeiçoar. A Constituição outorgada por Vargas, em 1937, prevê a criação do $\operatorname{DIP}^{42}$ e o rígido controle sobre as atividades artísticas, culturais e jornalísticas no país, incluindo as transmissões radiofônicas.

No que se aplicava às atividades radiofônicas, a legislação instituída pelo governo Vargas definia, inclusive, a duração dos intervalos comerciais:

\footnotetext{
${ }^{41}$ Decreto no 21.111, de 1을 de março de 1932 - Anexo 3

42 Decreto-Lei no 1949, de 30 de dezembro de 1939 - Dispõe sobre o exercício da atividade de imprensa e propaganda no território nacional.
} 
Art. 94. Durante a execução dos programas de radiodifusão é permitida a propaganda comercial, por meio de dissertações proferidas de maneira concisa, clara e conveniente à apreciação dos ouvintes, observadas as seguintes condições:

a) o tempo destinado ao conjunto dessas dissertações não poderá ser superior a $20 \%$ do tempo total de irradiação de cada programa;

b) cada dissertação durará, no máximo, 60 segundos, podendo, nos dias úteis, entre 7 e 16 horas, esse máximo ser elevado a 75 segundos;

c) as dissertações deverão ser intercaladas nos programas, de sorte a não se sucederem imediatamente;

d) não será permitida, na execução dessas dissertações, a reiteração de palavras ou conceitos.

$\S 1^{\circ}$ - Fica proibida a irradiação de trechos musicais cantados em linguagem imprópria à boa educação do povo, anedotas ou palavras nas mesmas condições.

$\S 2^{\circ}$ - Os estabelecimentos comerciais que possuírem aparelhos de radiodifusão ficam obrigados a transmitir o programa oficial da D.I.P. ${ }^{43}$

Assim, Vargas, por meio de um Decreto-Lei, criava um espaço exclusivo de propaganda política de seu regime, ao mesmo tempo em que impedia outros segmentos de divulgarem suas mensagens. O rádio assume, portanto, papel decisivo na construção de um discurso político forte, que irá sustentar, durante um período de tempo considerável, o governo de força implantado pelo Estado-Novo.

Além de ampliar o acesso à informação, o jornalismo radiofônico promoveu importantes alterações no modo de construção da notícia, com a reportagem e a informação ganhando cada vez mais espaço em detrimento da opinião. Na voz empostada de locutores e apresentadores, a notícia adquire credibilidade e espaço até então desconhecidos no Brasil.

A partir da década de 1940, o radiojornalismo (por meio dos chamados "jornais falados") assume a condição de principal meio de informação do País. Os noticiários passam a ocupar um espaço nobre na programação das emissoras e a desempenhar um papel fundamental na construção social de uma nova realidade que tem como referência principal a narrativa jornalística. Se não "deu" no rádio é porque não aconteceu!

${ }^{43}$ O programa a que se refere este parágrafo era a "Hora do Brasil", criado em 1935 pelo DIP e transmitido em rede nacional de rádio, todos os dias úteis, das $19 \mathrm{~h}$ às $20 \mathrm{~h}$. Esse programa é atualmente transmitido com o nome de "A Voz do Brasil", num formato um pouco modificado. Ele é produzido pela EBC e pelas assessorias de Comunicação do Senado, da Câmara e do Supremo Tribunal Federal. 
O jornalismo esteve presente no rádio desde as primeiras experiências de exploração da radiodifusão. As emissoras, de maneira geral, são inauguradas transmitindo algum evento ou, ao menos, informando sobre sua própria existência. Primeiro meio de comunicação eletrônico, operando na velocidade do som, o rádio já nasceu glocal, termo cunhado recentemente em função das tecnologias hoje disponíveis: tanto contava os fatos do mundo como os da casa do vizinho (ORTRIWANO, 2002:67).

Antes do rádio, o domínio da leitura era elemento indispensável para a inserção do indivíduo no universo da notícia. Era preciso saber ler para decifrar o que os jornais destacavam, condição que mantinha mais da metade da população brasileira distante de informações essenciais.

O rádio ampliou o alcance do jornalismo, incluindo no debate político milhões de brasileiros, até então segregados, pelo analfabetismo e/ou pela falta de recursos, do consumo regular de notícias. A população passa a acompanhar "os fatos conforme eles iam ocorrendo, de forma a se tornar participante do episódio em si." (...) "O rádio coloca o ouvinte dentro da história” (BAUM, 2004:20).

O rádio acabou por fortalecer o papel do jornalismo na construção de uma consciência coletiva, reproduzindo no Brasil o que já ocorria em outros países, nos quais assumira importante papel na mobilização social e política, na divulgação de valores culturais e na implantação de empreendimentos comunicacionais mais lucrativos e eficientes, graças ao aumento e à diversificação de suas fontes de receita publicitária.

O novo meio de comunicação revolucionou a relação cotidiana do indivíduo
com a notícia, imprimindo uma nova velocidade e significação aos
acontecimentos. Ao partilharem das mesmas fontes de notícias, os
indivíduos se sentiam mais integrados, possuíam um repertório de questões
comuns a serem discutidas (CALABRE, 2004:9).

Considerando todo este impacto provocado pelo rádio, nos parece evidente que as empresas jornalísticas que investiram na radiodifusão tiveram aumentadas as suas chances de sucesso econômico, graças à capacidade do rádio em se aproximar da população, ganhando sua confiança e desfrutando de uma credibilidade até então desconhecida dos jornais impressos, ampliando sua importância graças ao aumento do interesse da população pela notícia.

Esse aumento de credibilidade e de eficiência foi essencial para que 0 jornalismo ampliasse sua capacidade de gerar lucro e, com isso, criasse as 
condições necessárias ao surgimento dos grandes grupos empresariais de comunicação no Brasil.

No nosso caso específico, tanto os Diários Associados quanto o Grupo Globo irão marcar o início de suas trajetórias como grandes conglomerados midiáticos ao investir na radiodifusão ${ }^{44}$, atingindo os mais distantes lugares no Brasil, libertando-se não só das limitações impostas pela falta da educação formal, como também da enorme dificuldade representada pela imensidão do nosso território, pois as ondas do rádio chegavam onde quer que houvesse gente interessada em informação e entretenimento.

Não podemos desestimar a obra de propaganda e de cultura realizada pelo rádio e, principalmente, a sua ação extra-escolar; basta dizer que o rádio chega até onde não chegam a escola e a imprensa, isto é, aos pontos mais longínquos do país e, até, à compreensão do analfabeto (LOURIVAL FONTES apud SAROLDI; MOREIRA, 2005:27).

A capacidade do rádio de atrair a atenção e mobilizar as pessoas chamou a atenção das instituições, do mercado, dos políticos e, principalmente, do governo. 0 uso político do rádio no Brasil foi consequência natural desse fascínio que o novo meio causava e que já o consagrara como principal elemento de propaganda política em várias partes do mundo.

O aperfeiçoamento técnico do rádio coincide com grandes transformações no ambiente político em vários países, tanto da Europa quanto nas Américas. A partir da década de 1930 o rádio desempenhou papel fundamental nas estratégias de propaganda dos mais diferentes regimes políticos, em diferentes lugares do mundo.

Foi assim nos países de regimes nacionalistas fortes, de viés totalitário, como na Alemanha de Hitler, na Itália de Mussolini, na Espanha de Franco e, também, no Brasil de Vargas.

Mesmo em países de grande tradição democrática, como nos Estados Unidos e na Inglaterra, o rádio iria desempenhar um papel fundamental no processo de mobilização política da sociedade, com Roosevelt, nos Estados Unidos, durante os

\footnotetext{
${ }^{44}$ Em 1935, Assis Chateaubriand funda a Rádio Tupi, no Rio de Janeiro, primeira emissora do que viria a ser a sua extensa rede de "Emissoras Associadas". E em 1944, Roberto Marinho inaugura a Rádio Globo, também no Rio de Janeiro.
} 
anos da grande depressão, e com Churchill, na resistência ao nazismo durante a Segunda Guerra Mundial.

E é justamente esse grande conflito mundial que irá impulsionar o radiojornalismo no Brasil. $O$ constante interesse da população pelo que ocorria na Europa e nas mais diversas frentes de combate fez com que a procura por aparelhos de rádio aumentasse de forma exponencial.

As pessoas permaneciam a maior parte do tempo com os aparelhos ligados, acompanhando os noticiários que se sucediam ao longo do dia.

A Segunda Guerra Mundial faz do rádio o seu instrumento. As notícias sucedem-se a cada minuto, multiplicam-se os sistemas informativos, a audiência exige cada vez mais e mais notícias dos diferentes fronts (CAMARGO apud ORTRIWANO, 2003:72).

A regularidade com que eram levados ao ar os informativos, aliada à linguagem direta, simples e emotiva das notícias, respondem pelo sucesso desse novo meio de comunicação. Repórteres e redatores aprendem a lidar com as especificidades da notícia radiofônica e garantem o sucesso dos programas, atraindo um número cada vez maior de anunciantes, aumentando a receita dessas empresas e de seus conglomerados.

Um dos exemplos mais significativos das mudanças que o rádio introduz no jornalismo está no sucesso alcançado por um programa jornalístico que foi ao ar, pela primeira vez, em 28 de agosto de 1941. O formato do Repórter Esso inova ao trazer para o noticiário radiofônico uma linguagem mais curta, dinâmica, dramática, privilegiando as notícias da guerra que se espalhara pelo mundo e que logo chegaria ao Brasil.

Com um noticiário sucinto, vibrante, de cinco minutos exatos de duração. [...] Isso foi bastante para clarear a mentalidade radiodifusora para o velho ângulo da divulgação. Transmitido em horários rigorosamente respeitados, anunciado pela vinheta musical que se tornou inconfundível, adquiriu estatura e autenticidade para ser conhecido e admirado pelo Brasil inteiro (LOPES apud ORTRIWANO, 2003:73).

Depois de trinta anos como o mais importante veículo de transmissão de informação e de divulgação artístico-cultural, contribuindo, decisivamente, para a construção dos primeiros grandes conglomerados midiáticos brasileiros, o rádio 
perde espaço para um novo veículo que vai somar ao seu imediatismo e alcance a força da imagem.

A partir da segunda metade da década de 1950, a televisão conquista grande parte do público que até então encontrara no rádio seu principal meio de informação. Os noticiários radiofônicos serviram de modelo para os primeiros telejornais, que mantiveram, durante algum tempo, características muito próximas ao radiojornalismo, principalmente ao utilizar uma linguagem vibrante e emocional.

Com o avanço das novas tecnologias de transmissão e o surgimento de novos meios de comunicação, o rádio passou por mudanças significativas que impactaram negativamente sua capacidade de geração de recursos financeiros, mas que não alteraram a sua importância como difusor privilegiado de informações, graças à sua mobilidade e ao imediatismo com que atua na construção da notícia.

A incorporação do rádio às novas plataformas de comunicação, como a Internet, smartphones e outros dispositivos móveis, trouxe um novo alcance para esse veículo quase centenário, o que o mantém na condição de importante meio de transmissão de informação, conhecimento e entretenimento.

Existem atualmente em operação no Brasil 4.741 emissoras de rádio. Desse total, 1.777 operam em ondas médias (AM) e 2.964 em frequência modulada (FM). ${ }^{45}$

Segundo dados do $\mathrm{PNAD}^{46}$, o Brasil tinha em 2013, 65 milhões de domicílios. Deste total, $75,7 \%$ têm, pelo menos, um aparelho receptor de rádio, o que gera um público estimado de mais de 166 milhões de brasileiros - só em audiência domiciliar. É interessante notar que o número de receptores de rádio tem caído desde 2008. Os estudos indicam que esta queda está relacionada ao aumento do número de aparelhos de telefonia celular com rádio.

\footnotetext{
45 Dados da Anatel (Agência Nacional de Telecomunicações) - 2013 - Ver Anexo 4

${ }^{46}$ Pesquisa Nacional de Amostragem de Domicílios do IBGE (Instituto Brasileiro de Geografia e Estatística), dados obtidos em 2014.
} 
É fato, ainda, que $80 \%$ dos veículos automotores que compõem a frota brasileira (aproximadamente 59 milhões de veículos ${ }^{47}$ ) dispõem de receptores de rádio, o que amplia o número de ouvintes potenciais das emissoras brasileiras.

Além de transmitir informação e entretenimento, o rádio estimulou novos hábitos, criou ídolos, contribuiu decisivamente na construção de um espaço público marcado por valores identificados pela audiência como importantes e que iriam influenciar novos padrões de comportamento.

A contribuição do radiojornalismo para a construção de novos modelos de difusão da notícia foi decisiva na consolidação do jornalismo como atividade empresarial, estabelecendo as bases dos empreendimentos jornalísticos que viriam a se constituir nos primeiros conglomerados midiáticos de nosso país.

${ }^{47}$ Esse número representa a soma do número de automóveis, caminhões e utilitários, em novembro de 2014, de acordo com o Departamento Nacional de Trânsito (DENATRAN) http://www.denatran.gov.br/frota2014.htm, acessado em 31/03/2015 


\title{
CAPÍTULO IV - IMPÉRIO: UMA PALAVRA, MUITOS SIGNIFICADOS
}

Em seu livro A História Secreta da Rede Globo, Daniel Herz registra:

\begin{abstract}
A Rede Globo é o centro de um império que abrange mais de quarenta empresas, atuando em diversos ramos da economia. Só a Rede Globo que inclui sete emissoras totalmente de sua propriedade, seis emissoras de propriedade parcial e 36 emissoras afiliadas - tem uma receita anual estimada em U\$ 500 milhões e um valor patrimonial em U\$ 1 bilhão ${ }^{48}$. (HERZ, 2009:29)
\end{abstract}

A palavra "império" está presente na história da humanidade há mais de dois mil anos. Ao longo de todo este tempo seu significado tem sido alterado, ampliado e empregado de diferentes maneiras, em diversos campos do conhecimento: história, política, administração, economia, direito, artes e, até mesmo, na comunicação.

Originária da palavra latina imperium, que significa "aquilo que é dotado de autoridade legítima", ganhou força e seu emprego atual quase sempre suscita algum tipo de polêmica, uma vez que pode ser utilizado tanto num sentido positivo (força, unidade, eficiência), quanto numa acepção negativa (domínio, imposição, autoritarismo).

$\mathrm{Na}$ Europa medieval o conceito de império tinha uma conotação positiva, normalmente relacionada aos reinos da cristandade, seus ideais de paz e justiça, mesmo convivendo com a ameaça constante dos conflitos entre a Igreja e a nobreza pela liderança do processo político e pelo direito ao exercício do poder.

No campo da ciência política, a partir do século XVIII, o termo passou a ser relacionado a diferentes sistemas políticos, o que exige cuidado ao empregá-lo, pois pode dar sentido a estruturas completamente distintas, com diferentes mentalidades, instituições e níveis de intervenção social, remetendo a modelos de dominação política, econômica e militar.

${ }^{48}$ Números de 1987. Referências mais atuais (2012, 2013 e 2014) podem ser encontradas nas Notas de Rodapé №s 45, 52, 53 e 54 desta Tese. 
Já no campo econômico, o termo império passa a denotar uma estrutura de produção e comercialização diversificada e complementar, que detém grandes fatias do mercado e, dessa forma, consegue definir modelos de ação empresarial, estabelecer padrões de consumo e ampliar o alcance de sua marca.

Os grandes impérios econômicos surgiram no final do século XIX nos Estados Unidos e na Europa Ocidental, a partir das mudanças provocadas pela revolução industrial, principalmente a produção em massa, o uso da tecnologia e o desenvolvimento dos transportes e dos meios de comunicação.

E justamente esses dois últimos elementos foram decisivos para que os impérios avançassem e mantivessem o domínio político e econômico por longos períodos. O desenvolvimento dos transportes e a ampliação do alcance dos meios de comunicação permitiram aos impérios penetrar no imaginário dos povos dominados impondo-lhes novos valores culturais, utilizando a arte e a cultura para retirar-Ihes qualquer possibilidade de resistência.

O sucesso das estratégias adotadas pelos grandes impérios para alcançar seus objetivos de dominação depende, em grande parte, da capacidade de transmitir e impor modelos culturais. Portanto, a eficiência do domínio de grandes extensões territoriais irá resultar da eficiência dos meios de comunicação (INNIS, 1986, p. 5).

E quando são os próprios meios de comunicação que, utilizando-se de seu alcance e de sua capacidade de "dizer às pessoas no que pensar" (TRAQUINA, 2008:15), assumem uma postura imperial, ou seja, acreditam exercer uma "autoridade legítima"?

É possível perceber que nessa condição, os grupos midiáticos tornam-se instâncias dotadas de um poder discricionário, que imediatamente nos remete à acepção negativa da palavra império: domínio, imposição, autoritarismo: 
Sob o ponto de vista da Teoria Administrativa, um conglomerado empresarial é a combinação de duas ou mais corporações com atividades em diferentes tipos de negócio, mas que estão sob uma mesma estrutura corporativa (ou grupo empresarial), geralmente uma holding e várias subsidiárias. Muitas vezes, um conglomerado é formado por uma empresa multi-industrial ou por empresas multinacionais.

\begin{abstract}
Um conglomerado pode ser entendido como uma empresa que controla um leque de atividades em diversos negócios que requerem habilidades administrativas diferentes e que realiza um processo de diversificação basicamente através de aquisições e fusões. Os conglomerados podem ser financeiros ou administrativos. Um conglomerado financeiro é aquele que financia as demais empresas, controlando-as e assumindo os riscos financeiros das diversas atividades (MATIAS et all, 1996:7).
\end{abstract}

Se aplicarmos esse conceito às empresas ligadas ao campo profissional da Comunicação, poderemos definir conglomerado midiático como sendo um grupo empresarial que controla um grande número de empresas em diferentes meios de comunicação, como televisão, rádio, impresso, cinema, música e internet.

Os primeiros conglomerados midiáticos surgiram nos Estados Unidos, ainda no século XIX e servem, perfeitamente, como modelo para o que denominamos "impérios midiáticos", fenômeno que se repetirá em diversas partes do mundo, inclusive no Brasil, onde terá um impacto notável na difusão da informação e um peso significativo na atividade política e no ambiente econômico a partir dos anos de 1950.

O surgimento, na primeira metade do século $X X$, de dois grandes conglomerados midiáticos no Brasil (os Diários Associados e o Grupo Globo ${ }^{49}$ ) constitui-se em fato relevante que suscita uma série de questionamentos, principalmente no que diz respeito ao poder da mídia e de como esse poder é utilizado por seus donos de maneira imperial, a partir de interesses muito específicos e com a finalidade única de ampliar e consolidar sua influência na política, na economia e na vida cultural do país.

\footnotetext{
${ }^{49}$ Apesar de ter sua origem na década de 1920, com a fundação do jornal O Globo (1926), o Grupo Globo só viria a se transformar num conglomerado midiático a partir da década de 1970, com a consolidação da Rede Globo de Televisão.
} 
Francisco de Assis Chateaubriand Bandeira de Melo e Roberto Pisani Marinho são nomes definitivamente inscritos na história do Brasil. As homenagens que receberam materializam-se em incontáveis praças, avenidas, ruas, escolas e até mesmo numa cidade no Oeste do Paraná, onde os que lá nascem têm como gentílico o adjetivo "chateaubriandense".

Ambos tornaram-se empresários bem sucedidos partilhando problemas e dificuldades numa república que teimava em manter, no início dos anos 1930, as estruturas sociais, políticas e econômicas de um regime monárquico morto por um golpe militar havia quase quatro décadas.

Embora tenham tido origens e trajetórias pessoais diferentes, essas instigantes personalidades se assemelham na capacidade empreendedora, na habilidade em perceber as peculiaridades do ambiente político e de interagir com essas forças, sempre visando o sucesso de seus negócios. Construíram e expandiram empresas em condições econômicas e políticas em que prevaleciam o paternalismo estatal, a corrupção e o adesismo incondicional.

Como empreendedores, tiveram participação importante na construção de um campo profissional que movimentou em 2013 cerca de $\mathrm{R} \$ 47,9$ bilhões ${ }^{50}$, gerando milhares de emprego e influenciando, fortemente, a formação da opinião pública.

Assis Chateaubriand e Roberto Marinho têm sido retratados, ao longo do tempo, de forma quase sempre passional: biografias, teses e estudos em que suas ações e suas personalidades são descritas de forma adulatória ou denunciatória. São amados ou odiados com a mesma intensidade. Portanto, é preciso desapaixonar essa análise para que possamos compreender como Ihes foi possível formar e fazer prosperar suas empresas.

Eles iniciaram seus impérios econômicos vendendo jornais numa época em que $80 \%$ da população do país eram analfabetos e dentre os que sabiam ler, poucos tinham dinheiro para gastar com notícias. Como conseguiram criar, sustentar e expandir empresas jornalísticas num contexto econômico imprevisível, sem que 
houvesse um mercado consumidor forte o suficiente para comprar espaço publicitário e assim assegurar certa independência editorial?

É certo que fizeram concessões políticas, mas tiveram, também, de traçar estratégias e tomar medidas econômicas e administrativas que Ihes permitiriam sobreviver às tempestades políticas - que não foram poucas. Isso demonstra que ambos possuíam talentos específicos e qualidades inequívocas como administradores, capitães-de-indústria e homens de empresa.

Quantos tentaram, na mesma época, no mesmo Brasil, o caminho do jornalismo como atividade econômica e foram vencidos pelos mesmos obstáculos superados por Chateaubriand e Marinho? Quantos sucumbiram diante do poder dos partidos e dos interesses econômicos?

Muito embora possamos identificar nos veículos criados por esses empreendedores as mesmas condições limitadoras características da produção jornalística da época em que se estabeleceram, há algo que os diferencia daqueles que investiam na imprensa apenas como elemento de apoio aos seus projetos políticos e comerciais: ambos sabiam que a maneira mais eficiente de usar seus veículos jornalísticos era lançando mão dos recursos que o próprio jornalismo passara a oferecer, graças às mudanças na maneira de produzir e divulgar as notícias, abrindo espaço para a informação, numa linguagem mais acessível e com o uso de novos recursos gráficos:

\begin{abstract}
Além de se preocupar com a estética, Chateaubriand insistia nas reportagens: seu primo Rafael Correa de Oliveira [...] é colocado no encalço da Coluna Prestes, e pela primeira vez o público lê na grande imprensa algo que até então só aparecia em panfletos políticos: entrevistas em que os chefes rebeldes descrevem suas refregas contra as forças regulares do governo federal (MORAIS, 1994:159).
\end{abstract}

E isso implicou, muitas vezes, em abrir espaço para a veiculação de produtos e notícias que aparentemente contrariavam seus interesses e projetos, como a notória presença de simpatizantes e até mesmo militantes do Partido Comunista na redação de $O$ Globo e entre autores e atores da TV Globo:

O esforço da Globo para garantir a expressão dos interesses de seus proprietários, entretanto, não impede que lá se manifeste uma série de processos difíceis de controlar integralmente, o espírito crítico do jornalista, do radialista, do artista, enfim, dos diversos profissionais que lá trabalham. Seja por uma questão de mercado, seja pela combatividade dos 
profissionais, a Globo é obrigada a tolerar, ou mesmo engolir, certas ocorrências que contrariam a filiação ideológica de seus proprietários (HERZ, 2009:24).

Chateaubriand e Marinho foram figuras centrais da história política brasileira em boa parte do século XX, influenciando, agitando, inovando e desconstruindo o jornalismo até então praticado no Brasil. Dando novo sentido à notícia, inventando novos formatos e produtos para alcançar um público que buscava a informação como meio de entender as mudanças que ocorriam ao seu redor, numa velocidade cada vez maior e como essas mudanças afetavam a sua vida.

A liderança que exerceram no campo jornalístico resultou, naturalmente, numa capacidade de influenciar o campo político e com isso mobilizar recursos, arregimentar seguidores e enfrentar opositores e inimigos, utilizando seus veículos de comunicação. Sem dúvida, são histórias de vida e do jornalismo que se entrelaçam à história recente do País e que nos permitem perceber como o jornalismo brasileiro se consolidou enquanto atividade econômica e fonte de poder.

\subsection{O "VELHO CAPITÃO"}

Nascido em Umbuzeiro (PB), em 4 de outubro de 1892, filho de um funcionário público, Francisco de Assis Chateaubriand Bandeira de Mello permaneceu analfabeto até os 10 anos de idade. Sua educação formal foi feita no Recife (PE) e sua carreira no jornalismo começa aos 15 anos. Foi repórter, editor e editor-chefe do Diário de Pernambuco com apenas 21 anos. Foi nessa mesma época que se formou em Direito. Em 1915, preterido num concurso para o cargo de professor da Faculdade de Direito do Recife, embarca para o Rio de Janeiro, onde consegue a nomeação com a interferência do Presidente da República.

Com a ajuda dos muitos contatos que estabeleceu na então capital federal, Chateaubriand volta ao Rio de Janeiro em 1917 para exercer a advocacia. Logo se destaca em causas polêmicas e amplia suas relações com empresários e políticos importantes. Nesse mesmo período passa a colaborar com diversos jornais, sendo convidado a assumir o cargo de redator-chefe do Jornal do Brasil, onde ficou até 1920.

Percorreu a Europa como correspondente do Correio da Manhã (à época, o mais influente jornal brasileiro) e ganhou experiência como repórter. Ao regressar ao 
Brasil, no final de 1920, percebe que suas ligações com grupos econômicos poderosos poderiam ajudá-lo a tornar-se dono do próprio jornal. Em 1924, aos 31 anos de idade, Chateaubriand é o proprietário do $O$ Jornal, um dos diários que então circulavam no Rio de Janeiro.

Fundado em 1919 por um grupo de jornalistas saídos do Jornal do Commércio, O Jornal foi criado com o objetivo de ajudar na implantação de empresas siderúrgicas estrangeiras no Brasil. Com a "eleição do ultranacionalista Artur Bernardes", seus proprietários o venderam "de mão beijada" ao jornalista Toledo Lopes (MORAIS, 1994:136), que resolveu, então, passá-lo adiante.

Chateaubriand conseguiu os recursos necessários (6 mil contos de réis) e comprou o 0 Jornal, com o qual iniciaria o seu futuro império. Com ele viria, também, a primeira de muitas e muitas dívidas com as quais lidaria pelo resto da vida.

A personalidade polêmica e instigante de Chateaubriand foi muito bem descrita e analisada em diversas obras ao longo das últimas décadas. Não há nenhuma dúvida quanto ao seu comportamento pouco ético e sua visão peculiar em relação ao Brasil e seus problemas, quase sempre marcada por preconceitos e atitudes inusitadas, o que fizeram dele uma figura odiada e temida.

\footnotetext{
Muita gente odeia, condena, diverge, ataca e não compreende essa figura realmente confusa para a História, que é Assis Chateaubriand. Duas pessoas, entre outras muitas das 20 mil famílias que vivem na sua dependência, duas pessoas o estimam sinceramente. Juscelino e eu. Com uma diferença: Juscelino precisa dele (NASSER, 1962: 27).
}

Não se intimidava diante das muitas tentativas, e por diferentes governos, de restringir a ação política de seus veículos de comunicação. Chateaubriand não escondia suas diferenças e seus desafetos. Pelo contrário, expunha-os em seus artigos pontuados por ironias e, muitas vezes, por bravatas.

Nesses últimos anos, minha vida foi estar de carabina na porta dos Associados para defender este patrimônio. E acho que se eu não fosse paraibano, e do sertão, esse gaúcho [Getúlio Vargas] já tinha me comido (CHATEAUBRIAND apud NETO, 2013:475).

Também não perdia oportunidade de obter recursos ou favores que pudessem fortalecer e ampliar os seus domínios. Empréstimos, financiamentos junto aos agentes públicos, acordos improváveis e outros expedientes faziam parte de 
suas estratégias empresariais, que contemplavam, invariavelmente, a utilização de seus veículos de comunicação na obtenção de vantagens comerciais.

Por outro lado, é inegável a importância que Chateaubriand teve para o desenvolvimento do jornalismo informativo no Brasil. Ele foi o responsável por boa parte das mudanças que fizeram com que o jornalismo brasileiro finalmente se aproximasse do leitor. Um dos melhores exemplos dessa nova postura em relação ao formato jornalístico foram as grandes reportagens de $O$ Cruzeiro, com sua pauta variada, plena de interesse humano.

Ao adquirir o O Jornal, no Rio de Janeiro, no início dos anos de 1920, Chateaubriand substituiu "os intermináveis e soníferos artigos que ocupavam meia, uma e até duas páginas por uma novidade que fazia muito sucesso na imprensa dos Estados Unidos - as reportagens" (MORAIS, 1994:143).

É ainda de Chateaubriand a iniciativa de implantar a televisão no Brasil e com ela criar novos hábitos, interferindo na produção cultural e estabelecendo novos modelos para o jornalismo que assim se beneficiaria do encantamento provocado pelo testemunho da imagem.

A força e o alcance do império construído por Assis Chateaubriand mudaram, definitivamente, a face do jornalismo brasileiro. A diversificação dos investimentos e das fontes de receita geradas pelas empresas do grupo deu a Chateaubriand uma força até então inimaginável.

Com ele, o jornalismo, no Brasil, deixa de ser uma atividade unicamente subordinada ao poder político, claramente ligada aos objetivos e interesses dos grupos que dominavam a cena política. Deixa a condição de ferramenta da ação política e ganha a dimensão de uma atividade econômica, com interesses próprios, uma visão muito particular dos problemas nacionais e que vai usar toda a sua força e capacidade de mobilização da sociedade em benefício de seus próprios projetos e interesses. Era o fim da ingenuidade.

Em apenas três décadas, o império construído por Chateaubriand cobriria praticamente todo o país. Os jornais, revistas, emissoras de rádio e de televisão que 
formavam os Diários Associados exerciam enorme influência sobre a opinião pública e davam ao seu fundador um prestígio que utilizava para aumentar seu poder.

Por duas vezes elegeu-se senador e foi nomeado embaixador do Brasil junto à Inglaterra por Juscelino Kubitschek, além de influenciar decisivamente na nomeação de ministros e altos funcionários do governo.

Usou, ainda, sua influência para promover ações de natureza cultural, como a criação do Museu de Arte de São Paulo (MASP) ou de apelo cívico, como a campanha para ampliar o número de aeroclubes no Brasil, mas sem perder de vista as oportunidades que tais ações lhe garantiam para aumentar seus interesses ou, pelo menos, divulgar seus veículos de comunicação.

Os Diários Associados chegaram a reunir trinta e seis jornais, dezoito revistas, trinta e seis emissoras de rádio e dezoito de televisão, num processo contínuo de aquisição, incorporação e criação de novos veículos com o objetivo de ampliar o alcance e a presença do grupo nos mais diversos pontos de país.

Depois de adquirir o O Jornal, em 1924, Chateaubriand chegou ao final da década de 1920 como proprietário de outros seis veículos de comunicação: Diário da Noite, de São Paulo (1925); O Cruzeiro - primeira revista de variedades, de circulação nacional e que viria a se tornar um verdadeiro ícone para o grupo ${ }^{51}$ (1928); Diário de Notícias, do Rio Grande do Sul (1929); Diário de São Paulo (1929); O Estado de Minas (1929); e Diário da Noite, do Rio de Janeiro (1929) ${ }^{52}$.

$\mathrm{Na}$ década de 1930, o crescimento do grupo é vertiginoso, transformando-o no primeiro conglomerado midiático brasileiro. Um contrato com a Wide World Photo permite que seus jornais recebam fotos de acontecimentos internacionais em todo o mundo.

${ }^{51}$ O Cruzeiro ocupa um lugar especial na história do jornalismo brasileiro. Inspirada na francesa Paris Match, circulou entre 1928 e 1975. Responsável por inúmeras inovações, tanto na construção da notícia quanto nos recursos gráficos, a revista formou várias gerações de jornalistas, destacou o trabalho de repórteres e fotógrafos e publicou inúmeras reportagens polêmicas. A cobertura fotográfica e a qualidade da impressão eram os grandes diferenciais de $\boldsymbol{O}$ Cruzeiro, sem dúvida, o mais importante e bem sucedido empreendimento jornalístico de Chateaubriand.

52 As informações a respeito da expansão dos Diários Associados (aquisições e criação de veículos) têm como fonte $\quad$ site: Memória Diários Associados. Disponível em http://www.diariosassociados.com.br/linhadotempo/decada20.html, acessado em 27/04/2015 
Em 1931, passam a integrar o grupo o Diário da Tarde (vespertino fundado por Chateaubriand e que circulava em Minas Gerais), o Diário de Pernambuco (o mais antigo jornal em circulação no Brasil, fundado em 1825, pioneiro na publicação de classificados e de publicidade e adquirido pelos Diários), Agência Meridional de Notícias (primeira agência de notícias brasileira a fornecer conteúdo para a radiodifusão) e a Rádio Mineira, fundada em 1925 e adquirida naquele ano pelo grupo.

Em 1932, Os Diários incorporam o Diário Mercantil de Juiz de Fora (MG), jornal fundado em 1912 e de forte tradição no jornalismo político e, em 1934, o grupo compra a revista semanal ilustrada A Cigarra, que circulava desde 1914.

Em 1935, entra no ar a Rádio Tupi do Rio de Janeiro, que ficou conhecida como "O Cacique no Ar". Foi uma importante escola para técnicos, produtores, cantores, locutores e atores radiofônicos, além de dedicar grande parte de sua programação ao jornalismo e ao esporte.

No ano seguinte, os Diários Associados incorporam ao grupo o Jornal de Alagoas, que circulava em Maceió desde 1908; e o Monitor Campista, terceiro jornal mais antigo do país, fundado em 1834 e que circulava na região Norte do Estado do Rio de Janeiro.

Três novos veículos se juntam aos Diários Associados, em 1937. São eles: o Diário de Santos, jornal especializado em economia; a Rádio Tupã, de São Paulo, que logo passaria a denominar-se Rádio Tupi de São Paulo; o Correio do Ceará, o mais antigo jornal cearense, fundado em 1915. As empresas de Chateaubriand adquirem, ainda naquele ano, o Diário do Paraná, o Estado da Bahia e a Rádio Difusora, de São Paulo.

Em 1940, passam a fazer parte dos Diários Associados o jornal Unitário de Fortaleza, a Rádio Difusora, de Teresina (PI) e a Rádio Sociedade da Bahia, a segunda mais antiga do Nordeste.

Mais três veículos são adquiridos pelo grupo em 1942: Diário de Notícias, da Bahia, fundado em 1875; a Rádio Clube de Goiânia; e a Rádio Guarani, em Belo Horizonte. 
Um ano depois, Chateaubriand soma ao seu império o número recorde de oito novas empresas: o jornal A Razão, de Santa Maria (RS); a Rádio Educadora do Brasil; a Rádio Farroupilha, no Rio Grande do Sul, cujo sinal chegava aos países do Cone Sul: Argentina, Uruguai, Chile e também ao Paraguai; o Jornal do Commércio, de Manaus; o vespertino A Vanguarda, do Pará; a Rádio Baré, no Amazonas; o jornal Alto Madeira, em Porto Velho (RO); e a Rádio Difusora Porto-alegrense, no Rio Grande do Sul.

Outros quatro veículos passam a fazer parte do grupo em 1944: Rádio Poti, de Natal (RN); Rádio Tamoio, que substitui a Rádio Educadora do Brasil, no Rio de Janeiro; o jornal O Imparcial, de São Luís (MA); e a Ceará Rádio Clube, em Fortaleza (CE).

Em 1945, é a vez do jornal O Diário, de Natal (RN), que havia sido fundado em 1939 para combater o Nazismo e o Fascismo. A Província, do Pará, o mais antigo periódico da Amazônia, junta-se aos Diários Associados em 1947. E o espírito empreendedor de Chatô chega a sua terra natal, a Paraíba, em 1949, com a Rádio Borborema, de João Pessoa.

A década de 1950 representa para os Diários Associados uma nova fase em suas atividades, com a inauguração, em 18 de setembro daquele ano, da primeira emissora de televisão da América Latina: a PRF-3 TV Tupi, de São Paulo.

A TV Tupi do Rio de Janeiro vai ao ar em 20 de janeiro de 1951, na presença do então Presidente da República Eurico Gaspar Dutra. Ainda no mesmo ano, os Diários Associados inauguram a Rádio Tamandaré, em Recife. Esta emissora foi a primeira a veicular anúncios publicitários nos intervalos entre os programas.

Em 1952, o grupo adquire a Rádio Clube de Pernambuco, considerada por alguns historiadores como a mais antiga do Brasil $^{53}$ e, em seguida, compra a Rádio Difusora do Piauí.

\footnotetext{
53 Existem registros de que a Rádio Clube de Pernambuco começou a operar em 1919, como atividade desenvolvida por um grupo de jovens do Recife com finalidade recreativa e científica.
} 
No ano seguinte, Chatô volta a adquirir um veículo de comunicação na Paraíba. Ele incorpora o jornal $O$ Norte ao grupo de empresas pertencentes aos Diários Associados.

São mais duas aquisições em 1954: a Rádio Marajoara, de Belém e o jornal $O$ Poti, de Natal (RN).

Belo Horizonte ganha sua primeira emissora de televisão em 1955: TV Itacolomi, a primeira emissora projetada e montada, exclusivamente, por técnicos brasileiros.

Chateaubriand retorna à Paraíba em 1956 e compra a Rádio Cariri, que havia sido a pioneira na radiodifusão daquele estado.

Em 1957, são mais três veículos de comunicação que se juntam ao grupo Associados: a Rádio Verdes Mares, de Fortaleza; o Diário de Borborema, de Campina Grande (PB); e o centenário Jornal do Commércio, do Rio de Janeiro, fundado em 1827.

Dois anos mais tarde, os Associados tentam expandir a circulação de seus veículos para a América Latina e lançam a edição em espanhol de O Cruzeiro. No Rio Grande do Sul inauguram a primeira emissora de TV do estado, a TV Piratini e adquirem o jornal A Hora, de Porto Alegre. Incorporam, ainda, a Rádio Cultura, de São Paulo.

Nesse mesmo ano, 49\% das ações e quotas das empresas de Assis Chateaubriand passaram a integrar o patrimônio do Condomínio dos Diários Associados, formado por vinte e dois condôminos, escolhidos por Chateaubriand entre seus mais próximos colaboradores.

Por meio desse engenhoso sistema, o Condomínio passou a responder pela administração de todo o grupo. Ficou estabelecido que, falecido ou excluído um dos integrantes, os remanescentes deveriam escolher no voto a quem seria atribuída a fração ideal vacante.

No dia 27 de fevereiro de 1960, Chateaubriand é acometido por uma trombose que 0 incapacitaria fisicamente para 0 resto da vida. Apesar das 
dificuldades de locomoção e comunicação, Chatô permaneceu por quase oito anos à frente de seu império. Na primeira oportunidade em que conseguiu comunicar-se, com muita dificuldade, definiu o que Ihe havia acontecido:

\begin{abstract}
Usando de um eufemismo, ele deixava claro que tinha noção da profundidade da tragédia que se abatera sobre si, paralisando completamente seu corpo, mas deixando a mente intacta. Letra por letra, espaço por espaço, lá estava escrito no caderno de Emília: "Já entendi tudo: o edifício pegou fogo, só sobrou a biblioteca” (MORAIS, 1994:620).
\end{abstract}

Naquele mesmo ano, os Diários Associados passam a contar, entre suas empresas, com mais quatro veículos de comunicação: o jornal Correio Braziliense, que circulou pela primeira vez no dia da inauguração de Brasília, cumprindo uma promessa que Chateaubriand fizera ao Presidente Juscelino Kubistchek, de que a nova capital seria inaugurada já contando com um novo jornal diário.

Além do jornal, Brasília dispõe, também a partir do dia de sua inauguração, de uma emissora de TV, a TV Brasília. O grupo inaugurou ainda, naquele mesmo ano, a TV Itapoan, em Salvador, a TV Rádio Clube, de Recife e a TV Cultura, em São Paulo.

A expansão da rede de televisão avança rapidamente. Em 1961, o grupo põe no ar mais sete emissoras: TV Rádio Clube de Goiânia, TV Marajoara (em Belém), TV Vitória, TV Ceará, TV Florianópolis, TV Campo Grande e TV Aracaju.

Na segunda metade da década de 1960, os Diários Associados passam a enfrentar a forte concorrência das empresas de Roberto Marinho, do Grupo Globo, principalmente após a inauguração da TV Globo, no Rio de Janeiro, em 26 de abril de 1965.

Contando com a assistência técnica e com apoio financeiro do grupo norteamericano Time-Life, a Globo avança rapidamente e logo se torna a emissora líder, ampliando e consolidando a sua presença em outras partes do Brasil.

A associação com a Time-Life dá origem a uma investigação na Câmara dos Deputados, a partir da denúncia do então Deputado João Calmon, um dos mais próximos colaboradores de Chateaubriand. A Comissão Parlamentar de Inquérito concluiu que o acordo entre a empresa de Roberto Marinho e o grupo americano feria a Constituição Federal, obrigando a Globo a desfazer o negócio. 
Mas a emissora de Marinho já assumira a liderança inconteste da audiência, o que ajudou no crescimento das demais empresas e veículos do grupo, que em menos de vinte anos, se tornaria um dos maiores grupos de mídia do mundo.

Chateaubriand não viveria para testemunhar o sucesso de Marinho. Ele morre em 1968 e seus herdeiros legais dão início a uma batalha judicial que atravessará as décadas seguintes, na tentativa de tornar nula a iniciativa de Chatô de transferir suas ações e direitos do grupo para o Condomínio dos Diários Associados.

$O$ antigo império encolheu e transformou-se num conglomerado de empresas regionais. O fim da revista O Cruzeiro, em 1975 e o fechamento da TV Tupi, em 1980, marcam os momentos mais difíceis vividos pelo grupo, que apesar de ainda contar com um número considerável de veículos, enfrenta uma série de problemas, a exemplo do que ocorre atualmente com o jornal Estado de Minas, conforme relata o artigo de Ângela Carrato, publicado em janeiro de 2015 na edição ํo 833, do Observatório da Imprensa, sob o título "A Agonia dos Diários e Emissoras Associados": ${ }^{54}$

\begin{abstract}
A sede do jornal Estado de Minas está à venda, deixando explícita a gravíssima crise que a empresa enfrenta, envolvendo má gestão, perda de credibilidade e o consequente desaparecimento de leitores e anunciantes. A título de exemplo, o jornal, que é o mais antigo e tradicional da capital mineira, tem circulado com apenas dois cadernos, num total de 24 páginas, ao contrário de um ou dois anos atrás, quando, mesmo em dias de edição mais fraca, eram quatro ou cinco.
\end{abstract}

O que mais nos impressiona quando nos aproximamos da figura excepcional que foi Assis Chateaubriand, para tentar estabelecer sua importância para a história do jornalismo brasileiro, é a diversidade de opiniões e juízos de valor a seu respeito.

Como jornalista, Chatô produziu muito. Somente nos Diários Associados ele publicou, ao longo de quarenta e quatro anos, exatos 12.225 artigos, nos quais sua personalidade, sua visão de mundo e seus valores se exibem fartamente.

Um de seus amigos mais próximos, o jornalista e acadêmico Austregésilo de Athayde, que o acompanhou por toda a vida, não escondia a admiração que the causava tanta contradição numa só pessoa: 
Havia nele uma legião, não só múltipla, mas também variada e contraditória, anjo e demônio, em mutações rápidas, sucessivas, enormemente fugazes que mesmo o psicólogo mais arguto não saberia condicionar num arquétipo, numa imagem única: Chateaubriand era assim (...) apresentava-se multiforme, inesperado e movido por uma imaginação criadora (...) projeção incrivelmente refratária à lógica formal (ATHAYDE apud CARNEIRO, 1999:57).

Como empresário Chateaubriand encaixa-se, quase que à perfeição, no tipo ideal que construímos inspirados na definição de Cardoso (1964) para a ação social do "capitão-de-indústria": avesso à poupança e com uma compreensão limitada dos problemas, o que o leva, por meio da manipulação dos fatores sob seu controle, a buscar a rápida acumulação de capitais.

Paga baixos salários e valoriza o trabalho pesado. Para Cardoso, esse tipo de empreendedor não seria capaz de ajudar o país a superar os problemas de sua economia pré-capitalista.

Para Chateaubriand, os seus empregados deviam honrar-se de trabalhar para a grandeza dos "Diários". Pagava-os mal, negava-lhes as gratificações usuais, detestava compartissem outras tarefas, flanassem ou gozassem férias. (...) Queria-os integrados e anônimos. Mas, apresentava inculcadas reservas de candura e romantismo, como recitar para os mais chegados, poemas de Bilac a Baudelaire, e cantar um lieder alemão, ingênuo e melancólico, às vezes brotando nele um gesto de inesperada generosidade, tanto mais exagerada quanto excepcional, como no episódio da casa doada para o gráfico (RIZZINI apud CARNEIRO, 1999:116).

Em maio de 2014, após 40 anos de discussões na Justiça, os acordos e contratos que deram origem ao Condomínio Acionário das Emissoras e Diários Associados, celebrados entre 1959 e 1962, foram considerados legais.

A Terceira Turma do Superior Tribunal de Justiça (STJ), por maioria de votos, negou o recurso de Thereza Acunha Bandeira de Mello Alkmin, filha do jornalista, que queria que as ações do grupo ficassem com os herdeiros.

Chatô continua invencível.

\subsection{CIDADÃO KANE}

Roberto Pisani Marinho, nascido em 3 de dezembro de 1904, no Rio de Janeiro, é frequentemente comparado ao personagem Charles Foster Kane, criado por Orson Welles, em 1941 no filme Cidadão Kane, por sua vez inspirado na figura 
do milionário americano William Hearst, dono do maior império jornalístico dos Estados Unidos na primeira metade do século XX.

Marinho herdou do pai, Irineu Marinho, o jornal $O$ Globo, fundado em julho de 1925. Irineu construíra uma carreira vitoriosa como jornalista no Rio de Janeiro do início do século XX. Foi um dos fundadores do jornal $A$ Noite ${ }^{55}$ e responsável por importantes inovações no jornalismo brasileiro.

A Noite teve dois grandes eixos de organização das suas pautas: o cotidiano da cidade e a política em todos os níveis, com ênfase no nacional. No que se refere à cidade, $A$ Noite abordará não somente temas como a abertura de ruas, canalização de rios, iluminação pública, como também aqueles mais propriamente recobertos pela noção de etos urbano, isto é, o modo de vida dos citadinos: a "fezinha" nos jogos de azar, a paciência diante de epidemias ou enchentes, a entrega absoluta aos festejos de Momo (CARVALHO, 2012:110).

Na condição de empresário, Irineu Marinho sempre se preocupou em manter o jornal financeiramente equilibrado e, com isso, gozar de independência em relação ao governo ou a grupos políticos, o que era quase impossível na imprensa brasileira da época.

Suas iniciativas fariam o jornal ampliar o número de leitores, promovendo alterações significativas na forma e na maneira de construir a notícia, tendo, inúmeras vezes, ele mesmo provocado os fatos que viriam a se tornar manchete de seu jornal.

No esforço empresarial, Irineu Marinho foi além do jornal. Demonstrando agora autêntico pioneirismo, diversificou seus negócios, investiu na indústria do entretenimento, na produção cinematográfica, na música popular. Aproximar-se do povo e da cidade para se libertar financeiramente revelouse inicialmente boa política e bom negócio (Ibidem:111).

Além de investir na música, no teatro e no cinema ${ }^{56}$, Irineu, por intermédio de A Noite, patrocinou corridas de automóvel, competições esportivas, promoveu eventos inéditos, como o concurso da mais bela mulher do Brasil e a organização de um desafio aéreo que daria dez contos de Réis ao aviador que decolasse do centro da cidade e chegasse até a Ilha do Governador.

\footnotetext{
${ }^{55}$ A Noite foi fundado em 1911 e circulou até 1957.

${ }^{56}$ Em 1917, Irineu Marinho fundou a Veritas Film, que produziu filmes sobre crimes e a vida mundana no Rio de Janeiro da Belle Époque. O mais notável deles foi "A quadrilha do Esqueleto", de 1917, que trazia cenas espetaculares de ação filmadas nos cabos que sustentam o bondinho do Pão-de-Açúcar, no Rio de Janeiro.
} 
Foi um grande acontecimento e o destino encarregou-se de ampliar o grau de dramaticidade do evento promovido por Marinho. Após decolar em meio a uma multidão reunida na Avenida Central (atual Avenida Rio Branco), no centro do Rio, o avião pilotado por um ás da aviação francesa, Edmond Plauchut, despencou nas águas da Baía de Guanabara. O piloto saiu ileso, o avião afundou nas proximidades do Cais do Porto e as vendas de A Noite dispararam no dia seguinte.

[...] Os três primeiros anos de $A$ Noite se passaram em meio a grande turbulência nacional, fazendo com que a pauta política avançasse muito no espaço do jornal. Mesmo assim, A Noite emplacou importantes campanhas de cunho social, como, por exemplo, contra a crise da habitação; uma campanha que se dizia de "conteúdo cívico", voltada ao desenvolvimento da aviação nacional; e algumas campanhas promocionais de sucesso iniciativas que the renderam notoriedade e novos leitores (Ibidem:116).

Ao fundar $O$ Globo, Irineu tentava reerguer-se após perder o controle de $A$ Noite, vítima da perseguição política do governo do Marechal Hermes da Fonseca e de desencontros com seus sócios. Na verdade, Irineu tinha a esperança de que poderia implantar um jornal inovador, diferente do padrão da imprensa da época, mais próximo do leitor e de seus problemas cotidianos. Um jornal que fosse comercialmente viável.

Os problemas de Irineu com seus sócios serviriam de lição para o futuro empresário Roberto Marinho, fazendo com que procurasse se resguardar de qualquer surpresa em suas relações comerciais. Segundo Cláudio Mello e Souza, jornalista e assessor de Roberto Marinho, a desventura do pai com a perda de $A$ Noite para os sócios marcaria definitivamente a personalidade do empresário, que "aprendeu, a partir desse triste exemplo, que teria que ser mais esperto do que os espertos para sobreviver nesse ramo." 57

Com a experiência acumulada ao longo de todos os anos em que dirigiu $A$ Noite e com recursos obtidos por meio de empréstimos, Irineu funda $O$ Globo, cujo primeiro número circulou no Rio de Janeiro no dia 29 de julho de 1925. Três semanas depois, aos 49 anos, morre em razão de um infarto, deixando além de cinco filhos e uma viúva, um jornal recém-fundado.

57 Cláudio Mello e Souza em entrevista incluída no documentário Roberto Marinho: o senhor do seu tempo, produzido em 2011 pela produtora Canyon e dirigido por Rozane Braga e Dermeval Netto. Disponível em https://www.youtube.com/watch?v=MqZWL5WcEYQ, acessado em 09/04/2015 
Com a morte do pai, Roberto Marinho, primogênito e herdeiro legítimo, pragmaticamente confiou a direção de $O$ Globo ao veterano jornalista Eurycles de Mattos, chefe de redação e homem de confiança de seu pai e voltou à reportagem e aos prazeres da boa vida que levava no Rio de Janeiro da década de 1920.

Não sei se desta vez estou realmente me cansando da vida agitada. É a
primeira vez que te faço promessa escrita, e a esta não faltarei: a de
retomar firme o trabalho, evitar os telefonemas exagerados e as demais
coisas que possam desprestigiar o Globo. Não quero dar mais a ninguém o
'gostinho' de poder fazer comentários maldosos a meu respeito. ${ }^{58}$

Se Marinho manteve inteiramente a promessa feita à mãe não sabemos, o certo é que ele conseguiu, a partir de um jornal vespertino, que apostava numa linguagem mais simples e numa pauta que tratava dos problemas cotidianos da população, construir um dos maiores impérios de comunicação do mundo.

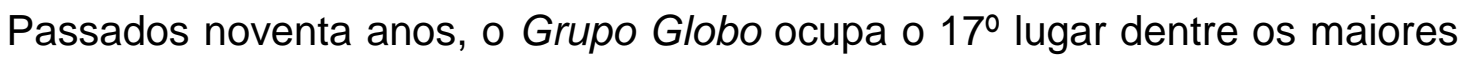
grupos de mídia do planeta $^{59}$, com uma receita líquida em 2012 de $R \$ 12,7$ bilhões $^{60}$. Seus herdeiros são donos de um patrimônio avaliado em U\$ 20 bilhões. ${ }^{61}$

São 24 mil empregados e uma infinidade de empresas e interesses em vários setores. Dentre elas destacam-se a Rede Globo de Televisão (cinco emissoras e 116 afiliadas), a rede de notícias $C B N$ (rádio), diversas emissoras de rádio $A M$ e FM espalhadas pelo Brasil, a Globosat (programadora de canais por assinatura, com 18 canais), a Infoglobo, empresa que edita os jornais O Globo, Extra e Expresso e que tem participações nos jornais Valor Econômico e Planeta Móvel.

Pertencem ainda ao grupo a Editora Globo (13 revistas semanais e mensais, além de livros), a Som Livre, gravadora e distribuidora musical e a Globo.com (fornecedora de serviços de Internet), além da Fundação Roberto Marinho, responsável por projetos culturais e pela preservação da memória do grupo.

Assim como Chateaubriand, Roberto Marinho tornou-se uma figura polêmica e onipresente no cenário político e empresarial. O seu nome e a sua trajetória como

\footnotetext{
${ }^{58}$ Trecho da carta escrita por Roberto Marinho, em 12 de setembro de 1929, e endereçada à mãe, publicada no livro Roberto Marinho, do jornalista Pedro Bial, pág. 94.

${ }^{59}$ Fonte: Zenith Optmedia, com base nas receitas publicitárias de 2011

${ }^{60}$ Fonte: Folha de São Paulo, 28/03/2013

${ }^{61}$ Fonte: Índice de Bilionários Bloomberg, 2012
} 
proprietário de mídia são constantemente relacionados a fatos e momentos importantes da história recente do Brasil. São muitas as pesquisas que têm como objeto o Grupo Globo e o papel que ele tem desempenhado na construção de nossa realidade social e política e na nossa memória coletiva.

Não se pode abordar o desenvolvimento dos meios de comunicação de
massa no Brasil, a partir da década de 60 , sem tocar na Rede Globo. Essa
Rede, a partir da década de 70 , passou a absorver mais de $40 \%$ da
totalidade das verbas publicitárias disponíveis no País e desse modo
condicionou todo o desenvolvimento dos meios de comunicação de massa
(HERZ, 2009:25).

No que se refere ao nosso interesse específico, ou seja, entender de que maneira as mudanças que se observam no jornalismo brasileiro a partir do final do século XIX criaram as condições necessárias ao surgimento dos impérios midiáticos de Chatô e Marinho, nos parece claro que, a exemplo do que ocorreu com os Diários Associados, o surgimento e a consolidação do império formado pelo Grupo Globo se devem, em grande parte, à personalidade diferenciada de seu fundador.

Sua capacidade de ler o ambiente político e econômico com perspicácia, perceber o movimento das forças que controlavam esse ambiente e de tomar decisões que permitiam à empresa manter-se sólida, independentemente das tempestades provocadas pela política ou das dificuldades de operar numa economia instável e, muitas vezes, imprevisível.

Um documentário produzido pela rede britânica Channel Four, em 199362, dirigido pelo documentarista Simon Hartog, Beyond Citizen Kane, retrata Roberto Marinho como uma figura poderosa, personagem importante no cenário político brasileiro pós-golpe militar de 1964 e dá a entender que o predomínio da TV Globo no ambiente midiático brasileiro fazia parte de um projeto de modernização e integração nacional bancado pela ditadura militar com capital norte-americano, notadamente o dinheiro investido pelo grupo norte-americano Time Life na consolidação da TV Globo.

A redemocratização do país, a partir de 1985 , encerrou uma ditadura que durou mais de duas décadas, limitando o papel dos militares às suas funções

${ }^{62}$ Disponível em https://www.youtube.com/watch?v=PiV-i-fcxHw, acessado em 09/04/2015 
previstas na Constituição. De lá para cá, mesmo supostamente despojado de sua condição de principal interlocutor das forças conservadoras do País, o Grupo Globo cresceu de forma exponencial, ampliou seus interesses econômicos e garantiu sua posição de maior conglomerado de mídia da América Latina e um dos maiores do mundo.

Durante os setenta e dois anos (de 1931 a 2003) em que esteve à frente, primeiro do $O$ Globo, e depois das demais empresas integrantes do conglomerado que viria a se constituir no Grupo Globo, Roberto Marinho frequentou, assiduamente, os círculos do poder, sempre de forma discreta, mas eficiente, do ponto de vista de seus interesses empresariais.

Mas o que surpreende mesmo, quando investigamos a sua participação em momentos importantes de nossa história recente, é descobrir alguns traços de sua personalidade que não se encaixam naquilo que se espera de alguém tão ligado às forças conservadoras, como por exemplo, sua amizade com D. Hélder Câmara, uma das figuras mais emblemáticas da oposição aos regimes de força no Brasil.

Mais do que amigos, Marinho e D. Hélder eram compadres. Jogavam sinuca e mantinham uma estreita relação.

A sinuca foi outro esporte praticado por Roberto, mas clandestinamente - e
com que parceiro! Ele e D. Hélder Câmara, o grande D. Hélder, eram muito
amigos, e D. Hélder, anos depois, seria o padrinho de José Roberto, o filho
mais moço de Roberto. [...] contava que muitas vezes D. Hélder foi
encontrar-se com ele para almoçarem, mas isso depois de uma ou várias
partidas de sinuca (BRAGA, 2005:21).

Ou ao defender da perseguição dos militares os jornalistas de esquerda que para ele trabalhavam. "Dos meus comunistas cuido eu", foi a resposta que Marinho teria dado ao então Ministro da Justiça Juracy Magalhães, durante o governo militar do general Castello Branco, ao ser questionado sobre os diversos jornalistas simpatizantes do comunismo na redação de $O$ Globo. ${ }^{63}$

63 Esse episódio é relatado por João Roberto Marinho, filho de Roberto Marinho, no documentário "Roberto Marinho: o senhor do seu tempo", Disponível em https://www.youtube.com/watch?v=MqZWL5WcEYQ, acessado em 09/04/2015. 
Há, ainda, outro episódio em que, contrariado pelo regime militar, que havia proibido a exibição de uma novela do horário nobre (Roque Santeiro ${ }^{64}$ ) no dia em que o programa deveria estrear, Roberto Marinho teria escrito um editorial lido na edição daquela noite do Jornal Nacional, da TV Globo, em que, pela primeira vez, admitia a existência da censura no país.

O fato é narrado pelo ex-vice-presidente de operações da TV Globo, José Bonifácio de Oliveira Sobrinho (o Boni) em depoimento a Dermeval Netto:

Pela primeira vez, a Globo teve a coragem de denunciar que no Brasil
existia censura. Que a censura existia e que os jornais não publicavam
nada. Tinha problema de alguns jornais, como O Estado de São Paulo, que
saía com a matéria em branco. Mas um editorial contra a censura não havia
sido publicado ainda, mesmo porque a censura não deixava sair. Então, a
censura foi surpreendida, como ela nos surpreendeu, com a censura do
Roque Santeiro, ela foi surpreendida com o editorial feito pelo Dr. Roberto,
redigido por ele, dizendo que no Brasil havia censura e que nós estávamos
sob censura. ${ }^{65}$ O império em que viria a se transformar o Grupo Globo começa a se desenhar com a inauguração da Rádio Globo do Rio de Janeiro, em dezembro de 1944. Assim como Chateaubriand, Roberto Marinho percebeu o potencial de crescimento para a radiodifusão no Brasil, que desde o início da década de 1940 experimentava um acelerado processo de urbanização.

A população de cerca de 41 milhões de habitantes começava a migrar do campo para a cidade, principalmente por conta do processo de "repulsão populacional na Região Nordeste, fazendo com que a busca por oportunidades de trabalho nos grandes centros urbanos deslocasse milhões de nordestinos." ${ }^{\prime 66}$

É o próprio Marinho que atribui o sucesso do grupo ao investimento feito na comunicação eletrônica, que teria começado justamente com a Rádio Globo.

${ }^{64}$ Em 1975, a censura do Departamento de Polícia Federal proibiu a exibição de Roque Santeiro . A novela estava programada para ir ao ar no horário nobre da TV Globo. Já tinham sido gravados cerca de 30 capítulos quando a Censura Federal percebeu que se tratava de uma adaptação do texto teatral, vetado anteriormente, $O$ Berço do Herói, escrito por Dias Gomes em 1963.

65 Documentário "Roberto Marinho: o senhor do seu tempo", Disponível em https://www.youtube.com/watch?v=MqZWL5WcEYQ, acessado em 09/04/2015.

66 Instituto Brasileiro de Geografia e Estatística - IBGE. Tendências demográficas no período de 1940/2000. Uma análise da população com base nos dados dos Censos Demográficos de 1940 e 2000. Disponível em http://www.ibge.gov.br/home/estatistica/populacao/tendencia demografica/analise populacao/1940 2000/c omentarios.pdf, acessado em 29/04/2015 
Naquela época, início da década de 30, não se podia falar em Organizações Globo nem supor que viessem a existir. Essa história esperaria até 1944 para dar seu primeiro passo fora do âmbito da comunicação impressa, quando decidi fundar a Rádio Globo do Rio de Janeiro, num momento em que o rádio ganhava importância graças aos noticiários sobre a Segunda Guerra Mundial. ${ }^{67}$

Mas o rápido crescimento da empresa de Roberto Marinho no final dos anos de 1930 pode ser explicado, também, pelo estrondoso sucesso obtido com a publicação de gibis e histórias em quadrinhos, que se transformaram em verdadeira mania no Rio de Janeiro, o que geraria os recursos necessários para levar ao ar a Rádio Globo.

A televisão já era um anseio no início dos anos 1950. Tão logo os Diários Associados puseram no ar a sua TV Tupi, em setembro de 1950, Roberto Marinho começa a se movimentar no sentido de conseguir a concessão de um canal de televisão. O general Dutra, presidente da República - e de quem Marinho se tornara muito próximo ${ }^{68}$, teria autorizado a concessão antes de deixar o governo, em janeiro de 1951.

Com o retorno de Vargas ao poder, eleito pelo voto popular para substituir Dutra, a concessão foi revogada. Marinho e Vargas há muito não se entendiam e o antigo caudilho não perdeu a chance de prejudicar o desafeto, tirando-lhe a concessão que nem chegara a ser utilizada.

Somente em 1957, já no governo de Juscelino Kubitschek, Marinho finalmente obtém a concessão para operar um canal de televisão no Rio de Janeiro. Mas, foram necessários oito anos até que o empresário se sentisse seguro para finalmente investir no novo meio de comunicação eletrônica, que já suplantara o rádio na preferência popular.

A TV Globo, canal 4, vai ao ar no dia 26 de abril de 1965 com a difícil missão de enfrentar a poderosa TV Tupi e a inovadora TV Excelsior, líderes de audiência,

67 MARINHO, Roberto. Disponível em http://www.centralcomunicacao.com.br/Revistas/Globo/globo.htm, acessado em 29/04/2015

${ }^{68}$ A aproximação entre Marinho e Dutra se deu durante a Segunda Guerra Mundial, quando O Globo lançou um suplemento especialmente dedicado à Força Expedicionária Brasileira, que lutava na Itália: $O$ Globo Expedicionário. 
na luta pela preferência dos cariocas. Mas Marinho soube tirar proveito do sucesso de suas outras empresas em benefício de seu novo veículo.

Seu jornal estava entre os mais vendidos na cidade e a rádio era líder de audiência. A TV Globo se firmou rapidamente por três razões: um acordo financeiro e operacional com o grupo norte-americano Time-Life, a colaboração com o regime militar e o declínio das TVs Tupi e Excelsior. ${ }^{69}$

A parceria firmada com o grupo editorial norte-americano Time-Life, ainda em 1962, iria se constituir num dos maiores problemas com que Marinho se defrontaria ao longo de sua vida empresarial.

Os 25 milhões de dólares investidos pelos americanos na TV Globo deram origem a uma campanha movida por seus concorrentes, entre eles o implacável Assis Chateaubriand, que por meio de seus contatos e colaboradores, conseguiu que a Câmara dos Deputados instalasse uma Comissão Parlamentar de Inquérito (CPI) para investigar o caso.

A denúncia alegava que a relação com a empresa americana violava o previsto no Art. 160 da Constituição de 1946, que proibia a participação acionária de estrangeiros em empresas de comunicação no Brasil.

Segundo Sodré (1999), o caso Globo/Time-Life ampliava uma discussão que havia se instalado no Brasil desde a década de 1950, quando começaram a surgir denúncias a respeito dos investimentos estrangeiros na imprensa do país. No início, foram levantadas questões que apontavam para uma dependência cada vez maior de nossos veículos em relação à publicidade paga, majoritariamente, por empresas estrangeiras representadas por agências de publicidade, também estrangeiras.

(...) a esmagadora maioria dessas firmas era estrangeira, como estrangeiras eram as agências de publicidade que canalizavam para jornais, revistas, emissoras de rádio e de televisão essas enormes quantias, e que essa canalização obedecia a uma política e, pelo seu vulto e origem, como pelos processos, era, praticamente, o sistema de financiamento das empresas de jornais, revistas, emissoras de rádio e televisão, porque as mantinha e lhes permitia realizar lucros, logo, as condicionava (SODRÉ, 1999: 405/406).

69 Roberto Marinho influiu durante sete décadas. Folha de São Paulo, 07 de agosto de 2003. Disponível em http://www1.folha.uol.com.br/folha/brasil/ult96u52057.shtml, acessado em 29/04/2015 
Portanto, a relação da TV Globo com o grupo norte-americano significava um aprofundamento, uma espécie de sofisticação, de algo que já ocorria ao arrepio da Lei e envolvia praticamente todos os grandes veículos de comunicação da época.

Para os nacionalistas e para os grupos políticos mais à esquerda, isso representava uma ameaça à pluralidade de pensamento, uma vez que "tornava-se cada vez mais difícil lançar jornal novo. (...) só grandes capitais poderiam montar grandes empresas, como os jornais" (Ibidem:393).

A discussão ganhou força através das campanhas conduzidas pelo jornalista e político Carlos Lacerda (antigo aliado transformado em implacável inimigo de Marinho e proprietário do jornal Tribuna da Imprensa) e pelo deputado João Calmon, representante dos Diários Associados de Chateaubriand e presidente da Associação Brasileira das Emissoras de Rádio e Televisão (ABERT).

Pressionado, o presidente Castelo Branco nomeou uma comissão do Ministério da Justiça para apurar as denúncias de que a imprensa estava sendo financiada por empresas estrangeiras, com interesse especial no caso do acordo da TV Globo com a Time-Life.

Os proprietários de jornais, que viam no avanço estrangeiro uma ameaça aos seus negócios, trataram de aproveitar a oportunidade e lançaram um manifesto denunciando "a infiltração de capitais estrangeiros na indústria jornalística nacional, bem como na exploração das concessões de rádio e televisão" e pediam que as restrições legais à participação de capitais estrangeiros no controle acionário das empresas de comunicação fossem respeitadas (HERZ, 2009:176).

Em 22 de agosto de 1966, a Comissão Parlamentar de Inquérito da Câmara dos Deputados conclui que os contratos firmados entre a TV Globo e a Time-Life feriam o artigo 160 da Constituição, então em vigor, e recomendava ao Poder Executivo que a empresa fosse punida.

A CPI determina, ainda, a criação de "uma Comissão Especial interpartidária, para elaborar legislação específica sobre televisão (incluindo-se, também, rádio e 
jornal), para preservar a sua nacionalização, dada à presença de capitais estrangeiros nas organizações que exploram essa atividade."70

Roberto Marinho só viria a se manifestar publicamente sobre o caso cinco anos depois. Em editorial na edição de 08/07/1971 de $O$ Globo, ele alega que os recursos necessários à instalação de emissora de televisão eram enormes e que só recorreu ao financiamento externo porque "a espiral inflacionária já começava sua subida alarmante, o que afastava a hipótese de empréstimos internos a longo prazo." $^{\text {p1 }}$

Marinho afirma ainda, no editorial, que o assunto havia sido levado ao conhecimento do Presidente da República e que este encaminhou a questão à avaliação do Consultor-Geral da República, o qual se manifestou de forma favorável à TV Globo.

Por fim, garante que desfez os acordos com o grupo norte-americano, mesmo ciente de que não havia nenhuma ilegalidade nesses arranjos, assumindo todos os direitos patrimoniais e ressarcindo os norte-americanos dos investimentos feitos.

E conclui, destacando a liderança nacional da TV Globo, "que leva diariamente aos seus milhões de ouvintes imagem e som, realizando valiosa obra de divulgação de informação e cultura, como de entretenimento."

No início dos anos 1970, a TV Globo alcança a liderança inequívoca do mercado midiático brasileiro, se torna a "joia da coroa" e impulsiona o crescimento das demais empresas do grupo. A presença da marca se espalha por diversos setores da atividade econômica, com forte atuação desde o mercado musical, passando pelo setor de serviços e destacando-se na atividade financeira.

As empresas que então compunham as Organizações Globo se multiplicam, acompanhando o ritmo frenético do "milagre brasileiro", embaladas pela capacidade técnica e pela expertise que desenvolvem nas suas respectivas áreas, e pelo olhar aguçado de seu condottiere.

\footnotetext{
${ }^{70}$ Diário do Congresso Nacional, Seção I, Suplemento (B) ao № 6, de 12 de janeiro de 1967, pág. 6

${ }^{71}$ Ver Anexo 4
} 
Apoiado no poder de mobilização de suas emissoras, jornais e revistas, e na força econômica das demais empresas do grupo, Marinho assume a condição de interlocutor privilegiado do regime militar, o que lhe garantiria ainda mais poder, mas também faria dele uma figura demonizada, a expressão viva daquilo que a ditadura militar tinha de pior. 


\section{CAPÍTULO V - A TRANSIÇÃO SE COMPLETA OU NÃO}

Quando nos dispusemos a estudar a transição do jornalismo partidário para o jornalismo de informação, tendo como referência as mudanças estruturais que se sucedem ao longo da história do nosso jornalismo, tínhamos consciência de que, para que essa pesquisa alcançasse seus objetivos seria necessário construir um dispositivo analítico que contemplasse a diversidade e a subjetividade dos fenômenos dos quais buscávamos nos aproximar. A partir daí, nos vimos diante da necessidade de apontar o que consideramos "mudança estrutural" e como esse conceito se aplica à pesquisa histórica do jornalismo.

Ao estabelecer, ainda na introdução, as ferramentas metodológicas que nos permitiriam chegar a tal dispositivo, antecipamos nossa intenção de lançar mão de um modelo baseado em pressupostos teóricos de diferentes campos do conhecimento e que servem aos estudos dos fenômenos sociais.

Dentre esses, apontamos o conceito de tipo ideal weberiano como uma possibilidade, pois tal opção nos permitiria atribuir um tratamento científico aos fenômenos históricos que tentávamos compreender, destacando-Ihes tipicidade e homogeneidade.

O modelo weberiano de tipo ideal ressalta aspectos comparativos que nos garantem a possibilidade de observar e criar hipóteses sobre a realidade analisada.

Obtém-se um tipo ideal mediante a acentuação unilateral de um ou de
vários pontos de vista e mediamente o encadeamento de grande
quantidade de fenômenos isoladamente dados, difusos e discretos, que se
podem dar em maior ou menor número ou mesmo faltar por completo, e que
se ordenam segundo os pontos de vista unilateralmente acentuados, a fim
de se formar um quadro homogêneo de pensamento (WEBER,
1973:137/138).

O próprio Weber chama a atenção para o fato de que é impossível identificar na realidade um quadro como esse, com tamanha pureza conceitual, o que seria, segundo ele, uma utopia. Mas reafirma sua crença na validade do tipo ideal como 
uma tentativa de apreender os fenômenos históricos a partir de ações sociais que podemos identificar nesses fenômenos.

E prossegue, identificando na ação humana quatro tipos de ação social passíveis de serem eleitas como tipos ideais: a ação racional no tocante aos fins; a ação racional com relação a um valor; a ação afetiva; e a ação tradicional, devendo o pesquisador concentrar-se na tentativa de captar empiricamente o sentido que os agentes buscam emprestar às suas ações.

Além de envolver a percepção da intenção dos agentes presentes em determinado fenômeno na construção de uma tipologia ideal, Weber acrescenta outro elemento que precisa ser considerado nesse processo: o tipo de dominação presente nas relações entre os diversos agentes.

E ele classifica a dominação como sendo a capacidade que determinados agentes têm de influenciar a conduta de outros, influência que se materializa sob a forma de submissão do dominado à vontade do dominador. Nesse sentido, Weber identifica três motivos para que a obediência se manifeste nos dominados: por tradição; pelo carisma; ou por meio de um instrumento legal.

Tendo chegado à conclusão de que o caminho apontado por Weber era perfeitamente adequado ao trabalho de análise que tínhamos pela frente, tratamos de construir um conjunto de tipos ideais que nos permitiu analisar e compreender de que forma se deu a transição do jornalismo partidário para o jornalismo de informação no Brasil, configurando, assim, uma importante mudança estrutural no nosso jornalismo ${ }^{72}$.

Para construir esse conjunto de tipos, partimos do pressuposto de que poderíamos identificar as mudanças em elementos que, historicamente, permaneceram presentes nos dois modelos de jornalismo aqui estudados: o jornalismo partidário e o jornalismo de informação.

72 Charron e Bonville (2004) definem quatro tipos de jornalismo a partir do tipo de sociedade em que se acham inseridos: jornalismo de transmissão, jornalismo de opinião, jornalismo de informação e jornalismo de comunicação. Cada um desses tipos reúne elementos paradigmáticos suficientemente distintos para que possamos afirmar que a transição entre eles constitui-se numa mudança estrutural. 
Sendo assim, definimos que na tipificação das ações sociais relacionadas à transição entre os dois modelos de jornalismo consideraríamos como tipo ideal os seguintes aspectos presentes na atividade jornalística: a empresa, o jornalista, o discurso jornalístico e a ação empresarial.

Antes de avançarmos no sentido de identificar a existência e o impacto dessas mudanças, nos parece indispensável revisitar as questões que envolvem o conceito de mudança estrutural e de como podemos identificá-las por meio da construção de tipos ideais.

O jornalismo, visto como prática social é algo em permanente transformação, graças ao dinamismo dos agentes envolvidos nessa prática e à complexidade do ambiente em que ela ocorre, onde estão inseridas pessoas e instituições, submetidas à normatização e à regulação, além de intervenções promovidas por entes econômicos e políticos ali presentes.

Sendo assim, podemos dizer que o jornalismo, na condição de prática social, é marcado por um processo de reinvenção permanente, o que favorece a mudança. Por isso, dependendo do alcance e das consequências provocadas por tais mudanças, podemos definir novas configurações para o jornalismo, o que viria se constituir numa mudança de caráter estrutural.

Para que uma mudança seja considerada estrutural é preciso, portanto, que
ela seja suficientemente abrangente e profunda para alterar radicalmente o
modo como determinada atividade é praticada e simbolicamente
reconhecida/definida pelos atores. Ou seja, uma mudança estrutural se
contrapõe a um grupo de mudanças conjunturais e também às
microinovações que normalmente afetam aspectos específicos de uma
prática social (PEREIRA et ADGHIRNI, 2011:42).

E esses autores acrescentam que tais transformações estruturais estariam presentes nos aspectos ligados à produção da notícia, ao perfil do profissional da área e às relações que os veículos mantêm com os públicos.

Nesse caso, a identificação de ações sociais nitidamente tipificadas a partir desses aspectos, e que não venham a se constituir em simples alterações de caráter conjuntural, nos permitiu apontar, com relativa segurança, a ocorrência de uma mudança estrutural. Daí, nossa opção por construir um dispositivo de análise que 
contemplasse os seguintes tipos ideais relacionados com o fenômeno que estudamos e tendo como referência:

5.1 As empresas jornalísticas brasileiras nesse período de transição (final do século XIX e início do século $X X)$, tipificando-as a partir das seguintes características: estrutura administrativa, fonte de financiamento e relações políticopartidárias.

5.2 O profissional do jornalismo daquele período, tipificado a partir de sua origem, formação, rotinas produtivas e reconhecimento social.

5.3 A construção do discurso jornalístico: pauta, estilo e utilização de recursos gráficos.

5.4 A ação empresarial dos proprietários de empresas jornalísticas: empreendedor tradicional (capitão-de-indústria) e o homem de empresa.

$\mathrm{Na}$ definição das características desses empreendedores utilizamos como referência a descrição feita por Cardoso $(1964)^{73}$, citada por Fonseca (2005:120/121) e que reproduzimos a seguir:

5.4.1 Empreendedor Tradicional (Capitão-de-indústria) - "Movido pelo espírito da usura mais que pela poupança metódica e exploração racional da força de trabalho. Teria uma compreensão muito limitada dos problemas e orientar-se-ia no sentido de manipular fatores que propiciassem acumulação fácil e rápida de capitais".

Esse tipo de empreendedor paga baixos salários e valoriza o trabalho pesado. Cardoso conclui, dizendo que essa postura não permitiria ao país superar sua condição de economia pré-capitalista.

${ }^{73}$ No trabalho referenciado (Empresário industrial e o desenvolvimento econômico. São Paulo. Difusão Europeia do Livro, 1964), Fernando Henrique Cardoso investigou a participação de empreendedores industriais no desenvolvimento econômico do Brasil, a partir do que ele chamou de "mentalidade empresarial". Essa análise foi utilizada por Virgínia Pradelina da Silveira Fonseca para compreender a organização da empresa jornalística no período anterior ao das indústrias culturais. 
5.4.2 Homem de empresa - "Alia o grau de compreensão do seu papel como industrial à prática de medidas visando baratear e melhorar a produção em massa, de forma a enfrentar as novas condições do mercado e da concorrência".

Esse tipo atua, também, fora da empresa, incentivando ideias e iniciativas que, indiretamente, beneficiem a indústria como um todo. Preocupa-se com a reorganização técnica e com o aumento da produtividade. Não tem obsessão pelo lucro rápido e busca ampliar a produção com base na tecnologia.

A tabela a seguir (Tabela 2) registra os tipos ideais com que nos deparamos ao analisar as empresas jornalísticas, os jornalistas, o discurso jornalístico e a ações empresariais predominantes durante o período de transição do jornalismo partidário para o jornalismo de informação no Brasil.

Para construir os diferentes tipos, levamos em consideração aspectos relacionados à ação social de cada um deles, descritas ou analisadas ao longo dos capítulos precedentes, nos quais se buscou recuperar parte da história do jornalismo brasileiro a partir de uma extensa pesquisa bibliográfica e documental. 
5.5 TIPIFICAÇÃO DAS AÇÕES SOCIAIS PRESENTES NA ATIVIDADE JORNALÍSTICA DURANTE A TRANSIÇÃO DO JORNALISMO PARTIDÁRIO PARA O JORNALISMO DE INFORMAÇÃO - TABELA 2

\begin{tabular}{|c|c|c|c|}
\hline \multirow{2}{*}{ TIPO IDEAL } & \multirow{2}{*}{$\begin{array}{l}\text { CARACTERÍSTICA } \\
\text { TIPIFICADA }\end{array}$} & \multicolumn{2}{|c|}{$\begin{array}{c}\text { AÇÕES SOCIAIS QUE CARACTERIZAM } \\
\text { O TIPO IDEAL }\end{array}$} \\
\hline & & $\begin{array}{l}\text { JORNALISMO } \\
\text { PARTIDÁRIO }\end{array}$ & $\begin{array}{l}\text { JORNALISMO } \\
\text { INFORMATIVO }\end{array}$ \\
\hline \multirow{3}{*}{$\begin{array}{l}\text { EMPRESA } \\
\text { JORNALÍSTICA }\end{array}$} & $\begin{array}{c}\text { Estrutura } \\
\text { Administrativa }\end{array}$ & $\begin{array}{l}\text { Incipiente } \\
\text { Número reduzido } \\
\text { de funcionários } \\
\text { Alto nível de } \\
\text { informalidade }\end{array}$ & $\begin{array}{c}\text { Bem definida } \\
\text { Número maior de } \\
\text { funcionários } \\
\text { Formalidade acentuada }\end{array}$ \\
\hline & $\begin{array}{l}\text { Fonte de } \\
\text { Financiamento }\end{array}$ & $\begin{array}{l}\text { Partidos políticos } \\
\text { Grupos de } \\
\text { interesse } \\
\text { Governos em } \\
\text { seus diferentes } \\
\text { níveis }\end{array}$ & $\begin{array}{c}\text { Comercialização em banca } \\
\text { Comercialização de espaço } \\
\text { publicitário } \\
\text { Agentes financeiros } \\
\text { públicos e privados }\end{array}$ \\
\hline & $\begin{array}{l}\text { Relações Político- } \\
\text { partidárias }\end{array}$ & $\begin{array}{l}\text { Intensas e } \\
\text { explícitas }\end{array}$ & $\begin{array}{l}\text { Eventuais } \\
\text { Dissimuladas }\end{array}$ \\
\hline \multirow{4}{*}{ JORNALISTA } & Origem & Elite & $\begin{array}{c}\text { Elite } \\
\text { Classes intermediárias }\end{array}$ \\
\hline & Formação & $\begin{array}{l}\text { Bacharéis, } \\
\text { Literatos }\end{array}$ & $\begin{array}{l}\text { Bacharéis } \\
\text { Jornalistas }\end{array}$ \\
\hline & Rotinas & $\begin{array}{l}\text { Interna na } \\
\text { redação }\end{array}$ & $\begin{array}{l}\text { Redação } \\
\text { Boa parte externa }\end{array}$ \\
\hline & $\begin{array}{l}\text { Reconhecimento } \\
\text { social }\end{array}$ & Alto & Baixo \\
\hline \multirow{3}{*}{$\begin{array}{l}\text { DISCURSO } \\
\text { JORNALÍSTICO }\end{array}$} & Pauta & $\begin{array}{l}\text { Predomínio de } \\
\text { assuntos políticos } \\
\text { Pouca variedade }\end{array}$ & $\begin{array}{l}\text { Atualidades, fait divers, } \\
\text { cultura, esportes }\end{array}$ \\
\hline & Estilo & $\begin{array}{l}\text { Sóbrio, literato, } \\
\text { nariz de cera }\end{array}$ & Simples, claro, lead \\
\hline & Recursos gráficos & $\begin{array}{l}\text { Poucos ou } \\
\text { inexpressivos }\end{array}$ & $\begin{array}{l}\text { Ilustrações, fotos, } \\
\text { manchetes, subtítulo } \\
\text { colunas múltiplas, fios }\end{array}$ \\
\hline $\begin{array}{c}\text { AÇĀO } \\
\text { EMPRESARIAL }\end{array}$ & Empreendedor & $\begin{array}{c}\text { Não se } \\
\text { caracteriza }\end{array}$ & $\begin{array}{l}\text { Capitão-de-indústria, } \\
\text { Homem de Empresa }\end{array}$ \\
\hline
\end{tabular}




\subsubsection{A empresa jornalística}

Ao tipificar a empresa jornalística, levamos em conta três aspectos que consideramos perfeitamente capazes de indicar as mudanças estruturais que possam ter ocorrido ao longo do período que estudamos. São elas: a) estrutura administrativa; b) fonte de financiamento; e c) relações político-partidárias.

a) Estrutura Administrativa:

No que tange à estrutura administrativa, observamos que durante o jornalismo partidário essas empresas apresentavam estruturas bastante incipientes. As tarefas e funções eram desempenhadas por um pequeno número de funcionários (parte deles, não remunerados), o que gerava uma estrutura administrativa com alto grau de informalidade.

Como descreve Sodré (1999:159), os jornais eram produtos de uma só pessoa: escritor e político, que servia a seus próprios interesses ou a facções e que seguindo sua própria orientação ou por ordem de outros, escrevia o jornal inteiro.

Em contrapartida, no jornalismo informativo as estruturas empresariais se sofisticam, tornam-se bem definidas. O número de funcionários se amplia e há uma clara divisão de tarefas e departamentalização, o que acentua os aspectos formais da organização jornalística.

Essas mudanças estruturais na organização administrativa dos jornais brasileiros se dão justamente no período em que despontam as primeiras teorias relacionadas ao campo da Administração, o que nos permite inferir que essa nova concepção de organização acabou por influenciar as práticas e modelos de gestão dos jornais brasileiros ainda no início do século XX.

A redação e a administração dos jornais passam a ser conduzidas separadamente. Cresce a preocupação com a profissionalização dos demais setores que compõem as empresas jornalísticas, como a oficina, a contabilidade e a distribuição. Processos e métodos do campo administrativo passam a ser utilizados, com mais frequência, nas atividades de apoio à produção jornalística. 
b) Fontes de Financiamento

Os partidos políticos ou grupos de interesse se encarregavam de financiar as empresas jornalísticas durante o jornalismo partidário. Além dessas fontes, os veículos buscavam junto aos governos os recursos financeiros para que se mantivessem ativos. Isso gerava muita insegurança e provocava uma alta taxa de mortalidade desses veículos. Muitos não passavam do primeiro número.

Com a comercialização em banca, a venda de espaços publicitários e a busca de financiamento junto a agentes financeiros (públicos e privados), a empresa típica do jornalismo informativo ganha mais autonomia e capacidade de investir em equipamentos e na contratação de profissionais especializados, visando melhorar a qualidade do seu produto e atrair mais leitores.

Transformados em empresa, os cinco diários mais importantes da cidade passam a vender além do matutino ou do vespertino que diariamente imprimem, outros produtos. A partir de 1890 , todos se transformam em verdadeiras editoras, comercializando serviços de impressão a terceiros. Ao lado da tipografia destinada à impressão do jornal existe sempre uma outra: a oficina de obras (BARBOSA, 2000:38).

De qualquer forma, mesmo com fontes de financiamento diversificadas e mais confiáveis, as empresas jornalísticas desse período ainda buscavam recursos junto aos governos.

Durante as primeiras décadas do século $X X$, a instabilidade política $\mathrm{e}$ institucional repercutiu, enormemente, no desenvolvimento econômico do país, o que sem dúvida aumentou as dificuldades de financiamento e capitalização das empresas jornalísticas, tornando-as ainda mais suscetíveis às interferências do poder econômico e do poder político, incluindo a ação do governo por meio de seus agentes financeiros ou de empresas públicas que se tornam grandes anunciantes.

c) Relações Político-partidárias

Naturalmente, no período em que predomina o jornalismo partidário, essas relações se apresentavam intensas e explícitas. Na verdade, as empresas jornalísticas (as que assim se constituíam) eram extensões ou braços operacionais de partidos ou de grupos de interesse político. Não havia, por parte dos jornais, a preocupação em dissimular ou encobrir essa condição de total dependência. 
Era, sobretudo, um jornalismo de causas, com importante participação em momentos decisivos de nossa história política, desde as lutas pela independência, passando pelas campanhas abolicionista e republicana.

Maria Alice Carvalho (CARVALHO, 2012:62) registra que, em 1898, os jornais de oposição política e de orientação monarquista, criticavam sistematicamente o governo republicano de Deodoro da Fonseca. Havia na época, segundo a autora, uma diversidade de orientações políticas na imprensa do Rio de Janeiro.

Já Sodré esclarece que, naquele momento, o fato político, e não a política estava no centro do interesse dos jornais.

\begin{abstract}
A preocupação fundamental dos jornais, nessa época, é o fato político. Note-se: não é a política, mas o fato político. Ora, o fato político ocorre, então, em área restrita, a área ocupada pelos políticos, por aqueles que estão ligados ao problema do poder. Assim, nessa dimensão reduzida, as questões são pessoais, giram em torno de atos, pensamentos ou decisões de indivíduos, os indivíduos que protagonizam o fato político (SODRÉ, 1999:277).
\end{abstract}

Com o surgimento do jornalismo informativo, as relações entre as empresas jornalísticas e os grupos partidários passam a se dar de maneira menos evidente. Apenas em momentos críticos ou de extrema gravidade, os jornais explicitavam suas posições políticas, como durante as tentativas de quebra da ordem constitucional.

Acreditamos que essa mudança nas relações entre o jornalismo e a política partidária está diretamente ligada à maneira como os jornais passam a ser constituídos. São empreendimentos que surgem das afinidades que se estabelecem dentro das redações e que resultam, ainda, da percepção de empresários e de jornalistas de que deviam se manter afastados de subvenções e recursos governamentais, garantindo a sua autonomia, "desde que houvesse anunciantes e que a atividade de seus membros mantivesse a venda unitária em patamar elevado e estável" (CARVALHO, 2012:83).

Apesar de se aproximar da política de uma maneira mais cautelosa, menos ostensiva, o jornalismo, mesmo quando o processo de mudança do modelo partidário para o modelo informativo já se consolidara, jamais abandonou o interesse e o fascínio pelo campo político. 
Longe de se constituir num fator extemporâneo ou secundário, a política afeta decisivamente o funcionamento de todas as facetas da moderna empresa jornalística: da sua organização administrativa ao tamanho e características de seu público; dos seus valores profissionais, às técnicas de impressão utilizadas na sua primeira página - nenhum aspecto dos modernos jornais diários escapa da forte e insidiosa influência da política (KAPLAN, 2002:184)

Para Kaplan (2002), os historiadores da mídia costumam negligenciar essa dimensão política do jornalismo. Esse descaso, de fato, atesta a difusão do ideal profissional que permeia o jornalismo moderno. De acordo com esta imagem cultural, o único dever do verdadeiro jornalismo consiste em garantir informações factuais e confiáveis aos cidadãos. $E$ todos nós sabemos que isso nem sempre é o que acontece.

\subsubsection{O Jornalista}

No que refere ao jornalista, aquele responsável pela construção do discurso jornalístico, identificamos três aspectos que nos permitem avaliar suas ações sociais nos diferentes modelos de jornalismo aqui analisados. São eles:

\section{a) Origem}

No jornalismo partidário, a origem dos jornalistas era predominantemente ligada à elite. Eram figuras destacadas no ambiente político, provenientes, em sua maioria, de famílias ricas, normalmente com interesses na agricultura e desempenhando importantes funções junto à burocracia imperial. Quase todos são advogados por formação.

Por outro lado, os jornalistas que atuaram no jornalismo informativo tinham uma origem mais diversificada, com representantes da elite (a maioria deles atuando como dirigentes nas empresas) e com profissionais oriundos de classes intermediárias, filhos de comerciantes e de funcionários públicos que compunham parte considerável de uma sociedade que se urbanizava rapidamente.

b) Formação

\footnotetext{
${ }^{74}$ Tradução para o português feita pelo autor
} 
No período que antecede ao jornalismo informativo no Brasil não havia $o$ jornalista. Os jornais eram feitos por idealistas, doutrinadores de viés iluminista, que usavam os jornais para defender suas ideias ou simplesmente influir nos acontecimentos políticos.

A formação dos jornalistas do período partidário acompanhava o que acontecia em outros setores da sociedade. A maioria era de bacharéis em Direito. Alguns poucos tinham outra formação superior (médicos e engenheiros). E havia, ainda, um pequeno número de jornalistas oriundos das escolas militares.

Esse tipo de formação dava aos jornalistas uma visão muito particular dos problemas. As divergências eram, em grande parte, em relação a aspectos conjunturais. Na essência, a posição e a visão de mundo eram muito parecidas, independente do posicionamento político dos jornais para os quais escreviam.

Com a imprensa informativa a formação dos jornalistas se altera. Apesar de ainda existir um número considerável de bacharéis, já é possível encontrar profissionais que aprenderam o ofício nas próprias redações (Irineu Marinho e Roberto Marinho são exemplos típicos).

Invariavelmente, a formação desse novo jornalista começava muito cedo. Era preciso ter certa competência linguística para garantir o acesso à corporação. $O$ mais comum era o jovem aspirante à jornalista empregar-se como revisor.

A revisão era uma tarefa que tomava muito tempo e exigia uma quantidade razoável de pessoas, principalmente por conta do processo de composição manual dos textos que gerava muitos erros que precisavam ser corrigidos antes da impressão.

A leitura regular dos textos produzidos pelos jornalistas veteranos dava aos jovens revisores uma familiaridade com as expressões e com os arranjos discursivos utilizados na construção das matérias, o que os credenciava a partir, eles próprios, para a redação das notícias.

E assim se dava a formação dos novos profissionais, acompanhados de perto pelos jornalistas mais experientes, que identificavam e apadrinhavam aqueles que julgavam dotados de vocação e disposição para a profissão. 
A preocupação em oferecer uma formação específica para os jornalistas surge ainda no início do século XX, quando a Associação Brasileira de Imprensa discute a questão e tenta implantar os primeiros cursos de jornalismo, o que só iria ocorrer na década de 1930 na Universidade do Distrito Federal.

Com o predomínio do jornalismo informativo as redações passam a valorizar o trabalho dos jornalistas profissionais, que se dedicam permanentemente à atividade, o que irá exigir competências e habilidades àqueles que se dispunham a atuar na área, reforçando a necessidade de uma formação específica.

c) Rotinas

Quando nos referimos às rotinas, temos em mente as tarefas regularmente desempenhadas pelos jornalistas em suas atividades. No período partidário, essas tarefas eram realizadas quase que totalmente nas redações. Eram os chamados "jornalistas de gabinete". Boa parte do tempo dedicado ao trabalho jornalístico era dispendida em atividades internas, como a leitura e a pesquisa de informações, além do tempo reservado à redação e à revisão dos textos.

Com as mudanças trazidas pela implantação do jornalismo informativo alteram-se, definitivamente, as atividades desempenhadas pelos jornalistas. $O$ trabalho nos jornais deixa de ser um "bico", uma complementação de renda para exigir maior dedicação.

Repórteres, redatores e revisores passam a compor um quadro fixo de funcionários que cumprem uma rotina de trabalho bem delineada, segundo uma lógica administrativa que privilegia a especialização e a divisão racional das tarefas.

Os profissionais passam a exercer atividades específicas de acordo com o setor do jornal em que estão inseridos. Havia os redatores encarregados de acompanhar e redigir as notícias internacionais e nacionais que chegavam em forma de telegramas, enviados pelas agências de notícia sobre acontecimentos no exterior ou em outros estados.

Aos repórteres competia ir às ruas em busca da informação factual, principalmente os crimes e fatos inusitados de interesse da população. Passavam boa parte do dia percorrendo delegacias, hospitais, cemitérios, além de manter 
contato com os serviços públicos essenciais à vida do cidadão (transportes, energia e abastecimento de água). Ao final da tarde, retornavam às redações onde repassavam os dados e informações recolhidas ao longo do dia aos redatores.

d) Reconhecimento Social

Por se tratar de atividade conduzida especificamente pela elite, o reconhecimento social de que gozavam os jornalistas durante o período partidário era alto. Esse prestígio estava relacionado, principalmente, à posição social daqueles que exerciam o jornalismo: oriundos da aristocracia, membros da alta administração pública e dos partidos, integrantes da Maçonaria e das Ordens e Irmandades católicas.

Tinham ainda em comum a educação formal: advogados, médicos, engenheiros, padres e militares, dotados de uma certa erudição e de visões muito particulares dos problemas que afligiam o país e seus concidadãos. E eram lidos, majoritariamente, por comerciantes, clérigos, militares, médicos, cirurgiões, senadores, deputados e funcionários públicos. Daí decorria o grande prestígio que gozavam os jornalistas dessa fase.

A profissionalização da atividade jornalística, já no período do jornalismo informativo, abriu as portas das redações a pessoas oriundas dos segmentos intermediários da sociedade. São, na maioria, jovens estudantes que buscam no jornalismo uma forma de ganhar algum dinheiro ou prestígio para conseguir um cargo público.

A atividade paga muito mal e esses novos jornalistas acabam por desenvolver hábitos e comportamentos que os distingue socialmente. Frequentam ambientes comuns e, a pretexto de obter informações e notícias, transitam com desenvoltura pelos submundos da boemia e da marginalidade.

Com a proliferação de repórteres, cresceram em número e importância os chamados "cafés em pé" - na verdade, balcões onde a infusão era infinitamente mais valorizada do que nos ambientes em que "café" se tornara apenas a senha para a reunião de boêmios em torno de uma mesa. Isso significa que a profissionalização de jovens jornalistas alterou, progressivamente, a relação do estrato de intelectuais com o espaço urbano (CARVALHO, 2012:50). 
Assim, não é difícil entender porque a profissão perde prestígio social, apesar da importância cada vez maior da atividade jornalística para uma sociedade que se urbanizava e crescia rapidamente.

\subsubsection{O Discurso Jornalístico}

Dentre as diversas mudanças observadas na transição do jornalismo partidário para o jornalismo informativo, destacamos como uma das mais importantes as que se referem à construção do discurso jornalístico, aqui entendido como sendo um processo social de construção da realidade, delimitado por um conjunto de regras que envolvem a relação do discurso com o fato e por convenções narrativas específicas do campo jornalístico.

As diferenças significativas entre o discurso produzido durante o período partidário e o discurso do jornalismo informativo podem ser identificadas a partir da análise dos elementos que delimitam tal (re)construção da realidade, e que vão desde a escolha dos assuntos apontados como sendo os de interesse comum - a pauta; passando pelos recursos linguísticos utilizados na organização da narrativa o estilo; até chegar aos elementos não verbais que contribuem para ampliar a compreensão a respeito dos fatos e da realidade ali discutidos - os recursos gráficos.

\section{a) Pauta}

No jornalismo partidário, a escolha dos assuntos a serem destacados pelos veículos privilegiava os temas passíveis de serem discutidos de um ponto de vista doutrinário e que permitiam a construção de discursos dotados de características que variavam da proposição à polêmica, passando pelo resgate históricoepistemológico.

Com isso, os artigos resultantes desse tipo de escolha tinham por objetivo discutir, duvidar, analisar e combater.

Ora, o que mais se fazia, naquela fase, era precisamente discutir, pôr em dúvida, analisar, combater. Combater a pretensa sacralidade das instituições: da escravidão, da monarquia, do latifúndio. E a imprensa tinha, realmente, em suas fileiras, grandes combatentes, figuras exemplares, como homens de jornal e como homens de inteligência ou de cultura (SODRÉ, 1999:233). 
As mudanças estruturais que demarcam o início do jornalismo informativo farão com que os assuntos e os temas transformados em discurso jornalístico saiam do campo doutrinário e ingressem na realidade imediata dos leitores.

As intermináveis polêmicas, as análises inconclusivas e 0 apelo à historicidade dos fatos dão lugar aos problemas do dia a dia, às questões que interferem concretamente na qualidade de vida dos leitores e na prestação de serviços essenciais numa sociedade cada vez mais complexa.

b) Estilo

Quando analisamos os recursos linguísticos que caracterizam o jornalismo partidário e os que vamos encontrar logo adiante, no jornalismo informativo, identificamos diferenças essenciais que marcaram o discurso jornalístico nessas diferentes fases da história do jornalismo brasileiro.

Os jornais partidários utilizavam-se de um vocabulário rebuscado, pseudoliterário e pretensiosamente erudito. Era recorrente o uso de figuras de linguagem como a metáfora, a hipérbole, a metonímia e a ironia na tentativa de dotar os textos de uma maior expressividade.

O noticiário era redigido de forma difícil, empolada. O jornalismo feito ainda
por literatos é confundido com literatura, e no pior sentido. As chamadas
informações sociais - aniversários, casamentos, festas - aparecem em
linguagem melosa e misturam-se com a correspondência de namorados
(Ibidem:283).

$\mathrm{Na}$ batalha pela ampliação do número de leitores, uma das armas utilizadas pela imprensa informativa foi a simplificação da linguagem utilizada na construção de seu discurso jornalístico. O jornal devia ser lido e compreendido por todos. A escolha das palavras obedecia a um critério que tinha na simplicidade sua característica mais importante.

A referência eram os termos usados pela maioria da população em suas relações cotidianas. Dessa forma, o homem comum, o funcionário público, o empregado do comércio e o operário percebiam como os personagens e acontecimentos retratados eram próximos de suas realidades. 
A influência norte-americana e a objetividade comumente encontrada nos textos das agências de notícias transformam o discurso jornalístico, tornando-o mais claro, simples e direto, estilo que irá se impor, definitivamente, com a introdução do lead, já na metade do século XX.

c) Recursos Gráficos

Falta de movimento, colunas alinhadas, ausência de subtítulos e manchetes, títulos curtos que não destacavam os principais elementos das notícias. Invariavelmente, os jornais do período partidário tinham essas características gráficas.

Os recursos visuais (ilustrações, desenhos, diagramas) eram praticamente inexistentes, o que deixava os jornais com um aspecto bastante homogêneo. Era quase impossível encontrar elementos gráficos que os distinguissem. Por isso o recurso ao dístico, impresso logo abaixo do título do jornal, normalmente tomado a uma obra clássica, usado para identificar o jornal com algum grupo ou ideia política.

Outro fato que tornava os jornais mais "pesados" e de difícil leitura era a diagramação, fazendo com que o leitor tivesse dificuldade em encontrar a continuação de um texto que se iniciava na primeira página e depois desaparecia, sendo encontrado no rodapé da última página.

As mudanças estruturais nesse aspecto começam com o desenvolvimento de novas técnicas e equipamentos para a impressão. São importadas impressoras mais modernas, capazes de imprimir um número maior de exemplares por hora, movidas, inicialmente, a vapor e, logo depois, a eletricidade. Além disso, o processo de composição a quente, com a introdução da linotipia, torna todo o trabalho de composição das páginas mais rápido e dinâmico.

Enquanto as novas tecnologias de impressão - incluindo as rotativas aceleram o ritmo de produção e melhoram a qualidade gráfica das publicações, a fotografia ganha um lugar de destaque nas páginas dos jornais, ampliando o impacto da informação (FREIRE, 2009:297). 


\subsubsection{O Empreendedor}

O típico jornal partidário não chegava a se constituir num empreendimento. A atividade desenvolvida por aqueles que criavam e mantinham esses veículos tinha um caráter quase que messiânico. Não havia nenhuma expectativa de que o jornal viesse a dar lucro, ou pelo menos arrecadar o suficiente para cobrir os custos de impressão e circulação.

Portanto, nessa fase do jornalismo brasileiro inexistia a figura do empreendedor. Os que se lançavam à aventura de publicar um jornal buscavam, antes de tudo, prestígio para defender interesses próprios ou dos grupos aos quais pertenciam.

As mudanças econômicas, sociais e políticas ocorridas no país a partir da segunda metade do século XIX já apontavam que o modelo de jornalismo que tinha na atividade político-partidária sua principal fonte de sustentação econômica finalmente se esgotara. Já há algum tempo os jornais vinham se transformando em empreendimentos que buscavam garantir retorno financeiro aos seus investidores.

Fazer jornal tornou-se uma atividade cara e que demandava planejamento e estratégias que garantissem sucesso ao negócio. Era preciso ampliar, cada vez mais, o número de leitores, diluindo custos e aumentando o lucro. A notícia transformara-se em mercadoria que precisava ser comercializada com inteligência e dinamismo.

O investidor, o dono, o proprietário, torna-se figura importante do universo jornalístico e que busca manter a atividade lucrativa. A independência editorial tornase estratégica e a lealdade de seus leitores, o objetivo.

Foi possível identificar, a partir dos dados levantados nesta pesquisa, a existência de dois tipos distintos de empreendedores no segmento das empresas jornalísticas já no período em que se consolidam as mudanças que irão caracterizar o jornalismo informativo.

O primeiro tipo, também chamado de empreendedor tradicional - e que CARDOSO (1964), denomina "capitão-de-indústria" - tem como característica marcante a preocupação com o retorno rápido do capital investido. Para isso, não 
mede esforços na implantação de um modelo administrativo que privilegia a exploração da mão de obra e o uso intensivo dos recursos disponíveis. Sua compreensão e capacidade de solucionar os problemas são limitadas por seus interesses imediatos, retardando, ou mesmo impedindo, o crescimento da empresa.

Contrastando com esse tipo de empreendedor, o jornalismo brasileiro se beneficiou da ação de empresários capazes de implantar nos seus veículos um modelo de gerenciamento que privilegiava os investimentos de longo prazo, capazes de garantir maior solidez ao negócio, encontrando soluções criativas para enfrentar as dificuldades estruturais que atrapalhavam o desenvolvimento da atividade jornalística no país.

Foram esses empreendedores - chamados de "Homens de Empresa" - que estabeleceram as condições essenciais que levaram à construção dos conglomerados midiáticos brasileiros, ao investirem na formação de um público leitor e no fortalecimento do jornalismo como elemento essencial ao desenvolvimento econômico, político e social do Brasil.

\subsection{CONSEQUÊNCIAS DESSAS MUDANÇAS}

Tendo caracterizado a existência de mudanças estruturais que nos permitem assinalar a ocorrência de uma transição do jornalismo partidário para o jornalismo informativo, que se inicia, timidamente, nas últimas décadas do século XIX e avança até o século $\mathrm{XX}$, nos resta identificar que consequências esse fato trouxe para 0 jornalismo brasileiro.

Antes, porém, cabe uma ressalva importante, no que se refere ao alcance de mudanças dessa natureza, principalmente com respeito ao momento em que um novo paradigma emerge e se consolida.

A percepção de que uma nova ordem estrutural se impõe, caracterizando a transição entre diferentes modelos, não se dá num momento específico, claramente demarcado no tempo. Pelo contrário, haverá sempre a coexistência temporária de modelos díspares, até que um deles finalmente prevaleça.

Agilidade, nova linguagem e profissionalização atestam a renovação da imprensa carioca, embora coisa nenhuma nessa transição tenha sido feita rapidamente. Por algum tempo conviverão os boêmios e os novos quadros 
do jornalismo profissionalizado; os longos artigos de opinião e as reportagens. Lentos foram também o crescimento do público e a substituição das tecnologias de composição e impressão até então adotadas (CARVALHO, 2012:51).

Sodré reforça esse entendimento ao distinguir na trajetória histórica da imprensa brasileira diferentes arranjos estruturais, os quais ele chamou de "fases", que se iniciam com a "imprensa colonial", seguida pelas fases da "imprensa da independência", da "imprensa do império" até chegar à fase que ele denomina de "a grande imprensa".

E conclui lembrando que as diferenças que se observam entre esses modelos se dão de forma progressiva e que as proporções que assumem variam com o tempo e o meio (SODRÉ, 1999:XIII).

A consolidação do jornalismo informativo no Brasil trouxe consequências importantes para as empresas, para os profissionais, para o discurso jornalístico e para as questões relacionadas à propriedade dos meios de comunicação. E todas essas mudanças vão, sem dúvida, repercutir nas relações que o jornalismo passa a manter com os públicos.

Vale lembrar que nem todos os jornais que ainda circulavam no período em que o jornalismo informativo se consolida conseguiram completar a transição. Muitos ficaram pelo caminho. E essa é a primeira das consequências trazidas pelo novo paradigma: a drástica redução no número de jornais em circulação.

Esse fenômeno teria concorrido para dar início a um processo de concentração, no qual se reduziu, consideravelmente, o número de grandes jornais a circular no país. Fenômeno que Sodré (1999) atribui ao "processo de oligopolização ocorrido na economia" e ao "caráter de grande empresa assumido pelos grandes jornais."

Por sua vez, o surgimento da grande empresa midiática, principalmente a partir da incorporação dos novos meios eletrônicos (rádio e televisão), promoveu um considerável aumento no fluxo de capitais para o setor, recursos que precisavam ser remunerados, o que fez com que as empresas buscassem, desesperadamente, ampliar sua participação no mercado por meio de aquisições e da criação de novos veículos. 
Foi assim que Assis Chateaubriand deu início ao que viria a se tornar o maior conglomerado de mídia do Brasil e da América Latina, tendo como referência os grupos midiáticos norte-americanos e ingleses.

(...) Assis menciona, especificamente, organizações e pessoas que levou em conta ao planejar e construir a rede iniciada com O Jornal: "National Broadcasting", "Columbia Broadcasting", Curtis Company, Script Howard, Hearst, Lord Beaberbrook, Lord Camrose, Lord Rothermere e Gomer Berry (CARNEIRO, 1999:90).

Para os jornalistas, as mudanças trazidas pelo novo paradigma irão produzir reações típicas de uma corporação que busca se afirmar como tal. A visão romântica que tinham da atividade, e que até então prevalecia nas redações, foi substituída por uma postura pragmática, que valorizava a formação profissional e criava uma identidade de classe que tinha na importância social do jornalismo seu grande referencial.

A profissionalização veio como uma exigência da ampliação das demandas do mercado, com o crescimento dos meios de comunicação de massa, e a implantação da grande indústria cultural. É nesse momento que aparecem as lógicas da diferenciação social, quando os membros do grupo que atuavam visando à organização do espaço do trabalho buscam limitar a concorrência através do estabelecimento de fronteiras, regularizando a profissão (ABREU, 1998:8).

Essa nova configuração das atividades desenvolvidas pelos jornalistas interfere, a partir de seus critérios de organização e divisão de tarefas típicos da comunicação de massa, no processo de construção da notícia. Daí a disseminação de modelos, manuais e regras de estilo que são impostos aos jornalistas com o intuito de acelerar e controlar os processos produtivos.

A introdução do lead e do manual de redação, já nos anos 1950, coroa esse movimento de padronização da linguagem jornalística. $O$ jornalista Benício Medeiros, ao prefaciar o livro de Cecília Costa, lembrou mudanças significativas no estilo jornalístico introduzidas pelo Diário Carioca:

(...) foi o DC [Diário Carioca] que antes do JB [Jornal do Brasil] expulsou da redação alguns ranços em voga desde o século XIX que obrigavam os redatores a escrever como se usassem fraque e cartola. Tinham, por exemplo, de acrescentar um "excelentíssimo senhor", nos títulos e no corpo das matérias, toda vez que se referiam a um presidente ou a um ministro. No DC Juscelino Kubitschek virou JK, assim como Jânio Quadros virou JQ e João Goulart virou Jango - inovações que na época soaram como verdadeiro escândalo (COSTA, 2011:14). 
O surgimento das grandes empresas jornalísticas, a redução do número de veículos em circulação, o aumento da concorrência e a consequente oligopolização da atividade, repercutiram fortemente na propriedade e na gestão desses empreendimentos. Os financiamentos, as aquisições e fusões passaram a fazer parte da realidade administrativa e contábil das empresas jornalísticas, levando-as a profissionalizar grande parte de sua gestão, o que acabaria por repercutir nas decisões políticas e editoriais.

A formação de redes, com emissoras e jornais espalhados pelas diversas regiões do país - como foi o caso, primeiramente, dos Diários Associados e, em seguida, do Grupo Globo -, levou os grupos midiáticos a desenvolverem estratégias específicas tomando em consideração a realidade em que seus diferentes veículos estavam inseridos.

Muitas vezes, essa necessidade de contemplar questões locais (econômicas, culturais, sociais e, principalmente, políticas) fazia com que a ação desses grupos parecesse contraditória, agindo de maneira diferente nos diferentes lugares em que se achavam presentes.

Aos poucos, os conglomerados foram desenvolvendo a capacidade de lidar com essas diferenças, aperfeiçoando suas estruturas administrativas, cooptando lideranças locais, investindo em tecnologia e entretenimento para alcançar o maior público possível, o que lhes permitiu ampliar sua penetração e influência.

Com o surgimento dos grandes grupos, a imprensa foi obrigada a se tornar mais plural e menos opinativa, valorizando a notícia, a informação, reduzindo o espaço editorial, o que não significa que tenha deixado de se posicionar.

(...) a formação dos primeiros conglomerados de comunicação na década
seguinte (1925), a edição de revistas ilustradas com circulação expressiva
também a partir do final dos anos 20 (O Cruzeiro) e a criação de uma
imprensa de escândalo não podem ser atribuídas, exclusivamente, como
algumas vezes já o foram, a chamada importação de padrões estrangeiros
pelo jornalismo brasileiro (BARBOSA, 1997:99).

Como resultado de todas essas mudanças temos hoje, no Brasil, um modelo de exploração do setor midiático altamente concentrado, com poucos grupos detendo uma grande fatia do mercado, que passou a incluir, além das empresas jornalísticas, empreendimentos nos setores de telecomunicações, entretenimento e 
atividades ligadas à economia da informação, tais como a prestação de serviços de acesso à internet, TV a cabo e telefonia.

O que chama a atenção nesse modelo, que claramente tem sua origem nas mudanças estruturais que vimos apontando ao longo desta pesquisa, é o fato de que os grandes conglomerados midiáticos brasileiros são controlados por grupos familiares, com exceção da Rede Record de Televisão, cujo controle pertence à Igreja Universal do Reino de Deus.

Venício Lima (2015) chama a atenção para os riscos que essa concentração nos meios de comunicação de massa representa para a democracia, especialmente no caso do Brasil.

Os meios de comunicação social não constituem apenas uma atividade
econômica. Ao contrário, são instituições vitais nas democracias liberais. É
através deles que se constrói o espaço público onde a liberdade de
expressão individual é exercida e se forma a opinião pública. Essa espaço
público abriga, por definição, a pluralidade e diversidade de vozes que
existem na sociedade, vale dizer, não pode ser controlado por monopólio ou
oligopólio (LIMA e RABELO, 2015).

Mesmo com a restrição constitucional ${ }^{75}$ ao monopólio e ao oligopólio da mídia, esse reduzido número de grupos midiáticos burla a Lei e atinge, com seus veículos, praticamente a totalidade do território nacional, por meio das Retransmissoras de Televisão (RTVs), conforme demonstra a Tabela 3, a seguir: 
TABELA 3 - ALCANCE DAS REDES DE TV E SUAS RETRANSMISSORAS NO BRASIL

\begin{tabular}{|c|c|c|c|c|}
\hline $\begin{array}{c}\text { REDES/ } \\
\text { GERADORAS } \\
\text { GLOBO }\end{array}$ & $\begin{array}{c}\text { EMISSORAS } \\
\text { PRÓPRIAS }\end{array}$ & $\begin{array}{c}\text { EMISSORAS } \\
\text { AFILIADAS }\end{array}$ & RTVS & TOTAL \\
\hline RECORD & 5 & 79 & 2908 & 3002 \\
\hline SBT & 8 & 43 & 1478 & 1529 \\
\hline BAND & 8 & 19 & 1134 & 1161 \\
\hline REDE TV & 5 & 10 & 161 & 176 \\
\hline $\begin{array}{c}\text { EBC/TV BR } \\
\text { CANÇÃO } \\
\text { NOVA }\end{array}$ & 3 & 7 & 157 & 167 \\
\hline $\begin{array}{c}\text { REDE 21 } \\
\text { TV CULTURA }\end{array}$ & 1 & 2 & 14 & 276 \\
\hline $\begin{array}{c}\text { SOTAL } \\
\text { TOTA }\end{array}$ & 48 & 201 & 7329 & 7578 \\
\hline
\end{tabular}

Fonte: Subcomissão Especial - Formas de financiamento de mídias alternativas, CCTC\&I da Câmara dos Deputados - Outubro de 2013

Jambeiro (2008) aponta que os vínculos entre as redes e as emissoras afiliadas determinam que essas últimas têm de manter, além de uma programação artística e comercial padronizada, um comportamento uniforme sob a coordenação exclusiva da "cabeça" do sistema, normalmente com sede em São Paulo ou no Rio de Janeiro e não podem alterar a programação que retransmitem simultaneamente com toda a rede.

Há, ainda, a presença de denominações religiosas controlando um grande número de veículos de comunicação, notadamente emissoras de televisão e rádio, num claro desrespeito à Constituição que estabelece limites ao número de emissoras pertencentes a uma mesma pessoa jurídica (grupo empresarial).

Tamanha concentração caracteriza, sem sombra de dúvida, o predomínio dos grandes conglomerados empresariais no mercado midiático brasileiro, processo que 
tem origem na primeira metade do século $X X$ e que se expande, de forma exponencial, nessas primeiras décadas do século XXI.

Há, ainda, a presença de conglomerados internacionais, que se dá por meio de acordos legais (a partir da regulamentação da entrada do capital estrangeiro nas empresas midiáticas, em 2002, no governo Fernando Henrique Cardoso) ou por arranjos comerciais de caráter nebuloso, aproveitando-se da ausência de regulamentação e controle dos novos suportes e plataformas tecnológicas para se associarem aos grandes grupos nacionais.

Os riscos que tais condições colocam para o País, além de atingirem diretamente nossos valores culturais, podem implicar na perda da autonomia política, passando pela ampliação de nossa dependência econômica e tecnológica, chegando mesmo a se constituir numa ameaça à liberdade de expressão e, por conseguinte, à estabilidade de nossas instituições e de nossa democracia. 


\section{CONCLUSÕES}

Como foi possível, num país de economia primária, de instituições políticas instáveis e com uma população majoritariamente pobre, iletrada e rural, surgir, ainda na primeira metade do século $X X$, um império midiático com o alcance, a força e a pujança dos Diários Associados? Ou com a qualidade técnica do Grupo Globo?

Que fatores foram decisivos para que, num período de tempo tão curto (pouco mais de cem anos), a imprensa brasileira deixasse de ter um caráter nitidamente partidário, quase iluminista, e se transformasse num negócio capaz de produzir fortuna e poder?

Foram essencialmente essas as questões que nos levaram a refletir sobre a história do jornalismo no Brasil e as mudanças estruturais que nele se sucedem a partir do final do século XIX, momento em que se estabelecem as condições técnicas, econômicas, sociais e políticas que levaram ao surgimento dos nossos primeiros impérios midiáticos.

Os dados, informações, reflexões e conceitos reunidos nesta tese apontam o quanto pode ser produtivo para os estudos ligados às questões envolvendo "Jornalismo e Sociedade" uma aproximação maior com a história do jornalismo brasileiro. Principalmente, se forem considerados aspectos até então pouco discutidos do processo de identificação de novos paradigmas para a atividade jornalística.

Essa estratégia nos permitiu perceber as transformações por que passou o jornalismo no Brasil e como ele se tornou fundamental para a construção e a consolidação de nossas instituições sociais e políticas.

Com essa abordagem, de característica marcadamente histórico-sociológica, buscamos, ainda, entender o percurso que o jornalismo seguiu na sua transição de atividade subordinada às forças que dominavam 0 cenário político para empreendimento de caráter nitidamente empresarial, que vê na notícia um produto que precisa ser comercializado com lucro, ou seja, desvelando como se deu a mudança de um "jornalismo de opinião" para "um jornalismo de informação". 
Acreditamos que essa mudança se caracteriza especialmente pela implantação, por parte das empresas jornalísticas, de novos modelos discursivos, de produção e de gestão voltados, especificamente, para atingir objetivos mercadológicos, como foi o caso da utilização da reportagem e da cobertura de temas mais próximos aos interesses dos cidadãos.

Foi possível distinguir esses novos modelos a partir da aplicação da metodologia weberiana de tipos ideais, o que nos permitiu identificar os elementos presentes na atividade jornalística que formam um conjunto de regras coerentes com essa atividade e que são utilizadas de forma consensual por seus integrantes, constituindo-se naquilo que Thomas Khun chamou de paradigma.

Para chegar a essa construção tipicamente ideal, recuperamos, por meio da historiografia do jornalismo, os diversos momentos em que a atividade jornalística esteve submetida a tensões e mudanças significativas, tanto no que diz respeito às suas características discursivas, quanto aos aspectos inerentes às suas dimensões política, econômica e social. Momentos de inflexão e de aparente descontinuidade do sistema então determinante da prática jornalística.

Ao reconstruirmos a trajetória da imprensa brasileira, constatamos que da sua implantação, em setembro de 1808, até as últimas décadas do século XIX, o jornalismo brasileiro apresenta como características fundamentais o discurso político engajado, a precariedade de suas estruturas de financiamento e gestão, o atraso tecnológico em relação às publicações europeias e norte-americanas e a militância de seus membros.

Nesse período, não havia propriamente uma empresa jornalística, e as que surgem, ainda na primeira metade do século XIX, contam com uma estrutura administrativa incipiente e buscam nos grupos políticos os recursos financeiros para sua manutenção, numa relação intensa e explícita com o universo político-partidário.

No que se refere aos jornalistas, pudemos perceber que, àquela altura, tinham em comum a origem e a formação bacharelesca, eram "brasileiros amigos da nação e da pátria" buscando, por meio do jornalismo, destacar-se politicamente e obter, dessa forma, algum tipo de vantagem. 
Esses atributos aos poucos dão lugar a novas configurações que irão marcar mudanças significativas na imprensa brasileira, constituindo um novo paradigma denominado "Jornalismo Informativo", que surge como resultado das profundas alterações experimentadas pela sociedade brasileira entre o final do século XIX e o início do século XX.

O crescimento populacional, o processo acelerado de urbanização, a diversificação da economia e o surgimento de novas formas de expressão do poder seriam determinantes para as mudanças que levariam a imprensa a ampliar a sua capacidade de influenciar a opinião pública, ao mesmo tempo em que consolidava seu caráter comercial.

Os jornais tornam-se empresas de estrutura administrativa bem definida, reunindo um número maior de funcionários, buscando recursos por meio da comercialização em banca e da venda de espaço publicitário, além de eventualmente recorrerem a agentes financeiros públicos e privados.

Procuram manter discretas suas relações e interesses políticos, dissimulando o adesismo e o partidarismo, explicitando suas posições políticas apenas em momentos críticos ou de extrema gravidade para a ordem constitucional, mas sem deixar de bater à porta do governo, qualquer governo, na busca de verbas e recursos públicos em troca de editoriais menos contundentes ou, simplesmente, da omissão, como denunciaria Rui Barbosa (1990), em $1920 .^{76}$

Nas redações, já é possível encontrar jornalistas de origem mais diversificada, principalmente com a chegada de profissionais que compunham as classes intermediárias, reflexo de uma sociedade que se urbanizava muito rapidamente. Os bacharéis ainda têm espaço significativo, mas se torna comum a presença de jornalistas que aprenderam o ofício nas redações.

Passa a vigorar uma clara divisão de tarefas entre repórteres, redatores e revisores, numa especialização que atende às exigências de um novo modelo de gestão inspirado na Administração Científica.

\footnotetext{
${ }^{76}$ Numa conferência intitulada "O Dever da Verdade", proferida em Salvador, em 1920, na qual repudia, com veemência, as relações escusas entre os governos e a imprensa.
} 
As mudanças atingem, ainda, os assuntos que vão ocupar as páginas dos jornais informativos. As polêmicas e análises políticas inconclusivas dão lugar aos problemas que afetam concretamente a vida dos leitores e à prestação de serviços disponíveis num ambiente urbano cada vez mais complexo.

A simplificação da linguagem também caracteriza o jornalismo informativo, permitindo que todos possam ler e compreender o que os jornais publicam. São utilizadas palavras simples e presentes no cotidiano da população. Além disso, recursos gráficos (ilustrações, desenhos e fotografias) ajudam na compreensão dos assuntos publicados.

Uma das mudanças estruturais mais significativas ocorre em relação ao empreendedor, ou seja, aquele que irá investir e se dedicar à criação e manutenção dos jornais. No jornalismo partidário, não é possível identificar tal figura, pois os veículos que compunham aquele tipo de jornalismo não se constituíam, propriamente, num empreendimento, uma vez que não visavam o lucro.

Em contrapartida, nos jornais que se apresentam como sendo de caráter informativo, a figura do empreendedor não só é claramente perceptível como tem importância fundamental para o seu sucesso. São eles os responsáveis pelas estratégias mercadológicas e pela orientação política de seus veículos, sempre visando ampliar sua influência junto ao leitor e garantir o retorno para o capital investido.

A identificação de todas essas alterações e mudanças na atividade jornalística nos leva a destacar o surgimento, no período indicado, de um novo paradigma cujas consequências repercutiriam fortemente na estrutura e funcionamento das empresas, na ação dos profissionais, no discurso produzido pelo jornalismo e em questões relacionadas à propriedade dos meios de comunicação. $\mathrm{E}$ logicamente, se aplicam, também, às relações que o jornalismo mantém com a sociedade, aí incluído o governo e os diversos grupos ligados ao poder.

E a consequência mais dramática imposta por esse novo modelo foi a redução do número de jornais em circulação no país. A partir de um determinado momento, quando esse novo paradigma se consolida, já não há mais espaço para 
empresas que não atendam às novas exigências mercadológicas, técnicas e econômicas.

A concentração midiática que advém desse arranjo reflete, também, o alcance do novo caráter oligopolista de nossa economia, que afetaria os jornais obrigando-os a assumir a condição de grande empresa, constituída e orientada para o resultado financeiro.

A grande empresa jornalística, por sua vez, criará as condições essenciais para o surgimento dos primeiros grandes conglomerados midiáticos no Brasil. A incorporação de novos meios de comunicação (notadamente os eletrônicos) acarreta num aumento considerável do fluxo de capitais que precisam ser remunerados adequadamente, levando as empresas jornalísticas a ampliar sua presença no mercado por meio de aquisições e pelo lançamento de novos veículos, abrindo caminho para o surgimento de nossos primeiros impérios midiáticos.

Os empreendimentos comandados por Chateaubriand e Marinho serão os pioneiros desse novo modelo que irá mudar, definitivamente, o jornalismo brasileiro, estendendo seus interesses muito além da notícia e da opinião, buscando outras formas de influenciar a opinião pública e investindo em atividades muito mais complexas, como os empreendimentos nos setores de telecomunicações, no entretenimento e, mais recentemente, na economia da informação.

Concluímos, assim, que ao identificarmos as principais mudanças estruturais ocorridas na imprensa brasileira fomos capazes de compreender como se desenvolveu o jornalismo brasileiro, ao longo dos seus mais de dois séculos de existência. Uma trajetória que o afasta do discurso doutrinário - ainda nas primeiras décadas do século XIX - e o transforma num grande negócio, controlado por grupos econômicos cujos interesses estão diretamente relacionados aos novos arranjos mercadológicos de uma economia crescentemente globalizada. 


\section{BIBLIOGRAFIA}

ABREU, Alzira Alves (Coord). Dicionário Histórico-Biográfico Brasileiro - pós 1930. FGV, Rio de Janeiro, 2001

ABREU. Alzira Alves. A imprensa em transição: o jornalismo brasileiro dos anos 50. FGV. Rio de Janeiro, 1996

ABREU, Alzira Alves. Imprensa brasileira - 1930/1990. FGV. Rio de Janeiro, 1991

ABREU, Alzira Alves. Jornalistas: de românticos a profissionais. Antropolítica. Universidade Federal Fluminanse. N.5, pp. 7-19, Niterói, 2ํㅗㄴ semestre de 1998

ADGHIRNI, Zélia Leal. O lugar do jornalismo na comunicação. São Paulo. Revista Líbero, ano IX, no 17, pp. 51-62, Jun 2006

ADGHIRNI, Zélia Leal; e PEREIRA, Fábio Henrique. O Jornalismo em tempo de mudanças estruturais. Intertexto, Porto Alegre: UFRGS, v. 1, n. 24, p. 38-57, janeiro/junho 2011

ADGHIRNI, Zélia Leal. Mudanças estruturais no jornalismo: travessia de uma zona de turbulência. In Jornalismo e Sociedade. Teorias e Metodologias. Org. PEREIRA, Fábio H.; MOURA, Dione Oliveira; e ADGHIRNI, Zélia Leal. Florianópolis, Insular, 2012

ALBUQUERQUE, Afonso de. A modernização autoritária do jornalismo brasileiro. Alceu, v. 10, n. 20 - p. 100 a 115, JAN/JUN 2010

ALMEIDA, Paulo Roberto de. O intelectual Hipólito José da Costa como pensador econômico, em http://www.pralmeida.org/05DocsPRA/1243HipolitoPensEcon.pdf, acessado em 09/07/2014

AMARAL, Gisela Taschner do. Folhas ao Vento: análise de um conglomerado jornalístico no Brasil. Paz e Terra. Rio de Janeiro, 1992

ANATEL - Agência Nacional de Telecomunicações. Total de Emissoras de Rádio Existentes no País, SECOM/PR, 2013

ARON, Raymond. As etapas do pensamento sociológico. São Paulo, Martins Fontes, 1999. 
AUGEY, Dominique e REBILLARD, Franck. Introduction: la dimension économique du journalisme. Les Cahiers du Journalisme no 20 - Automne 2009

BAHIA, Juarez. Jornal, História e Técnica: história da imprensa brasileira. São Paulo, Ática, 1990

BARBOSA, Marialva. Os donos do Rio. Imprensa, Poder e Público. Vício de Leitura, Rio de Janeiro, 2000

BARBOSA, Marialva. Como escrever uma história da imprensa? Palestra proferida no II Encontro Nacional da Rede Alfredo de Carvalho, GT de História, Florianópolis, abril de 2004

BARBOSA, Marialva. História Cultural da Imprensa (1900-2000). Rio de Janeiro. Mauad, 2007

BARBOSA, Marialva. O método e a análise histórica do jornalismo. Trabalho apresentado no GP História do Jornalismo, XIII Encontro dos Grupos de Pesquisas em Comunicação, XXXVI Congresso Brasileiro de Ciências da Comunicação. Manaus, setembro 2013.

BARBOSA, Marialva. Imprensa, Poder e Público: os diários do Rio de Janeiro (18801920). INTERCOM, Revista Brasileira de Comunicação. São Paulo, Vol. XX ํo 2, pág. 87-102, jul/dez 1997

BARBOSA, Rui. A imprensa e o dever da verdade. São Paulo: Com-Arte; Editora da Universidade de São Paulo, 1990

BARDIN, Laurence. Análise de Conteúdo. Lisboa, Edições 70, 1977

BARMAN, R. J. Brazil: the forging of nation (1798-1852). Stanford: Univ. Press, 1988

BAUM, Ana (org). Vargas, agosto de 54. A história contada pelas ondas do rádio. Rio de Janeiro. Garamond, 2004

BIAL, Pedro. Roberto Marinho. Rio de Janeiro. Jorge Zahar Ed., 2004

BLOCH, Marc. Apologia da história ou o ofício do historiador. Rio de Janeiro, Jorge Zahar Ed., 2001 
BONEMY, Helena. Quando os números confirmam impressões: desafios na educação brasileira. Rio de Janeiro. CPDOC, 2003

BREGUEZ, Sebastião. O Jornalismo no final do século XX. Sala de Prensa, Ano III, Vol 2. Junho 2000 (www.saladeprensa.org/art135.htm)

BRESSER-PEREIRA, Luiz Carlos. Desenvolvimento e Crise no Brasil. Atual. São Paulo, 2003

BRIN, Colette; CHARRON, Jean; BONVILLE, Jean. Natureza e transformação do jornalismo. Teoria e pesquisa empíricas. Tradução livre de Márcia Marques e Rogério Dy La Fuente. Nature et transformation du journalisme - Théorie et recherchés empiriques. Quebec: Les Presses de L'Université Laval, 2007. Mimeo, 2008

BRIGGS, Asa e BURKE, Peter. Uma história social da mídia. De Gutenberg à Internet. Rio de Janeiro, Jorge Zahar, 2004

BRAGA, Antônio Carlos de Almeida; NISKIER, Arnaldo; FALCÃO, Joaquim; e SALLES, Mauro. Dr. Roberto: 100 anos, no esporte, na educação, na cultura, no jornalismo. Rio de Janeiro, Consultor, 2005

CABRAL, Eula Dantas Taveira. O negócio da mídia brasileira: suas estratégias, suas políticas. Trabalho apresentado no GP Políticas de Comunicação e Cultura, do IX Encontro dos Grupos/Núcleos de Pesquisas em Comunicação. Intercom - Curitiba, 2009

CABRAL, Eula Dantas. Capital estrangeiro na mídia brasileira - salvação ou desgraça? In: XXVI Congresso Brasileiro de Ciências da Comunicação. Belo Horizonte, 2003. Anais Eletrônicos. Disponível em http://www.portcom.intercom.org.br/navegacaoDetalhe.php?id=42295, acessado em $27 / 04 / 2015$

CALABRE, Lia. A Era do Rádio. Rio de Janeiro. Zahar, 2004

CARNEIRO, Glauco. Brasil primeiro. História dos Diários Associados. Fundação Assis Chateaubriand. Brasília, 1999

CARVALHO, Luiz Maklouf. Cobras criadas. SENAC. São Paulo, 2001

CARVALHO, Maria Alice Rezende de. Irineu Marinho: imprensa e cidade. Editora Globo, Rio de Janeiro, 2012 
CASTRO, Pedro Jorge de (Org.) Carlos Castelo Branco. O jornalista do Brasil. Entrevistas exclusivas a Carlos Chagas. SENAC. Distrito Federal, 2006

CASTRO, Moacir Werneck et al. A Última Hora de Samuel: nos tempos de Wainer. Edições ABI/COPIM, Rio de Janeiro,1993

CHAGAS, Carlos. O Brasil sem retoques: 1808-1964. A história contada por jornais e jornalistas. Vol. 1. Record. Rio de Janeiro, 2001

CHARON, J. e BONVILLE, J. Typologie historique des pratiques journalistiques. In: Colette Brin, Jean Charron et Jean de Bonville, (orgs) Nature et transformation du journalisme. Théories et recherches empiriques. Québec: Les Presses de L'Univversité Laval, p. 141-217, 2004

COSTA, Cecília. Diário Carioca. O jornal que mudou a imprensa brasileira. Cadernos da Biblioteca Nacional. Rio de Janeiro, 2011

COSTELLA, Antônio F. O controle da informação no Brasil. Vozes. Petrópolis, 1970

CRUZ, Heloisa de Faria. São Paulo em papel e tinta. Periodismo e vida urbana 1890 - 1915. Educ/Fapesp. São Paulo, 2000

CUNHA, Nóbrega da. A imprensa americana e seus reflexos no Brasil. Instituto Brasil-Estados Unidos, Rio de Janeiro, 1941

DA SILVA, Luiz Martins; PAULINO, Fernando Oliveira. Jornalismo de centavos, sensacionalismo e cidadania. In: Observatório da Imprensa, Edição 796, março de 2014. Disponível em http://observatoriodaimprensa.com.br/imprensa-emquestao/ ed796 jornalismo de centavos sensacionalismo e cidadania/, acessado em 29/05/2015

DEIRÓ, Pedro Eunápio da Silva. Fragmentos de Estudos da História da Assembleia Constituinte do Brasil. Brasília, Edições do Senado Federal, vol. 66, 2006

DINIZ, Lilia. O primeiro redator de jornais do Brasil. Artigo publicado originalmente na Revista História Viva, edição 532 e acessado no site do "Observatório da Imprensa" $-$

www.observatoriodaimprensa.com.br/news/view/o primeiro redator de jornais do brasil, acessado em 02/07/2014

DORNELLES, Beatriz; LAUX, Morgana Gualdi. Experiência de jornalismo colaborativo na produção do noticiário de blogs do jornal Zero Hora aproxima leitores 
de cadernos de bairro a produtores da notícia. Revista Comunicação Midiática, v. 7, n. 3, p. 234-250, Pontifícia Universidade Católica de Porto Alegre, set/dez 2012

ERBOLATO, Mário. A censura à imprensa durante o Estado Novo. In: Comunicarte, v. 2 , n. 4 p. 131-152, segundo semestre de 1984

FAUSTO, Boris. Revolução de 1930. Historiografia e História. São Paulo. Cia das Letras. FONSECA, Pedro Cezar Dutra. A Revolução de 1930 e a Economia Brasileira. Revista Economi. Brasília, pp. 843-866, Setembro/Dezembro 2012

FONSECA, Virgínia Pradelina da Silveira. O Jornalismo no Conglomerado de Mídia. Reestruturação produtiva sob o capitalismo global. Tese de Doutorado defendida junto à Faculdade de Biblioteconomia e Comunicação da Universidade Federal do Rio Grande do Sul, 2005. Disponível em http://hdl.handle.net/10183/5023, acessado em $13 / 04 / 2015$

FREIRE, Eduardo Nunes. O Design do Jornal Diário. Do tipográfico ao digital. Revista Galáxia, São Paulo, n. 18, p. 291-310, Dez. 2009

FREITAS, Jalmir Nascimento de. Imprensa Nacional. Da linotipia à era digital. 198 anos de História e impressões oficiais. Imprensa Nacional, Brasília, 2006

FURTADO, Celso. Formação Econômica do Brasil. Fundo de Cultura. Rio de Janeiro, 1959

GÁSPARI, Élio. A ditadura encurralada. Cia das Letras. Rio de Janeiro, 2004

GÁSPARI, Élio. A ditadura envergonhada. Cia das Letras. Rio de Janeiro, 2002

GÁSPARI, Élio. A ditadura escancarada. Cia das Letras. Rio de Janeiro, 2002

GOULART, Silvana. Sob a verdade oficial: ideologia, propaganda e censura no Estado Novo. Marco Zero/CNPq, 1990

GLOBO, Memória. Jornal Nacional. A notícia faz história. Jorge Zahar, Rio de Janeiro, 2004.

GOMES, Laurentino. 1808: como uma rainha louca, um príncipe medroso e uma corte corrupta enganaram Napoleão e mudaram a história de Portugal e do Brasil. São Paulo: Editora Planeta do Brasil, 2007 
GONÇALVES, Sérgio Campos. O intelectual cortesão e a civilização: um perfil dos fundadores do IHGB e de sua revista. In Oliveira, Camila A. B.; Mollo, Helena M.; e Buarque, Virgínia A. de Castro. (Orgs) Caderno de resumos e anais do $5^{\circ}$ Seminário Nacional da História da Historiografia: biografia e história intelectual. Ouro Preto, 2011

HALLIN, D. We keep America on top of the world. Nova York. Routledge, 1994

HOFSTADTER, Richard. The American Political Tradition, Nova York. Vintage Books, 1948

HERZ, Daniel. A História Secreta da Rede Globo. Porto Alegre, Dom Quixote Editora, 2009

INNIS, Harold. Empire \& Communications. Press Porcépic, Toronto, 1986

JAMBEIRO, Othon. A regulação da TV no Brasil: 75 anos depois, o que temos? Estudos de Sociologia, Araraquara, v. 13, n. 24, p. 85-104, 2008

KAPLAN, Richard L. The International Encyclopedia of Media Studies. http://onlinelibraty.wiley.com/doi/10.1002/9781444361506.wbiems010/pdf, acessado em $29 / 10 / 2014$

KAPLAN, Richard L. Politics and the American Press. The rise of objectivity, 18651920. Cambridge, University Press, 2002

LACERDA, Carlos et ali. Reportagens que abalaram o Brasil. Ed. Bloch. Rio de Janeiro, 1973.

LARANGEIRA, Álvaro Nunes. Mapeamento documento dos anos dourados de Hipólito José da Costa com a coroa portuguesa. Revista do Instituto Histórico e Geográfico Brasileiro, Rio de Janeiro, № 448 - PP. 11-290, Jul/Set 2010

LENE, Hérica. Memória e história da Comunicação. A participação da Associação Brasileira de Imprensa (ABI) no processo de profissionalização do jornalista. Revista Brasileira de História da Mídia (RBHM). v 2, n. 1, jan/jun 2013. p.19-29

LEVIN, Orna Messer (Org). João do Rio. Antologia de Contos. São Paulo. Lazuli Editora. Cia Editora Nacional. 2010 
LICHTER, S. Robert; Rothman, Stanley; e Lichter, Linda S. The media elite. Bethesda. Maryland. Adler \& Adler, 1986

LIMA, Venício Artur e RABELO, Bráulio Santos. Monopólio ou oligopólio. Contribuição ao debate. Observatório da Imprensa. Edição 833, 13 Jan 2015

LINS DA SILVA, Carlos Eduardo. O adiantado da hora. A influência americana sobre o jornalismo brasileiro. São Paulo. Summus, 1991

LUSTOSA, Isabel. Insultos impressos. A guerra dos jornalistas na independência. 1821-1823. São Paulo. Companhia das Letras, 2000

LUSTOSA, Isabel. O nascimento da imprensa brasileira. Rio de Janeiro. Zahar Editor, 2003.

MACHADO, Humberto Fernandes. A atuação da imprensa do Rio de Janeiro no Império do Brasil. Revista do Instituto Histórico e Geográfico Brasileiro, Rio de Janeiro, no 448, pg. 31-62 - Jul/Set 2010

MARIANI, Bethania. O PCB e a imprensa. Os comunistas no imaginário dos jornais (1922-1989). Revan. Rio de Janeiro, 1998

MARIANI, Bethania. Os primórdios da imprensa no Brasil (ou: de como o discurso jornalístico constrói memória), in Discurso fundador. A formação do país e a construção da identidade nacional. PUCCINELLI, Orlandi (Org). Pontes, Campinas, 2001

MARTINO, Luiz C. As Epistemologias Contemporâneas e o Lugar da Comunicação, in LOPES, Maria Immacolata Vassalo (org) Epistemologia da Comunicação. Loyola, São Paulo, 2003, p. 69-101

MARTINO, Luiz C. Abordagens e Representação do Campo Comunicacional, Comunicação, Mídia e Consumo. São Paulo, vol. 3, N. 8, p. 33-54, Nov 2006

MARTINO, Luiz C. De Qual Comunicação Estamos Falando? In A. Hohlfeldt: L. Martino; V. França (orgs) - Teorias da Comunicação. Vozes. Petrópolis, 2001

MARTINS, Ana Luiza; DE LUCA, Tania Regina (Org.). História da Imprensa no Brasil. São Paulo, Contexto, 2008 
MATIAS, Alberto Borges; BARRETO, Antonio C. P.; GORGATI, Vlamir. Fusões e aquisições no Brasil atual: possibilidades de ocorrência de uma onda. In: SEMEAD, 1., São Paulo, 1996.

http://www.cepefin.com.br/publicados_pdf/fusoes_aquisicoes_brasil_atual.pdf, acessado em 31/03/2015

MELO, José Marques de. Sociologia da Imprensa Brasileira. Petrópolis, Vozes, 1973

MELO, José Marques de. A opinião no jornalismo brasileiro. Petrópolis, Vozes, 1985

MELO, José Marques de. História do pensamento comunicacional: cenários e personagens. São Paulo, Paulus, 2003

MELO, José Marques de. Os primórdios do ensino de jornalismo. Revista Estudos em Jornalismo e Mídia, Vol. 1. № 2 - UFSC, Florianópolis, 2ํㅗemestre de 2004

MELO, José Marques de. Imprensa brasileira: personagens que fizeram história. São Bernardo, IMESP/Metodista, 2005.

MELO, José Marques de. Reinventar o ensino de jornalismo: desafio inadiável no alvorecer do século XXI. Líbero. Revista do Programa de Pós-graduação da Faculdade Cásper Líbero. Ano X, n. 19, pp. 9-16. São Paulo, Jun 2007

MONTEIRO, Pedro Meira. O Reacionário. Revista de História. Jun/2008. Disponível em www.revistadehistoria.com.br/secao/retrato/o-reacionario, acessado em $21 / 07 / 2014$

MORAES, Lúcio F. R. de; MAESTRO FILHO, Antonio Del; e DIAS, Devanir V. O paradigma weberiano da ação social; um ensaio sobre a compreensão do sentido, a criação de tipos ideais e suas aplicações na Teoria Organizacional. Revista de Administração Contemporânea. Vol. 7, nº 2. Curitiba, Abr/Jun 2003.

MORAIS, Fernando. Chatô, o rei do Brasil, a vida de Assis Chateaubriand. São Paulo. Companhia das Letras, 1994.

MOREIRA, Manoel H. T. Construindo um referencial teórico-metodológico para entender os impérios midiáticos brasileiros. Revista Universitas: Arquitetura e Comunicação. V. 10, n. 1, p. 63-70, UniCEUB, Brasília, 2013 (doi:10.5102/uc.v10i1.2039)

MOREIRA, Manoel H. T. A história e a pesquisa em comunicação. Revista Universitas: Arquitetura e Comunicação. v. 8, n.2, p.17-29, UniCEUB, Brasília, 2011 
MOREL, Edmar. A trincheira da liberdade. A história da ABI. Rio de Janeiro, Record. 1985

MOREL, Marco; BARROS, Mariana Monteiro de. Palavra, imagem e poder. O surgimento da imprensa no Brasil do século XIX. Rio de Janeiro. DP\&A, 2003

MORTARA, G. Estudos sobre a utilização do censo demográfico para a reconstrução das estatísticas de movimento da população do Brasil. Revista Brasileira de Estatística, ano II, 3(5), janeiro, 1941

MOTTA, Luiz Gonzaga. The opposition between mediacentric and sociocentric paradigms. Brazilian Journalism Research - Volume 1 - Number 1 - Semester 1 2005

MOTTA, Luiz Gonzaga (Org). Imprensa e Poder. Ed. UnB. Brasília, 2002

MOTTA, Rodrigo Patto Sá. Em guarda contra o perigo vermelho: o anticomunismo no Brasil (1917-1964), Perspectiva. São Paulo, 2002

NASSER, David. O Velho Capitão e outras histórias reais. $3^{a}$ ed. Rio de Janeiro. Ed. O Cruzeiro, 1962

NETO, Lira. Getúlio: Do governo provisório à ditadura do Estado Novo. São Paulo. Companhia das Letras. 2013

NETTO, Accioly. O império de papel. Os bastidores de O Cruzeiro. Sulina. Porto Alegre, 1998

NEVES, Lúcia Maria Bastos P., Cidadania e participação política na época da independência do Brasil. Caderno CEDES, Campinas, V. 22, n. 58, p.47-64, Dez 2002

NOBLE, Iris. Joseph Pulitzer. Front Page Pioneer. New York, Julian Messner Inc. , 1957

NOVAIS, Fernando Antonio e FORASTIERI, Rogério (Org). Introdução: para a Historiografia da Nova História. In Nova História em Perspectiva. São Paulo. Cosac Naify, 2011

ORTRIWANO, Gisela Swetlana. Radiojornalismo no Brasil: fragmentos de história. Revista USP, São Paulo, n. 56, p. 66-85, dezembro/fevereiro 2002-2003 
PASCHOAL, Engel. A trajetória de Octavio Frias de Oliveira. Publifolha. São Paulo, 2007 .

PATTO, Maria Helena Souza. Estado, ciência e política na Primeira República: a desqualificação dos pobres. Revista Estudos Avançados, Vol. 13, no 35, São Paulo, 1999 (ISSN 0103-4014)

PEREIRA, Fábio; ADGHIRNI, Zélia Leal. O Jornalismo em tempo de mudanças estruturais. Intertexto, Porto Alegre: UFRGS, v. 1, n. 24, p. 38-57, janeiro/junho 2011

PEREIRA, F. H. El mundo de los periodistas: aspectos teóricos y metodológicos. Comunicación y Sociedad (Guadalajara), v. 13, 2010, p. 101-124.

PEREIRA, F. H. De Gramsci a lanni: condições histórico-estruturais para a emergência do "intelectual jornalista". In: Anais do II Encontro Nacional de Pesquisadores em Jornalismo, Salvador, 2004.

PEREIRA, Moacir. Gustavo de Lacerda. Os sonhos de um repórter pobre. Jornal da Associação Brasileira de Imprensa (ABI), Edição Especial do Centenário. Vol. 1, p. 34-37, abril 2008

PRICOPIE, Valentina. Colette BRIN, Jean CHARRON et Jean DE BONVILLE (dir.), Nature et transformations du journalisme. Théories et recherches empiriques, Communication, v. 25, 1, 2006.

PULITZER, Joseph. The College of Journalism. North American Review, V. 5, no 178, pp. 642-680, Maio, 1904

RIBEIRO, Ana Paula Goulart. A imprensa da independência e do primeiro reinado: engajamento e mercado. Trabalho apresentado no $\mathrm{V}$ Congresso Nacional de História da Mídia, São Paulo, Jun 2007

RIZZINI, Carlos. O livro, o jornal e a tipografia no Brasil. 1550 - análise dos meios de comunicação da sociedade contemporânea e das manifestações da opinião 1822. Com um breve estudo sobre a informação. Rio de Janeiro, Kosmos, 1946

RIZZINI, Carlos. Hipólito da Costa e o Correio Braziliense. São Paulo, Nacional, 1957

RODRIGUES, Sérgio e FARIA, Tales. Reforma do Diário Carioca: revolução na imprensa brasileira. Griffo/ECO/UFRJ, Rio de Janeiro, 1995 
RODRIGUES, João Carlos. João do Rio. Vida, paixão e obra. Rio de Janeiro. Civilização Brasileira, 2010

RUELLAN, Denis. Le professionnalisme du Flou. Identité et savoir-faire des journalistes français. Grenoble, PUG, 1993

SÁ-SILVA, Jackson Ronie et al. Pesquisa documental: pistas teóricas e metodológicas. Revista Brasileira de História e Ciências Sociais. Ano I, N. 1, Julho de 2009

SANTAELLA, Lucia. Comunicação \& Pesquisa. Hacker, São Paulo, 2001

SAROLDI, Luiz Carlos; MOREIRA, Sonia Virgínia. Rádio Nacional. O Brasil em sintonia. Rio de Janeiro, Zahar, 2005

SCHEDEL, Madalena S. F. Guerra na Europa e Interesses de Portugal. As colônias e o comércio ultramarino. Dissertação de Mestrado. Universidade de Lisboa, 2010

SCHUDSON, Michael. Descobrindo a notícia. Uma história social dos jornais nos Estados Unidos. Petrópolis, RJ, Editora Vozes, 2010

SCHUDSON, Michael. O modelo americano de jornalismo: exceção ou exemplo? Revista Comunicação e Cultura, n. 3, p. 115-130, Universidade Católica Portuguesa, Lisboa, 2007

SCHWARCZ, Lilia Moritz. Por uma historiografia da reflexão, in BLOCH, Marc L. B. Apologia da História, ou, o ofício de historiador. Rio de Janeiro, Zahar Ed. 2002

SEABRA, Roberto. Dois séculos de imprensa no Brasil: do jornalismo literário à era da Internet. In Imprensa e Poder. Org. MOTTA, Luiz Gonzaga. Brasília: Editor Universidade de Brasília. São Paulo: Imprensa Oficial do Estado, 2002

SILVA, Carlos Eduardo Lins da. O adiantado da hora. A influência americana sobre o jornalismo brasileiro. São Paulo, Summus, 1991

SILVA, Hélio e CARNEIRO, Maria Cecília Ribas. Getúlio Vargas. Grupo de Comunicação Três. São Paulo, 1983

SKIDMORE, Thomas E. Brasil: de Getúlio Vargas a Castelo Branco. Paz e Terra. Rio de Janeiro, 1992 
SOARES, Martinho Tomé Martins. História e Ficção em Paul Ricoeur e Tucídides. Tese de Doutorado, Universidade de Coimbra, Portugal, 2010

SOBRINHO, Alexandre Barbosa Lima. Antologia do Correio Braziliense. Cátedra, Rio de Janeiro/Brasília. 1977

SOBRINHO, José Bonifácio de Oliveira. O livro do Boni. Casa da Palavra. Rio de Janeiro, 2011

SODRÉ, Muniz. O social irradiado! Violência urbana, neogrotesco e mídia. São Paulo, Cortez, 1996

SODRÉ, Nelson Werneck. A História da Imprensa no Brasil. Rio de Janeiro. Mauad, 1999

SOUSA, Jorge Pedro. Uma história breve do jornalismo no Ocidente. 2008. Universidade Fernando Pessoa e Centro de Investigação Media \& Jornalismo www.bocc.ubi.pt - http://www.bocc.ubi.pt/pag/sousa-jorge-pedro-uma-historia-brevedo-jornalismo-no-ocidente.pdf , acessado em 18/02/2013.

SOUSA, Jorge Pedro. A discussão sobre a introdução do ensino superior de jornalismo em Portugal: das primeiras menções ao primeiro curso. Verso e Reverso Revista da Comunicação. V. 23, UniSINOS, São Leopoldo, 2009, obtida no endereço eletrônico http://revistas.unisinos.br/index.php/versoereverso/article/view/5767/3137, acessado em $16 / 03 / 2015$.

TAVARES, José Nilo. Gênese do Império Associado de Assis Chateaubriand, In: Revista Comunicação e Sociedade. Cortez. São Paulo, março, 1982

TRAGTENBERG, Maurício. Atualidade de Max Weber. Introdução à edição brasileira de Metodologia das Ciências Sociais de Max Weber, (XI a L), São Paulo, Editora da UNICAMP, 1973

TRAQUINA, Nelson. Teorias do jornalismo: porque as notícias são como são. Vol. 1. Florianópolis. Insular, 2004

TRAQUINA, Nelson. Teorias do jornalismo: a tribo jornalística - uma comunidade interpretativa transnacional. Vol. 2. Florianópolis. Insular, 2008

TRAVANCAS, Isabel S. O Mundo dos Jornalistas. São Paulo, Summus, 1993 
VAINER, Bruno Zilberman. Breve histórico acerca das constituições do Brasil e do controle de constitucionalidade brasileiro. Revista Brasileira de Direito Constitucional. № 16 - Jul/Dez 2010. P. 161-191

VIANNA, Hélio. D. Pedro I, jornalista. Melhoramentos, São Paulo, 1967

VIZEU, Alfredo. O primeiro manual de redação do Brasil. Publicado no site do "Observatório da Imprensa", 2007. http://www.observatoriodaimprensa.com.br/news/view/o_primeiro_manual_de_redacao_do_b rasil, acessado em 30/10/2014, às $19 \mathrm{~h} 46$

WEBER, Max. Sociologia da Imprensa: um programa de pesquisa. Lua Nova ํㅡㄴ 5556, 2002, baseado na publicação da Revista Española de Investigaciones Sociales REIS, № 57/1992, PP. 251-259. Tradução de Encarnación Moya.

WEBER, Max. A ética protestante e o espírito do capitalismo. Pioneira Thomson Learning. São Paulo. 2003. 2ª Ed.

WEBER, Max. Metodologia das ciências sociais. Cortez Editora. São Paulo, 2001

WEBER, Max. Economia e Sociedade. Fundamentos da Sociologia Compreensiva. Editora Universidade de Brasília. 1998

WEBER, Max. Ciência e Política: duas vocações. Cultrix, São Paulo, 2011

WINCKELMANN, Johannes. Prefácio à quinta edição de Economia e Sociedade. Fundamentos da Sociologia Compreensiva. Editora Universidade de Brasília. 1998

WOLF, Mauro. Teorias da Comunicação. Presença, 6ª Ed. , Lisboa, 2001

WOLFF, Michael. O dono da mídia. Os segredos de Rupert Murdoch, o magnata das comunicações do século XX. Rio de Janeiro, Elsevier, 2009 
ANEXOS 


\begin{abstract}
ANEXO 1
Decreto-Lei ํㅜ 910, de 30 de Novembro de 1938

Dispõe sobre a duração e condições do trabalho em empresas jornalísticas.

O PRESIDENTE DA REPÚBLICA:
\end{abstract}

Considerando que as medidas de proteção ao trabalhador, no que dizem respeito ao horário e às condições de trabalho, já atingiram a maioria dos empregados, por meio de legislação especial;

Considerando que, entretanto, esse regime de proteção ainda não se extende de um modo geral aos que dedicam suas atividades às empresas jornalísticas;

Considerando que esses trabalhadores intelectuais são merecedores do amparo do Estado, tanto mais quando este deve à Imprensa valiosa colaboração na obra de progresso nacional e no engrandecimento do Brasil; e, finalmente,

Usando da faculdade que lhe confere o art. 180 da Constituição,

\title{
DECRETA:
}

\section{CAPÍTULO I}

\section{DOS ESTABELECIMENTOS E PESSOAS}

Art. 1ํㅡㄴ Os dispositivos do presente decreto-lei se aplicam aos que, nas empresas jornalísticas, prestem serviços como jornalistas, revisores, fotógrafos, ou na ilustração, com as exceções nele previstas.

$\S 1^{\circ}$ Entende-se como jornalista o trabalhador intelectual cuja função se extende desde a busca de informações até à redação de notícias e artigos e à organização, orientação e direção desse trabalho.

$\S 2^{\circ}$ Consideram-se empresas jornalísticas, para os fins deste decreto-lei, aquelas que têm a seu cargo a edição de jornais, revistas, boletins e periódicos, ou a distribuição de noticiário, e, ainda, as de radiodifusão em suas secções destinadas à transmissão de notícias e comentários. 
Art. 2ํNão se compreendem no regime deste decreto-lei:

- os empregados de escritório e de portaria aos quais se aplica, em matéria de duração do trabalho, o disposto no decreto n. 22.033, de 29 de outubro de 1932;

- os gráficos sujeitos ao regime do decreto n. 21.364 , de 4 de maio de 1932 ;

- os empregados de estabelecimentos de natureza pública ou paraestatal.

\section{CAPÍTULO ॥}

\section{DA DURAÇÃO DO TRABALHO}

Art. $3^{\circ} \mathrm{A}$ duração normal do trabalho dos empregados compreendidos neste decreto-lei não deverá exceder de cinco horas, tanto de dia como à noite.

Art. 4ํ Poderá a duração normal do trabalho ser elevada a sete horas, mediante acordo escrito, em que se estipule aumento de ordenado, correspondente ao excesso do tempo de trabalho, e em que se fixe um intervalo destinado a repouso ou a refeição.

Parágrafo único. Para atender a motivos de força maior, poderá o empregado prestar serviços por mais tempo do que aquele permitido, neste decreto-lei. Em tais casos, porem, o excesso deve ser comunicado à Inspetoria do Departamento Nacional do Trabalho, ou às Inspetorias Regionais, do Ministério do Trabalho, Indústria e Comércio, dentro de cinco dias, com a indicação expressa dos seus motivos.

Art. $5^{\circ}$ As horas de serviço extraordinário, quer as prestadas em virtude de acordo, quer as que derivem das causas previstas no parágrafo único do artigo anterior, não poderão ser remuneradas com quantia inferior à que resultar do quociente da divisão da importância do salário mensal por 150 (cento e cincoenta), para os mensalistas, e do salário diário por 5 (cinco), para os diaristas, acrescida de, pelo menos, $25 \%$ (vinte e cinco por cento). 
Art. 6을 Os dispositivos dos arts. $3^{\circ}, 4^{\circ}$ e $5^{\circ}$ não se aplicam àqueles que exercem as funções de redator-chefe, secretário, sub-secretário, chefe e sub-chefe de revisão, chefe de oficina de ilustração e chefe de portaria.

Parágrafo único. Não se aplicam, do mesmo modo, os artigos $3^{\circ}$, 4ํㅡㄹ e $5^{\circ}$ aos que se ocuparem unicamente em serviços externos.

Art. $7^{\circ} \mathrm{A}$ cada seis dias de trabalho efetivo corresponderá um dia de descanso obrigatório, que coincidirá com o domingo, salvo acordo escrito em contrário, no qual será expressamente estipulado o dia em que se deve verificar o descanso.

Art. 8 Em seguida a cada período diário de trabalho haverá um intervalo mínimo de dez horas, destinado ao repouso.

Art. 9ำ Será computado como de trabalho efetivo o tempo em que o empregado estiver à disposição do empregador.

CAPÍTULO III

\section{DA FISCALIZAÇÃO}

Art. 10. Para os efeitos da fiscalização da execução do presente decreto-lei, os empregadores são obrigados ao seguinte:

- manter afixado em lugar visivel de cada secção atingida por este decreto-lei um quadro discriminativo do horário de cada empregado que nela trabalhe, devendo o mesmo conter a indicação, quando tal ocorra, de se tratar de empregado em serviço externo;

- manter um livro, ou relógio, de ponto, em que se consignem as horas de entrada, descanso e saída do pessoal em serviço interno ou a presença do de serviço externo quando a ela obrigado;

- manter um livro de registro em que sejam anotados os dados referentes aos empregados relativamente à sua identidade, registo e carreira profissional, admissão, condições de trabalho, férias e obrigações das leis de acidentes, nacionalização e seguros sociais. 
Parágrafo único. O Departamento Nacional do Trabalho expedirá os necessários modelos do quadro, livros de ponto e registo de que trata este artigo.

Art. 11. A fiscalização dos dispositivos deste decreto-lei compete não só ao Departamento Nacional do Trabalho e Inspetorias Regionais do Ministério do Trabalho, Indústria e Comércio, por seus orgãos competentes, como ainda aos sindicatos profissionais, na forma do decreto n. 22.300, de 4 de janeiro de 1933.

\section{CAPÍTULO IV}

\section{DO EXERCÍCIO DA PROFISSÃO JORNALÍSTICA}

Art. 12. Somente poderão ser admitidos ao serviço das empresas jornalísticas como jornalistas, locutores, revisores e fotógrafos os que exibirem prova de sua inscrição no Registo da Profissão Jornalística, a cargo do Serviço de Identificação Profissional do Departamento Nacional do Trabalho, no Distrito Federal, e das Inspetorias Regionais do Ministério do Trabalho, Indústria e Comércio, nos Estados e Território do Acre.

Art. 13. Para o registo de que trata o artigo anterior, deve o requerente exibir os seguintes documentos:

- prova de nacionalidade brasileira;

- folha corrida;

- prova de que não responde a processo ou não sofreu condenação por crime contra a segurança nacional;

- carteira profissional.

$\S 1^{\circ}$ Aos profissionais devidamente registados será feita a necessária declaração na carteira profissional.

$\S 2^{\circ}$ Aos novos empregados será, concedido o prazo de 60 dias para a apresentação da carteira profissional, fazendo-se o registo condicionado a essa apresentação e expedindo-se um certificado provisório para aquele período. 
$\S 3$ ํㅜㄹ Para os empregados das empresas jornalísticas que editem publicações ou mantenham noticiário em língua estrangeira, será dispensavel a prova da alínea a deste artigo, mantidas porém, com relação a essas empresas, as exigências da legislação vigente sobre nacionalização do trabalho e atividade de estrangeiros.

$\S 4^{\circ}$ Salvo em se tratando de empregado de empresas a que alude o parágrafo anterior, não se concederá registo àqueles que prestem serviços remunerados a países estrangeiros ou a empresas constituídas com maioria de capital estrangeiro.

\section{CAPÍTULO V}

\section{DAS PENALIDADES}

Art. 14. A infração de qualquer dispositivo deste decreto-lei será punida com multa de 100\$000 (cem mil réis) a 1:000\$000 (um conto de réis), elevada ao dobro em caso de reincidência e aplicada, no Distrito Federal, pelo diretor do Departamento Nacional do Trabalho e, nos Estados e Território do Acre, pelos Inspetores Regionais do Ministério do Trabalho, Indústria e Comércio.

Parágrafo único. A penalidade será sempre aplicada no grau máximo:

- si se apurar o emprego de artifício, ou simulação, para fraudar a aplicação deste decreto;

- si for admitido ao serviço jornalista não registado na forma do art. 12.

Art. 15. O recurso de decisão que impuser penalidade e a cobrança das multas regulam-se pelo disposto no decreto n. 22.131, de 23 de novembro de 1932, e a lavratura dos autos de infração pelo decreto n. 22.300, de 4 de janeiro de 1933. 
Art. 16. Continuam em vigor, para todos os empregados em empresas jornalísticas, sem embargo da distinção estabelecida no capítulo I deste decreto-lei, os dispositivos referentes a férias, previdência social, acidentes de trabalho e moléstias profissionais, nacionalização, estabilidade e quantos mais, em matéria de proteção assistência ao trabalhador ou de previdência social, a eles se referem de modo especial, ou de modo geral se aplicam ao comércio e à indústria.

Art. 17. O Governo Federal, de acordo com os Governos Estaduais, promoverá a criação de escolas de preparação ao jornalismo, destinadas à formação dos profissionais da imprensa.

Parágrafo único. Criadas as escolas, de que trata este artigo, a inscrição no Registo da Profissão Jornalística só se fará, para os novos profissionais, em face dos diplomas do curso feito ou exames prestados em tais escolas.

Art. 18. Instalado o Registo da Profissão Jornalística, será estabelecido o prazo de 120 dias para a inscrição daqueles que já se encontrem no exercício da profissão.

Art. 19. Serão nulos de pleno direito quaisquer acordos destinados a burlar os dispositivos deste decreto-lei, sendo vedado aos empregadores rebaixar salários por motivo de sua vigência.

Art. 20. Não haverá incompatibilidade entre o exercício de qualquer função remunerada, ainda que pública, e o de atividade jornalística, sendo permitida a acumulação de proventos de aposentadoria ou pensão decorrentes de contribuição paga para as instituições de previdência social a que estejam sujeitas tais profissões, até ao máximo de 2:000\$000, observadas as disposições do decreto-lei n. 819 , de 17 de outubro de 1938.

Art. 21. A empresa jornalística que deixar de pagar pontualmente, e na forma acordada, os salários devidos a seus empregados terá suspenso 0 seu funcionamento, até que se efetue o pagamento devido.

$\S 1^{\circ}$ Para os efeitos do cumprimento deste artigo, deverão os prejudicados reclamar contra a falta de pagamento perante a autoridade competente, e, proferida a condenação, desde que a empresa não a cumpra, ou em caso de recurso, não 
deposite o valor da indenização, a autoridade que proferir a condenação oficiará à autoridade judiciária competente para a matrícula.

$\S 2^{\circ}$ Em igual pena de suspensão incorrerá a empresa que deixar de recolher as contribuições devidas às instituições de previdência social.

$\S 3^{\circ}$ É considerado privilegiado, com precedência sobre os demais, o crédito dos empregados resultante de salários ou férias devidos, bem assim o de instituições de previdência social pelas contribuições que lhes couberem.

$\S 4^{\circ}$ Considera-se como justa causa para a retirada do empregado, dando-lhe direito a reclamar as indenizações legais, o atrazo no pagamento de salários devidos.

Art. 22. O presente decreto-lei entrará em vigor 60 dias depois de sua publicação, e dentro desse prazo expedirá o Departamento Nacional do Trabalho os modelos de que trata o art. 10, parágrafo único.

Art. 23. Revogam-se as disposições em contrário.

Rio de Janeiro, 30 de novembro de $1938,117^{\circ}$ da Independência e $50^{\circ}$ da República.

GETÚLIO VARGAS

Waldemar Falcão

Publicação:

- Diário Oficial da União - Seção 1 - 3/12/1938, Página 24335 (Publicação Original)

- Coleção de Leis do Brasil - 1938, Página 179 Vol. 4 (Publicação Original)

Obtido em http://www2.camara.leg.br/legin/fed/declei/1930-1939/decreto-lei910-30-novembro-1938-349925-publicacaooriginal-1-pe.html, acesso em 17/03/2015 


\begin{abstract}
ANEXO 2
DECRETO-LEI N. 5.480 - DE 13 DE MAIO DE 1943

Institue o curso de jornalismo no sistema de ensino superior do país, e dá
\end{abstract} outras providências

O Presidente da República, usando da atribuição que the confere o art. 180 da Constituição,

decreta:

Art. 1 Fica instituído, no sistema de ensino superior do país, o curso de jornalismo.

Art. $2^{\circ} \mathrm{O}$ curso de jornalismo tem por finalidade ministrar conhecimentos que habilitem de um modo geral para a profissão de jornalista.

Art. 3응 $\mathrm{O}$ curso de jornalismo será ministrado pela Faculdade Nacional de Filosofia com a cooperação da Associação Brasileira de Imprensa e dos sindicatos representativos das categorias de empregados e de empregadores das empresas jornalísticas.

Art. 4ํ Para a organização e funcionamento do curso de jornalismo nos estabelecimentos de ensino não federais, observar-se-á o disposto no decreto-lei n. 421, de 11 de maio de 1938.

Art. 5o A estrutura do curso de jornalismo, e bem assim as condições de matrícula e o regime escolar regular-se-ão por decreto.

Art. 6o O Ministro da Educação baixará instruções, inclusive sobre as matérias referidas no artigo anterior, e dará providências, que possibilitem desde logo o início do curso de jornalismo da Faculdade Nacional de Filosofia.

Art. $7^{\circ}$ Este decreto-lei entrará em vigor na data de sua publicação, ficando revogadas as disposições em contrário.

Rio de Janeiro, 13 de maio de $1943,122^{\circ}$ da Independência e $55^{\circ}$ da República. 
GETULIO VARGAS

Gustavo Capanema

Fonte: $\quad$ www.fenaj.org.br/.../curso de jornalismo - decreto-lei 5480-43.doc, acesso em 17/03/2015 


\begin{abstract}
ANEXO 3
DECRETO № 21.111, DE 1ํ DE MARÇO DE 1932
\end{abstract}

Aprova o regulamento para a execução dos serviços de radiocomunicação no território nacional.

O Chefe do Governo Provisório da República dos Estados Unidos do Brasil, usando das atribuições que lhe conferem os arts. $1^{\circ}$ e $4^{\circ}$ do decreto n. 19.398, de 11 de novembro de 1930 ,

\title{
DECRETA:
}

Art. $1^{\circ}$ Fica aprovado o regulamento que com este baixa, assinado pelo ministro de Estado dos Negócios da Viação e Obras Públicas, para a execução dos serviços de radiocomunicação no território nacional, a que se refere o decreto $\mathrm{n}$. 20.047, de 27 de maio de 1931.

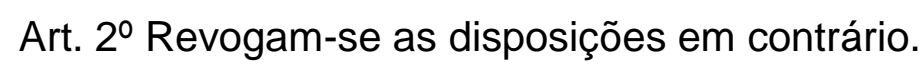

Rio de Janeiro, 1 de março de 1932,

$111^{\circ}$ da Independência e 44ํำ da República.

\section{GETULIO VARGAS}

José Américo de Almeida.

Fonte: http://www2.camara.leg.br/legin/fed/decret/1930-1939/decreto-21111-1-marco1932-498282-publicacaooriginal-81840-pe.html, acesso em 23/03/2015 
ANEXO 4

TOTAL DE EMISSORAS DE RÁDIO EXISTENTES NO BRASIL

TOTAL RADIO STATION EXISTENT IN BRAZIL

\begin{tabular}{|c|c|c|c|c|c|c|c|c|}
\hline & & & \\
\hline REGIÄO / REGION & ESTADO / STATE & ONDAS MÉDIAS & $\begin{array}{l}\text { FREQUENCIA } \\
\text { MODULADA }\end{array}$ & TOTAL & & & & \\
\hline BRASIL & BRASIL & 1.777 & 2.964 & 4.741 & BRASIL & BRASIL & & 4.741 \\
\hline \multirow[t]{8}{*}{ NORTE / NORTH } & TOTAL & 138 & 290 & 428 & \multirow{8}{*}{ NORTE / NORTH } & TOTAL & 428 & \\
\hline & PARÁ & 46 & 99 & 145 & & PARÁ & 145 & \\
\hline & RONDÔNIA & 23 & 53 & 76 & & RONDÔNIA & 76 & \\
\hline & AMAZONAS & 27 & 40 & 67 & & AMAZONAS & 67 & \\
\hline & TOCANTINS & 19 & 42 & 61 & & TOCANTINS & 61 & \\
\hline & ACRE & 11 & 23 & 34 & & ACRE & 34 & \\
\hline & AMAPÁ & 6 & 19 & 25 & & AMAPÁ & 25 & \\
\hline & RORAIMA & 6 & 14 & 20 & & RORAIMA & 20 & \\
\hline \multirow{10}{*}{$\begin{array}{l}\text { NORDESTE / } \\
\text { NORTHEAST }\end{array}$} & TOTAL & 431 & 665 & 1.096 & \multirow{10}{*}{$\begin{array}{l}\text { NORDESTE / } \\
\text { NORTHEAST }\end{array}$} & TOTAL & \multicolumn{2}{|l|}{1.096} \\
\hline & BAHIA & 97 & 160 & 257 & & BAHIA & 257 & \\
\hline & CEARÁ & 101 & 135 & 236 & & CEARÁ & 236 & \\
\hline & PERNAMIBUCO & 41 & 102 & 143 & & PERNAMBUUCO & 143 & \\
\hline & PARAIBA & 34 & 71 & 105 & & PARAÍBA & 105 & \\
\hline & MARANHÃO & 43 & 52 & 95 & & MARANHÃO & 95 & \\
\hline & PIAUI & 51 & 42 & 93 & & PIAUI & 93 & \\
\hline & RIO GRANDE DO NOR.. & 33 & 32 & 65 & & RIO GRANDE DO NORTE| & 65 & \\
\hline & ALAGOAS & 18 & 44 & 62 & & ALAGOAS & 62 & \\
\hline & SERGIPE & 13 & 27 & 40 & & SERGIPE & 40 & \\
\hline \multirow{5}{*}{$\begin{array}{l}\text { SUDESTE / } \\
\text { SOUTHEAST }\end{array}$} & TOTAL & 543 & 1.044 & 1.587 & \multirow{5}{*}{$\begin{array}{l}\text { SUDESTE / } \\
\text { SOUTHEAST }\end{array}$} & TOTAL & 1.587 & \\
\hline & SÃO PAULO & 274 & 488 & 762 & & SÃO PAULO & 762 & \\
\hline & MINAS GERAIS & 184 & 396 & 580 & & MINAS GERAIS & 580 & \\
\hline & RIO DE JANEIRO & 60 & 102 & 162 & & RIO DE JANEIRO & 162 & \\
\hline & ESPIRITO SANTO & 25 & 58 & 83 & & ESPIRITO SANTO & 83 & \\
\hline \multirow[t]{4}{*}{ SUL / SOUTH } & TOTAL & 474 & 630 & 1.104 & \multirow[t]{4}{*}{ SUL / SOUTH } & TOTAL & 1.104 & \\
\hline & RIO GRANDE DO SUL & 188 & 263 & 451 & & RIO GRANDE DO SUL & 451 & \\
\hline & PARANÁ & 179 & 210 & 389 & & PARANÁ & 389 & \\
\hline & SANTA CATARINA & 107 & 157 & 264 & & SANTA CATARINA & 264 & \\
\hline \multirow{5}{*}{$\begin{array}{l}\text { CENTRO-OESTE / } \\
\text { MID-WEST }\end{array}$} & TOTAL & 191 & 335 & 526 & \multirow{5}{*}{$\begin{array}{l}\text { CENTRO-OESTE } \\
\text { I MID-WEST }\end{array}$} & TOTAL & 526 & \\
\hline & GOIÁS & 60 & 132 & 192 & & GOIÁS & 192 & \\
\hline & MATO GROSSO & 65 & 96 & 161 & & MATO GROSSO & 161 & \\
\hline & MATO GROSSO DO SUL & 55 & 76 & 131 & & MATO GROSSO DO SUL & 131 & \\
\hline & DISTRITO FEDERAL & 11 & 31 & 42 & & DISTRITO FEDERAL & 42 & \\
\hline
\end{tabular}

Fonte / Source:

Anatel, Marco 2013. Levantamento elaborado pelo Núcleo de Mídia da SECOM/PR 


\section{ANEXO 5}

Editorial de Roberto Marinho sobre o caso time-life

\section{A TV GLOBO E O GRUPO TIME-LIFE}

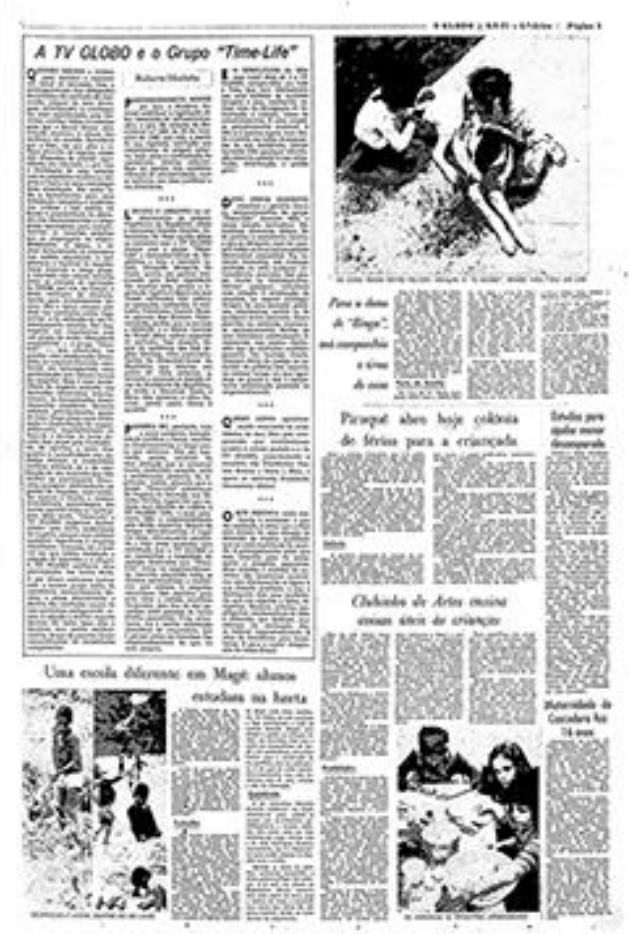

"Quando recebi a licença para instalar e explorar um canal de televisão, com a contraprestação das obrigações decorrentes do contrato de concessão, julguei de meu dever, para corresponder à confiança em mim manifestada pelo governo, envidar todos os esforços para que o Brasil tivesse uma estação modelar, à altura das melhores do mundo. Reconheci que o país, em que pese o esforço pioneiro de alguns, ainda não dispunha de grande experiência em televisão, e por isso a instalação de uma estação com os requisitos modernos exigira a busca de uma tecnologia mais atualizada. Por outro lado, o investimento para uma instalação completa e moderna era vultoso e não existia no Brasil a possibilidade de obtenção dos financiamentos a longo prazo necessários para complementar os recursos próprios que eu empregaria no empreendimento. A época, a espiral inflacionária já começava sua subida alarmante, o que afastava a hipótese de empréstimos internos a longo prazo. A televisão não estava incluída entre os campos de aplicação do BNDE, que era, ao tempo, a fonte exclusiva de financiamento para investimentos 
iniciais. Daí o único recurso possível nas condições então vigorantes, o de obtenção de um financiamento externo. Por isso, negociei um empréstimo com um grupo da maior idoneidade empresarial - o grupo Time-Life —, que concordou em prestar uma colaboração financeira ao empreendimento, recebendo em contrapartida uma participação nos futuros lucros da empresa. A modalidade jurídica adotada foi a da celebração de um contrato que não atribui ao participante financeiro qualquer interferência na gestão da empresa, reservando-Ihe apenas o direito de receber determinada percentagem dos lucros quando estes se verificarem. Assinei com o mesmo grupo outro de assistência exclusivamente técnica, a prazo determinado, e dentro das condições usuais de tais acordos, assegurando assim à estação o melhor suporte técnico. De todos esses atos tiveram prévio conhecimento as autoridades brasileiras.

Posteriormente houve por bem o governo federal modificar a legislação sobre concessão de telecomunicações, o que fez através do Decreto-Lei no 236, de 28 de fevereiro de 1967, que cria, a partir de sua vigência, restrições aos empréstimos de origem externa, bem como à contratação de assistência técnica exterior. Essa lei, porém, não continha cláusula de retroatividade, nem se aplicava aos atos jurídicos a ela anteriores.

Levado o assunto ao conhecimento do próprio presidente da República, então o marechal Castello Branco, determinou ele fosse ouvido sobre os contratos que a TV Globo firmou com o grupo Time-Life o consultor geral da República, e este, o honrado jurista Adroaldo Mesquita da Costa, emitiu um parecer concluindo pela total legalidade dos mesmos atos, porque a legislação vigente à época em que foram celebrados não vedava as operações realizadas. O eminente presidente Castello Branco aprovou esse parecer, determinando, porém, que se ouvisse o Contei e o Banco Central do Brasil sobre outros aspectos do contrato. Isso ensejou, depois da audiência dos dois órgãos técnicos, novo pronunciamento do consultor geral da República, que reiterou seu ponto de vista anterior, e, enviado o processo à decisão final do presidente da República, já então o marechal Costa e Silva, este aprovou o novo parecer, pondo assim termo à questão.

Poderia eu, portanto, com a mais completa tranqüilidade jurídica e moral, manter os financiamentos a longo prazo que obtivera. Não me convinha, porém, 
usufruir de uma situação que se constitui numa verdadeira exceção, ante a modificação posterior da legislação. Posso anunciar com satisfação que a TV Globo e eu assumimos a totalidade da posição financeira que o grupo Time-Life tinha no empreendimento, havendo adquirido todos os direitos patrimoniais e creditórios que cabiam à empresa americana. Isso significa para mim novo e vultoso sacrifício financeiro, pois tive de dar garantias reais pessoais às novas dívidas assumidas. Filo, entretanto, fiel à minha orientação invariável de empresário, que é pensar antes no interesse dos empreendimentos do que no meu próprio.

E o resultado de toda essa luta? Está aí, é a TV Globo, estação-líder em todo o país, que leva diariamente aos seus milhões de ouvintes imagem e som, realizando valiosa obra de divulgação de informação e cultura, como de entretenimento. $E$ uma empresa genuinamente nacional. $E$ não o é apenas agora, mas desde o início, em todos os momentos de sua existência, jamais havendo tido qualquer orientação externa quanto à sua orientação, informação, e gestão geral.

Devo neste momento ressaltar a perfeita lisura do comportamento do grupo Time-Life durante toda a nossa relação contratual. Em nenhum momento deixou de prestar a assistência técnica a que se obrigara, nem de cumprir todos os compromissos financeiros assumidos. Em nenhum momento, sob nenhum pretexto ou ante qualquer circunstância, procurou esse grupo, direta ou indiretamente, exercer qualquer influência com relação à orientação da empresa, ou sugerir qualquer direção às suas posições políticas, econômicas, sociais ou de qualquer outra natureza.

O que importa neste momento é constatar o que foi realizado, é saber que o país está dotado de uma estação de televisão da mesma qualidade que as mais modelares do mundo. E principalmente saber que essa empresa goza do maior apoio e simpatia populares. Seus milhões e milhões de ouvintes são brasileiros autênticos, que diariamente se ligam à sua estação predileta, e que a distinguem com uma preferência que nos orgulha a todos, dirigentes, técnicos, artistas, empregados, colaboradores de toda a natureza, que dedicam seus esforços na realização desse notável empreendimento. E obra de brasileiros para brasileiros. $\mathrm{E}$ para a maior integração do nosso Brasil. 
Roberto Marinho. O Globo, 08/07/1971"

Disponível em http://www.robertomarinho.com.br/vida/opiniao/detalhes-deverbete-2.htm, acessado em 30/04/2015 
ANEXO 6

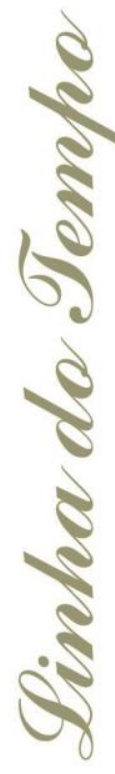

Nasce a imprensa brasileira

Gazeta do Rio de Janeiro

Correio Braziliense

Início do jornalismo áulico

Acorientada
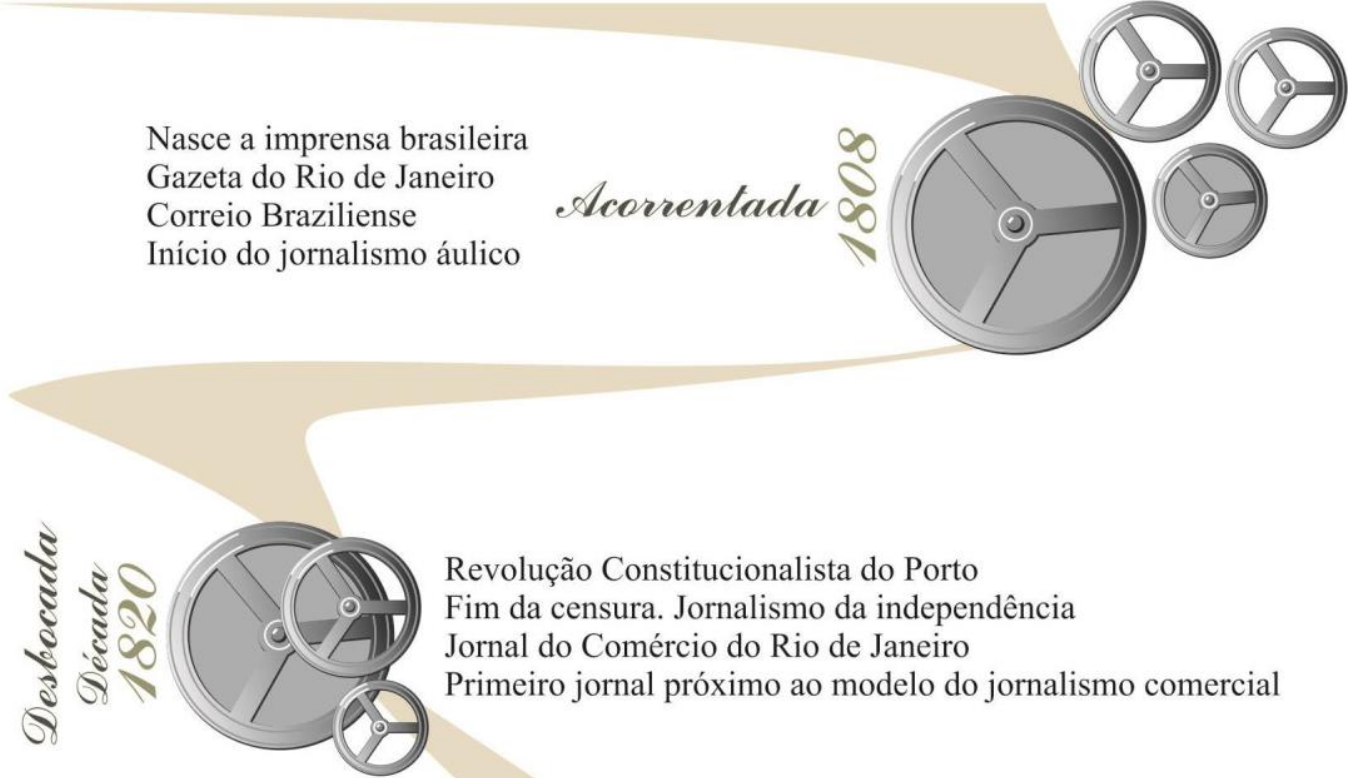

Apaixonada

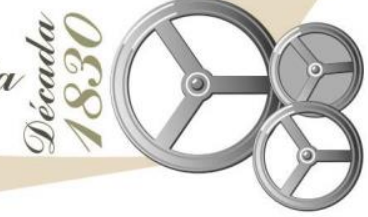

Fim do primeiro reinado (1831)

Jornais doutrinários, iluministas Pasquins

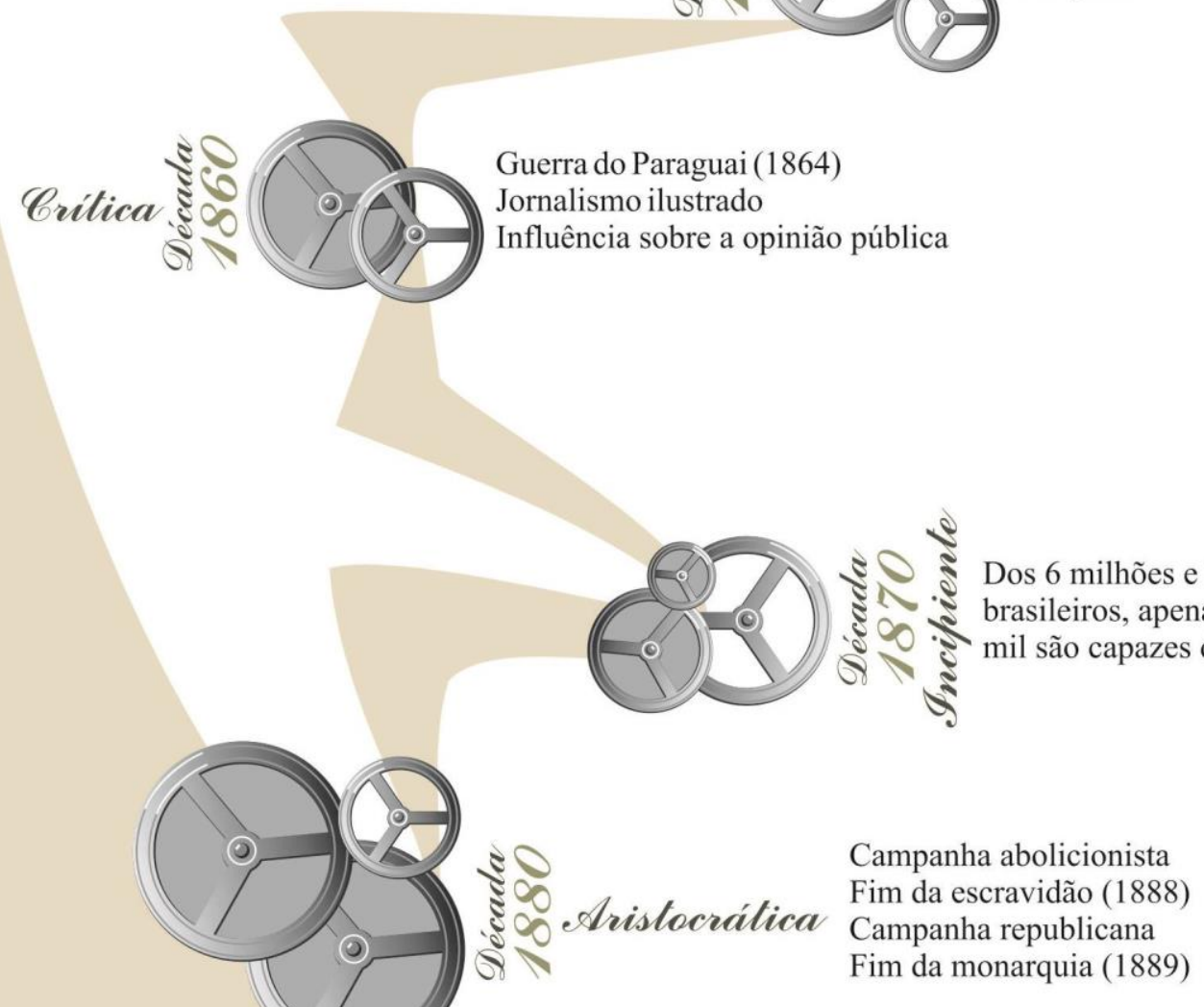


O repórter João do Rio

Inovações técnicas

Aumento de tiragens

Modelo americano de informação

Fundação da ABI (1908)

Profissional

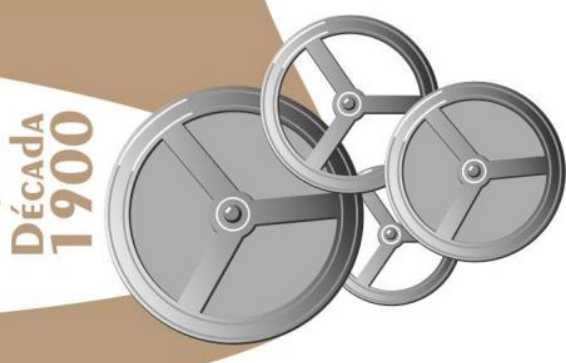

0
8

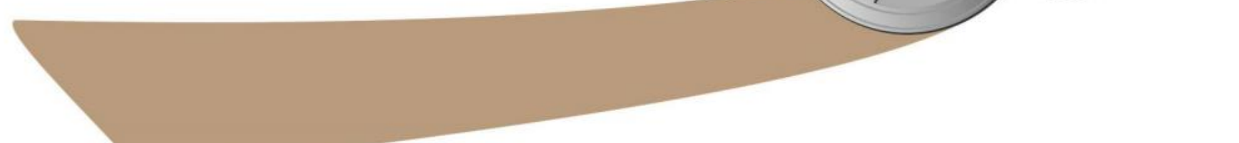

Grande

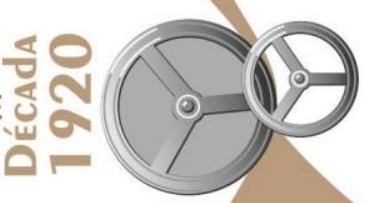

Manual de redação - Gilberto Freyre (AProvíncia-PE)

Rádio Sociedade do Rio de Janeiro (1922)

Chateaubriand compra OJornal (1924)

Irineu Marinho funda O Globo (1926)

Morre Irineu Marinho (1926)

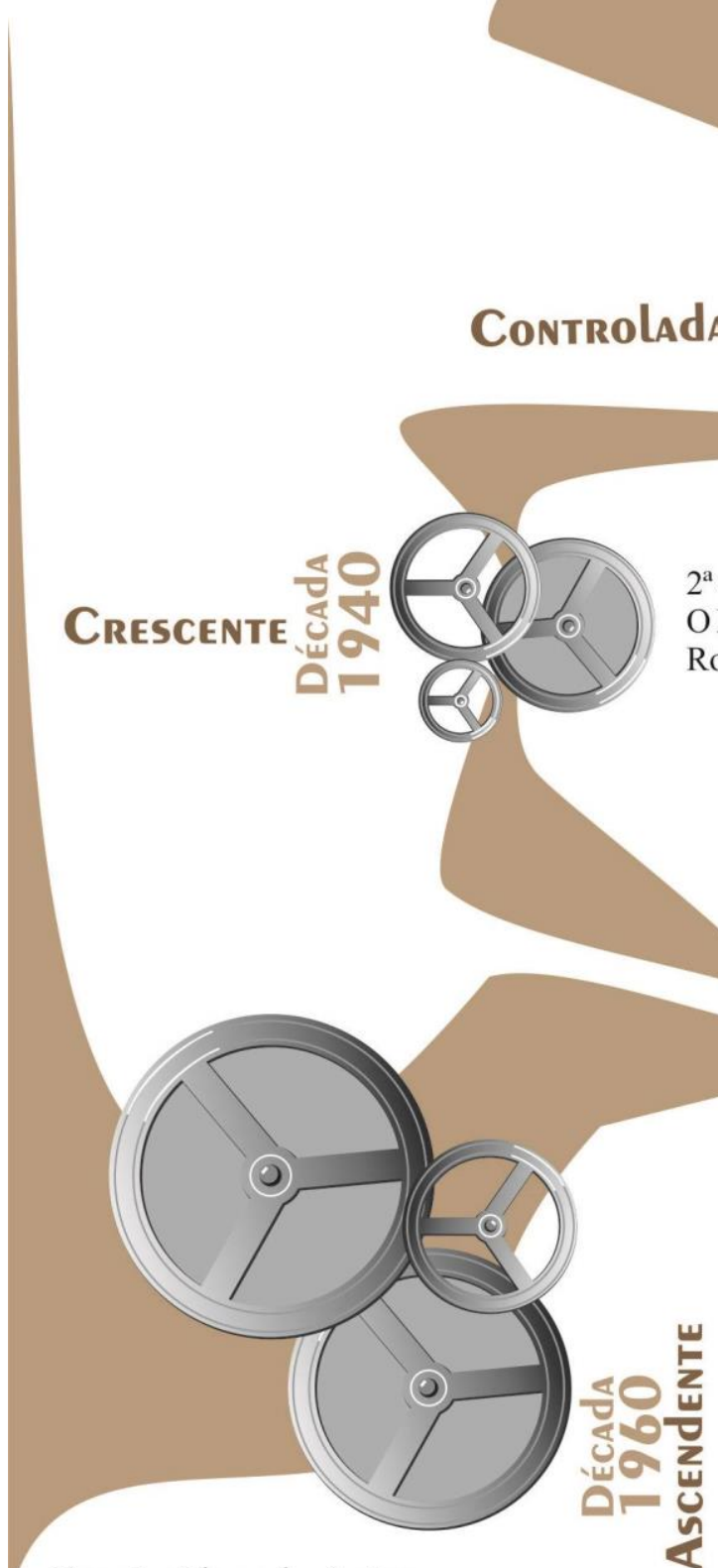

Guerra Mundial (1940-1945)

O Repórter Esso (1941)

Roberto Marinho funda a Rádio Globo do Rio de Janeiro (1944)

Chateaubriand funda a TV

Tupi de São Paulo (1950)

Chateaubriand funda a TV

Tupi do Rio de Janeiro (1951)

은 Os Diários Associados

¿ $\sum$ presentes em todo o país

Getúlio morre (1954)

Golpe militar (1964)

는 Roberto Marinho funda a TV Globo do Rio de Janeiro (1965)

CPI Time Life (1965)

Chateaubriand morre (1968)

Editado o AI-5. O regime endurece (1968)

Tronco sul de microondas da Embratel (1969)

Primeira transmissão via satélite

Jornal Nacional. Surge a Rede Globo de Televisão (1969) 
TV Globo assume a liderança na audiência TV em cor (1973)

Consolidação da rede de microondas da Embratel
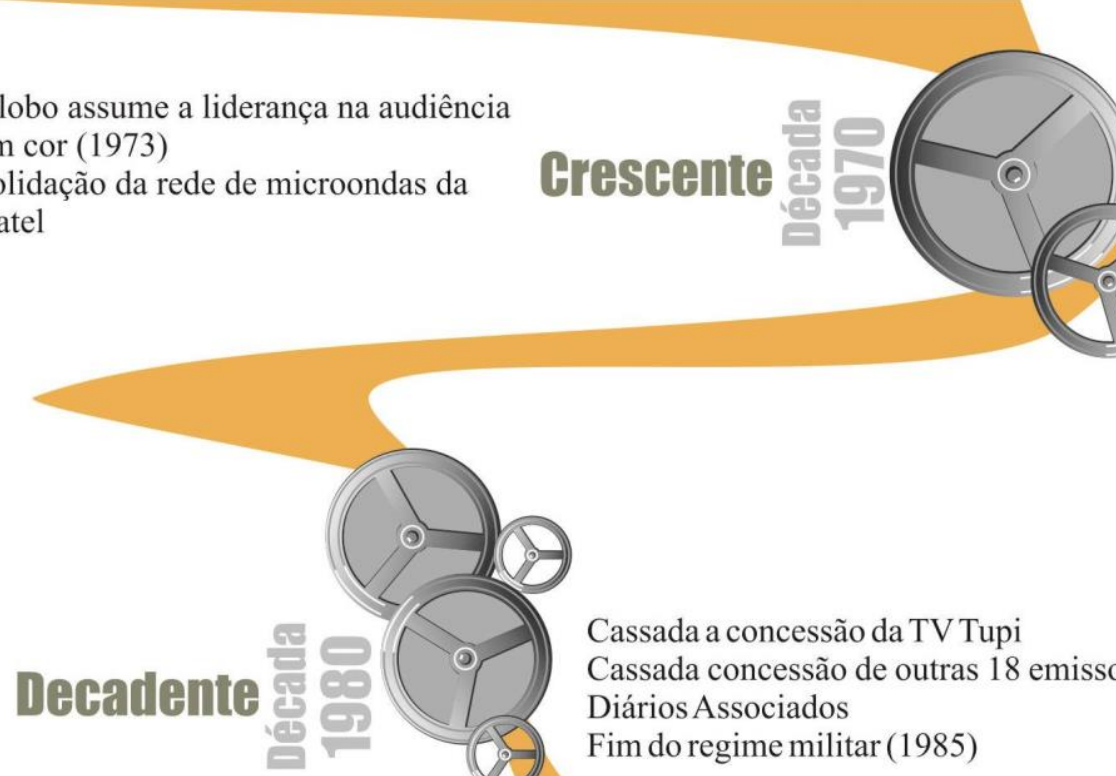

Cassada a concessão da TV Tupi

Cassada concessão de outras 18 emissoras de TV dos Diários Associados

Fim do regime militar(1985)

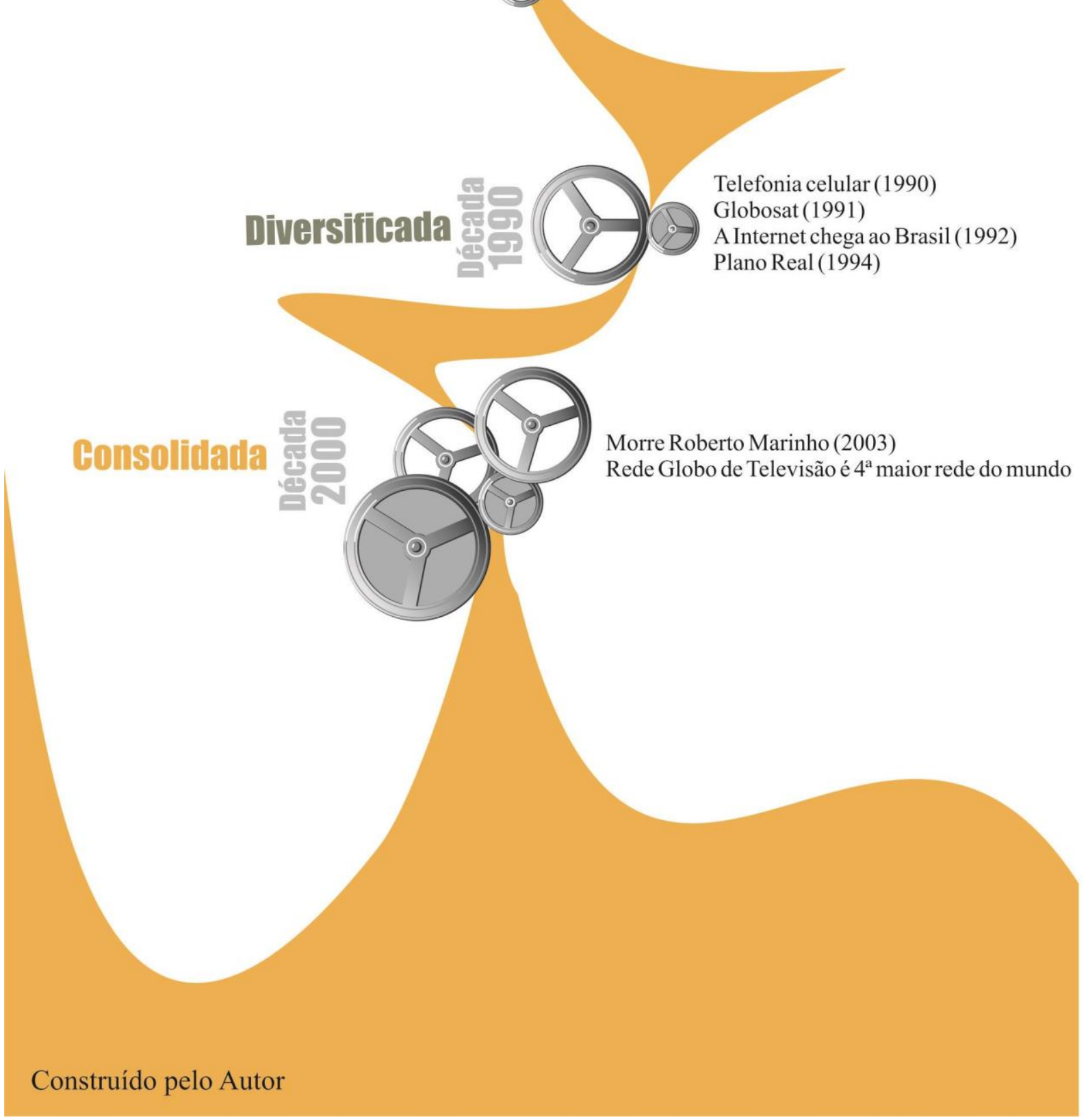

